\title{
TRITIUM-BREEDING APPLICATIONS
}

MCDONNELL DOUGLAS ASTRONAUTICS COMPANY-ST. LOUIS DIVISION DO NOT MICROFILM THIS 


\section{DISCLAIMER}

This report was prepared as an account of work sponsored by an agency of the United States Government. Neither the United States Government nor any agency Thereof, nor any of their employees, makes any warranty, express or implied, or assumes any legal liability or responsibility for the accuracy, completeness, or usefulness of any information, apparatus, product, or process disclosed, or represents that its use would not infringe privately owned rights. Reference herein to any specific commercial product, process, or service by trade name, trademark, manufacturer, or otherwise does not necessarily constitute or imply its endorsement, recommendation, or favoring by the United States Government or any agency thereof. The views and opinions of authors expressed herein do not necessarily state or reflect those of the United States Government or any agency thereof. 


\section{DISCLAIMER}

Portions of this document may be illegible in electronic image products. Images are produced from the best available original document. 


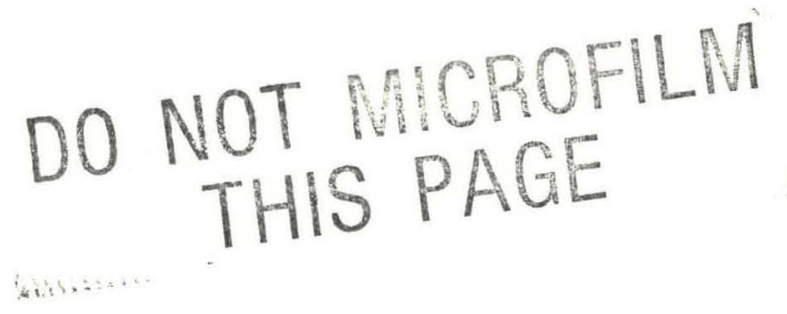

This report was prepared as an account of work sponsored by an agency of the United States Government. Neither the United States Government nor any agency thereof, nor any of their employees, makes any warranty, express or implied, or assumes any legal liability or responsibility for the accuracy, completeness, or usefulness of any information, apparatus, product, or process disclosed, or represents that its use would not infringe privately owned rights. Reference herein to any specific commercial product, process, or service by trade name, trademark, manufacturer, or otherwise, does not necessarily constitute or imply its endorsement, recommendation, or favoring by the United States Government or any agency thereof. The views and opinions of authors expressed herein do not necessarily state or reflect those of the United States Government or any agency thereof. 


$$
\text { COPY No. } 163
$$

\section{LITHIUM-BASED OXIDE CERAMICS FOR TRITIUM-BREEDING APPLICATIONS}

\section{Prepared by D. J. SUITER}

Prepared for ARGONNE NATIONAL LABORATORY Under Contract No. 31-109-38-6292

MCDONMELL DOUGLAS ASTRONAUTICS COMPANY-GT. LOUIS DIVISION

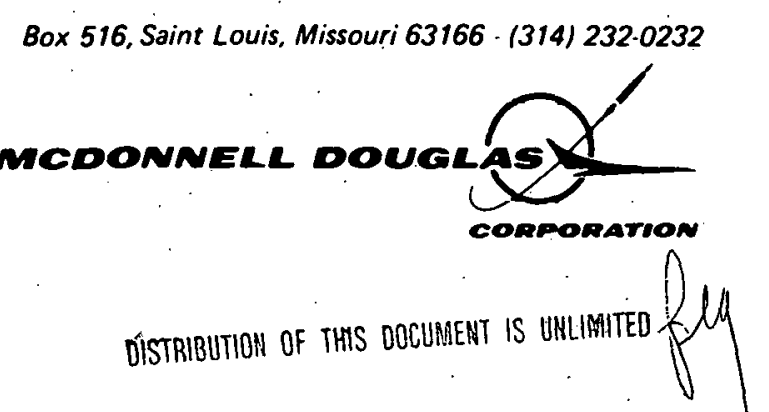



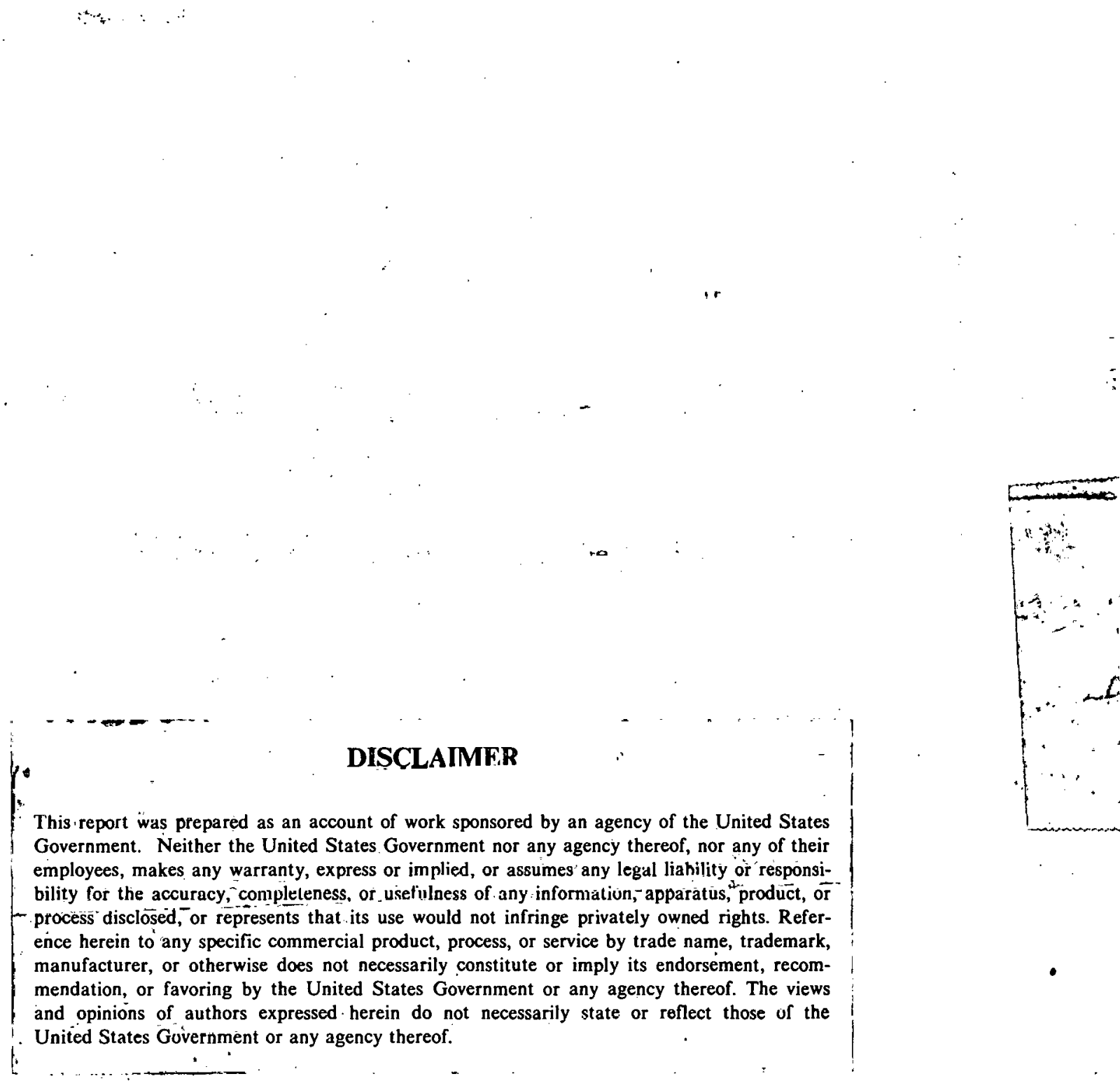


\section{ABSTRACT}

Material preparation techniques, crystallographic data, phase diagrams; metal compatibility, and thermal properties have been assembled for the lithiumbased oxide ceramics designated as potential solid tritium breeders for fusion devices. The materials discussed in this report include: $L i_{2} 0, B-L i_{5} A 10_{4}$, $\gamma-\mathrm{LiAlO}_{2}, \mathrm{Li}_{4} \mathrm{SiO}_{4}, \mathrm{Li}_{2} \mathrm{SiO}_{3}, \mathrm{Li}_{4} \mathrm{TiO}_{4}, \mathrm{Li}_{2} \mathrm{TiO}_{3}, \mathrm{Li}_{8} \mathrm{ZrO}_{6}, \mathrm{Li}_{4} \mathrm{ZrO}_{4}$, and $\mathrm{Li}_{2} \mathrm{ZrO}_{3}$. The thermal properties covered were vaporization, thermal conductivity, specific heat, and linear thermal expansion.

There has been no attempt to rank the above mentioned candidates, but rather to merely indicate points that must be considered when using the various materials as solid breeders. These encompass low lithium-atom densities, destructive phase transformations, a higher thermal expansion, low thermal conductivity, excessive vaporization at low temperatures, corrosive nature. toward metals, and difficulty in sample preparation. 


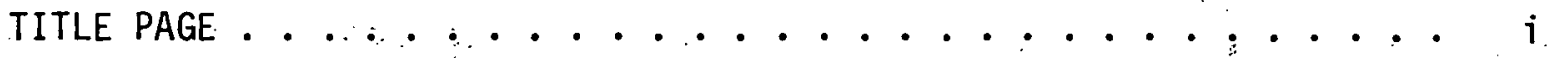

ABSTRACT . . . . . . . . . . . . . . . . . . . . . . .

LIST OF FIGURES . . . . . . . . . . . . . . . . . . . . . . vi

SUMMARY . . . . . . . . . . . . . . . . . . . . . $\mathrm{.}$. ix

1.0 INTRODUCTION : : . . . . . . . . . . . . . . . . . . . . $1-1$

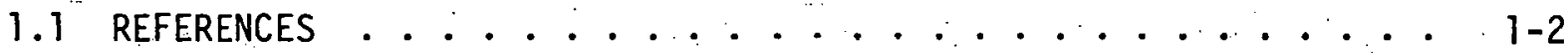

2.0 PREPARATION OF LITHIUM BASED OXIDE CERAMICS . . . . . . . . . . 2-1

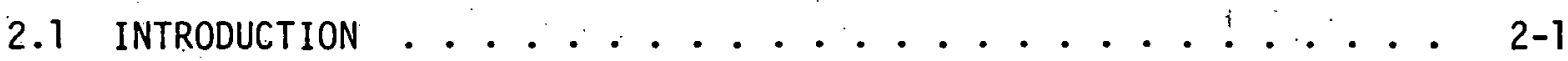

2.2 Li-0 SYSTEM . . . . . . . . . . . . . . . . . . . . . 2-1

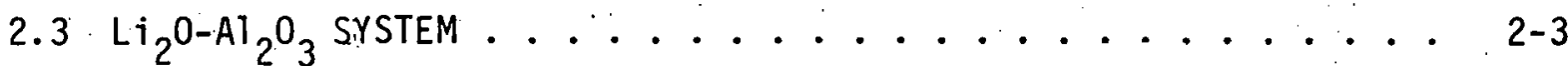

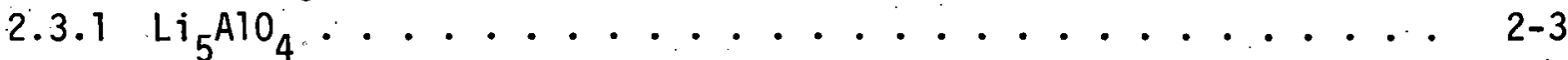

$2.3 .2 \mathrm{LiAlO}_{2}$. . . . . . . . . . . . . . . . . . . . 2-4

$2.4 \mathrm{Li}_{2} \mathrm{O}^{-\mathrm{SiO}_{2}} \mathrm{SYSTEM}$. . . . . . . . . . . . . . . . . $2-6$

$2.4 .1 \mathrm{Li}_{4} \mathrm{SiO}_{4}$. . . . . . . . . . . . . . . . . . . . 2-6

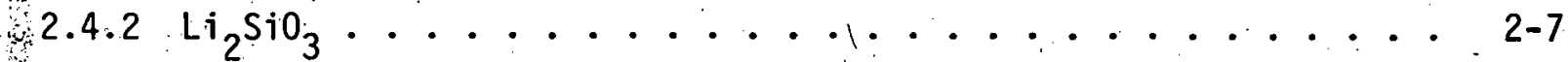

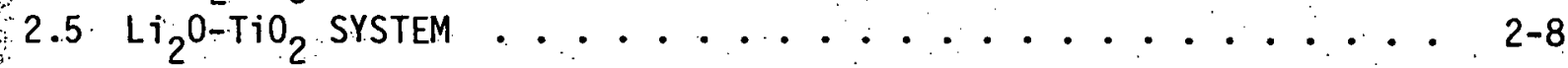

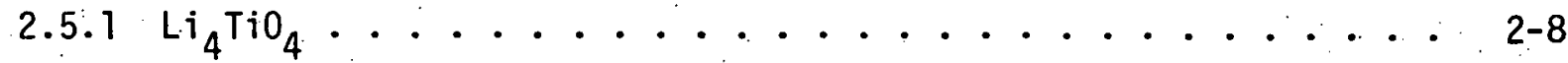

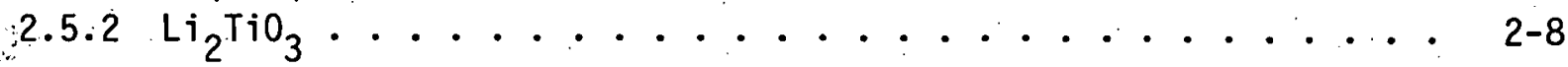

$2.6 \mathrm{Li}_{2} \mathrm{O}-\mathrm{ZrO}_{2} \mathrm{SYSTEM}$. . . . . . . . . . . . . . . . . . . . $2-9$

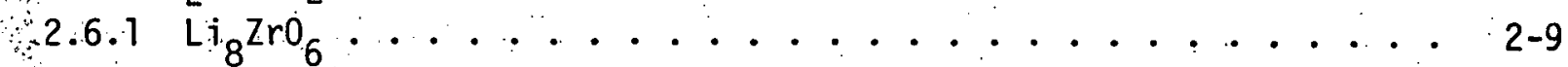

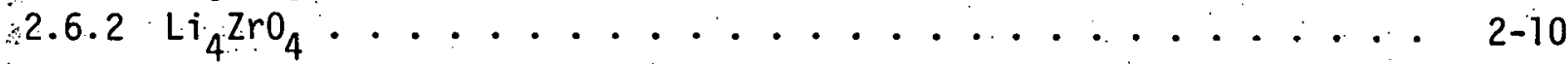

2.6.3 $\mathrm{Li}_{2} \mathrm{ZrO}_{3}$. . . . . . . . . . . . . . . . . . . 2-10

2.7 REFERENCES . . . . . ................. 2-11

3.0 CRYSTALLINE PROPERTIES . . . . . . . . . . . . . . . . .

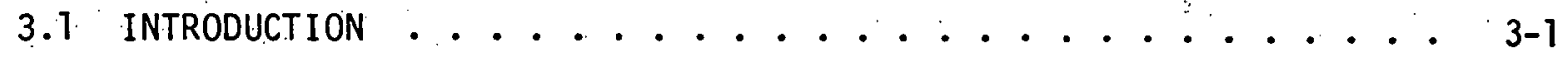

3.2 LI-O SYSTEM . . . . . . . . . . . . . . . . . . . . 3-1

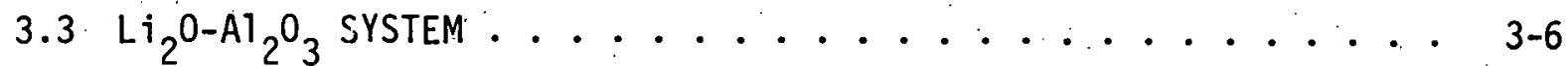

$3.4 \mathrm{Li}_{2}{ }^{\mathrm{O}-\mathrm{SiO}_{2}} \mathrm{SYSTEM}_{3.5}$. . . . . . . . . . . . . . . . . . . $3-14$

$3.5 \mathrm{Li}_{2}{\mathrm{O}-\mathrm{TiO}_{2} \text { SYSTEM }}_{3}$. . . . . . . . . . . . . . . . . $3-21$

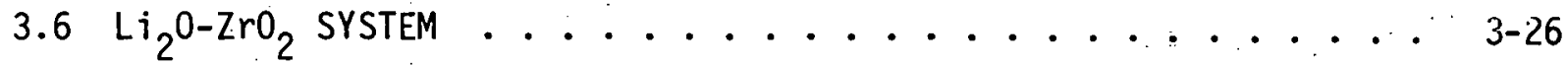

3.7 REFERENCES ............................. 34 
TABLE OF CONTENTS (CONT'D.)

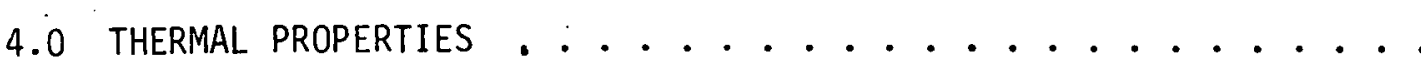

PAGE

4.1 INTRODUCTION ...............................

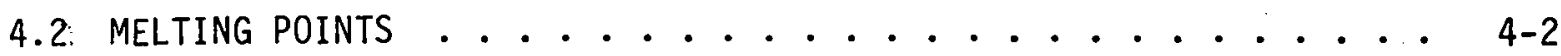

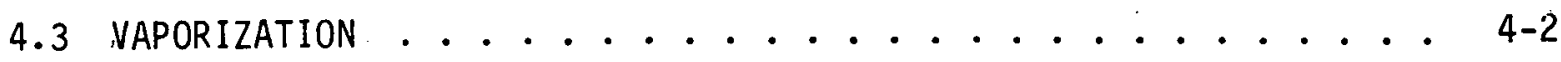

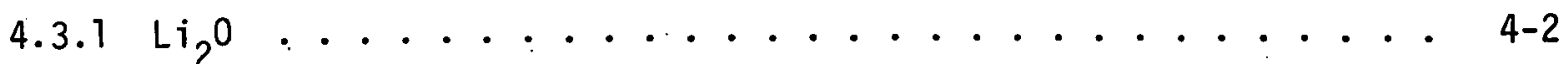

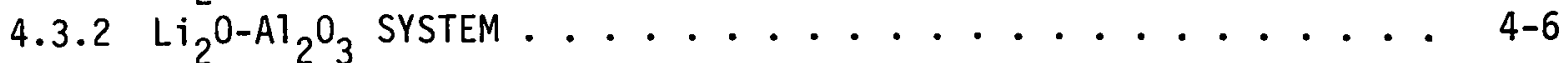

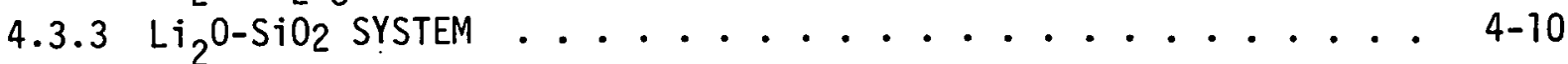

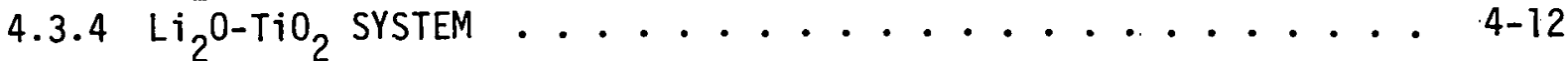

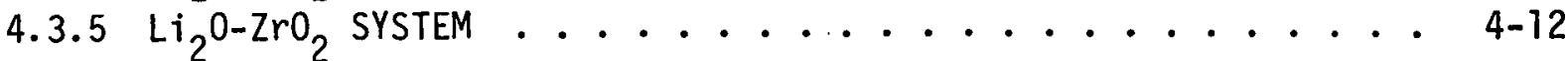

$4.3 .6 \mathrm{Li}_{2} 0$ - METAL OXIDE SYSTEMS .................. 4-13

4.4 THERMAL CONDUCTIVITY .................... 4-15

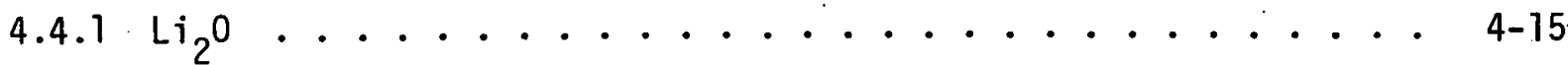

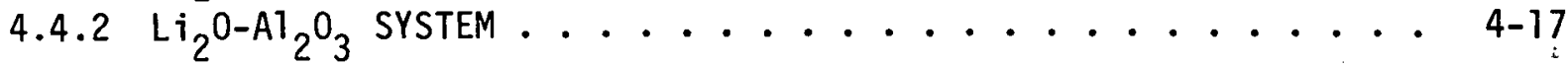

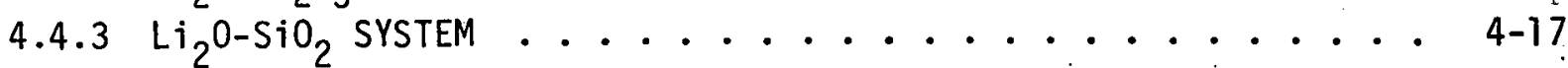

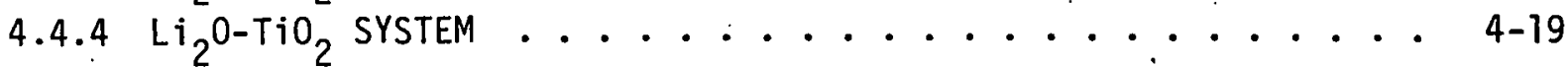

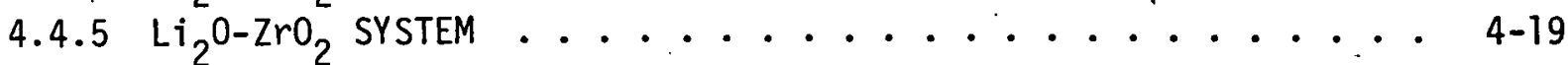

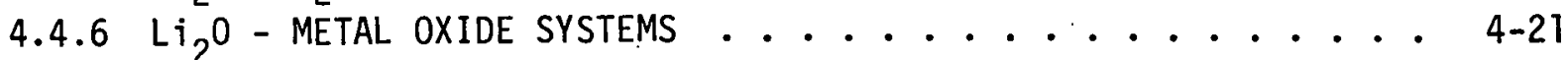

4.5 SPECIFIC HEAT . . . . . . . . . . . . . . . 4 4-22

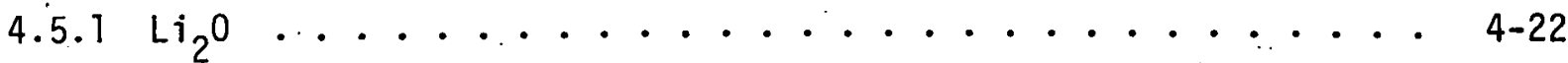

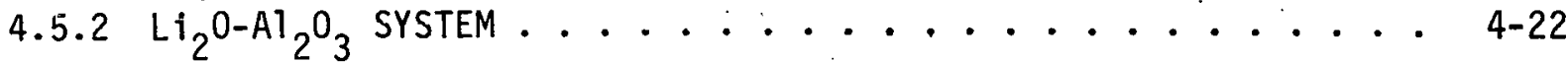

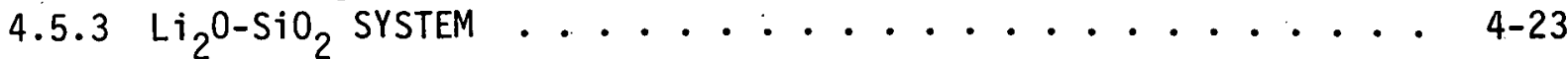

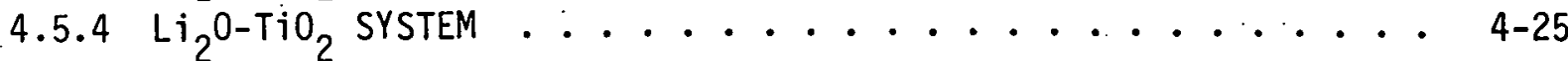

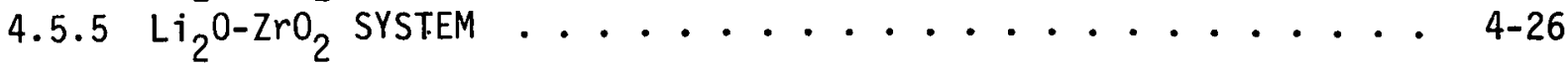

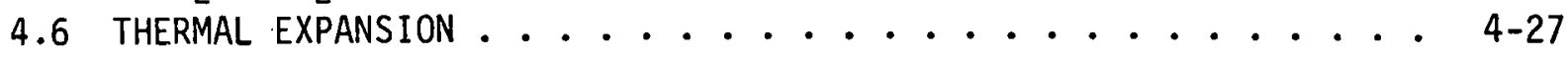

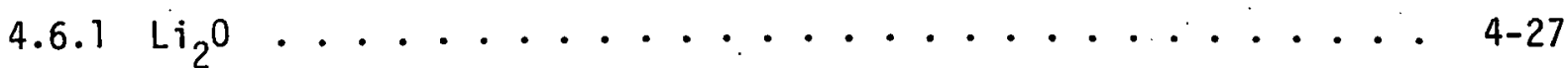

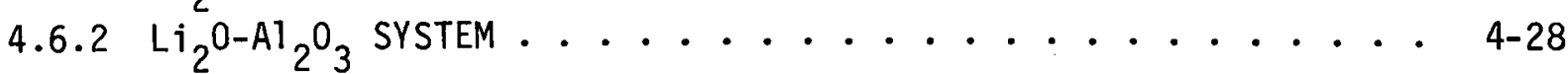

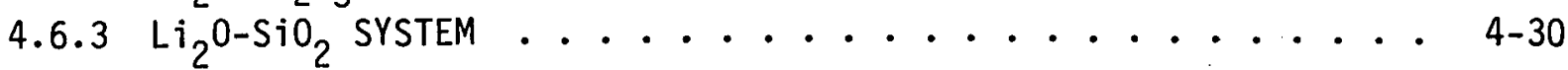

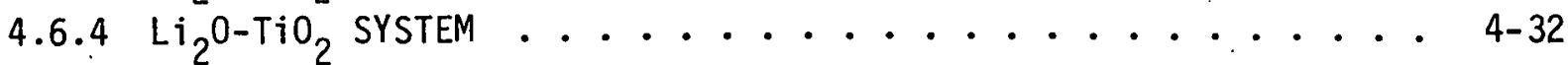

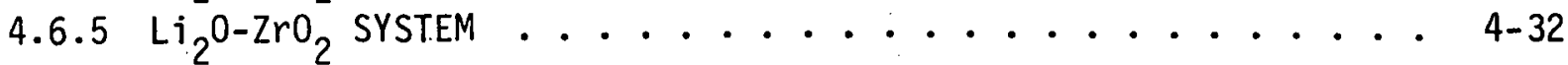

$4.6 .6 \mathrm{Li}_{2} 0$ - METAL OXIDE SYSTEMS .............. 4-33

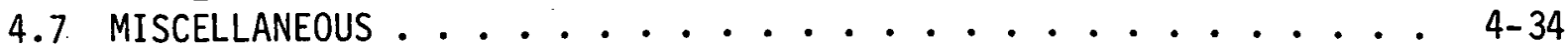

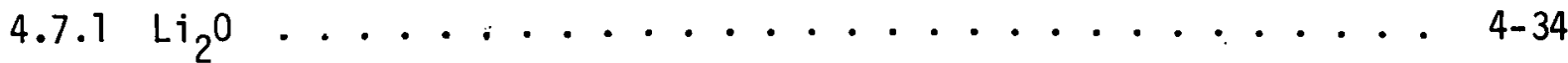

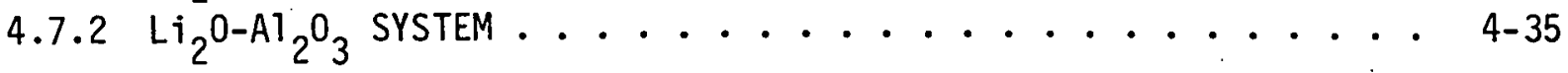


TABLE OF CONTENTS (CONT'D.)

PAGE

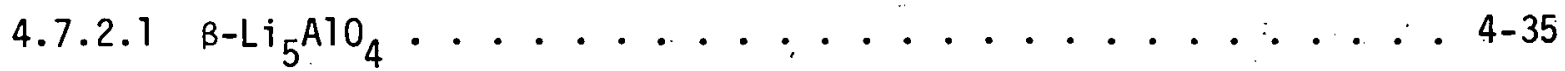

$4.7 .2 .2 \gamma-\mathrm{LiAlO}_{2} \ldots \ldots . \ldots . . . . . . . . . .44-35$

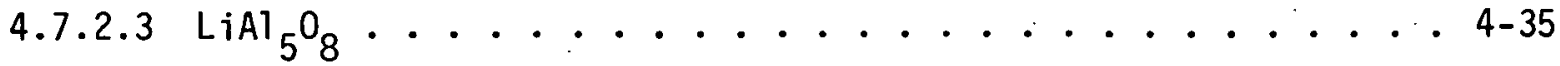

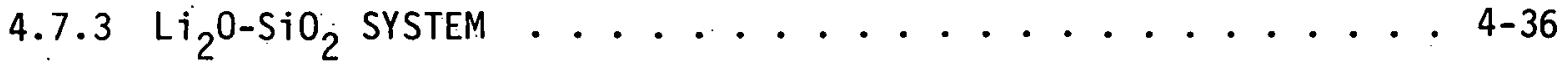

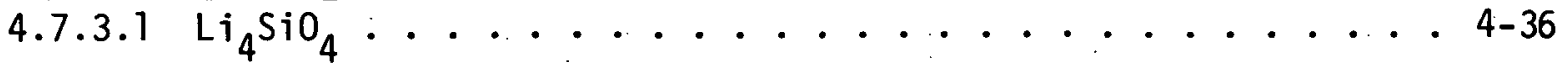

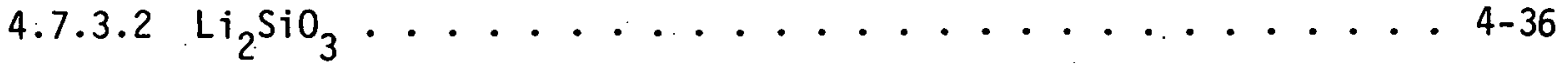

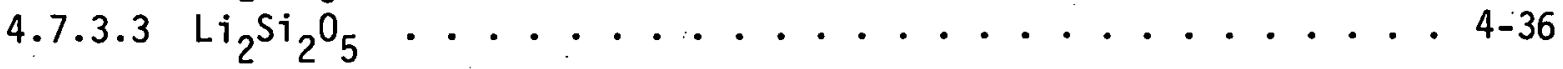

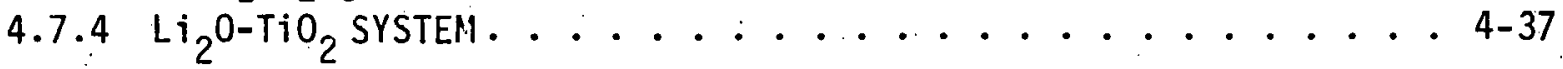

$4.7 .5 \mathrm{Li}_{2} \mathrm{O}-\mathrm{ZrO}_{2}$ SYSTEM $\ldots \ldots . . . . . . . . . .4-38$

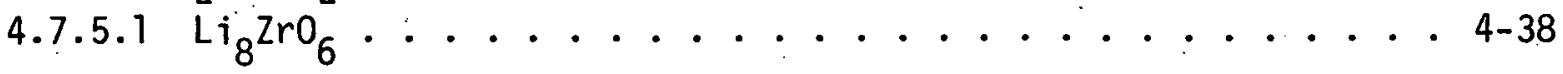

$4.7 .5 .2 \mathrm{Li}_{4} \mathrm{ZrO}_{4} \ldots \ldots . \ldots . . . . . . . .448$

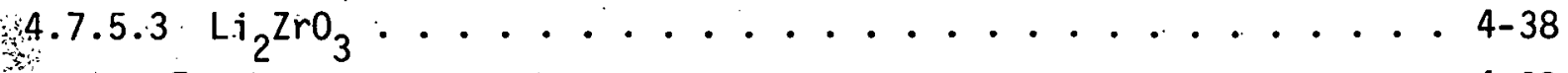

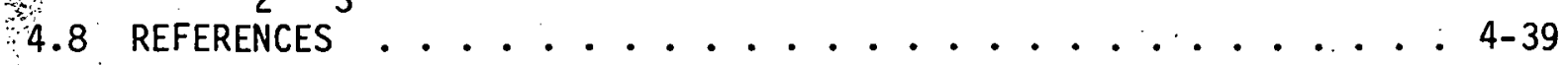

5.0 COMPATIBILITY OF LITHIUM CERAMICS AND METALS ...... . . .

5.1 INTRODUCTION ......................... . . . . .

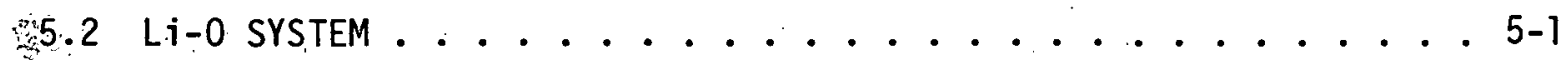

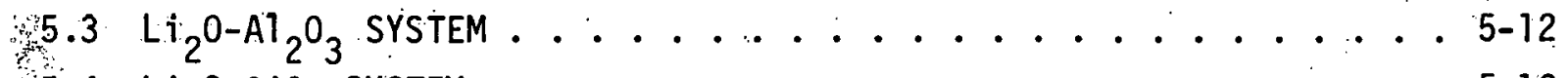

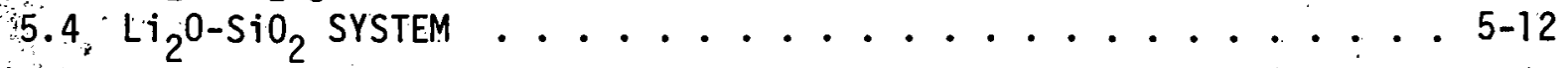

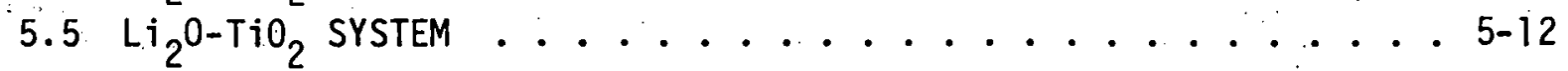

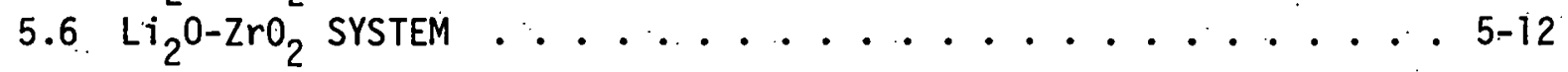

5.7 REFERENCES $\ldots \ldots \ldots \ldots \ldots . \ldots \ldots$ 


\section{LIST OF FIGURES}

FIGURE NO.

TITLE

PAGE

3.2 .1

PARTIAL PHASE DIAGRAM OF THE SYSTEM Li ${ }_{2} \mathrm{CO}_{3}-\mathrm{Li}_{2}{ }^{\mathrm{O}}$

ACCORDING TO PAPIN, ET AL. ........ 3-2

3.2 .2

PARTIAL PHASE DIAGRAM OF THE SYSTEM Li ${ }_{2} \mathrm{CO}_{3}-\mathrm{Li}_{2}{ }^{\mathrm{O}}$

ACCORDING TO SMIRNOV, ET AL. ......... 3-3

3.2 .3

PROJECTED PHASE DIAGRAM OF THE SYSTEM LiOH-Li ${ }_{2}{ }^{0} \ldots$. 3-4

3.2 .4

CRYSTALLOGRAPHIC DATA FOR LITHIUM OXIDE $\ldots \ldots$

3.3 .1

PARTIAL PHASE DIAGRAM OF THE SYSTEM Li ${ }_{2} \mathrm{O}^{\mathrm{A} \mathrm{Al}_{2} \mathrm{O}_{3}} \cdot \ldots$. . 3-6

3.3 .2

CRYSTALLOGRAPHIC DATA FOR LITHIUM META-ALUMINATE . . . 3-8

3.3 .3

CRYSTALLOGRAPHIC DATA FOR TETRAOXO-LITHIUM-ALUMINATE . 3-12

3.4 .1

PARTIAL PHASE DIAGRAM OF THE SYSTEM $\mathrm{Li}_{2} \mathrm{O}-\mathrm{SiO}_{2} \ldots \ldots$

3.4 .2

CRYSTALLOGRAPHIC DATA FOR LITHIUM ORTHOSILICATE . . 3-17

3.4 .3

CRYSTALLOGRAPHIC DATA FOR LITHIUM METASILICATE . . . 3-19

3.5 .1

PARTIAL PHASE DIAGRAM OF THE SYSTEM Li $\mathrm{L}_{2} \mathrm{O}-\mathrm{TiO}_{2} \cdot \ldots$. . 3-22

3.5 .2

CRYSTALLOGRAPHIC DATA FOR LITHIUM ORTHOTITANATE . . . 3-23

3.5 .3

CRYSTALLOGRAPHIC DATA FOR LITHIUM METATITANATE . . . 3-25

3.6 .1

CRYSTALLOGRAPHIC DATA FOR OCTALITHIUM ZIRCONATE $\ldots$. . 3-27

3.6 .2

CRYSTALLOGRAPHIC DATA FOR LITHIUM ORTHOŻIRCONATE . . 3 3-30

3.6 .3

CRYSTALLOGRAPH̃IC DATA FOR LITHIUM METAZIRCONATE . . . 3-32

4.2 .1

MELTING POINTS OF SOLID BREEDER CANDIDATES . . . . 4-3

4.3 .1 .1

Li PARTIAL PRESSURE OVER Li $i_{2}^{3} 0$ IN A Pt KNUDSEN CELL . * 4-4

4.3 .1 .2

VARIOUS PARTIAL PRESSURES OVER $L i_{2} O$ IN A Pt KNUDSEN

CELL ..................... 4-4

4.3 .1 .3

$\mathrm{Li}_{2} 0$ PARTIAL PRESSURE OVER Li ${ }_{2} 0$ IN A Pt KNUDSEN CELL • 4-5

4.3 .1 .4

Li PARTIAL PRESSURE OVER L $i_{2} 0$ IN KNUDSEN CELLS OF VARIOUS METALS ..................... 4-6

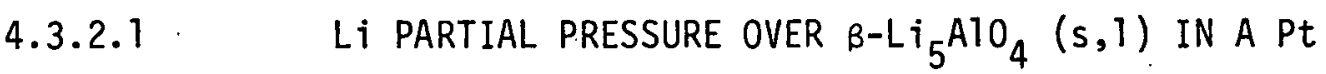
KNUDSEN CELL .................. 4-7 
$\therefore$ LIST OF FIGURES (CONT'D.)

FIGURE NO.

TITLE

PAGE

4.3 .2 .2

VARIOUS PARTIAL PRESSURES OVER $\gamma$-LiAlO 2 IN A Pt KUNDSEN CELL . . . . . . . . . . . 4-8

4.3.2.3 Li PARTIAL PRESSURES OVER $\gamma$-LiATO 2 IN A PL KUNDSEN CELL ................... 4- . . .

4.3.2.4 Li PARTIAL PRESSURES OVER $\gamma$-LiA10 2 IN KNUDSEN CELLS OF VARIOUS METALS ............... 4-9

4.3 .2 .5

4.3 .3 .1

4.3 .5 .1

$4 \cdot 3 \cdot 6.1$

.

4.3 .6 .2

PARTIAL PRESSURES OVER LiA1 ${ }_{5}{ }_{8}$ IN A Pt KNUDSEN CELL • 4-10 PARTIAL PRESSURES OVER $\mathrm{Li}_{2} \mathrm{SiO}_{3}$ IN A Pt KNUDSEN CELL • 4-11 Li PARTIAL PRESSURE OVER THE $\mathrm{Li}_{2} \mathrm{O}^{\mathrm{O}} \mathrm{ZrO}_{2}$ SYSTEM. IN Pt KNUDSEN CELLS .......................... 4-

Li PARTIAL PRESSURE OVER SOLID BREEDER CANDIDATES IN Pt KNUDSEN CELLS . . ................... 4- . . . .

Li PARTIAL PRESSURE OVER CORROSION PRODUCTS FOUND DURING $L i_{2}$ O/METAL COMPATIBILITY EXPERIMENTS $\cdots$ 4-14 THERMAL CONDUCTIVITY OF CRYSTALLINE Li ${ }_{2} 0 \ldots$. . 4-16 THERMAL CONDUCTIVITY OF CRYSTALLINE LiA10 ${ }_{2} \cdots$. . . 4-18. THERMAL CONDUCTIVITY OF CRYSTALLINE $\mathrm{Li}_{4} \mathrm{SiO}_{4} \ldots \ldots$ 4-18 4.4 .4 .1 THERMAL CONDUCTIVITY OF CRYSTALLINE $\mathrm{Li}_{2} \mathrm{TiO}_{3} \cdots \cdots$ 4-20 4.4.5.1 THERMAL CONDUCTIVITY OF CRYSTALLINE $\mathrm{Li}_{2} \mathrm{ZrO}_{3} \cdot \ldots$. 4-20 4.4.6.1

4.5.1.1 COMPARISON OF THERMAL CONDUCTIVITY VALUES FOR VARIOUS SOLID BREEDER CANDIDATES ........... 4-... 4-21

4.5.2.1 SPECIFIC HEAT OF $\mathrm{Li}_{2}$ 4-23

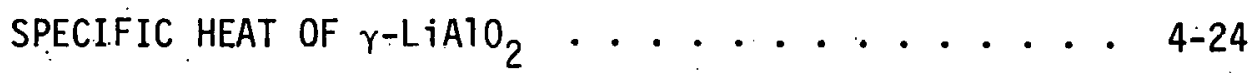
4.5.3.1 4.5.4.1 SPECIFIC HEAT OF COMPOUNDS IN THE $\mathrm{Li}_{2} \mathrm{O}^{\mathrm{S}} \mathrm{SiO}_{2}$ SYSTEM $\cdots 4-25$ SPECIFIC HEAT OF $\mathrm{Li}_{2} \mathrm{TiO}_{3} \ldots \ldots . . . . . . . .4-26$ 4.5.5.1 SPECIFIC HEAT OF $\mathrm{Li}_{2} \mathrm{ZrO}_{3}$. 4-27 
LIST OF FIGURES (CONT'D.)

FIGURE NO.

TITLE

PAGE

4.6.1.1

LINEAR THERMAL EXPANSION OF SINGLE CRYSTAL AND

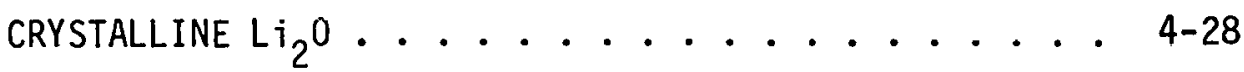

4.6.2.1

LINEAR THERMAL EXPANSION OF CRYSTALLINE $\gamma-\mathrm{LiATO}_{2}$ AND $\mathrm{LiAl}_{5} \mathrm{O}_{8}$. . . . . . . . . . . . . . . . 4-29

4.6.3.1

LINEAR THERMAL EXPANSION OF COMPOUNDS IN THE $\mathrm{Li}_{2} \mathrm{O}-\mathrm{SiO}_{2}$

4.6.4.1

LINEAR THERMAL EXPANSION OF CRYSTALLINE $\mathrm{Li}_{2} \mathrm{TiO}_{3} \cdots$ 4-32

4.6.5.1

LINEAR THERMAL EXPANSION OF CRYSTALLINE $\mathrm{Li}_{2} \mathrm{ZrO}_{3} \cdot \cdots \quad 4-33$

$4 \cdot 6.6 .1$

COMPARISON. OF LINEAR THERMAL EXPANSION OF SOLID

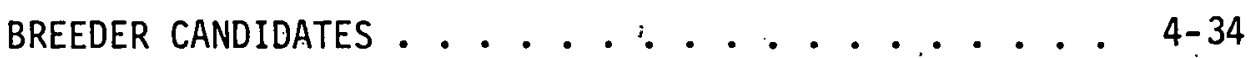

5.2 .1

LITHIA/METAL COMPATIBILITY RESULTS . . . . . . 5-2

5.2 .2

RATE OF OXIDE SCALE FORMATION ON METAL/Li $i_{2} 0$ REACTION COUPLES IN A $10^{-5}$ TORR ENVIRONMENT . . . . . . 5-9

5.2 .3

RATE OF OXIDE SCALE FORMATION ON METAL/Li ${ }_{2} 0$ REACTION COUPLES IN A STATIC He ENVIRONMENT . . . . . . . 5-10

5.2 .4 CHEMICAL COMPOSITIONS OF METAL REACTION COUPLE SPECIMENS 
The physical preparation of the candidate powders has not proven to be an insurmountable task in as much as the majority can be made using simple solid state reaction techniques. $\mathrm{Li}_{2} \mathrm{O}$ has presented the most problems from a powder preparation standpoint with its tendency to absorb $\mathrm{CO}_{2}$ and $\mathrm{H}_{2} \mathrm{O}$, its volatility and reactivity with container materials at high temperatures. For $\mathrm{Li}_{2} \mathrm{O}$, as well as the others, great care has to be taken to achieve relatively small batches of high purity, single phase powders. In addition, these lithium based oxides have displayed a strong tendency to absorb chlorine compounds from the air, containers, or even in a controlled atmosphere glove box. This presents further difficulties in powder production, storage, and specimen fabrication to insure low levels of $\mathrm{Cl}$, to prevent stress corrosion during irradiation. Test sample fabrication with all materials has been accomplished once good quality powders were obtained. If, for example, test pellets were required to possess a final $\approx 1$ un grain (crystallite) size or high density, then hot pressing has been the solution with little or no surface contamination. If the grain size or density requirement were removed, then all of the powders can be cold pressed and sintered, still paying special regard to: 1) the $\mathrm{P}_{0_{2}}$ of the sintering atmosphere to retard Li volatilization, 2) the "dryness" is of the sintering atmosphere so as to minimize (if not eliminate) $\mathrm{CO}_{2}$ and $\mathrm{H}_{2} \mathrm{O}$ absorption, and 3) the interaction of the solid breeder with its setter plate during sintering. Cold pressing and firing to high densities has been difficult due to the lack of work on the use of additives to retard grain growth.

With the exception of the $\mathrm{Li}_{2} \mathrm{O}^{-} \mathrm{ZrO}_{2}$ system, at least partial phase diagrams exist for the remaining candidate material systems. Such diagrams are essential in predicting the results of any deviations from stoichiometry such as might occur during irradiation with Li burnup. In addition, any crystallographic transformations must be noted and investigated to determine whether or not they are destructive transformations and if they lie in the temperature range of solid breeder operation. This information can be invaluable in assessing solid breeders as shown by Dr. Hollenberg's work illustrating that the phase transformation in $\mathrm{Li}_{4} \mathrm{SiO}_{4}$, previously thought to be destructive thus reducing its chänces from a solid breeder consideration, was only displacive in nature and solid pellets or rods would hold together and not crack as the transformation temperature was surpassed. Very little crystallographic 
information exists for the compounds $\mathrm{Li}_{8} \mathrm{ZrO}_{6}$ and $\mathrm{Li}_{4} \mathrm{ZrO}_{4}$ and almost none concerning the relationships (solid solution's, etc.) that are found within the $\mathrm{Li}_{2} \mathrm{O}-\mathrm{ZrO}_{2}$ system.

Some thermal property data have been generated for the majority of solid breeders. As a leading candidate, $\mathrm{Li}_{2} \mathrm{O}$ has received the most attention with extensive work being done on specific heat, vaporization rates and products, effect of porosity on thermal conductivity and on linear expansion coefficients. The others, with the exception of $\mathrm{Li}_{8} \mathrm{ZrO}_{6}$ and $\mathrm{Li}_{4} \mathrm{ZrO}_{4}$, have received some interest for basic property data. While thermal conductivity measurements exist for the remaining ones with the exception of $\mathrm{Li}_{8} \mathrm{ZrO}_{6}$ and $\mathrm{Li}_{4} \mathrm{ZrO}_{4}$, they do not address the porosity dependence, effect of grain size or the effects:of atmospheric conditions on the thermal conductivity. This kind of data will be needed to help predict the solid breeder's thermal performance in actual operation. Vaporization rates for $\mathrm{Li}_{4} \mathrm{SiO}_{4}$ have not been generated and the effect of moisture in the atmosphere during vaporization has only been "seen" in $\mathrm{Li}_{2} 0$. Thermal conductivity, specific heat, and thermal expansion values are non-existant for $\mathrm{Li}_{8} \mathrm{ZrO}_{6}$ and $\mathrm{Li}_{4} \mathrm{ZrO}_{4}$ and are needed to properly evaluate these materials.

Most of the metal compatibility experiments have centered on $\mathrm{Li}_{2} \mathrm{O}$ because it is regarded as the most corrosive of all the materials. Nickel and nickelbased alloys performed the best, regardless of environment or which solid breeder material was used. Data for the majority of remaining candidates are limited or do not exist. Some of the studies have postulated that the $\mathrm{Li}_{2} \mathrm{O}$ itself is not the problem but that of $\mathrm{LiOH}$, and that if the $\mathrm{LiOH}$ concentration can be minimized or eliminated, then $L_{2} i_{2}$ compatibility problem will be substantially reduced.

This report has dwelt on available data for nonirradiated speciments, but as these materials are assessed the effects of irradiation (tritium release, dimensional changes, phase transformations, nonstoichiometry, etc.) will need to be taken into account. 


\subsection{INTRODUCTION}

Fusion power reactors that utilize the D-T fuel cycle will be required to breed and recover tritium in quantities at least equal to its composition. The most cost-effective approach involves the transmutation of lithium atoms by neutrons to form helium and the needed tritium. Debate has centered on whether the utilized form of the lithium should be a liquid metal, liquid salt, metal alloy, or oxide-based ceramic. The leading candidates appear to be liquid lithium or a lithium alloy, which have the advantage of being both a tritium breeder and a coolant in the first wall blanket. However, the liquid metals are highly flammable and corrosive and present serious safety concerns if leaks develop. The solid lithium-based oxide ceramics are being investigated as an alternate to the liquid metals.

A number of blanket and shield design studies $(1-4)$ that investigated the use of solid breeders have identified $\mathrm{Li}_{2} \mathrm{O}, \mathrm{\gamma}-\mathrm{LiAlO}_{2}, \mathrm{Li}_{4} \mathrm{SiO}_{4}, \mathrm{Li}_{2} \mathrm{SiO}_{3}$, $\mathrm{Li}_{2} \mathrm{TiO}_{3}$, and $\mathrm{Li}_{2} \mathrm{ZrO}_{3}$ as candidate materials having the capability of achieving the desired net breeding ratios within the first wall blanket. Currently $\mathrm{Li}_{2} \mathrm{O}$, which is considered the leading solid breeding oxide since it has a Li atom fraction greater than liquid $L i$ and does not require a neutron multiplier to increase the tritium breeding ratio (TBR) to $\geq 1$. 0 ther compounds that are also of interest fall within the following four systems: $\mathrm{Li}_{2} \mathrm{O}-\mathrm{Al}_{2} \mathrm{O}_{3}$, $\mathrm{Li}_{2}{ }^{\mathrm{O}-\mathrm{SiO}_{2}}, \mathrm{Li}_{2} \mathrm{O}^{-\mathrm{TiO}_{2}}$, and $\mathrm{Li}_{2} \mathrm{O}-\mathrm{ZrO}_{2}$.

In order to make valid decisions on these compounds, material property data must be available. The focus of this effort is to begin a centralized data base that will concentrate on material preparation techniques, crystallographic data, phase diagrams, thermal conductivity, specific heat, thermal expansion, and metal compatibility. Also necessary for comparisons would be tritium diffusion coefficients but while there has been an abundance of tritium diffusion data from irradiation experiments involving the lithium-based oxide ceramics, meaningful interpretations have been difficult to derive. Okula and $S z \mathrm{e}^{(5)}$ reviewed the bulk of the irradiation experiments involving solid breeders through 1979 and reported widely scattered data at low temperatures and low fluence conditions. At present, irradiation experiments are underway or being planned that will produce more definitive results at 
the higher, more blanket-like operating temperatures and fluences. As a result of the uncertainties that exist in the present, available tritium diffusion data for solid breeders, it will not be covered in this report.

\subsection{REFERENCES}

1. Powell, J. R. Benenati, R., Bezler, R., Fillo, J., Lazareth, 0., Majeski, S., Sheehan, T. V., "Preliminary Reference Design of Fusion Reactor Blanket Exhibiting Very Low Residual Radioactivity," Brookhaven National Laboratory, BNL-19565 (1974).

2. Badger, B., Conn, R. W., Kulcinski, G. L., et al., "UWMAK-II, A Conceptual Tokamak Power Reactor Design,"! University of Wisconsin, UWFDM-112 (1975).

3. Sako, K., Ohta, M., Seki, Y., Yamato, H., Hiraoka, T., Tanaka, K. Asami, M., and Mori, S., "Conceptual Design of a Gas Cooled Tokamak Reactor," Japanese Atomic Energy Research Institute, JAERI-M-5502 (1973).

4. Baker, C. C., et al., "STARFIRE, A Commercial. Tokamak Fusion Power Plant Study," Argonne National Laboratory, ANL/FPP-80-1 (1980).

5. Okula, K., and Sze D. K., "Tritium Recovery from Solid Breeders: Implications of the Existing Uata", University of Wisconsin, UWFDM-351 (1980). 


\subsection{PREPARATION OF LITHIUM BASED COMPONENTS}

\subsection{INTRODUCTION}

Since the selected solid breeder material must not only meet phase purity requirements but also grain (or crystallite) size and impurity limitations, it is important to know what previous avenues have been followed and their results. Attempts/successes at producing the Li-based oxides, by methods in the 1 aboratory are discussed below.

\subsection{Li-O SYSTEM}

\section{$2.2 .1 \mathrm{Li}_{2} \mathrm{O}$}

Lithium oxide $\left(\mathrm{Li}_{2} \mathrm{O}\right)$ can be usually obtained by following any of four reactions:

$\mathrm{Li}+\mathrm{O}_{2} \rightarrow \mathrm{Li}_{2} \mathrm{O}$

$2 \mathrm{Li}_{2} \mathrm{O}_{2}+2 \mathrm{Li}_{2} \mathrm{O}+\mathrm{O}_{2} \uparrow$

$2 \mathrm{LiOH} \rightarrow \mathrm{Li}_{2} \mathrm{O}+\mathrm{H}_{2} \mathrm{O} \uparrow$

$\mathrm{Li}_{2} \mathrm{CO}_{3} \rightarrow \mathrm{Li}_{2} \mathrm{O}+\mathrm{CO}_{2} \uparrow$

Pierron ${ }^{(1)}$ reported dissolving lịthium metal (Li) in liquid ammonia and then injecting oxygen into the blue solution until it turned clear. The solution was then evaportated to dryness, leaving a residue of 1 ithium peroxide $\left(\mathrm{Li}_{2} \mathrm{O}_{2}\right)$ and $\mathrm{Li}_{2} \mathrm{O}$. Subsequent heating to $300^{\circ} \mathrm{C}$ for several hours decomposed the peroxide, leaving an $\mathrm{Li}_{2} \mathrm{O}$ sample. No purity data were given for the sample.

Equations (3) and (4) are the more conventional routes taken to produce $\mathrm{Li}_{2} 0$, and they can be performed in air, vacuum, or inert atmosphere with varying degrees of success. Van Arkel et al. (2) decomposed 1 ithium hydroxide (LiOH) in a platinum (Pt) container $01000^{\circ} \mathrm{C}$ for several hours in vacuum, and then initiated melting point determination for $\mathrm{Li}_{2} \mathrm{O}$. No impurities were listed 
and no interaction with the Pt crucible was reported. The Joint Committee on Powder Diffraction Standards (JCPDS) card \#12-254 stated that the $\mathrm{Li}_{2} \mathrm{O}$ used to produce the indexed pattern had been derived by decomposing $\mathrm{LiOH}$ a $650^{\circ} \mathrm{C}$ in a $\mathrm{Ag}$ boat in an inert environment protected from atmospheric $\mathrm{CO}_{2}$ and $\mathrm{H}_{2} \mathrm{O}$. The final product contained $0.1-1.0 \mathrm{wt} . \%$ calcium (Ca), 0.01-0.1 wt.\% sodium $(\mathrm{Na}), 0.001-0.01$ wt.\% al uminum (Al), silicon (Si), and vanadium $(V)$, but no particle size was reported.

Brewer and Margrave ${ }^{(3)}$ used the thermal decomposition of lithium carbonate $\left(\mathrm{Li}_{2} \mathrm{CO}_{3}\right)$ to produce the $\mathrm{Li}_{2} \mathrm{O}$ for their melting point experiments. They decomposed the carbonate in a $P$ t crucible under high vacuum by gradually heating to $1000^{\circ} \mathrm{C}$ and pumping off the $\mathrm{CO}_{2}$. The reaction was complete in 1-4 hours, and when their product was analyzed by $x$-ray fluorescence, no $\mathrm{Pt}$ impurity was detected.

Arons et al. (4) found that slow heating of $\mathrm{Li}_{2} \mathrm{CO}_{3}$ under a vacuum $\left(10^{-3}\right.$ torr $)$ invited unwanted $\mathrm{Pt}$ contamination in high purity samples. Instead, he quickly heated the $\mathrm{Li}_{2} \mathrm{CO}_{3}$ in a $\mathrm{Pt}$ crucible by induction heating. By this technique the sample temperature reached $1200-1300^{\circ} \mathrm{C}$ in $5-10$ minutes and the process was completed within 30 minutes. The Pt crucible used was not cleaned between batches but allowed to develop a reaction layer which inhibited the transfer of Pt to the sample to less than $10 \mathrm{wppm}$. By employing this technique, Arons et al. were able to minimize the Total Metallic Impurities (TMI) to $<200 \mathrm{wppm}$ and $\mathrm{LiOH}$ to $<0.5 \mathrm{wt} \%$. The crystallite size of the $\mathrm{Li}_{2} \mathrm{O}$ was initially in the $10-30 \mu \mathrm{m}$ region but could be reduced to $<10 \mu \mathrm{m}$ by ball milling for 8-24 hours under a dry inert gas environment. High-density $\mathrm{Al}_{2} \mathrm{O}_{3}$ grinding media and a $\mathrm{jar}$ mill were used to limit impurity pick-up due to ball milling to < $100 \mathrm{wppm} \mathrm{TMI}$, predominately $\mathrm{Al}_{2} \mathrm{O}_{3}$ and $\mathrm{SiO}_{2}$.

Larsen and $\operatorname{Ortman}^{(5)}$ have recently developed a processing approach to $\mathrm{Li}_{2} \mathrm{O}$ where $\mathrm{LiOH}$ is converted to $\mathrm{Li}_{2} \mathrm{O}_{2}$ in a nitrogen atmosphere glove box slowly heated under a $10^{-3}$ torr vacuum in a pyrex tube to $297^{\circ} \mathrm{C}$, and then heated in a Pt crucible to $800^{\circ} \mathrm{C}$ for. $2-10$ days. The final product had only $0.03 \mathrm{wt} . \%$ Pt and $0-0.2$ wt.\% $\mathrm{LiOH}$ and $\mathrm{Li}_{2} \mathrm{CO}_{3}$. Larsen and Ortman contend that slow heating is the key for removing $\mathrm{Li}_{2} \mathrm{CO}_{3}$ and $\mathrm{LiOH}$, which are considered to be more reactive with $\mathrm{Pt}$ than $\mathrm{Li}_{2}$. They used their material for melting point determinations and in reactions with other oxides. 
Anno and Boeing (6) employed a patented two-stage process to produce porous $\mathrm{Li}_{2} \mathrm{O}$. slugs and microspheres. In the first stage, under an argon atmosphere, anhydrous $\mathrm{LiOH}$ was melted $\odot 500^{\circ} \mathrm{C}$ in an $\mathrm{Ag}$ crucible and then cooled to room temperature. Next, the solidified $\mathrm{LiOH}$ sample was heated to $150^{\circ}-200^{\circ} \mathrm{C}$ and then to $700^{\circ} \mathrm{C}$ under $10^{-5}$ torr to insure decomposition of $\mathrm{LiOH}$ to $\mathrm{Li}_{2} \mathrm{O}$. The result was a 98.1 wt. $\stackrel{\circ}{\circ}$ pure $L i_{2} \mathrm{U}$ slug with an average pore spacing of $\approx 5$ um. The remaining 1.9 wt.\% was determined to be $\mathrm{LiOH}$ with no mention of any metallic impurities. The above method was modified to produce porous, $100 \mu \mathrm{m}, \mathrm{Li}_{2} 0$ microspheres with an average pore spacing $\leq 10 \mu \mathrm{m}$. In this process, the molten $\mathrm{LiOH}$ was fed through a small bore vertical tube to form a liquid jet which was disrupted, with the resulting microspheres of $\mathrm{LiOH}$ being cooled under argon. The $\mathrm{LiOH}$ microspheres were then similarly converted to $\mathrm{Li}_{2} \mathrm{O}$ microspheres as with the bulk samples.

Thornton et al. (7) were partially successful in making $\mathrm{Li}_{2} \mathrm{O}$ microspheres by decomposing $\mathrm{Li}_{2} \mathrm{O}_{2}$ granules in a plasma. Due to a lack of a controlled atmosphere, the microsphere samples range in composition from 22 to $65 \mathrm{wt. \%}$ $\mathrm{Li}_{2} \mathrm{O}$ with the remainder being $\mathrm{LiOH}$. They indicated further work was needed to increase the $\mathrm{Li}_{2} \mathrm{O}$ percentage to acceptable levels. No metalitic impurities were reported for the $\mathrm{Li}_{2} 0$ samples.

Shirido et a1. (8) successfully developed a procedure for $\mathrm{Li}_{2} \mathrm{O}$ single crystal production. Since $\mathrm{Li}_{2} \mathrm{O}$ was so reactive with available crucible materials, they chose a floating zone technique whereby a feed rod and a seed rod were suspended at one of the foci of an infrared imaging furnace with $1.5 \mathrm{kw}$ halogen lamp and ellipsoidal reflector to creater the heat needed for melting. The furnace atmosphere consisted of a high purity argon gas to minimize $\mathrm{CO}_{2}$ and $\mathrm{H}_{2} \mathrm{O}$ pick-up.

\section{$2.3 \mathrm{Li}_{2} \mathrm{O}-\mathrm{Al}_{2} \mathrm{O}_{3}$ SYSTEM}

\subsection{1 $\mathrm{Li}_{5} \mathrm{AlO}_{4}$}

Guggi et al. (9) prepared $\alpha-\mathrm{Li}_{5} \mathrm{AlO}_{4}$ according to the reaction:

$5 \mathrm{Li}_{2} \mathrm{O}_{2}+\alpha-\mathrm{Al}_{2} \mathrm{O}_{3} \rightarrow 2\left(\alpha-\mathrm{Li}_{5} \mathrm{AlO}_{4}\right)+5 / 2 \mathrm{O}_{2}$ 
by heating a mixture (mole ratio, 5:1) of $\mathrm{Li}_{2} \mathrm{O}_{2}$ and $\alpha-\mathrm{Al}_{2} \mathrm{O}_{3}$ in a $\mathrm{Ag}$ boat to $500^{\circ} \mathrm{C}$ in dry air for 140 hours. The high temperature phase, $\mathrm{B}-\mathrm{Li}_{5} \mathrm{AlO}_{4}$, was produced by either heating $\alpha-\mathrm{Li}_{5} \mathrm{AlO}_{4}$ in a $\mathrm{Ag}$ boat in an argon stream at $850^{\circ} \mathrm{C}$ for 72 hours or by calcining $\alpha-\mathrm{Li}_{5} \mathrm{AlO}_{4}$ to $1000^{\circ} \mathrm{C}$ in a $\mathrm{Pt}$ crucible under a high vacuum. No particle size or purity information were reported, in either approach.

Lehmann and Hesselbarth ${ }^{(10)}$ tempered a mixture of $\mathrm{Li}_{2} \mathrm{O}$ and $\propto-\mathrm{Al}_{2} \mathrm{O}_{3}$ at $500^{\circ} \mathrm{C}$ in air to produce $\alpha-\mathrm{Li}_{5} \mathrm{ArO}_{4}$. If $\mathrm{Li}_{2} \mathrm{CO}_{3}$ was used in place of the $\mathrm{Li}_{2} \mathrm{O}$, the reaction did not proceed to completion even at $600^{\circ} \mathrm{C}$.

LạGinestra et.al. (11) used a $\gamma-\mathrm{Al}_{2} \mathrm{O}_{3}$, precipitated from $\mathrm{Al}\left(\mathrm{NO}_{3}\right)_{3}$ in an ammonia solution, as a raw material because of its higher surface area and thus $i$ ts higher reactivity in the solid state. They were able to form $\gamma-\mathrm{Li}{ }_{5} \mathrm{AlO}_{4}$ using both $\mathrm{Li}_{2} \mathrm{O}_{2}$ or $\mathrm{Li}_{2} \mathrm{O}$ with $\gamma-\mathrm{Al}_{2} \mathrm{O}_{3}$. At temperatures bel ow $500^{\circ} \mathrm{C}$ phases. such as $\mathrm{Li}_{2} \mathrm{O}$ and $\gamma-\mathrm{Al}_{2} \mathrm{O}_{3}$ were still present where as at higher temperatures $\left(600^{\circ}-700^{\circ} \mathrm{C}\right)$ the phases of $\gamma-\mathrm{LiAlO}_{2}$, LiO and $\gamma-\mathrm{Li}_{5} \mathrm{AlO}_{4}$ were observed. In addition, when $\mathrm{Li}_{2} \mathrm{CO}_{3}$ or $\mathrm{LiNO}_{3}$ was used as a starting reagent, $\gamma-\mathrm{LiAlO}{ }_{2}$ was obtained, regardless of temperature. Crucible material, particle size, and purity were not revealed by the authors.

Hoppe and Konig ${ }^{(12)}$ used $\beta-\mathrm{Li}_{5} \mathrm{AlO}_{4}$ single crystals to refine the crystalline data for this material. The single crystals were produced by reacting $\mathrm{Li}_{2} 0$, obtained from $\mathrm{LiOH}$ decomposition, and $\mathrm{Al}_{2} \mathrm{O}_{3}$ in a $\mathrm{Ni}-\mathrm{lined}$, high pressure, calorimeter at $740^{\circ} \mathrm{C}$ for 14 days under an Ar atmosphere. Stewner and Hoppe made $\alpha-\mathrm{Li}_{5} \mathrm{AlO}_{4}$ single crystals in a similar manner but only heated to $700^{\circ} \mathrm{C}$ for 2 days in a Ni-lined, high-pressure calorimeter. No purity specifications for either crystal were discussed.

\subsection{2 $\mathrm{LiAlO}_{2}$}

The preparation of lithium aluminate $\left(\mathrm{LiAlO}_{2}\right)$ in any of $i$ ts three forms $(\alpha, \beta, \gamma)$ has centered around two reactions:

$$
\begin{aligned}
& \mathrm{Li}_{2} \mathrm{CO}_{3}+\mathrm{Al}_{2} \mathrm{O}_{3} \rightarrow 2 \mathrm{LiAlO}_{2}+\mathrm{CO}_{2} . \\
& \mathrm{Li}_{2} \mathrm{O}+\mathrm{Al}_{2} \mathrm{O}_{3} \rightarrow 2 \mathrm{LiAlO}_{2}
\end{aligned}
$$


Humme ${ }^{(14)}$ prepared $\gamma-\mathrm{LiAlO}_{2}$ by ball milling $\mathrm{Li}_{2} \mathrm{CO}_{3}$ and $\mathrm{Al}_{2} \mathrm{O}_{3}$ in a distilled water slurry, drying and then calcining in $\mathrm{Al}_{2} \mathrm{O}_{3}$ crucibles $01300^{\circ} \mathrm{C}$ for 7 to 15 hours. No purity and particle size data were given.

Guggi et al. (9) prepared $\gamma-\mathrm{LiAlO}_{2}$ from a stoichiometric mixture of finely ground $\mathrm{Li}_{2} \mathrm{O}$ and $\alpha-\mathrm{Al}_{2} \mathrm{O}_{3}$ which was pressed into pellets and heated $0900^{\circ} \mathrm{C}$ for 30 hours in a Pt boat in air. The pellets were then sealed in a Mo tube by electron beam welding, heated to $2000^{\circ} \mathrm{C}$ and cooled. The fused material contained $\approx 300$ wppm Mo.

Lejus and Collongues $(15)$ mixed aluminum acetate $\left(\mathrm{Al}_{3} \mathrm{C}_{2} \mathrm{H}_{3} \mathrm{O}_{2}\right)$ with the $\mathrm{Li}_{2} \mathrm{CO}_{3}$ and produced $\alpha-\mathrm{LiAlO}_{2}$ upon heating to $580^{\circ} \mathrm{C}$. Lehmann and Hesselbarth fired an equimolar mixture of $\mathrm{Li}_{2} \mathrm{CO}_{3}$ and $\alpha-\mathrm{Al}_{2} \mathrm{O}_{3} \odot 600^{\circ} \mathrm{C}$ and got $\alpha-\mathrm{LiAlO}_{2}$. Marezio and Remeika (17) subjected $\gamma-\mathrm{LiAlO}_{2}$ to a pressure of $35 \mathrm{kbar}$ O $850^{\circ} \mathrm{C}$ and, after quenching to room temperature, found $\alpha-\mathrm{LiAlO}_{2}$. Although the sample was in a Ta container, no contamination was reported.

Chang and Margrave ${ }^{(18)}$ reported a high-pressure, high-temperature synthes is for $\mathrm{B}^{-\mathrm{LiAlO}_{2}}$. They pressed a 2:1 molar mixture of $\mathrm{Li}_{2} \mathrm{O}_{2}$ and $\mathrm{ATN}$ a $22 \mathrm{kbar}$ c $550^{\circ}$ for 11 hours. When the time was lengthened to 25 hours, $\alpha-\mathrm{LiAlO}_{2}$ was formed. Tantalum served as the die lining, with little contamination reported.

Strickler and Roy ${ }^{(19)}$ produced $\alpha-\mathrm{LiAlO}_{2}$ by dissolving $\mathrm{LiNO}$ and $\mathrm{Al}\left(\mathrm{NO}_{3}\right)_{3}$ $9 \mathrm{H}_{2} \mathrm{O}$ in deionized water, adding $\mathrm{NH}_{4} \mathrm{OH}$, and then evaporating the $\mathrm{H}_{2} \mathrm{O}$ on a stream bath. Afterwards, the material was put into a Pt crucible and decomposed $0750^{\circ} \mathrm{C}$ for several hours. This procedure resulted in a partly amorphous material which was converted to fully crystalline e $950^{\circ} \mathrm{C}$ and above. No purity or particle size was reported.

Arons et al. ${ }^{(4)}$ ball milled high purity $\alpha-\mathrm{Al}_{2} \mathrm{O}_{3}$, with a grain size of $<0.02 \mu \mathrm{m}$, and $\mathrm{Li}_{2} \mathrm{CO}_{3}$ in methanol. The slurry was then centrifuged, dried, and calcined in $\mathrm{Al}_{2} \mathrm{O}_{3}$ crucibles $0650^{\circ} \mathrm{C}$ for $72-96$ hours in air yielding a phase-pure $\alpha-\mathrm{LiAlO}_{2}$ with a particle size of $\approx 0.1 \mu \mathrm{m}$. Another technique for $\alpha-\mathrm{LiAlO}_{2}$ production involved making a slurry of aqueous lithium acetate $\left(\mathrm{LiC}_{2} \mathrm{H}_{3} \mathrm{O}_{2}\right)$ and fine grained $\alpha-\mathrm{Al}_{2} \mathrm{O}_{3}$, then spray drying before calcination. Agglomerates of the $\alpha-\mathrm{LiAlO} \mathrm{O}_{2}$ powder were cold pressed and fired in air to $1000^{\circ} \mathrm{C}-1100^{\circ} \mathrm{C}$ for 
1 hour to convert $\alpha$ to $\gamma-\mathrm{LiATO}{ }_{2}$. Firing at $1200^{\circ} \mathrm{C}$ in air resulted in $\gamma-\mathrm{L}: \mathrm{AATO}_{2}$ with a minor amount of $\mathrm{LiAl}_{5} \mathrm{O}_{8}$ due to partial Li2O volatilization. Contamination of either powders was not mentioned.

Gurwel1 ${ }^{(20)}$ analyzed one of the commercially available LiAlO $\mathrm{L}_{2}$ powders: and discovered $\approx 3$.wt.\% unreacted $\mathrm{Li}_{2} \mathrm{CO}_{3}$ and both $\alpha$ and $\gamma$-LiAlO 2 phases. Particle sizes ranged from 150 to $30 \mu \mathrm{m}$ for the material.

Single crystals of $\gamma-\mathrm{LiAlO}_{2}$ were grown from a flux as described by Marezio (21). The flux, consisting of $\mathrm{Li}_{2} \mathrm{CO}_{3}, \alpha-\mathrm{Al}_{2} \mathrm{O}_{3}, \mathrm{~B}_{2} \mathrm{O}_{3}$ and $\mathrm{PbO}$, was placed in a $\mathrm{Pt}$ crucible, heated to $1300^{\circ} \mathrm{C}$ for 5 hours, and then slowly cooled to room temperature. The $\gamma-\mathrm{LiAlO}_{2}$ single crystals were extracted from the solidified flux by using acetic acid to remove the $\mathrm{B}_{2} \mathrm{O}_{3}$ and $\mathrm{PbO}$ compounds leaving only the $\gamma-\mathrm{LiAlO}_{2}$ crystals. No purity data. was offered by the author.

\section{$2.4 \mathrm{Li}_{2} \mathrm{O}-\mathrm{SiO}_{2}$ SYSTEM}

\subsection{1. $\mathrm{Li}_{4} \mathrm{SiO}_{4}$}

Equation (8) has been used by many investigators to produce $\mathrm{Li}_{4} \mathrm{SiO}_{4}$ for their work.

$\mathrm{Li}_{2} \mathrm{CO}_{3}+\mathrm{SiO}_{2} \rightarrow \mathrm{Li}_{4} \mathrm{SiO}_{4}+\mathrm{CO}_{2}+$

Soga (22) prepared $\mathrm{Li}_{4} \mathrm{SiO}_{4}$ for thermal expansion measurements by wet milling $\mathrm{Li}_{2} \mathrm{CO}_{3}$ and $\mathrm{SiO}_{2}$ under alcohol and heating the mixture in a Pt crucible at $1100^{\circ} \mathrm{C}$ for 20 hours. No mention was made of the material's chemical purity or of any reaction with the $\mathrm{Pt}$ crucible.

Dubey and West ${ }^{(23)}$ reacted $\mathrm{Li}_{2} \mathrm{CO}_{3}$ and $\mathrm{SiO}_{2}$ in $\mathrm{Au}$ foil boats a $700^{\circ}-800^{\circ} \mathrm{C}$ for 24 hours to produce $\mathrm{Li}_{4} \mathrm{SiO}_{4}$ in order to study its high-low crystallographic transformation. Hodge et al. (24) following a similar path as Dubey, reacted the mixture in $\mathrm{Au}$ foil boats a $600^{\circ} \mathrm{C}$ to remove the bulk of the $\mathrm{CO}_{2}$ and finally fired o $800^{\circ}-900^{\circ} \mathrm{C}$ for one to two days. Wittman and Modern ${ }^{(25)}$ used a Pt crucible and heated the mixture to $1350^{\circ} \mathrm{C}$ to accomplish the reaction in several hours. Final product purities were not reported in these cases. Kracek (26) 
heated highly purified $\mathrm{Li}_{2} \mathrm{CO}_{3}$ and quartz $\left(\mathrm{SiO}_{2}\right)$ e $750^{\circ}-800^{\circ} \mathrm{C}$ to get $\mathrm{Li}_{4} \mathrm{SiO}_{4}$ in a Pt crucible, but noticed that the crucible had been severely attacked and was lined with an olive-gray deposit. Suiter ${ }^{(27)}$ noticed similar olivegray deposits on a $\mathrm{Pt}$ crucible after heating a mixture of high purity $\mathrm{Li}_{2} \mathrm{CO}_{3}$ and $\mathrm{SiO}_{2}$ at $750^{\circ} \mathrm{C}$ for 2 days in flowing He. Although both powders had less than 5 wppm Pt initially, the final product contained $\approx 1000 \mathrm{wppm}$ Pt.

Suiter et al. ${ }^{(28)}$ prepared high purity (< $500 \mathrm{wppm} \mathrm{TMI)} \mathrm{Li}_{4} \mathrm{SiO}_{4}$ by an organometallic route using $\mathrm{Li}_{2} \mathrm{CO}_{3}$ dissolved in acetic acid and tetraethylorthosilicate $\left(\mathrm{C}_{2} \mathrm{H}_{5} \mathrm{O}\right)_{4} \mathrm{Si}$, in isopropyl alcohol. The solutions were mixed, heated to dryness, and slowly calcined in $\mathrm{SiO}_{2}$ crucibles $0700^{\circ}-800^{\circ} \mathrm{C}$ to produce the desired result. Reaction times took anywhere from 4-24 hours, depending upon the sample size. Particle sizes ranged from 30 to $10 \mu \mathrm{m}$ and were easily reduced to $<5 \mu \mathrm{m}$ by dry ball milling for 8-48 hours the powder in a high density $\mathrm{Al}_{2} \mathrm{O}_{3}$ jar with $\mathrm{Al}_{2} \mathrm{O}_{3}$ grinding medium under an inert gas atmosphere. The sample impurity level only increased $\approx 100 \mathrm{wppm} A 1$ due to the ball milling operation.

Tranqui et al. (29) grew $\mathrm{Li}_{4} \mathrm{SiO}_{4}$ single crystals from a $\mathrm{LiOH} \cdot \mathrm{H}_{2} \mathrm{O}$ and $\mathrm{SiO}_{2}$ melt $01250^{\circ} \mathrm{C}$ in a $\mathrm{Pt}$ crucible by the Czochralski pulling technique. Single crystals were obtained by polynucleation of the melt on a Pt wire and then pulling to small diameters to effect single crystal growth. Total impurities were listed at 0.5 wt.\%, with no individual breakdown being reported.

\subsection{2 $\mathrm{Li}_{2} \mathrm{SiO}_{3}$}

The most common approach to $\mathrm{Li}_{2} \mathrm{SiO}_{3}$ has been:

$\mathrm{Li}_{2} \mathrm{CO}_{3}+\mathrm{SiO}_{2} \stackrel{>700^{\circ} \mathrm{C}}{\longrightarrow} \mathrm{Li}_{2} \mathrm{SiO}_{3}+\mathrm{CO}_{2} \uparrow$

Hess ${ }^{(30)}$ melted the above reactants $01240^{\circ} \mathrm{C}$ to get $\mathrm{Li}_{2} \mathrm{SiO}_{3}$, while West ${ }^{(31)}$ utilized the same raw materials but heated them to $600^{\circ}-700^{\circ} \mathrm{C}$ and then to $800^{\circ}-850^{\circ} \mathrm{C}$ for $24-48$ hours. Neither investigator reported the crucible composition, the particle size nor the purity data of the finished powders. 
Noshiro and Jitsurgiri ${ }^{(32)}$ melted silicic acid $\left(\mathrm{H}_{2} \mathrm{SiO}_{3} \cdot \mathrm{nH}_{2} \mathrm{O}\right)$ and $\mathrm{Li}_{2} \mathrm{CO}_{3}$ Q $1400^{\circ}-1500^{\circ} \mathrm{C}$ in a. P.t crucible, in air, for 3-5 hours, and an amorphous $\mathrm{Li}_{2} \mathrm{SiO}_{3}$ was obtained. However, by subsequent heat treating $\mathrm{a} 750^{\circ} \mathrm{C}$ for 24 hours, the $\mathrm{Li}_{2} \mathrm{SiO}_{3}$ was $100 \%$ crystallized. Lithium glasses require much greater $\mathrm{SiO}_{2}$ contents (> $70 \mathrm{wt} . \%$ ) in order to be stable in the temperature ranges of interest. Lithium disilicate $\left(\mathrm{Li}_{2} \mathrm{Si}_{2} \mathrm{O}_{5}\right)$ for example, is used in some glass-ceramic systems and is partially crystallized in the $400-600^{\circ} \mathrm{C}$ temperature region. Bennington et al. (33) heated a stoichiometric mixture of reagent grade $\mathrm{Li}_{2} \mathrm{CO}_{3}$ and silicic acid in a $\mathrm{Ni}$ crucible for 8 days $0.700^{\circ} \mathrm{C}$, 3 days $0800^{\circ} \mathrm{C}$ and 4 days $9900^{\circ} \mathrm{C}$; finally, the material was heated for 8 days a $1100^{\circ} \mathrm{C}$ in $\mathrm{Pt}$ before being $\mathrm{OK}$ to determine the heat capacity of $\mathrm{Li}_{2} \mathrm{SiO}_{3}$. Both groups of investigators did not discuss purity data or particle size distributions for their materials.

\section{$2.5 . \mathrm{Li}_{2} \mathrm{O}-\mathrm{TiO}_{2}$ SYSTEM.}

\subsection{1 $\mathrm{Li}_{4} \mathrm{TiO}_{4}$}

Dubey and West $(23,34)$ prepared $\mathrm{Li}_{4} \mathrm{TiO}_{4}$ by the reaction

$2 \mathrm{Li}_{2} \mathrm{CO}_{3}+\mathrm{TiO}_{2}$ (rutile) $\frac{800-900^{\circ} \mathrm{G}}{24 \mathrm{~h}} \mathrm{Li}_{4} \mathrm{TiO}_{4}+2 \cdot \mathrm{CO}_{2} \uparrow$

The reactants were heated in air and contained in an Au boat. If the reaction was carried out for only a few hours, the product contained $\mathrm{Li}_{4} \mathrm{TiO}_{4}$ with small amounts of $\mathrm{Li}_{2} \mathrm{CO}_{3}$ and $\mathrm{Li}_{2} \mathrm{TiO}_{3} \cdot \mathrm{Li}_{4} \mathrm{TiO}_{4}$ was found to react readily. with $\mathrm{CO}_{2}$ and if left exposed to air for several weeks, a $50 \%$ conversion to $\mathrm{Li}_{2} \mathrm{CO}_{3}$ and disordered $\mathrm{Li}_{2} \mathrm{TiO}_{3}$ occurred. In addition, $\mathrm{Li}_{4} \mathrm{TiO}_{4}$ readily reacted with $\mathrm{Pt}$ at temperatures above $800^{\circ} \mathrm{C}$, especially in the presence of $\mathrm{CO}_{2} \cdot$ No purity or particle size was listed for the products.

\subsection{2 $\mathrm{Li}_{2} \mathrm{TiO}_{3}$}

While equation (11) has been used extensively to produce $\mathrm{Li}_{2} \mathrm{TiO}_{3}$, process parameters have differed.

$$
\mathrm{Li}_{2} \mathrm{CO}_{3}+\mathrm{TiO}_{2} \rightarrow \mathrm{Li}_{2} \mathrm{TiO}_{3}+\mathrm{CO}_{2} \uparrow
$$


Lokotosh and Lisnyak ${ }^{(35)}$ were able to produce $\mathrm{Li}_{2} \mathrm{TiO}_{3}$ by calcining the reactants $0900^{\circ} \mathrm{C}$ in air for 4 hours while King $(36)$ needed 70 hours o $1000^{\circ}-$ $1050^{\circ} \mathrm{C}$ in a $\mathrm{Ni}$ crucible and 30 hours $\mathrm{O} 1150^{\circ} \mathrm{C}$ in a $\mathrm{Pt}$ crucible to achieve his goal. Impurities from King's procedure were 1 isted as $0.03 \mathrm{wt}$. $\% \mathrm{Si}$ and $0.06 \mathrm{wt}$. $\% \mathrm{Ni}$ and $\mathrm{Pt}$. In the work of Girard et al. (37), the reactants were fired $01250^{\circ} \mathrm{C}$ in air, ground in a porcelain ball mill for 4-5 hours in acetone, dried, pelletized and refired $01250^{\circ} \mathrm{C}$ to insure homogeneity.

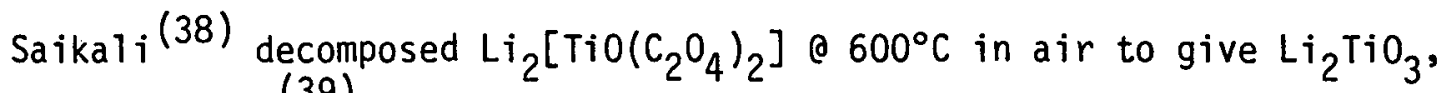
while: Morgan ${ }^{(39)}$ successfully precipitated $\mathrm{Li}_{2} \mathrm{TiO}_{3}$ from a solution of titanium tetraisopropylate in isopropanol that had been blended into a cold concentrated lithium hydroxide solution and then brought to a boil. No particle size or purity information was revealed in either study.

\section{$2.6 \quad \mathrm{Li}_{2} \mathrm{O}-\mathrm{ZrO}_{2}$ SYSTEM}

\subsection{1 $\mathrm{Li}_{8} \mathrm{ZrO}_{6}$}

Neubert and Guggi ${ }^{(40)}$ formed $\mathrm{Li}_{8} \mathrm{ZrO}_{6}$ by heating $\mathrm{Li}_{2} \mathrm{O}$ and $\mathrm{ZrO}_{2}$ in a Pt crucible according to:

$4 \mathrm{Li}_{2} \mathrm{O}+\mathrm{ZrO}_{2} \quad \stackrel{523^{\circ} \mathrm{C}}{5 \mathrm{~h}} \rightarrow \mathrm{Li}_{8} \mathrm{ZrO}_{6}$

The reaction was carried out in an argon stream to eliminate $\mathrm{CO}_{2} / \mathrm{H}_{2} \mathrm{O}$ interaction with the $\mathrm{Li}_{2} \mathrm{O}$. Scholder et al. (41) reacted $\mathrm{Li}_{2} \mathrm{O}$ and $\mathrm{ZrO}_{2}$ at $500^{\circ} \mathrm{C}$ for 12 hours and then to $550^{\circ} \mathrm{C}$ for 5 hours to get $\mathrm{Li}_{8} \mathrm{ZrO}_{6}$. Belyaev and Annopol'skij (42) heated $\mathrm{LiOH}$ and $\mathrm{ZrO}_{2}$ \& $950^{\circ} \mathrm{C}$ for 20 hours in air before they got a homogeneous product. At less times or temperatures, the reaction proceeded slowly and resulted in mixed phases, mainly $\mathrm{Li}_{2} \mathrm{ZrO}_{3}$ and $\mathrm{Li}_{8} \mathrm{ZrO}_{6}$. In addition, when $\mathrm{Li}_{2} \mathrm{CO}_{3}$ was used as a starting material, the powders always contained mixed phases. Plyushchev and Grizik ${ }^{(43)}$ used $\mathrm{Li}_{2} \mathrm{CO}_{3}$ and $\mathrm{LiOH}$ together with $\mathrm{ZrO}_{2}$ in ratios up to $6: 1$ and still found $\mathrm{Li}_{2} \mathrm{ZrO}_{3}$ in the temperature range of $800^{\circ}-1400^{\circ} \mathrm{C}$.

Larsen and Ortman ${ }^{(5)}$ ground fused $\mathrm{Li}_{2} \mathrm{O}$ and $\mathrm{ZrO}_{2}$ under an inert gas atmosphere, 
pressed a pellet, and fired it in a Pt boat in vacuum $0590^{\circ} \mathrm{C}$ for 24 hours. The pellet was then cooled, reground and reheated for another 16 hours at $590^{\circ} \mathrm{C}$ to insure $\mathrm{Li}_{8} \mathrm{ZrO}_{6}$ homogeneity. In none of the aforementioned studies were particle size and purity information discussed.

\subsection{2 $\mathrm{Li}_{4} \mathrm{ZrO}_{4}$}

Neubert and Guggi ${ }^{(40)}$ formed $\mathrm{Li}_{4} \mathrm{ZrO}_{4}$ in a Pt boat by

$2 \mathrm{Li}_{2} \mathrm{O}+\mathrm{ZrO}_{2} \frac{900^{\circ} \mathrm{C}}{4 \mathrm{~h}} \mathrm{Li}_{4} \mathrm{ZrO}_{4}$

They found that if the raw materials were reacted at lower temperatures, the product was contaminated with significant amounts of $\mathrm{Li}_{8} \mathrm{ZrO}_{6}$ as well as unreacted $\mathrm{ZrO}_{2}$ and $\mathrm{Li}_{2} \mathrm{ZrO}_{3}$. It was also important that the starting mixture be quickly heated to avoid $\mathrm{Li}_{8} \mathrm{ZrO}_{6}$ information, due to slow thermal energy transfer: A small batch size also helped in reducing this possibility. Scholder et al. ${ }^{(41)}$ went to $1000^{\circ} \mathrm{C}$ for 3 hours to insure product phase purity.

Bel.yaev and Annopol's skij ${ }^{(42)}$ produced $\mathrm{Li}_{4} \mathrm{ZrO}_{4}$ by heating $\mathrm{LiOH}$ and $\mathrm{ZrO}_{2}$ a $950^{\circ} \mathrm{C}$ for 20 hours in air. They found that the reaction of $\mathrm{Li}_{2} \mathrm{CO}_{3}$ and $\mathrm{ZrO}_{2}$ at $550^{\circ}-750^{\circ} \mathrm{C}$ for even $\mathrm{I}$ hour led to the formation of $\mathrm{Li}_{2} \mathrm{ZrO}_{3}$, irrespective of the original reagent ratio.

\subsection{3. $\mathrm{Li}_{2} \mathrm{ZrO}_{3}$}

Several investigations $(35,42,44,45)$ were able to produce $\mathrm{Li}_{2} \mathrm{ZrO}_{3}$ in a $P t$ boat in air by

$$
\mathrm{Li}_{2} \mathrm{CO}_{3}+\mathrm{ZrO}_{2} \frac{900^{\circ} \mathrm{C}}{4 \mathrm{~h}} \mathrm{Li}_{2} \mathrm{ZrO}_{3}+\mathrm{CO}_{2} \uparrow
$$

Belyaev and Annopol'skij ${ }^{(42)}$ found that the same reaction $550^{\circ} \mathrm{C}-750^{\circ} \mathrm{C}$ for 1 hour leads to the formation of $\mathrm{Li}_{2} \mathrm{ZrO}_{3}$, irrespective of the original reagent ratio. In mixtures of $\mathrm{LiOH}$ and $\mathrm{ZrO}_{2}$, on the other hand, $\mathrm{Li}_{2} \mathrm{ZrO}_{3}$ was the only product formed between $350^{\circ}$ and $580^{\circ} \mathrm{C}$. 
Dittrich and Hoppe ${ }^{(46)}$ heated $\mathrm{Li}_{2} \mathrm{O}$ and $\mathrm{ZrO}_{2}$ in an $\mathrm{O}_{2}$ atmosphere for 7 hours (a) $900^{\circ} \mathrm{C}$ and then $30 \mathrm{~min}$. C $1200^{\circ} \mathrm{C}$ to get $\mathrm{Li}_{2} \mathrm{ZrO}_{3}$. No mention was made of final product particle size or purity, by the previous authors. Suiter et al. (28) prepared $\mathrm{Li}_{2} \mathrm{ZrO}_{3}$ from $\mathrm{Li}_{2} \mathrm{CO}_{3}$ dissolved in an ethylene glycol citric acid mixture and $\mathrm{ZrOCl}_{2}-8 \mathrm{H}_{2} \mathrm{O}$ in $\mathrm{H}_{2} \mathrm{O}$. The solution was evaporated to dryness, and air calcined $0800^{\circ}-900^{\circ} \mathrm{C}$ in porcelain crucibles to produce monoclinic $\mathrm{Li}_{2} \mathrm{ZrO}_{3}$. Firings $0700^{\circ} \mathrm{C}$ or slightly lower were sufficient to remove the organics, but crystalline conversion was incomplete and required higher temperatures. The purity levels were reduced to $<500 \mathrm{wppm}$ TMI by the use of high purity (<100 wppm) starting materials. The major problem with the powder was its extreme hygroscopic nature due to high levels of residual chlorine. To remove this obstacle, zirconyl nitrate $\left(\mathrm{ZrO}\left(\mathrm{NO}_{3}\right)_{2} \cdot \mathrm{nH}_{2} \mathrm{O}\right)$ was substituted for the $\mathrm{ZrOCl}_{2} \cdot 8 \mathrm{H}_{2} \mathrm{O}$ as the $\mathrm{Zr}$ source. The powder produced had a particle size variance of 25-5 $\mathrm{m}$ and was reduced to $<5 \mu \mathrm{m}$ by ball milling for 24-48 hours. An $\mathrm{Al}_{2} \mathrm{O}_{3}$ jar and grinding media were used with only $\approx 100$ wppm pick-up of $\mathrm{Al}_{2} \mathrm{O}_{3}$ by the powder during the milling.

\subsection{REFERENCES}

(1) Pierron, P., Buil1. Soc. Chim., 6, 235-238 (1939).

(2) Van Arkel, A. E., Flood, E. A., and Bright, N. F. H., Can. J. Chem., 31, 1009-1019 (1953).

(3) Brewer, L. and Margrave, J. J. Phys. Chem., 59, 421-425 (1955).

(4) Arons, R. M., Poeppel, R. B., Tetenbaum, M., and Johnson, C. E., J. Nucl. Mater. 103-104, 573-578 (1981).

(5) Larsen, E. M., and Ortman, M. S., University of Wisconsin, UWFDM-449, $1429(1982)$.

(6) Anno, J. N., and Boeing, H. H., Research Dynamics, Inc., U.S. Patent $\# 4,221,775(1980)$.

(7) Thornton, T. A., Schluderberg, D. C., Sze, D. K., and Zenz, F. A., J. Nucl. Mater., 85-86, 323-327 (1979).

(8) Shindo, I., Kimura, S., Noda, K., Kurasawa, T., and Nasu, S, , J. Nucl. Mater., 79, 418-419 (1979).

(9) Guggi, D., Ihle, H. R., and Neubert, A., Proc. 9th Symposium on Fusion Technology, Garmisch-Partenkirchen (FRG), Pergamon Press, pp 635-644 (1976). 
(10) Lehmann, H. A., and Hessel barth, H., Z. Anorg. Al1g. Chem., 315, $14-18(1962)$.

(11) LaGinestra, A., LoJacono, M., and Porta, P. J., Therm. Anal., 4, 5-17 (1972).

(12). Hoppe, R. and König, H., Z. Anorg. A11g. Chem., 430, 211-217 (1.977).

(13) Stewner, F., and Hoppe, R., Z. Anorg. Al1g. Chem., 380, 241-243 (1971).

(14) Hummel, F. A., J. Am. Cer. Soc., 34 (8), 235-239 (1951).

(15) Lejus, A. M. and Collongues, R.., Compt. Rend., 254, 2005-2007 (1962).

(16) Lehmann, H. A. and Hesselbarth, H., Z., Anorg. Allg. Chem., 313, $117-121$ (1961).

(17) Marezio, M. and Remeika, J. P., J. Chem. Phys., 44, 3143-3144 (1966).

(18) Chang, C. H and Margrave, J. L., J. Am. Chem. Soc., 90, 2020-2022 (1968).

(19) Strickler, D. W. and Roy, R., J. Am. Cer. Soc., 44(5), 225-230 (1961).

(20) Gurwel1, W. E., Battelle Pacific Northwest Laboratory, BNWL-CC-464, $1-21$ (1966).

(21) Marezio, M., Acta Cryst., 19, 396-400 (1965).

(22) Soga, N., J. Am. Cer. Soc., 47 (9), 468-469 (1964).

(23) Dubey, B. L. and West, A. R., J. Inorg. Nucl. Chem., 35, 3713-3717 (1973).

(24) Hodge, I. M., Ingram, M. D., and West, A. R., J. Am. Cer. Soc., 59 $(7,8), 360-365$. (1976).

(25) Wittmann, A. and Modern, E., Monatsh. Chem., 96 (2), 581-582 (1965).

(26) Kracek, F. C., J. Phys. Chem., 34 (12), 2641-2650 (1930).

(27) Suiter, D. J., McDonnell Douglas Corporation, private communication, May (1981).

(28) Suiter, D. J., Davis, J. W., and Kirkpatrick, B. A., J. Nucl. Mater., 103-104, 579-583 (1983).

(29) Tranqui, D., Shannon, R. D., and Chen, H. Y., Acta. Cryst., 35B, 24792487 (1979).

(30) Hesse, H. F., Acta Cryst., 33B, 901-902 (1977).

(31) West, A. R., J. Am. Cer. Soc., $59(3,4), 118-121$ (1976). 
(32) Noshiro, M. and Jitsurgiri Y., Asahi Garasu Kenley Hokoku, 18(2), 59-70 (1968).

(33) Bennington, K. O., Ferrante, M. J., and Stuve, J. M., U.S. Bureau of Mines, RI-8187, 1-19 (1976).

(34) Dubey, B. L. and West, A. R., Nature Phys. Sci., 235, 155-156 (1972).

(35) Lokotosh, T. A. and Lisnyak, S. S., Izv. Vyssh. Ucebn. Zeveal. Khim. Khim. Teknol., 20(9), 1278-1280 (1977).

(36) King, E. G., J. Am. Chem. Soc., 77, 2150-2152 (1955).

(37) Girard, R. T., Sims, C. T., and Wisely, H. R., General Electric Company, U.S. Patent \#3,397,080 (C1. 117-129) (1968).

(38) Saikali, Y. C. R., Hebd. Seames Acad. Sci. Sec. C., 285(16), 563-566 (1977).

(39) Morgan, P.E.D., J. Am. Cer. Soc., 57 (11), 499-500 (1974).

(40) Neibert, A., and Guggi, D., J. Chem. Thermo., 10, 297-306 (1978).

(41) Scholder, R., Rade, D., and Schwarz, H., Z. Anorg: Allg. Chem., 362, 149-168 (1968).

(42) Belyaev, E. K. and Annopol'skii, V. F., Russ: J. Inorg. Chem., 19(2), 297-299 (1974).

(43) Plyushchev, V. E.: and Grizik, A. A., Russ. J. Inorg. Chem.; $\underline{7}(9)$, 1079-1084 (1962).

(44) L'vova, A. S. and Feodos'ev, N. N., Russ. J. Inorg. Chem., g(9), $1216-1217$.

(45) Kutolin, S. A. and Druz, N. A., Inorg. Mater., I, 1451-1453 (1.965).

(46) Dittrich, V. G., and Hoppe, R. Z., Anorg. Allg. Chem., 371, 306-331 (1969). 


\subsection{CRYSTALLINE PROPERTIES}

\subsection{INTRODUCTION}

A material's phase stability with temperature and/or stoichiometry is an important consideration in the selection of solid breeder compounds. Temperature induced phase changes are of concern if they are accompanied by significant volume changes, which could lead to severe cracking in a sintered body. Due to lithium burn-up, a shift in stoichiometry is expected during the lifetime of the blanket. Any subsequent effect of this deviation would have to be taken into account in the blanket's operating limits or design. One example would be the formation of a liquid phase in the breeder which could lead to enhanced grain growth due to sintering. The increase in grain growth could in turn affect bulk tritium diffusion thus increasing tritium inventories.

\subsection{Li-0 SYSTEM}

Two stable compounds, $\mathrm{Li}_{2} \mathrm{O}(1)$ and $\mathrm{Li}_{2} \mathrm{O}_{2}(1)$, and two metastable compounds $\mathrm{LiO}_{2}(2)$ and $\mathrm{Li}_{3} \mathrm{O}_{2}(3)$ have been reported in the $\mathrm{Li}-0$ system. $\mathrm{LiO} 2$ was prepared only under controlled conditions and not considered a stable compound at room temperature. Li302 was the result of the decomposition of anhydrous $\mathrm{LiOH}$ under $10^{-5}$ torr a $360^{\circ} \mathrm{C}$ for 48 hours. Stecura (3) was also able to produce the substance at temperatures up to $730^{\circ} \mathrm{C}$ before $\mathrm{Li}_{2} \mathrm{O}$ became the final product. $\mathrm{Li}_{2} \mathrm{O}_{2}$ was studied extensively by Foppl(4) and Rode et al. (5) who found that $\mathrm{Li}_{2} \mathrm{O}_{2}$ can exist in two crystalline modifications: (1) $\alpha-\mathrm{Li}_{2} \mathrm{O}_{2}$, which is stable up to $225^{\circ} \mathrm{C}$, and (2) $\mathrm{B}-\mathrm{L} i 2 \mathrm{O}_{2}$ which decomposes at $315^{\circ}-350^{\circ} \mathrm{C}$. The remaining compound of this system, $L_{i 2} 0$, possesses a relatively high melting point $\left(>1400^{\circ} \mathrm{C}\right)$ and a high lithium atom density, thus making a most attractive solid breeding oxide material. Although a $L i-0$ phase diagram has not been completed, phase diagrams do exist for $\mathrm{Li}_{2} \mathrm{O}^{\prime} \mathrm{s}$ major phase contaminants, $\mathrm{Li}_{2} \mathrm{CO}_{3}$ and $\mathrm{LiOH}$.

The $\mathrm{Li}_{2} \mathrm{CO}_{3}-\mathrm{Li}_{2} \mathrm{O}$ has been investigated by two investigators $(6,7)$ with differing results. Papin et a1.(6) constructed the phase diagram, Figure 3.2.1, 


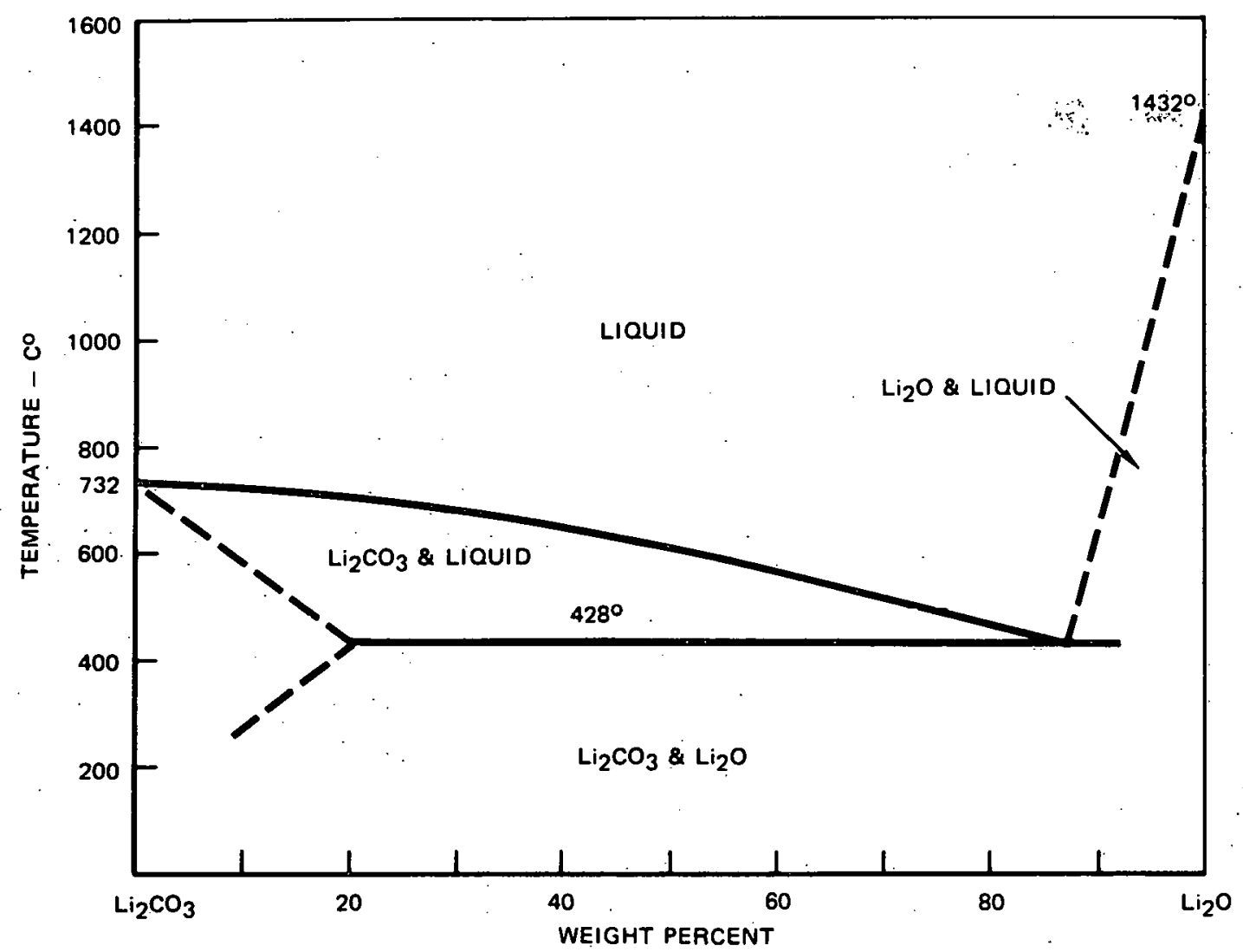

13-6098

FIGURE 3.2.1 PARTIAL PHASE DIAGRAM OF THE SYSTEM $\mathrm{Li}_{2} \mathrm{CO}_{3}-\mathrm{Li}_{2} \mathrm{O}$ ACCORDING TO PAPIN et al. (6)

revealing a eutectic $087 \mathrm{wt} \% \mathrm{Li}{ }_{2} \mathrm{O}$ at $428^{\circ} \mathrm{C}$. Compositions with less than 20. wt\% $\mathrm{Li}_{2} \mathrm{O}$ were not examined in this study. Smirnov et.al. (7) also reported a eutectic but at $705^{\circ} \mathrm{C}$ for $4 \mathrm{wt} \% \mathrm{Li}_{2} \mathrm{O}$ in their phase diagram, Figure 3.2.2. In bọth diagrams, no intermediate compounds in the $\mathrm{Li}_{2} \mathrm{CO}_{3}-\mathrm{Li}_{2} \mathrm{O}$ system are reported but the point of liquid phase formation and its extent remains in some doubt. A projected phase diagram of the system $\mathrm{LiOH}-\mathrm{Li}_{2} \mathrm{O}$, Figure 3.2.3, was presented at a Department of Energy sponsored workshop on Solid-Tritium Breeders ${ }^{(8)}$ by General Atomic. The diagram is an estimation by Dr. J. Norman based on his work with activity coefficients for $\mathrm{LiOH}$ in $\mathrm{Li}_{2} \mathrm{O}$. A eutectic appears at $\approx 480^{\circ} \mathrm{C}$ for a composition of $82 \mathrm{wt} \% \mathrm{LiOH} / \mathrm{li} \mathrm{wt} \% \mathrm{Li} \mathrm{i}_{2} \mathrm{O}$, and there are intermediate compounds formed.

Despite problems of reactions between Li, 0 and various crucible materials, no phase transitions have been reported from room temperature to its melting point. Powder $x$-ray diffraction studies performed by Swanson and co-workers revealed a pattern indexed as face centered cubic (fcc) of the antifluorite 


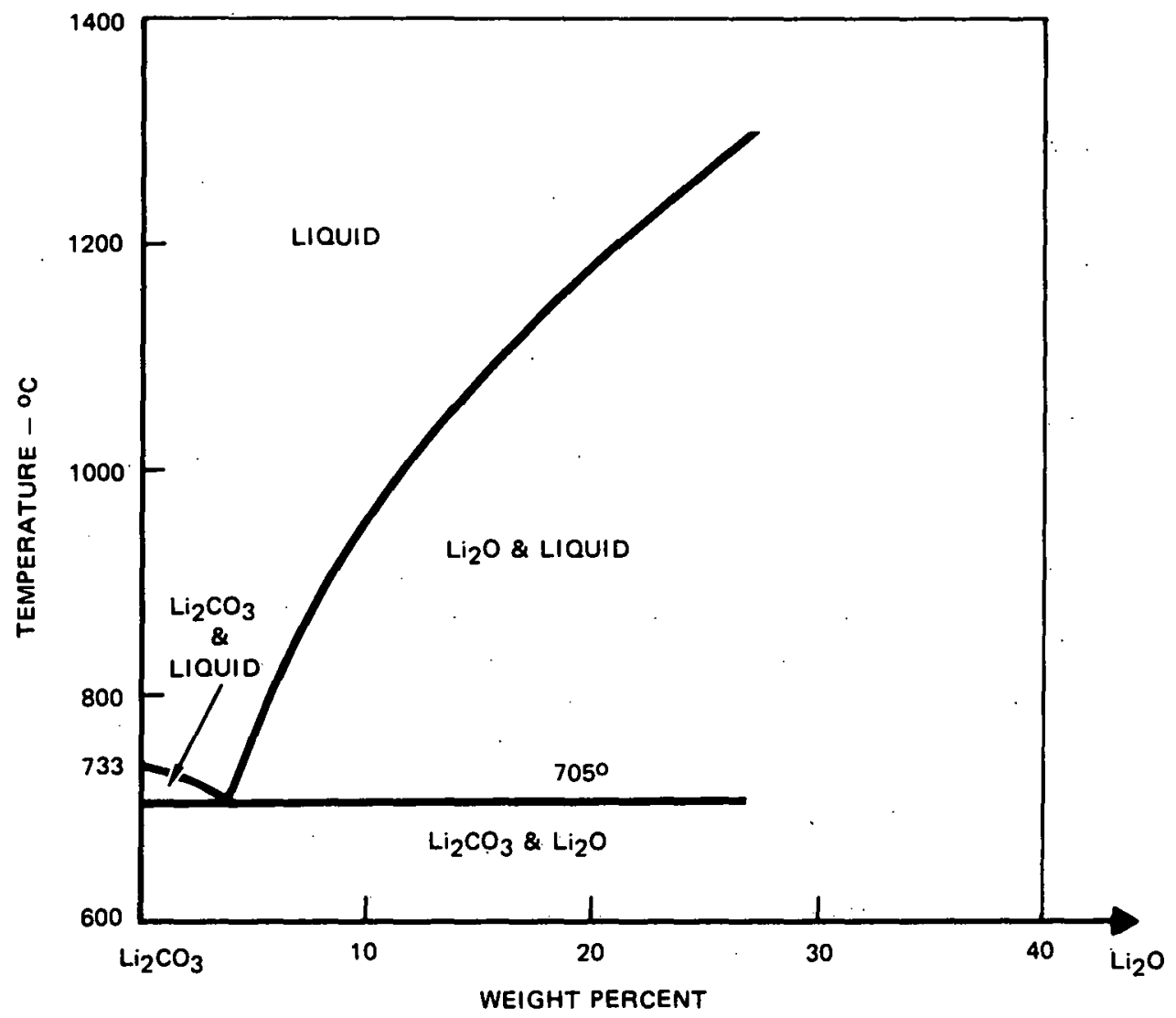

13-6099

figure 3.2.2 PARTIAL PHASE DIAGRAM OF THE SYSTEM $\mathrm{Li}_{2} \mathrm{CO}_{3}-\mathrm{Li}_{2} \mathrm{O}$ ACCORDING TO SMIRNOV et al. (7)

type. In this arrangement, the 0 atoms are located at the corners and face centers of the cubic unit cell with the lithium atoms occupying the eight tetrahedral sites. Masaki, et.al. (10) have recently proposed a rhombohedral structure in coexistance with the cubic structure and possessing a slightly different lattice parameter. The most widely recognized lattice parameter for $L_{2}{ }_{2}$ is $a=4.6114 \AA$ for the fCc structure, with the rhombohedral structure having an $a=4.610 \AA$ and $\alpha=90.16^{\circ}$. Some crystalline data for $L_{2}{ }_{2} O$ has been listed in Figure 3.2.4. 


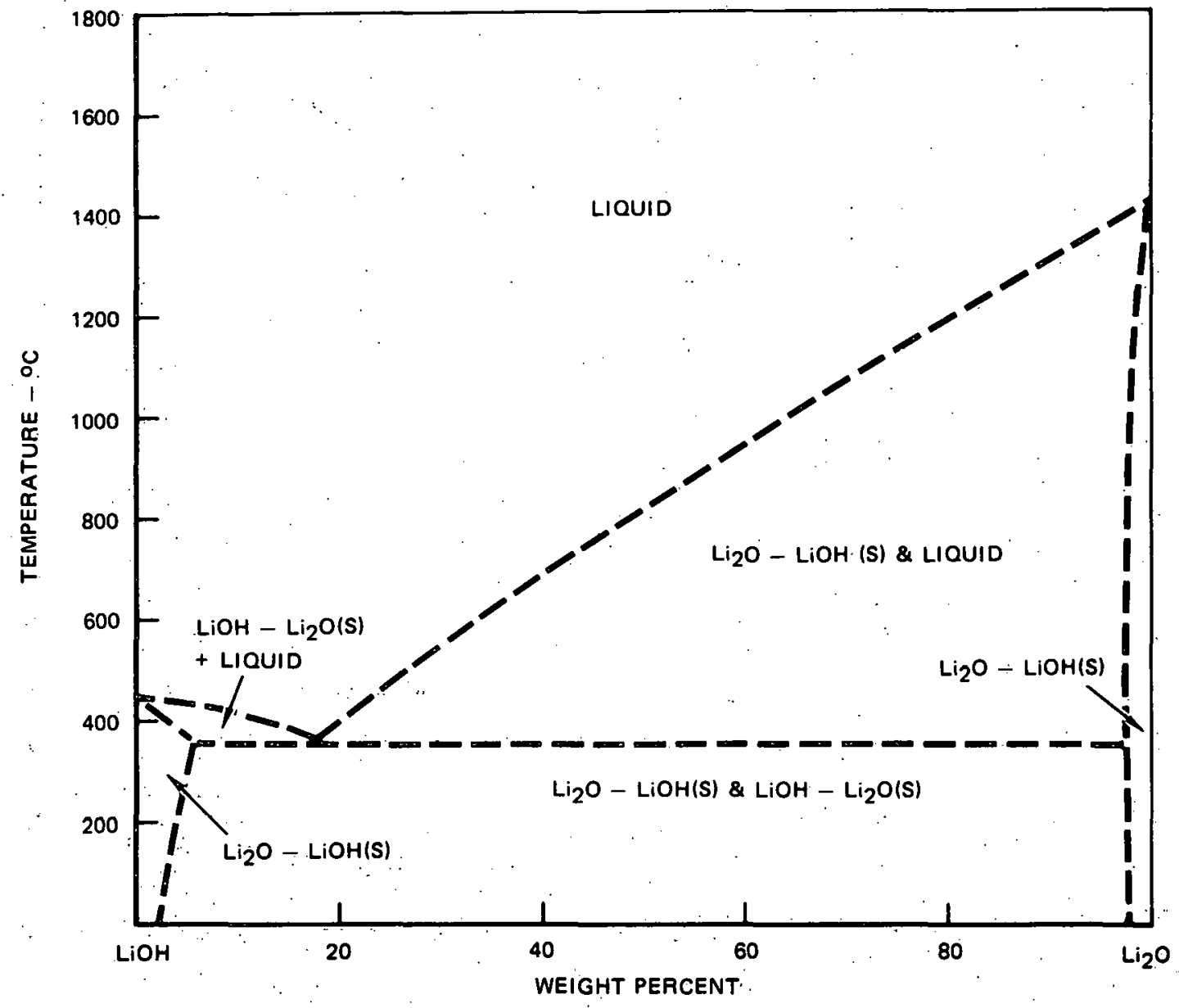

FIGURE 3.2.3 PROJECTED PHASE DIAGRAM OF THE SYSTEM LIOH-Li2O 
Figure 3.2 .4

Name:

Lithium Oxide

Formula:

$\mathrm{Li}_{2} \mathrm{O}$

Molecular Weight:

29.88

Density $\left(\mathrm{g} / \mathrm{cm}^{3}\right.$ (0 $\left.298 \mathrm{~K}\right)$ :

2.01

Lithium Atom Density $\left(\mathrm{g} / \mathrm{cm}^{3}\right)$.

0.94

Crystalline Phase(s):

Single phase

(Ref. 11)

Crystalline Structure.(s):

Face-centered cubic Rhombohedral

(Ref. 9)

(Ref. 10)

irystalline Parameters $(\AA)$ :
$a=4.6114$
(Ref. 11)
$a=4.619$
(Ref. 12)
$a=4.610$
(Ref. 10)
$\alpha=90.16^{\circ}$

Atomic Distance $(\stackrel{0}{A})$ :

$\begin{array}{ll}\text { Li-0 } & 2.00 \\ \text { Li-Li } & 2.32 \\ 0-0 & 3.27\end{array}$

Space Group:

Fm3m.

(Ref. 11)

Atoms per unit cell:

Li 8

0

4

X-Ray Diffraction

$\mathrm{Li}_{2} \mathrm{O}$

JCPDS \# 12-254 -(Cubic)

(Ref. 9)

$\mathrm{d} \AA$

$\mathrm{I} / \mathrm{I}_{\mathrm{O}}$

2.664

100

(Ref. 13)

2.306

1.6307

8

40

1.3906

1.1531

1.058

0.9413

0.8875

0.8151

0.7794

hk 1 


\section{$3.3 \stackrel{\mathrm{Li}}{2} \mathrm{O}^{-\mathrm{Al}_{2} \mathrm{O}_{2}}$ SYSTEM}

Four intermediate compounds have been reported in the $\mathrm{Li}_{2} \mathrm{O}-\mathrm{Al}_{2} \mathrm{O}_{3}$ system: $\mathrm{Li}_{5} \mathrm{AlO}_{4}, \mathrm{Li}_{3} \mathrm{AlO}_{3}, \mathrm{LiAlO}_{2}$ and $\mathrm{LiAl}{ }_{5} \mathrm{O}_{8} \cdot \mathrm{Li}_{3} \mathrm{AlO}_{3}$ was observed by LaGinesta et.al. (14) to be unstable above $400^{\circ} \mathrm{C}$ and was not actively pursued. Similarly, $\mathrm{LiAl}_{5} \mathrm{O}_{8}$ while possessing an attractively high melting point $\left(>1900^{\circ} \mathrm{C}\right)$ has such a low lithium atom density $\left(0.09 \mathrm{~g} / \mathrm{cm}^{3}\right)$ that it too will not be considered here, leaving $\mathrm{Li}_{5} \mathrm{AlO}_{4}$ and $\mathrm{LiAlO}_{2}$ as viable candidates.

A phase diagram of the $\mathrm{LiAlO}_{2}-\mathrm{Al}_{2} \mathrm{O}_{3}$ system, taken from the work of Lejus and Collonques, is shown in Figure 3.3.1. A complete phase diagram of the $\mathrm{Li}_{2} \mathrm{O}^{-}$ $\mathrm{Al}_{2} \mathrm{O}_{3}$ system has not been accomplished. Although the phase diagram only depicts two phases for $\mathrm{LiAlO}_{2}$, three have been reported: $\alpha, \beta$, and $\gamma$. Chang and Margrave ${ }^{(16)}$ synthesized $B-L i A 10_{2}$ at $370^{\circ} \mathrm{C}$ and a pressure 18 kbars, $\therefore$ as idid Dorhofer $(17)$ in order to reindex the $\beta-\mathrm{LiAlO}{ }_{2}$ powder diffraction pattern. : Although stable at room temperature, subsequent heating to $710^{\circ} \mathrm{C}$ in air led : to an irreversible transformation to $\gamma-\mathrm{LiAlO}_{2}$. The -phase was at first thought to be stable only up to $600^{\circ} \mathrm{C}$ by Lehmann and Hesselbarth (18) because * of their ability to produce $\alpha-L i A 10_{2}$ from a solid state reaction of $\mathrm{Li}_{2} \mathrm{CO}_{3}$ and $\alpha-\mathrm{Al}_{2} \mathrm{O}_{3} \mathrm{O} \cdot 600^{\circ} \mathrm{C}$ and not above. However, Lejus and $\mathrm{Collonques}(15)$ used

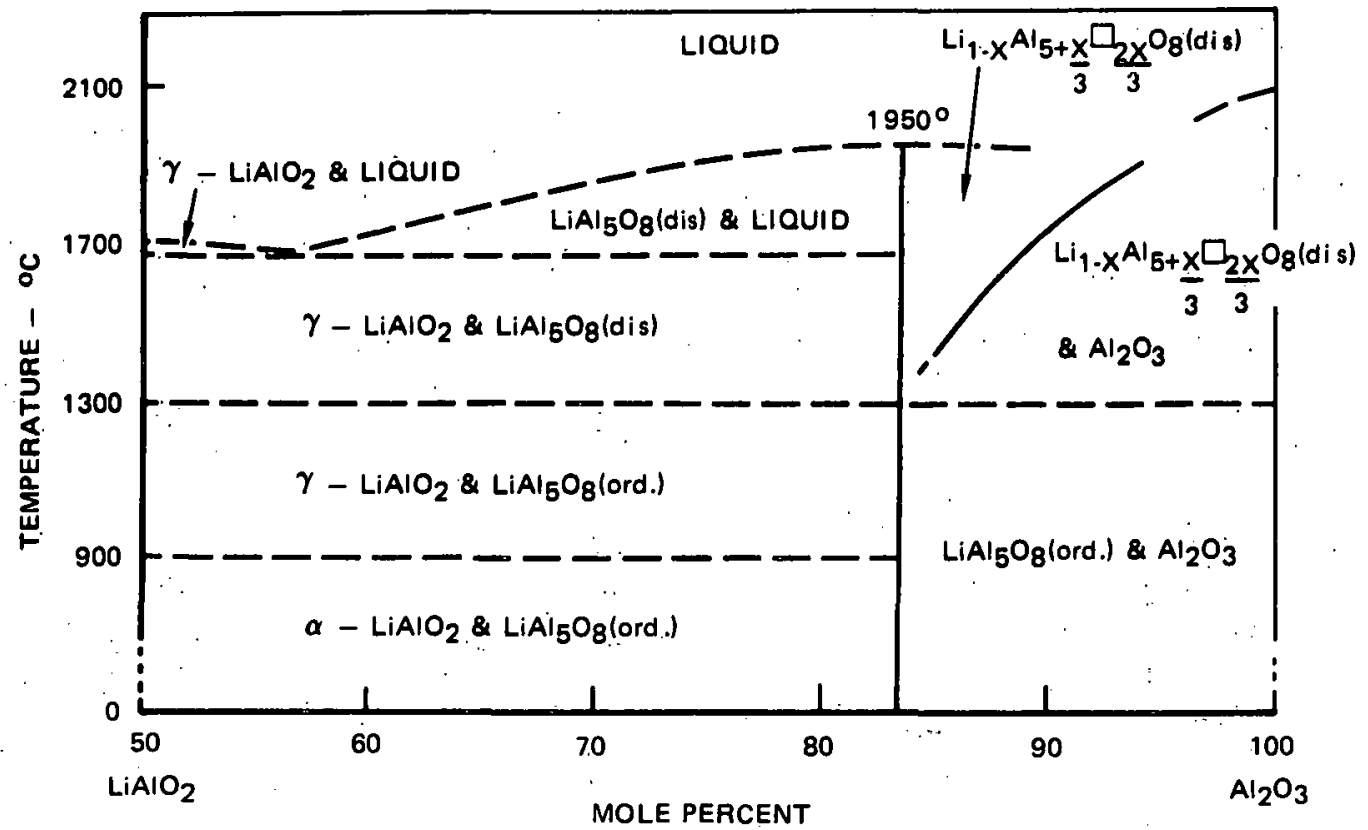

$13-6102$

FIGURE 3.3.1 PARTIAL PHASE DIAGRAM OF THE SYSTEM Li $2 \mathrm{O}-\mathrm{Al}_{2} \mathrm{O}_{3}$ 
dilatometer measurements to pinpoint the $\alpha-\gamma$ transition temperature of $900^{\circ} \mathrm{C}$, on their phase diagram. In actuality, the $\alpha-\gamma$ transformation is a sluggish, irreversible structural rearrangement that can occur anywhere between $600^{\circ}$ and $900^{\circ} \mathrm{C}$, depending upon the rate of heating, time at temperature, and character at the starting powder. As previously stated, the $\alpha-\gamma$ transition was found to be irreversible, however, Marezio and Remeika(19) subjected a sample of $\gamma-\mathrm{LiAlO}_{2}$ to a pressure of $35 \mathrm{kbar} @ 850^{\circ} \mathrm{C}$ and then quenched to room temperature and found $\alpha-\mathrm{LiAlO}_{2}$ had formed. Hummer, et.al. ${ }^{(20)}$ reported a rapid reversible inversion for $\gamma-L_{i A 10}$ between $1200^{\circ}-1300^{\circ} \mathrm{C}$.

Any loss of $\mathrm{Li}_{2} \mathrm{O}$ from $\mathrm{LiAlO}_{2}$ results in a shift in stoichiometry toward the $\mathrm{LiAl}_{5} \mathrm{O}_{8}$ composition. A eutectic is indicated at $1650^{\circ} \mathrm{C}$ for a composition of 43 mole $\% \mathrm{Li}_{2} \mathrm{O}$ and 57 mole $\% \mathrm{Al}_{2} \mathrm{O}_{3}$. At temperatures below $\approx 1650^{\circ} \mathrm{C}$, there exists a solid solution of $\mathrm{LiAlO}_{2}$ and $\mathrm{LiAl}_{5} \mathrm{O}_{8}$ phases. The compound $\mathrm{LiAl}_{5} \mathrm{O}_{8}$ is a dimorphous spinal-like structure with an ordered and disordered form depending on the temperature. A conversion temperature of $1290^{\circ} \mathrm{C}$ has been established by Lejus and Collonques ${ }^{(15)}$ for conversion for the low temperature ordered form to the high temperature disordered form. Liquid phases become apparent if the temperature exceeds $\approx 1650^{\circ} \mathrm{C}$ for compositions of $\gamma-\mathrm{LiAlO}_{2}$ and disordered $\mathrm{LiAl}_{5} \mathrm{O}_{8}$. Relationships for the $\mathrm{Li}_{2} \mathrm{O}$ rich side of $\mathrm{LiAlO}_{2}$ have not been established.

The crystallographic data for $\mathrm{LiAlO}_{2}$ is presented in Figure 3.3.2. The $\alpha$-phase possesses a higher density than the $\gamma$-phase and, consequentiy, a higher lithium atom fraction and would be more desirable from a neutron capture standpoint except for the irreversible phase transformation. The crystal structure of $-\mathrm{LiAlO}_{2}$ can be described as a distorted super-lattice of an $\mathrm{NaCl}$ arrangement where both cations ( $\mathrm{Li} \& \mathrm{Al}$ ) are in octahedral coordination. In $\gamma-\mathrm{LiAlO}_{2}$, the cations are in tetrahedral coordination and can be considered an infinite three-dimensional array of distorted tetrahedra, with aluminum and lithium atoms at the center and oxygen atoms at the vertices. Each tetrahedron shares one of $i$ ts edges with another tetrahedron of a different kind, and each vertex of every tetrahedron is shared with two additional tetrahedron, one of each kind. 
Figure 3.3 .2

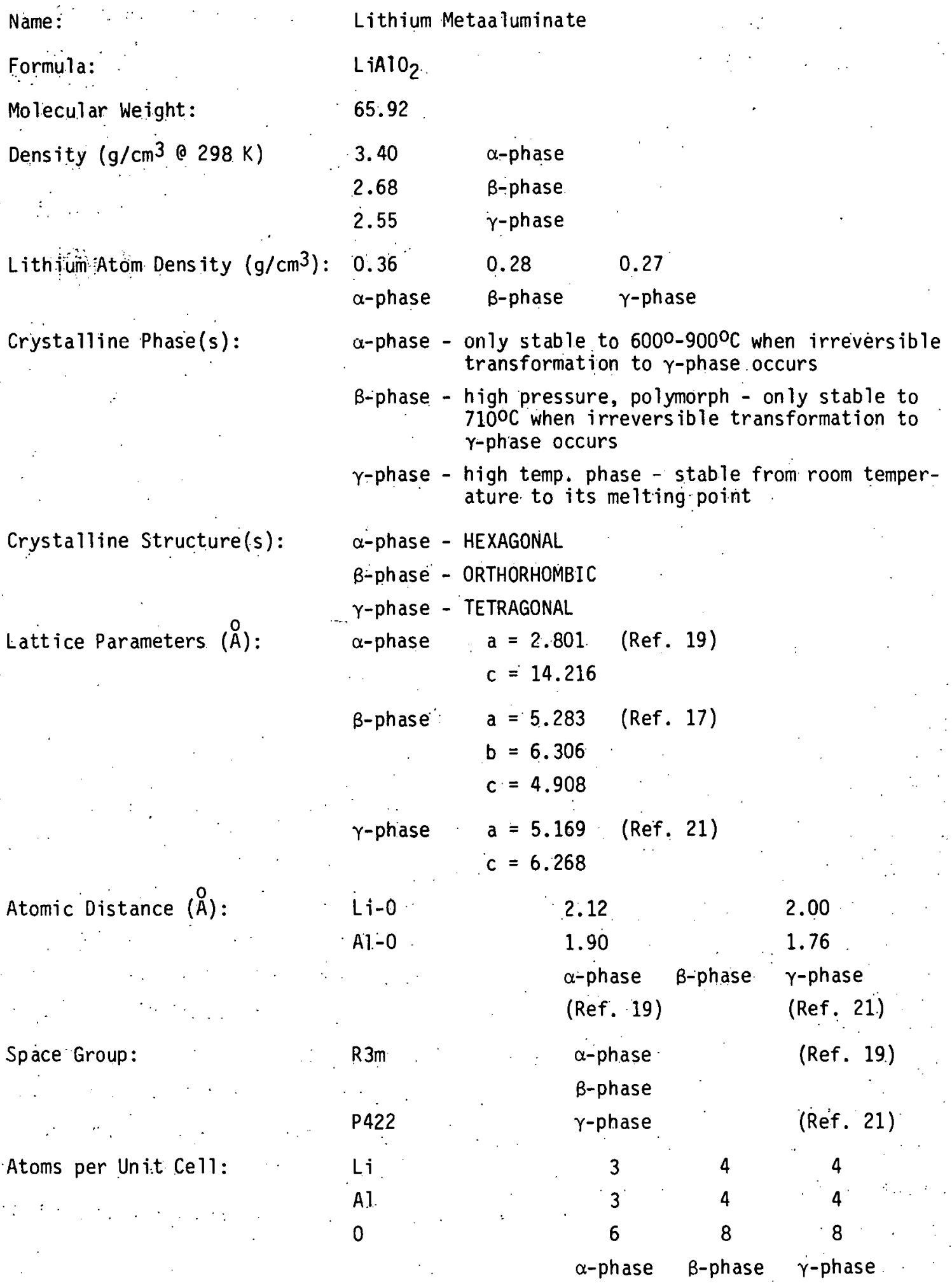


Figure 3.3.2 (Continued)

X-Ray Diffraction:

\begin{tabular}{|c|c|c|}
\hline & $\alpha-\operatorname{LiA} 10_{2}$ & \\
\hline JCPDS & Card \#19-713 - (HEXAGONAL) & (Ref. 19) \\
\hline $\mathrm{d} A$ & $I / I_{0}$ & hk ] \\
\hline 4.72 & 70 & 003 \\
\hline $\begin{array}{l}2.386 \\
2.000\end{array}$ & $\begin{array}{r}40 \\
100\end{array}$ & $\begin{array}{l}101 \\
104\end{array}$ \\
\hline 1.844 & 5 & $\begin{array}{l}104 \\
015\end{array}$ \\
\hline 1.556 & 40 & 107 \\
\hline 1.432 & 60 & 018 \\
\hline 1.399 & 60 & 110 \\
\hline 1.34 & 40 & 113 \\
\hline 1.22 & 5 & 1010 \\
\hline 208 & 10 & 021 \\
\hline 184 & 40 & 0012 \\
\hline 14 & 60 & .024 \\
\hline
\end{tabular}

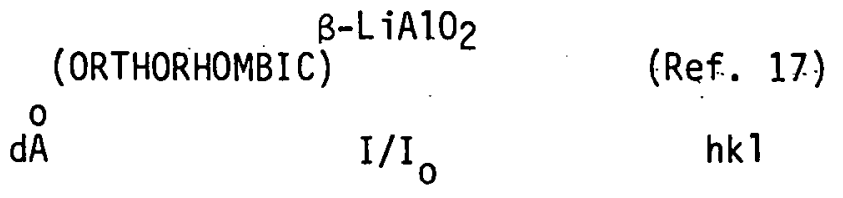

$4: 05 \quad 100 \quad 110$

$\begin{array}{lll}3.87 & 100 & 010\end{array}$

$3: 12 \quad 30 \quad 111$

$\begin{array}{lll}2.706 & 100 & 120\end{array}$

$2.639 \quad 60 \quad 200$

$\begin{array}{lll}2.452 & 100 & 022\end{array}$

$\begin{array}{lll}2.368 & 30 & 121\end{array}$

$\begin{array}{lll}2.178 & 10 & 211\end{array}$

$\begin{array}{lll}2.096 & 20 & 112\end{array}$

$\begin{array}{lll}1.818 & 30 & 122\end{array}$

$1.798 \quad 20 \quad 202$

$\begin{array}{lll}1.604 & 20 & 311\end{array}$

$\begin{array}{lll}1.576 & 30 & 040\end{array}$

$\begin{array}{lll}1.539 & 60 & 320\end{array}$

$\begin{array}{lll}1.402 & 30 & 123\end{array}$

$\begin{array}{lll}1.391 & 20 & 203\end{array}$

$\begin{array}{lll}1.303 & 30 & 322\end{array}$ 
Figure 3.3.2 (Continued)

$\gamma-\mathrm{LiATO} 2$

JCPDS Card \#18-714-(TETRAGONAL) (Ref. 21)

$\mathrm{dA}$

$\mathrm{I} / \mathrm{I}_{0} \quad \mathrm{hkT}$

$\begin{array}{lll}3.98 & 100 & 101\end{array}$

$\begin{array}{lll}3.65 & 40 & 110\end{array}$

$\begin{array}{lll}3.15 & 50 & 111\end{array}$

$2.677 \quad 990 \quad 102$

$2.584-90 \quad 200$

$2.388 \cdot 501$

$2.168=30 \quad 211$

$\begin{array}{lll}1.937 & 5 & 103\end{array}$

$\begin{array}{lll}1.860 & 50 & 52\end{array}$

$\begin{array}{lll}1.827 & 30 & 220\end{array}$

$\begin{array}{lll}1.814 & 30 & 113\end{array}$

$\begin{array}{lll}1.658 & 5 & 301\end{array}$

$\begin{array}{lll}1.633 & 30 & 310\end{array}$

$\begin{array}{lll}1.624 & 5 & 203\end{array}$

$\begin{array}{lll}1.580 & 30 & 311\end{array}$

$\begin{array}{lll}1.565 & 40 & 004\end{array}$

$\begin{array}{lll}1.508 & 80 & 302\end{array}$

$\begin{array}{rrr}1.440 & 5 & 114\end{array}$

$\begin{array}{llll}1.396 & \because 10 & 321\end{array}$

$\begin{array}{lll}1.376 & 5 & 223\end{array}$

$\begin{array}{lll}1.339 & 50 & 204\end{array}$

$1.303 \quad 70 \quad 322$

$\begin{array}{lll}1.297 & 5 & 214\end{array}$

$1.286 \quad 50 \quad 513$

$\begin{array}{lll}1.265 & 5 & 4\end{array}$

$\begin{array}{lll}1.253 & 5 & 410\end{array}$

$\begin{array}{lll}1.229 & 30 & 411\end{array}$

$\begin{array}{lll}1.218 & 70 & 330,105\end{array}$

$\begin{array}{lll}1.195 & 5 & 331.402\end{array}$

$1.189 \quad 30 \quad 224$

$\begin{array}{ll}1.182 & 10 \\ 1.156 & 323\end{array}$

$\begin{array}{lll}1.156 & 10 & 420\end{array}$

Although $\gamma-\mathrm{LiAlO}_{2}$ is a less dense phase and thus has a lower lithium atom density, it is normally considered a more practical solid breeding material because of its phase stability and ease of manufacture and fabricability.

The compound, $\mathrm{Li}_{5} \mathrm{AlO}_{4}$, while not depicted in Figure 3.3.1, has been studied by Guggi et al: (22) as a solid breeder candidate. The major attractive feature is its lithium atom density of $\approx 0.62 \mathrm{~g} / \mathrm{cm}^{3}$, which is higher than that of most 
solid breeders except for $\mathrm{Li}_{2} \mathrm{O}$ and $\mathrm{Li}_{8} \mathrm{ZrO}_{6}$. On the other hand, its major drawbacks are the low melting point $\left(1047^{\circ} \mathrm{C}\right)$ which reduces the possible operating limits and a phase transformation near $800^{\circ} \mathrm{C} . \alpha-\mathrm{Li} \mathrm{AlO}_{4}$ is the low temperature phase and is stable to $\approx 800^{\circ}$ where it undergoes an irreversible phase transformation to $\mathrm{B}-\mathrm{Li}_{5} \mathrm{AlO}_{4}$. The $\mathrm{B}$-phase was found to be stable from room temperature to its decomposition triple point of $1047^{\circ} \mathrm{C}$.

The crystallographic data for both $\alpha$ - and $\mathrm{B}-\mathrm{Li}_{5} \mathrm{Al} \mathrm{O}_{4}$ is contained in Figure 3.3.3 $\alpha-\mathrm{Li}_{5} \mathrm{AlO}_{4}$ is isostructural with $\alpha-\mathrm{Li}_{5} \mathrm{GaO}_{4}$ and is a superstructure of $\mathrm{Li} \mathrm{i}_{2} \mathrm{O}$ with scattered $\mathrm{AlO}_{4}$ groups and vacancies in the cation lattice. The $\mathrm{Al}^{3+}$ cations are octahedral coordination while the $\mathrm{Li}^{+}$cations reside in teteahedral coordination. The $\mathrm{B}-\mathrm{L} \mathrm{i}_{5} \mathrm{AlO}_{4}$ crystal structure is somewhat different in that both cations are in tetrahedral coordination with each tetrahedral being shared at two corners with another tetrahedra containing an opposite cation. 
Figure 3.3 .3

Name:

Formula:

Molecular Weight:

Density $\left(\mathrm{g} / \mathrm{cm}^{3}\right.$ (O $\left.298 \mathrm{~K}\right)$ :

Lithium Atom Density $\left(\mathrm{g} / \mathrm{cm}^{3}\right)$ :

Crystalline Phase(s):

Crystalline Structure(s):

Crystalline Parameters $(\stackrel{0}{A})$ :

Atomic Distance $(\stackrel{0}{A})$ :

Space Group:

Atoms per Unit Cell:
Tetraoxo-Lithium-Aluminate

$\mathrm{L} \cdot \mathrm{i}_{5} \mathrm{~A}: 10_{4}$

125.67

2.25

$\alpha$-phase

2.22

$\beta$-phase

0.62

0.61

$\alpha$-phase

B-phase

$\alpha$-phase:

low temp-phase - stable up to $750^{\circ}-800^{\circ} \mathrm{C}$

B-phase:

high temp-phase - stable from room temp. to decomposition point

$\alpha$-phase - ORTHORHOMBIC

$\beta$-phase - ORTHORHOMBIC

$\alpha$-phase

$$
\begin{aligned}
& \mathrm{a}=9.087 \\
& \mathrm{~b}=8.947 \\
& \mathrm{c}=9.120
\end{aligned}
$$

(Ref. 23)

$\beta$-phase

$$
\begin{aligned}
& a=6.42 \\
& b=6.30 \\
& c=4.62
\end{aligned}
$$

$($ Ref. 24)

unreported

3.34

A T -0

$\alpha$-phase

3.36

$\beta$-phase

Pbca

$\alpha$-phase

(Ref. 23)

Pmmn

$\beta$-phase

(Ref. 24)

Li

40

AT.

8

32

$\alpha$-phase

0
10

0

2

8

B-phase 
Figure 3.3.3 (Continued)

$X$-Ray Diffraction:

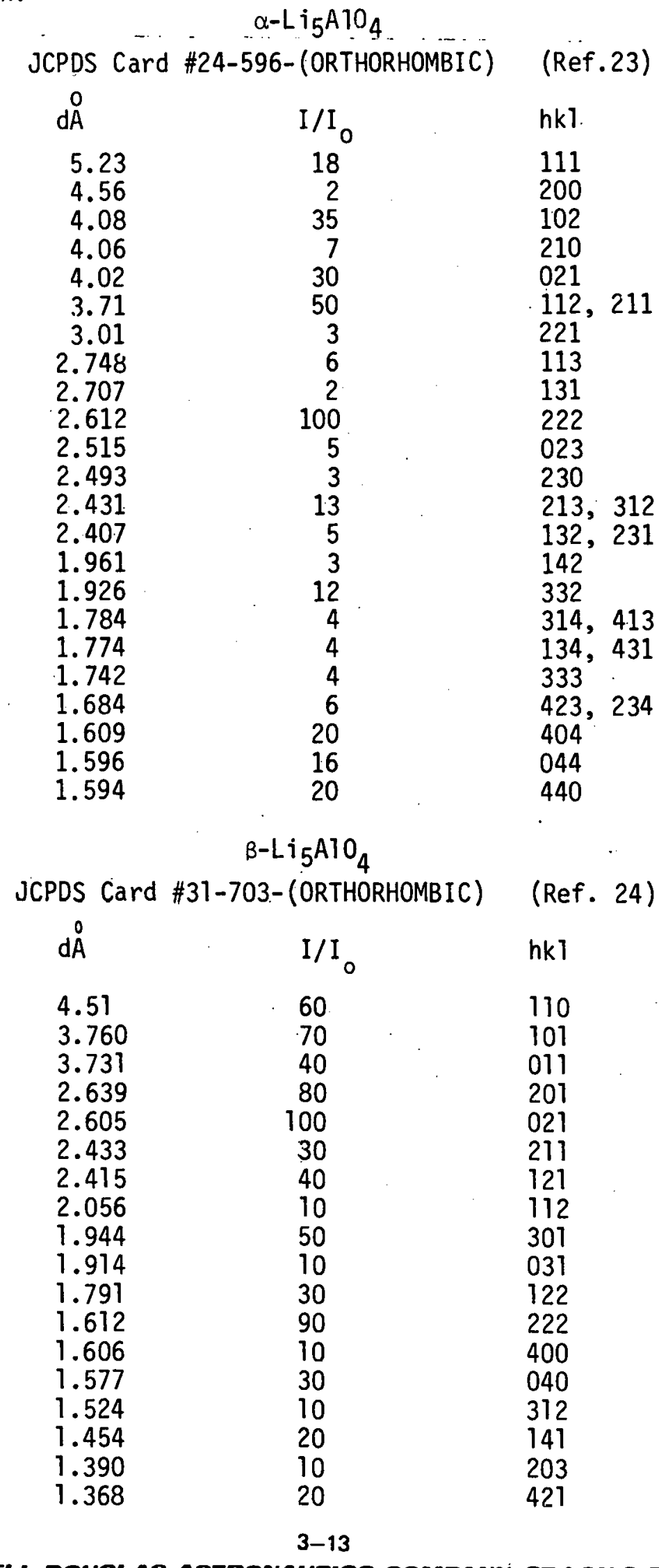




\section{$3.4 \mathrm{Li}_{2} \mathrm{O}-\mathrm{SiO}_{2}$ SYSTEM}

There have been five reported compounds in the $\mathrm{Li}_{2} \mathrm{O}-\mathrm{SiO}_{2}$ system: $\mathrm{Li}_{6} \mathrm{Si}_{2} \mathrm{O}_{7}$, $\mathrm{Li}_{4} \mathrm{SiO}_{4}, \mathrm{Li}_{2} \mathrm{SiO}_{3}, \mathrm{Li}_{2} \mathrm{Si}_{2} \mathrm{O}_{5}$ and $\mathrm{Li}_{2} \mathrm{Si}_{3} \mathrm{O}_{7}$. Of these, $\mathrm{Li}_{6} \mathrm{Si}_{2} \mathrm{O}_{7}$ and $\mathrm{Li}_{2} \mathrm{Si}_{3} \mathrm{O}_{7}$ have been found to be metastable and will not be extensively discussed here.

Völlenkle et al. (25) reported the formation of $\mathrm{Li}_{6} \mathrm{Si}_{2} \mathrm{O}_{7}$ by rapidly quenching to room temperature a $3 \mathrm{Li}_{2} \mathrm{O}: 2 \mathrm{SiO}_{2}$ melt $01300^{\circ} \mathrm{C}$ in air. They found that by cooling slowly from $1300^{\circ} \mathrm{C}$, no $\mathrm{Li}_{6} \mathrm{Si}_{2} \mathrm{O}_{7}$ formed but rather $\mathrm{Li}_{4} \mathrm{SiO}_{4}$ and $\mathrm{Li}_{2} \mathrm{SiO}_{3}$. In addition, if the quenched $\mathrm{Li}_{6} \mathrm{Si}_{2} \mathrm{O}_{7}$ material was reheated to $900^{\circ} \mathrm{C}$ for several hours, it would again form $\mathrm{Li}_{4} \mathrm{SiO}_{4}$ and $\mathrm{Li}_{2} \mathrm{SiO}_{3}$ phases with no trace of the original $\mathrm{Li}_{6} \mathrm{Si}_{2} \mathrm{O}_{7}$.

West and Glasser ${ }^{(26)}$ produced $\mathrm{Li}_{2} \mathrm{Si}_{3} \mathrm{O}_{7}$ from $1 \mathrm{Li}_{2} \mathrm{O}: 3 \mathrm{SiO}_{2}$ melt by cooling from $1400^{\circ} \mathrm{C}$ to $890^{\circ} \mathrm{C}$ and then to room temperature. If cooled directly from $1400^{\circ} \mathrm{C}$ to room temperature only $\mathrm{Li}_{2} \mathrm{Si}_{2} \mathrm{O}_{5}, \mathrm{SiO}_{2}$ and glass were seen. Al though stable at ambient temperatures, $\mathrm{Li}_{2} \mathrm{Si}_{3} \mathrm{O}_{7}$ was destroyed by prolonged heating (12-24 hours) above $650^{\circ} \mathrm{C}$. The decomposition products were $\mathrm{SiO}_{2}$ and $\mathrm{Li}_{2} \mathrm{Si}_{2} \mathrm{O}_{5}$.

Kracek $^{(27)}$ developed a partial phase diagram (Figure 3.4.1) concerning the three stable phases: $\mathrm{Li}_{4} \mathrm{SiO}_{4}, \mathrm{Li}_{2} \mathrm{SiO}_{3}$ and $\mathrm{Li}_{2} \mathrm{Si}_{2} \mathrm{O}_{5}$. Of these, lithium disilicate, $\mathrm{Li}_{2} \mathrm{Si}_{2} \mathrm{O}_{5}$, has been the most extensively studied since it is widely used in glass-ceramic applications. ${ }^{(28-30)}$ Unfortunately, it possesses both a low melting point $\left(1033^{\circ} \mathrm{C}\right)$ and lithium atom density $\left(0.22 \mathrm{~g} / \mathrm{cm}^{3}\right)$ and has not been actively considered as a solid breeder. The remaining two materials, lithium orthosilicate $\left(\mathrm{Li}_{4} \mathrm{SiO}_{4}\right)$ and lithium metasilicate $\left(\mathrm{Li}_{2} \mathrm{SiO}_{3}\right)$, have received consideration.

Figure 3.4.1 reveals that $\mathrm{Li}_{4} \mathrm{SiO}_{4}$ decomposes at $1255^{\circ} \mathrm{C}$ rather than merely. melting and that a loss of $\mathrm{Li}_{2} \mathrm{O}$ from $\mathrm{Li}_{4} \mathrm{SiO}_{4}$ allows liquid phase formation at $1024^{\circ} \mathrm{C} . \quad \mathrm{Li}_{2} \mathrm{SiO}_{3}$ melts at $1201^{\circ} \mathrm{C}$ and any loss or gain of $\mathrm{Li}_{2} \mathrm{O}$ will result in some liquid phase formation at $1033^{\circ} \mathrm{C}$ and $1024^{\circ} \mathrm{C}$ respectively.

This diagram does not show any phase transitions for either $\mathrm{Li}_{4} \mathrm{SiO}_{4}$ or $\mathrm{Li}_{2} \mathrm{SiO}_{3}$ but West and Glasser $(31,32)$ reported a crystallographic transformation for 


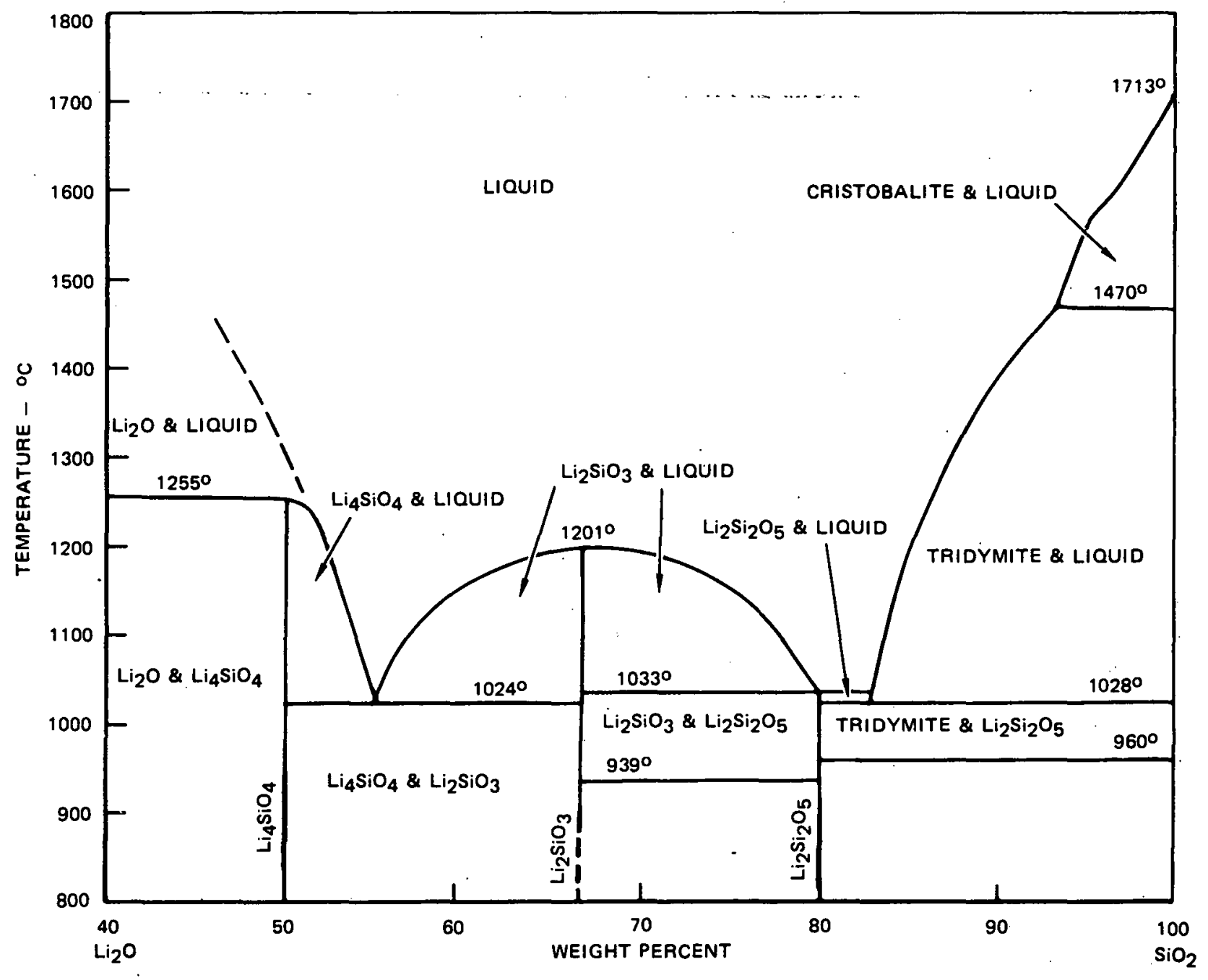

13-6104

FIgURE 3.4.1 PARTIAL PHASE DIAGRAM OF THE SYSTEM $\mathrm{Li}_{2} \mathrm{O}-\mathrm{SiO}_{2}$

$\mathrm{Li}_{4} \mathrm{SiO}_{4}$ @ $666^{\circ} \mathrm{C}$. Although studying the $\mathrm{Li}_{4} \mathrm{SiO}_{4}-\mathrm{Zn}_{2} \mathrm{SiO}_{4}$ system, they used DTA and high temperature $x$-ray diffraction to identify a transformation in "pure" $\mathrm{Li}_{4} \mathrm{SiO}_{4}$. Their results indicate a reversible transformation accompanied by a crystal change which usually is a severe volume change for the material. This transformation process would severely limit the usefulness of a sintered, $\mathrm{Li}_{4} \mathrm{SiO}_{4}$ body without crack initiation. Their paper did not mention the chemical or phase purity of the $\mathrm{Li}_{4} \mathrm{SiO}_{4}$ used in their study, which could have affected their results. The work presented by $\mathrm{Hollenberg}^{(33)}$ on a $\mathrm{Li}_{4} \mathrm{SiO}_{4}$ sample slightly contaminated with $\mathrm{Li}_{2} \mathrm{SiO}_{3}$ indicated a reversible transformation (a) $665^{\circ} \mathrm{C}$ but one that was displacive instead of crystallographic. Displacive transformations require some movement or rotation of atoms within the structure but don't result in a large volume change that occurs during crystallographic transformations. This finding allayed fears of a phase change which 
would crack a sintered, $\mathrm{Li}_{4} \mathrm{SiO}_{4}$ body. when heated beyond the transformation temperature.

Crystallographic information concerning $\mathrm{Li}_{4} \mathrm{SiO}_{4}$ is listed in Figure 3.4.2. The lattice parameters of monoclinic $\mathrm{Li}_{4} \mathrm{SiO}_{4}$ have been determined by numerous investigators. (35-37) Most are fairly close except for Tranqui et a1: (34) who used a super lattice to explain some of the slight irregularities seen by earlier investigators. The $\mathrm{Li}_{4} \mathrm{SiO}_{4}$ crystal structure contains isolated [ $\mathrm{SiO}_{4}$ ] tetrahedra being connected by edge and corner sharing with $\left[\mathrm{LiO}_{4}\right],\left[\mathrm{LiO}_{5}\right]$, and $\left[\mathrm{LiO}_{6}\right]$ polyhedra. The positions of the lithium atoms are only partially occupied. Tranqui et al. (34) expanded the unit cell to include $14 \mathrm{Li}_{4} \mathrm{SiO}_{4}$ formula units instead of the previously described $2 \mathrm{Li}_{4} \mathrm{SiO}_{4}$ formula units to eliminate differences between earlier investigators. The higher temperature form of $\mathrm{Li}_{4} \mathrm{SiO}_{4}$ proposed by West and Glasser ${ }^{(32)}$ has been classified as pseudo-orthorhombic but is fairly close to being tetragonal. Hollenberg's (33) high temperature $x$-ray diffraction patterns revealed that the transformation on the $\mathrm{Li}_{4} \mathrm{SiO}_{4}$ crystal structure involved a slight distortion of atoms in the lattices without breaking any bonds. Above the transformation temperature, he found that the $c$ parameter decreased while the a and b lattice parameters increased, thus allowing the high temperature phase to be merely a derivative of the starting material with only a small volume change.

Lithium metasilicate, $\mathrm{Li}_{2} \mathrm{SiO}_{3}$; has a slightly lower melting point $\left(1201^{\circ} \mathrm{C}\right)$ than that of $\mathrm{Li}_{4} \mathrm{SiO}_{4}$ and a lower 1 ithium atom density $\left(0.39 \mathrm{~g} / \mathrm{cm}^{3}\right.$ ) but undergoes no phase transitions during the path to its melting point." Figure 3.4 .3 contains its available crystallographic data. The crystal structure for $\mathrm{Li}_{2} \mathrm{SiO}_{3}$ can be described as $\left[\mathrm{SiO}_{4}\right]$ tetrahedra forming chains parallel to the c-axis with two tetrahedra in the unit cell. The tetrahedra are joined at the corners with the lithium atoms linking the chains together in the $a$ and $b$ directions. This positioning results in the lithium atoms being in tetrahedral coordination. 
Name:

Molecular Weight:

Density $\left(\mathrm{g} / \mathrm{cm}^{3}\right.$ ( ) $\left.298 \mathrm{~K}\right)$ :

Lithium Atom Density $\left(\dot{\mathrm{g}} / \mathrm{cm}^{3}\right)$ :

Crystalline Phase(s):

Crystalline Phase(s):

Crystalline Structure(s):

Crystalline Parameters $(\AA)$ :
Formula:

Figure 3.4 .2

Lithium Orthosilicate

$\mathrm{Li}_{4} \mathrm{SiO}_{4}$

119.84

2.39 $\alpha$-phase

$2.21 \quad \gamma$-phase

$0.55 \quad 0.51$

$\alpha$-phase $\gamma$-phase

a-phase - low temp. phase - stable until reversible displacive transformation (a) $665^{\circ} \mathrm{C}$ (Ref. 33)

$\gamma$-phase high temp. phase - stable only above $665^{\circ} \mathrm{C}$

$\alpha$-phase; MONOCLINIC

$\gamma$-phase; PSEUDO-ORTHORHOMBIC

$\alpha$-phase; MONOCLINIC

$\gamma$-phase; PSEUDO-ORTHORHOMBIC

$\alpha$-phase

$\begin{array}{llllll}\text { a } & 11.546 & 5.14 & 5.296 & 5.25 & 5.16 \\ \text { b } & 6.090 & 6.10 & 6.099 & 6.15 & 6.12 \\ \text { c } & 16.645 & 5.30 & 5.148 & 5.33 & 5.30 \\ \text { B } & 99.5 & 90.5 & 90.31 & 91.0 & 90.1 \\ & (\operatorname{Ref.34)} & \text { (Ref.35) } & \text { (Ref.34) } & \text { (Ref.36) } & \text { (Ref.37) }\end{array}$

$\gamma$-phase

$\begin{array}{llll}\text { a } & 5.30 & 5.23 & 5.24 \\ \text { b } & 6.32 & 6.32 & 6.14 \\ \text { c } & 5.45 & 5.45 & 5.52 \\ \text { B } & 90.8 & 90.35 & \\ & (\operatorname{Ref.32)} & (\operatorname{Ref.38}) & (\operatorname{Ref.38})\end{array}$

Atomic Distance $(\AA)$ :

Space Group:

$\mathrm{P} 2_{1} / \mathrm{m}$

$\mathrm{Si}-0$

1.632

Li-0

1.975

2.099

2.247

Li coord. \#4

$\alpha$-phase

(Ref. 35)

$\alpha$-phase

$\gamma$-phase

(Ref. 35)

Atoms per Unit Cell:

$\begin{array}{lll}8 & 56 & 8 \\ 2 & 14 & 2 \\ 8 & 56 & 8 \\ \alpha \text {-phase } & \alpha \text {-phase } & \gamma \text {-phase } \\ \text { (Ref.35) } & \text { (Ref.34) }\end{array}$


Figure 3.4.2. (Continued)

X-Ray Diffraction:

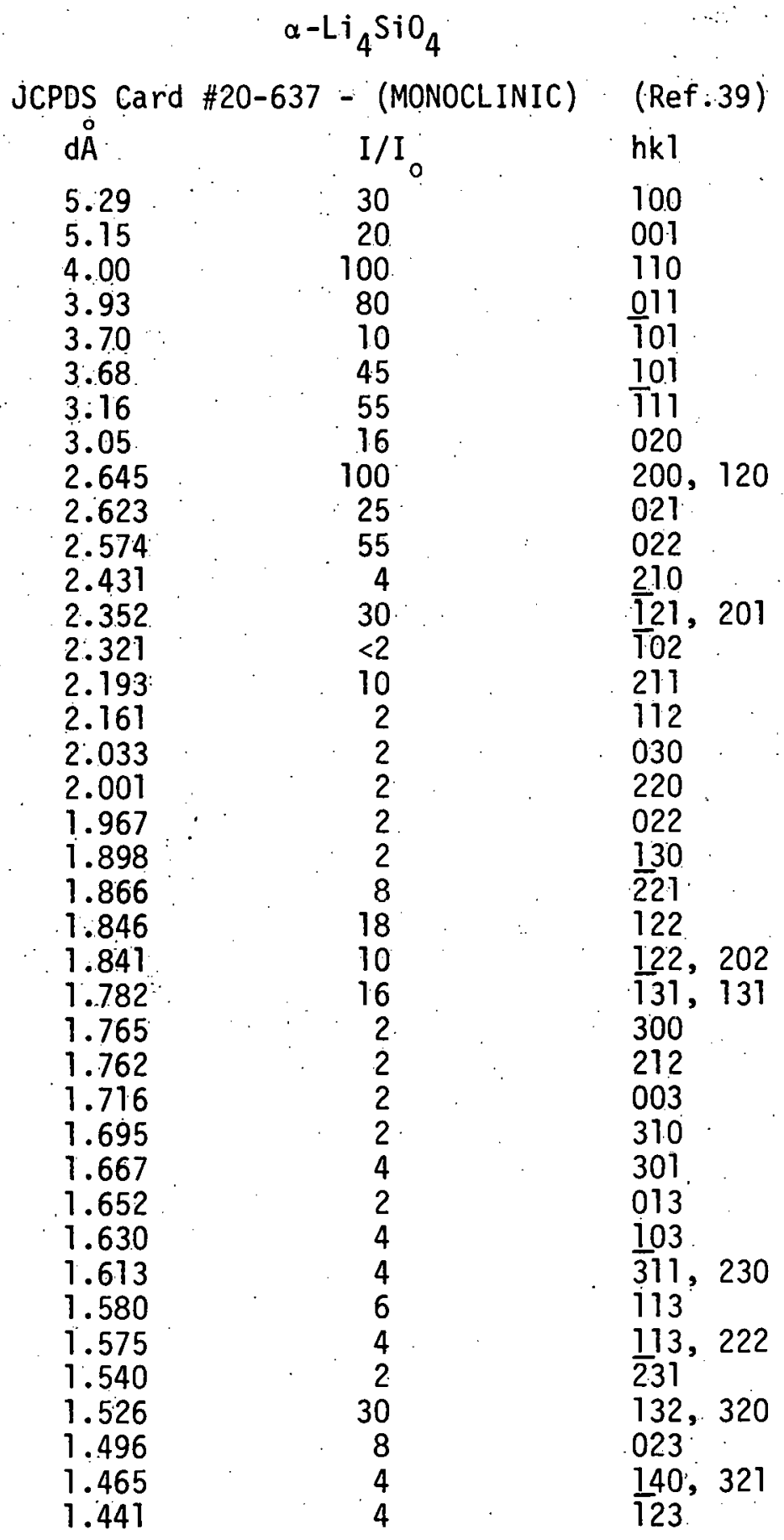

There were 11 more $d$-spacings with relative intensities $\left(\mathrm{I}_{\mathrm{I}} \mathrm{I}_{0}\right)<10$. 
LITHIUM BASED OXIDE CERAMICS FOR TRITIUM BREEDING APPLICATIONS

Report MDC E2677

Figure 3.4 .3

Name:

Formula:

Molecular Weight:

Density $\left(\mathrm{g} / \mathrm{cm}^{3}\right.$ (a $\left.298 \mathrm{~K}\right)$ :

Lithium Atom Density $\left(\mathrm{g} / \mathrm{cm}^{3}\right)$ :

Crystalline Phase(s):

Crystalline Structures):

Crystalline Parameters $(\stackrel{A}{A})$ :

Atomic Distance $(\AA)$ :

Space Group:

Atoms per Unit Cell:
Lithium Metasilicate

$\mathrm{Li}_{2} \mathrm{SiO}_{3}$

89.96

2.53

0.39

Single phase

ORTHORHOMBIC

$\begin{array}{llll}\text { a } & 5.3975 & 9.392 & 5.43 \\ \text { b } & 9.3974 & 5.397 & 9.41 \\ \text { c } & 4.6615 & 4.660 & 4.66 \\ & \text { (Ref } 40) & \text { (Ref } & 41 \text { ) }\end{array}$

(Ref. 40) (Ref. 41) (Ref. 42)

Li -0 2.00

$\begin{array}{ll}\text { Si -0 } & 1.636 \\ & \text { (Ref. 41) }\end{array}$

Cmc2 1

(Ref. Hl)

$\begin{array}{lr}\text { Li } & 8 \\ \text { Si } & 4 \\ 0 & 12\end{array}$

(Ref. 42)

$3-19$

DIvision 
Figure 3.4.3 (Continued)

X-Ray Diffraction:

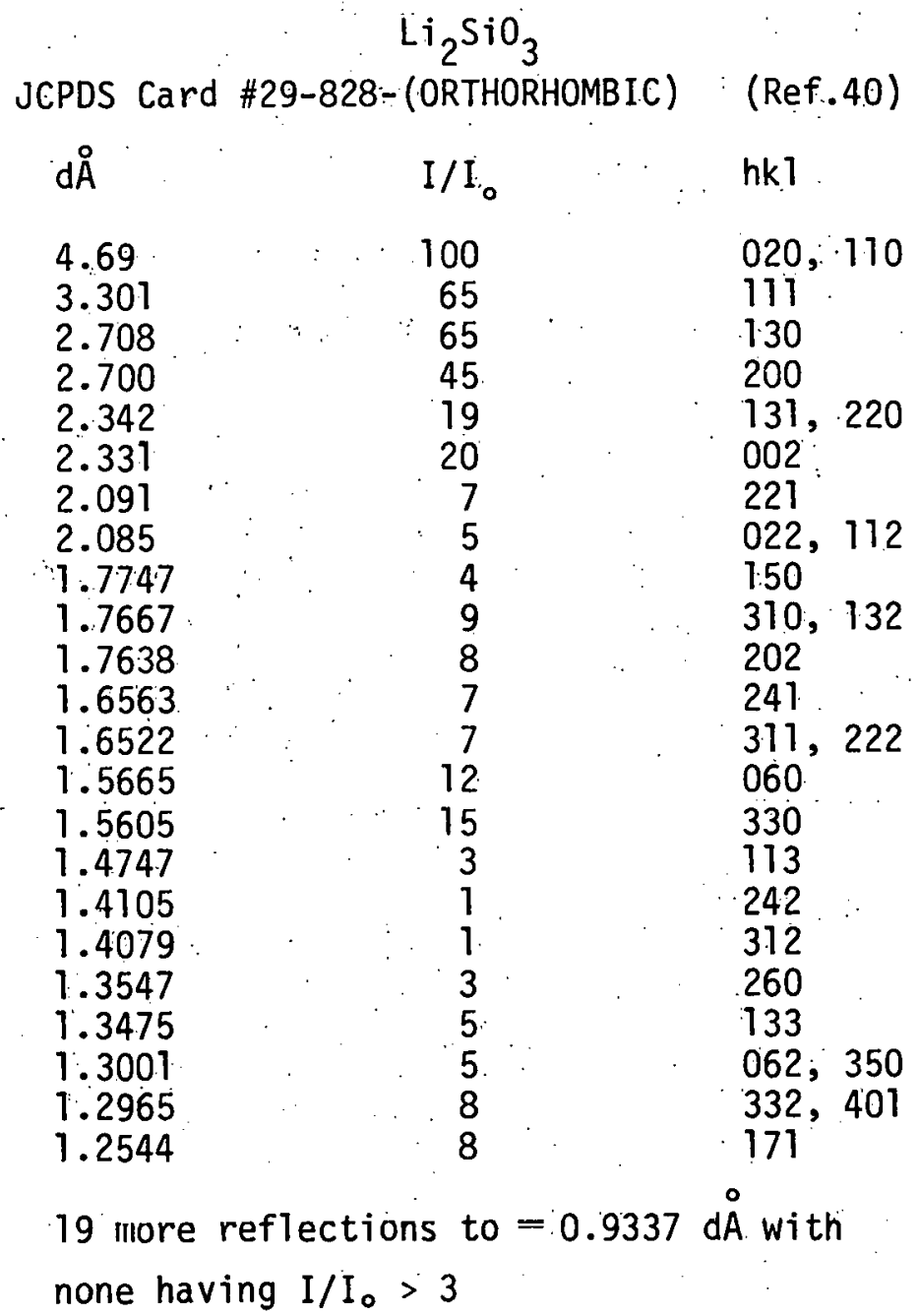




\section{$3.5 \mathrm{Li}_{2} \mathrm{O}-\mathrm{TiO}_{2}$ SYSTEM}

A partial phase diagram of the system $\mathrm{Li}_{2} \mathrm{O}-\mathrm{TiO}_{2}$, shown in Figure 3.5 .1 , has been constructed from the work of Gicquel et al., (43) Hummel and Tien, (44) and Mikkelsen, Jr. ${ }^{(45)}$ Although not all indicated on the diagram, numerous $\mathrm{Li}_{2} \mathrm{O}-\mathrm{TiO}_{2}$ compounds have been reported: $\mathrm{Li}_{4} \mathrm{TiO}_{4}, \mathrm{Li}_{2} \mathrm{TiO}_{3}, \mathrm{LiTiO}_{2}, \mathrm{LiTi}_{2} \mathrm{O}_{4}, \mathrm{Li}_{2} \mathrm{Ti}_{3} \mathrm{O}_{7}$, $\mathrm{Li}_{4} \mathrm{Ti}_{5} \mathrm{O}_{12}$ and $\mathrm{Li}_{2} \mathrm{Ti}_{2} \mathrm{O}_{5}$ to name a few. $\mathrm{Li}_{2} \mathrm{Ti}_{3} \mathrm{O}_{7}$ has been studied by Mikkelsen (45) who found that it melts $01300^{\circ} \mathrm{C}$ but decomposes eutectoidally $0940^{\circ} \mathrm{C}$. In addition $\mathrm{Li}_{4} \mathrm{Ti}_{5} \mathrm{O}_{12}$ was shown to decompose $01000^{\circ} \mathrm{C}$. The other materials, $\mathrm{LiTiO}_{2}$, $\mathrm{LiTi}_{2} \mathrm{O}_{4}$ and $\mathrm{Li}_{2} \mathrm{Ti}_{2} \mathrm{O}_{5}$ possess both low melting points and lithium atom densities and will not be considered further.

According to Figure $3.5 .1, \mathrm{Li}_{4} \mathrm{TiO}_{4}$ decomposes o $1200^{\circ} \mathrm{C}$ to $\mathrm{Li}_{2} \mathrm{TiO}_{3}$ and a 1 iquid, while any additions of $\mathrm{Li}_{2} \mathrm{O}$ to $\mathrm{Li}_{4} \mathrm{TiO}_{4}$ lower the temperature of initial liquid phase formation to $1030^{\circ} \mathrm{C}$. A eutectic exists at $\approx 1030^{\circ} \mathrm{C}$ for a composition of 56 wt $\% \mathrm{Li}_{2} \mathrm{O}$ and $44 \mathrm{wt} \% \mathrm{TiO}_{2}$. Also indicated by the phase diagram is the $\alpha$ to $B$ phase transformation for $\mathrm{Li}_{4} \mathrm{TiO}_{4}$ a $670^{\circ} \mathrm{C}$. Dubey and West ${ }^{(46)}$ found the $\alpha$ to $\beta$ transformation to be reversible according to DTA results and with little volume change. The crystallographic data for $\mathrm{Li}_{4} \mathrm{TiO}_{4}$ is contained in Figure 3.5.2. The structure is built up by $\left[\mathrm{TiO}_{4}\right]$ tetrahedra being linked together by $\left[\mathrm{LiO}_{4}\right]$ tetrahedra, so both $\mathrm{Li}$ and $\mathrm{Ti}$ atoms are tetrahedrally coordinated by oxygen and all sites are fully occupied.

Al though not extensively studied, Dubey and West ${ }^{(46)}$ believed that $\mathrm{\beta}-\mathrm{Li}_{4} \mathrm{TiO}_{4}$ possessed a structure similar to the low temperature form of $\mathrm{Li}_{4} \mathrm{SiO}_{4}$ where the degree of occupancy by $L i$ atoms has changed as well as their coordinating numbers with $\left[\mathrm{LiO}_{4}\right],\left[\mathrm{LiO}_{5}\right]$ and $\left[\mathrm{LiO}_{6}\right]$ existing.

While $\mathrm{Li}_{2} \mathrm{TiO}_{3}$ has been found to melt $01535^{\circ} \mathrm{C}$, any shift in stoichiometry results in a liquid phase formation at lower temperatures. Increasing the $\mathrm{Li}_{2} \mathrm{O}$ concentration of $\mathrm{Li}_{2} \mathrm{TiO}_{3}$ will result in some 1 iquid being formed at $1200^{\circ} \mathrm{C}$ while a $\mathrm{Li}_{2} \mathrm{O}$ loss produces a liquid phase $01300^{\circ} \mathrm{C}$. A reversible $\beta$ to $\gamma$ phase transformation occurs at $1150^{\circ} \mathrm{C}$ although, in reality, $\mathrm{Li}_{2} \mathrm{TiO}_{3}$ has been found to have three allotropes: $\alpha, \beta$, and $\gamma$. The $\alpha$-phase was studied by Gicquel et al., (43) who found it to be only a metastable version which transforms to $\mathrm{B}-\mathrm{Li}_{2} \mathrm{TiO}_{3}$ upon heating above $300^{\circ} \mathrm{C}$. The $\mathrm{B}$-phase was found to be stable 


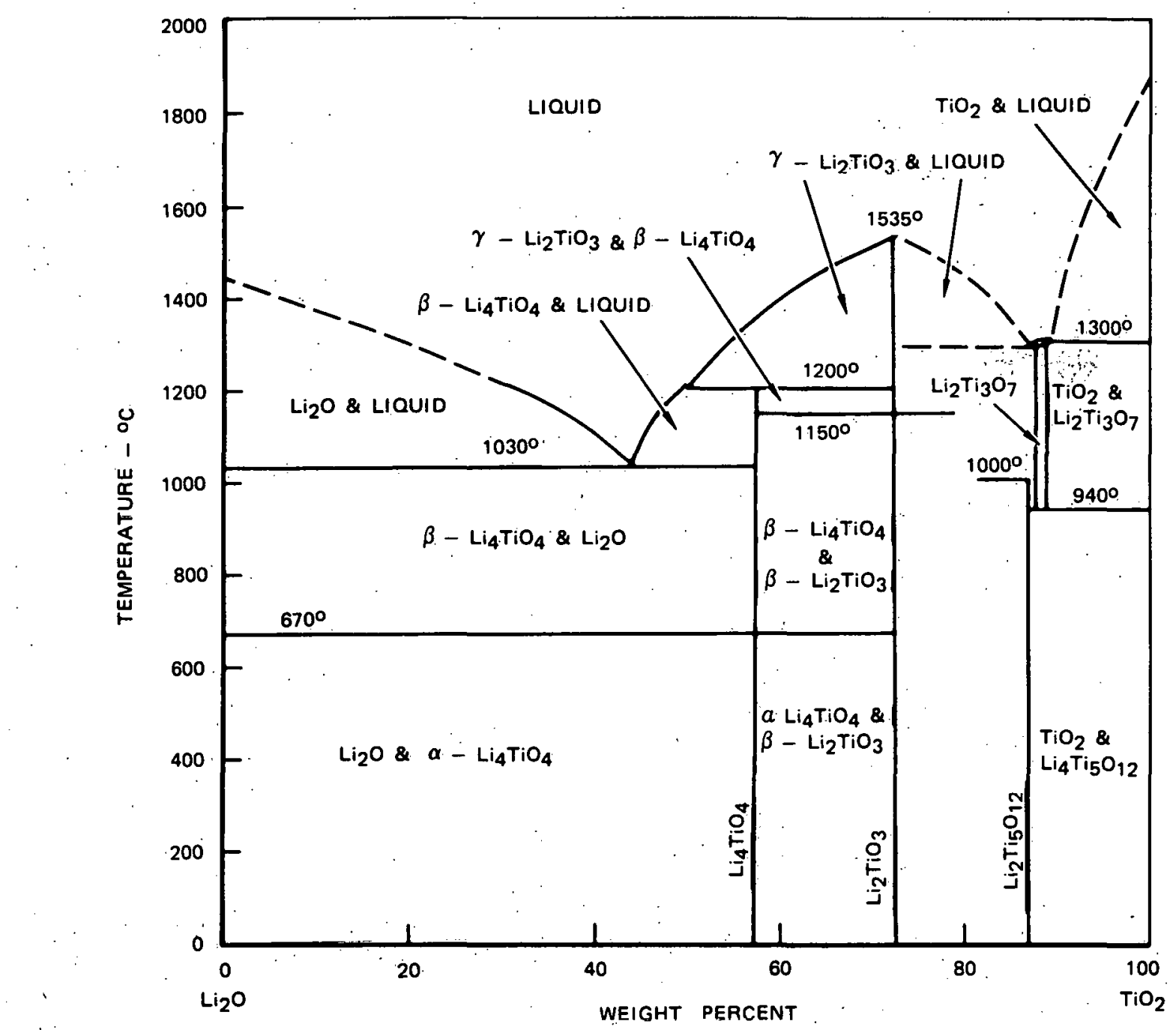

13-6106

figure 3.5.1 PARTIAL PHASE DIAGRAM OF THE SYSTEM $\mathrm{Li}_{2} \mathrm{O}-\mathrm{TiO}_{2}$ 
Figure 3.5 .2

Name:

Formula:

Molecular Weight:

Density $\left(\mathrm{g} / \mathrm{cm}^{3}\right.$ o $\left.298 \mathrm{~K}\right)$;

Lithium Atom Density $\left(\mathrm{g} / \mathrm{cm}^{3}\right)$ :

Crystalline Phase(s):

Crystalline Structure(s):

Crystalline Parameters $(\stackrel{\circ}{\AA})$ :

Atomic Distance $(\stackrel{\circ}{A})$ :

Space Group:

Atoms per Unit Cell:
Lithium Orthotitanate

$\mathrm{Li}_{4} \mathrm{TiO}_{4}$

139.65

$2.57 \quad \begin{aligned} & \alpha \text {-phase } \\ & \beta \text {-phase }\end{aligned}$

0.51

$\alpha$-phase $\beta$-phase

$\alpha$-phase; stable until reversible transformation 0.670 (Fief. 47)

B-phase; only stable above $670^{\circ} \mathrm{C}$

$\alpha$-phase; ORTHORHOMBIC

B-phase

$\alpha$-phase
$a=7.91$ (Ref. 47)
$b=6.15$
$c=7.41$

$\beta$-phase Not reported

Ti-O
Li-O

1.77

1.98

$\alpha$-phase

(Ref. 48)

Bmmb

$\alpha$-phase

$\beta$-phase

B-phase

Li

$\mathrm{Ti}$

0

16

16

$\gamma$-phase $\quad B$-phase

(Ref. 48) 
Figure 3.5.2 (Continued)

X-Ray Diffraction. Data:

\begin{tabular}{|c|c|c|}
\hline JCPDS Card & $\begin{array}{c}\alpha-\mathrm{Li}_{4} \mathrm{TiO}_{4} \\
\# 26-1197-(\text { ORTHORHOMBIC) }\end{array}$ & (Ref. 47) \\
\hline $\mathrm{d} \AA$ & $\mathrm{I} / \mathrm{I}_{0}$ & hkl \\
\hline $\begin{array}{l}5.41 \\
4.07 \\
3.95 \\
3.71 \\
3.18 \\
3.07 \\
2.71 \\
2.67 \\
2.47 \\
2.42 \\
2.36 \\
2.31 \\
2.27 \\
1.976 \\
1.914 \\
1.873 \\
1.805 \\
1.750\end{array}$ & $\begin{array}{r}50 \\
50 \\
30 \\
10 \\
40 \\
20 \\
100 \\
50 \\
20 \\
10 \\
10 \\
30 \\
10 \\
20 \\
20 \\
30 \\
20 \\
10\end{array}$ & $\begin{array}{l}101 \\
111 \\
200 \\
002 \\
012 \\
020 \\
202 \\
121 \\
212 \\
220 \\
103 \\
311 \\
113 \\
400 \\
131 \\
123 \\
303 \\
402\end{array}$ \\
\hline
\end{tabular}

to $1150^{\circ} \mathrm{C}$ where the reversible $\gamma$-transformation occurs. Detailed high temper: ature work has not been done on the $\gamma$-phase so an $x$-ray pattern is not known. The $\beta$-phase of $\mathrm{Li}_{2} \mathrm{TiO}_{3}$ is considered to be a derivative of the $\mathrm{NaCl}$ structure, with the oxygen atoms occupying the $\mathrm{Cl}$ ions sites and the lithium and titanium atoms occupying the Na sites in octahedral coordination. Further crystallographic data are listed in Figure 3.5.3. A disagreement exists over the correct $x$-ray diffraction pattern for $\beta-L i_{2} \mathrm{TiO}_{3}$ between the JCPDS version: given by Lang $(50)$ and Dorrian: ${ }^{(49)}$ Liebert $(51)$ further refined his measurements and showed that Dorrian's work was the more acceptable. Both Lang's $(50)$ and Liebert's ${ }^{(51)}$ patterns have been listed for comparison purposes. 
Figure 3.5 .3

Name:

Formula:

Molecular Weight:

Density $\left(\mathrm{g} / \mathrm{cm}^{3}\right.$ (อ 298K):

Lithium Atom Density $\left(\mathrm{g} / \mathrm{cm}^{3}\right)$ :

Crystalline Phase(s):

Crystalline Structure(s):

Crystalline Parameters $(\stackrel{\circ}{A})$ :

Atomic Distance $(\stackrel{\circ}{A})$ :

Space Group:

Atoms per Unit Cell:
Lithium Metatitanate

$\mathrm{Li}_{2} \mathrm{TiO}_{3}$

109.78

$2.00 \quad \alpha$-phase

$3.43 \quad \beta$-phase

$2.57 \quad \gamma$-phase

$\begin{array}{lll}0.25 & 0.43 & 0.32\end{array}$

$\alpha$-phase $\quad \beta$-phase $\gamma$-phase

$\alpha$-phase - metastable ${ }^{\text {converts irreversibly }}$

$\beta$-phase - stable from R.T. to $1150^{\circ} \mathrm{C}$ where a reversible transformation to $\gamma$ occurs

$\gamma$-phase - stable above $1150^{\circ} \mathrm{C}$

$\alpha$-phase - CUBIC

$\beta$-phase - MONOCLINIC

$\gamma$-phase - CUBIC

$\alpha$-phase

$a=4.50 \quad($ Ref. 43)

B-phase

$\mathrm{a}=5.041 \quad 5.05$

$\mathrm{b}=8.806 \quad 8.76$

$c=9.726 \quad 28.60$

$\beta=100^{\circ} 01^{\prime} .100 .0$

(Ref. 49) (Ref. 50)

$\gamma$-phase

$\mathrm{a}=4.1355 \quad$ (Ref. 45)

Li -0

$\mathrm{Ti}-0$

2.14

1.95

$\alpha$-phase $\quad \beta$-phase : $\gamma$-phase

Not reported $\alpha$-phase

$\mathrm{C} 2 / \mathrm{c}$

Not reported $\gamma$-phase

$\begin{array}{cccccc}\mathrm{Li} & 2 & 16 & 40 & 2 \\ \mathrm{Ti} & 1 & 8 & \text { or } & 27 & 1 \\ 0 & 3 & 24 & & 72 & 3 \\ & \alpha-\text {-phase } & \vdots & \beta \text {-phase } & \gamma \text {-phase } \\ & \text { (Ref. 43) } & \text { (Ref. 49) (Ref. 50) } & \text { (Ref. 45) }\end{array}$ 
Figure 3.5.3 (Continued)

X-Ray Diffraction:

\begin{tabular}{|c|c|c|c|c|c|}
\hline \multirow{2}{*}{$\begin{array}{l}\text { JCPDS Card } \\
\mathrm{d} \AA\end{array}$} & $\# 8-249-($ MONOCLINIC) & \multirow[t]{2}{*}{ (Ref.50) } & \multicolumn{3}{|c|}{ (MONOCLINIC) (Ref. 51) } \\
\hline & $\mathrm{I} / \mathrm{I}_{0}$ & & $\mathrm{~d} A$ & $\mathrm{I} / \mathrm{I}_{\mathrm{o}}$ & $h k 1$ \\
\hline 4.76 & 50 & 006 & $\begin{array}{l}4.784 \\
4.343 \\
4.211 \\
4.005 \\
3.739 \\
2.994\end{array}$ & $\begin{array}{c}71 \\
28 \\
11 \\
16 \\
6 \\
6\end{array}$ & $\begin{array}{l}002 \\
110 \\
012 \\
021 \\
112 \\
112\end{array}$ \\
\hline 2.481 & 30 & 202 & $\begin{array}{l}2.498 \\
2.390 \\
2.300\end{array}$ & $\begin{array}{r}52 \\
3 \\
5\end{array}$ & $\begin{array}{l}200 \\
004 \\
201\end{array}$ \\
\hline $\begin{array}{l}2.070 \\
1.896\end{array}$ & $\begin{array}{r}100 \\
5\end{array}$ & 208 & $\begin{array}{l}2.072 \\
1.909 \\
1.811 \\
1.598\end{array}$ & $\begin{array}{r}100 \\
15 \\
4 \\
29\end{array}$ & $\begin{array}{l}202 \\
230 \\
142 \\
006\end{array}$ \\
\hline $\begin{array}{l}1.592 \\
1.463 \\
1.396 \\
1.257 \\
1.242 \\
1.193 \\
1.157\end{array}$ & $\begin{array}{r}30 \\
100 \\
30 \\
5 \\
5 \\
75 \\
50\end{array}$ & $\begin{array}{l}2014,0018 \\
2016,060 \\
066 \\
402 \\
2020,0612 \\
0024,408 \\
2022,4010\end{array}$ & $\begin{array}{l}1.593 \\
1.465 \\
1.399 \\
1.263 \\
1.201 \\
1.195 \\
1.163\end{array}$ & $\begin{array}{r}29 \\
83 \\
17 \\
4 \\
14 \\
19 \\
11\end{array}$ & $\begin{array}{l}241 \\
312 \\
243 \\
304 \\
226 \\
420 \\
047\end{array}$ \\
\hline
\end{tabular}

\section{$3.6 \quad \mathrm{Li}_{2} \mathrm{O}-\mathrm{ZrO}_{2}$ SYSTEM}

Although no binary phase diagram exists for this system, several compounds have been reported: $\mathrm{Li}_{8} \mathrm{ZrO}_{5}, \mathrm{Li}_{4} \mathrm{ZrO}_{4}, \mathrm{Li}_{2} \mathrm{ZrO}_{3}$ and $\mathrm{Li}_{2} \mathrm{Zr}_{2} \mathrm{O}_{5}$. Work performed by $P$ lyushchev and Grizik ${ }^{(67)}$ revealed that $\mathrm{Li}_{2} \mathrm{Zr}_{2} \mathrm{O}_{5}$ was a metastable product and did not exist under normal conditions. Of the remaining three, only $\mathrm{Li}_{2} \mathrm{ZrO}_{3}$ has received much interest as a solid breeder.

The crystalline properties of $\mathrm{Li}_{8} \mathrm{ZrO}_{6}$ have been tabulated in Figure 3.6.1 but the work to date has been fairly limited. $\mathrm{Li}_{8} \mathrm{ZrO}_{6}$ has been reported by. several investigators ${ }^{(52-55)}$ but most have restricted themselves to the study of formation conditions and enthalpies. Larsen ${ }^{(56)}$ has examined several fused $\mathrm{Li}_{8} \mathrm{ZrO}_{6}$ samples and concluded that there are no phase transitions from room temperature to its melting point. Obviously since no phase diagram exists, the effect of departures from stoichiometry cannot be described. of major 
LITHIUM BASED OXIDE CERAMICS FOR TRITIUM BREEDING APPLICATIONS

Figure 3.6.1

Name:

Formula:

Molecular Weight:

Density $\left(\mathrm{g} / \mathrm{cm}^{3}\right.$ (a) $\left.298 \mathrm{~K}\right)$ :

Lithium Atom Density $\left(\mathrm{g} / \mathrm{cm}^{3}\right)$ :

Crystalline Phase(s):

Crystalline Structures):

Crystalline Parameters $(\AA)$ :

Atomic Distance $(\AA)$ :

Space Group:

Atoms per Unit Cell:
Octal lithium Zirconate

$\mathrm{Li}_{8} \mathrm{ZrO}_{6}$

242.73

3.01

0.69

Single phase

HEXAGONAL (Ref. 54)

$a=5.483$ (Ref. 54)

$c=15.45$

Li

2.14

(Ref. 54)

$\mathrm{R} \overline{3}$

$\begin{array}{lr}\mathrm{Li} & 24 \\ \mathrm{Zr} & 3 \\ 0 & 18\end{array}$

(Ref. 54)

Report MDC E2677

3-27

MCDONNELL DOUGLAS ASTRONAUTICS COMPANY-BT. LOUIS DIVISION 
Figure 3.6.1: (Continued)

X-Ray Diffraction:

$\begin{array}{ccc} & \mathrm{Li}_{8} \mathrm{ZrO}_{6} & \\ \text { JCPDS Card \#26-867-(HEXAGONAL) } & \text { (Ref. } 57 .) \\ 5.15 & 40 & 003 \\ 4.52 & 100 & 101 \\ 4.04 & 50 & 012 \\ 2.996 & 20 & 104 \\ 2.744 & 3 & 110 \\ 2.583 & 20 & 015,006 \\ 2.419 & 80 & 113 \\ 2.351 & 13 & 021 \\ 2.268 & 12 & 202 \\ 2.021 & 10 & 024 \\ 2.003 & 10 & 107 \\ 1.875 & 75 & 205,116 \\ 1.785 & 25 & 018,211 \\ 1.748 & 18 & 122 \\ 1.716 & 4 & 009 \\ 1.627 & 18 & 214 \\ 1.617 & 9 & 027 \\ 1.583 & 30 & 300 \\ 1.552 & 15 & 125 \\ 1.513 & 11 & 303 \\ 1.498 & 7 & 208 \\ 1.470 & 5 & 1010 \\ 1.456 & 18 & 119 \\ 1.393 & 11 & 217 \\ 1.371 & 2 & 220 \\ 1.348 & 7 & 306,0111 \\ 1.325 & 10 & 223 \\ 1.314: & 16 & 128,131 \\ 1.300 & 10 & 312,0210 \\ 1.287 & 4 & 0012 \\ 1.248 & 5 & 134 \\ 1.210 & 18 & 315,226+ \\ 1.185 & 4 & 401 \\ & & \end{array}$


importance would be the formation of a liquid phase. Tromel and Hauch studied the crystal structure of $\mathrm{Li}_{8} \mathrm{ZrO}_{6}$ and found it to be isostructural with $\mathrm{Li}_{8} \mathrm{SnO}_{6}$. The $\mathrm{Zr}^{4+}$ and $1 / 3$ of $\mathrm{Li}^{+}$atoms are octahedral coordinated by 0 atoms and these layers are separated in the c-direction by the remaining $2 / 3$ of the $\mathrm{Li}^{+}$atoms tetrahedrally coordinated. Delmar, et.al. ${ }^{(63)}$ verified this structure during ionic conductivity experiments on $\mathrm{Li}_{8} \mathrm{MO}_{6}(M=\mathrm{Zr}, \mathrm{Sn}), \mathrm{Li}_{7} \mathrm{LO}_{6}(\mathrm{~L}=\mathrm{Nb}, \mathrm{Ta})$ and $\mathrm{Li}_{6} \mathrm{In}_{2} \mathrm{O}_{6}$

The $\mathrm{Li}_{4} \mathrm{ZrO}_{4}$ composition has received even less interest than $\mathrm{Li}_{8} \mathrm{ZrO}_{6}$. Very little information exists on this material as even its melting point has not been published. The available crystallographic data are listed in Figure 3.6.2.

$\mathrm{Li}_{2} \mathrm{ZrO}_{3}$ possesses a high melting point $\left(1500^{\circ} \mathrm{C}\right)$ with a reversible monoclinic to tetragonal phase transition occurring $1100^{\circ} \mathrm{C}$. Since this is above the normal operating temperature limits of the breeding blanket, only the monoclinic form has received any interest. Its crystalline data are contained in

Figure 3.6.3. Since there is no phase diagram, the effect of any deviations from stoichiometry of the $\mathrm{Li}_{2} \mathrm{ZrO}_{3}$ is unclear. The structural arrangement of $\mathrm{Li}_{2} \mathrm{ZrO}_{3}$ is $\mathrm{NaCl}-\mathrm{like}$, with the oxygen atoms form a distorted cubic closepacked network and the cations occupying all octahedral sites present in this network. The cations $\left(\mathrm{Li}^{+}\right.$and $\left.\mathrm{Zr}^{4+}\right)$ are in the ratio 2:1 and are distributed such that any layer perpendicular to the c-axis is the same. 
LITHIUM BASED OXIDE CERAMICS FOR

TRITIUM BREEDING APPLICATIONS

Report MOC E2677

Figure 3.6.2

Name:

Formula:

Molecular Weight:

Density $\left(\mathrm{g} / \mathrm{cm}^{3}\right.$ o $\left.298 \mathrm{~K}\right)$ :

Lithium Atom Density $\left(\mathrm{g} / \mathrm{cm}^{3}\right)$ :

Crystalline Phase (s):

Crystalline Structure (s):

Crystalline Parameters $(\stackrel{\circ}{A})$ :

Atomic Distance $(\AA)$ :

Space Group:

Atoms per Unit Ce ll:
Lithium orthozirconate

$\mathrm{Li}_{4} \mathrm{ZrO}_{4}$

182.97

3.87

0.59

Only one reported

MONOCLINIC (Ref. 58)

$a=10.446 \quad$ (Ref. 58)

$\mathrm{b}=5.991$

$c=10.205$

$\beta=100.25^{\circ}$

Not reported

Cc

$\begin{array}{ll}\mathrm{Li} & 32 \\ \mathrm{Zr} & 8 \\ 0 & 32 \\ & \text { (Ref. 58) }\end{array}$

$3-30$

MCDONNELL DOUGLAS ASTRONAUTICS COMPANY-BT.LOUIS OMHEION 
Figure 3.6.2 (Continued)

X-Ray Diffraction:

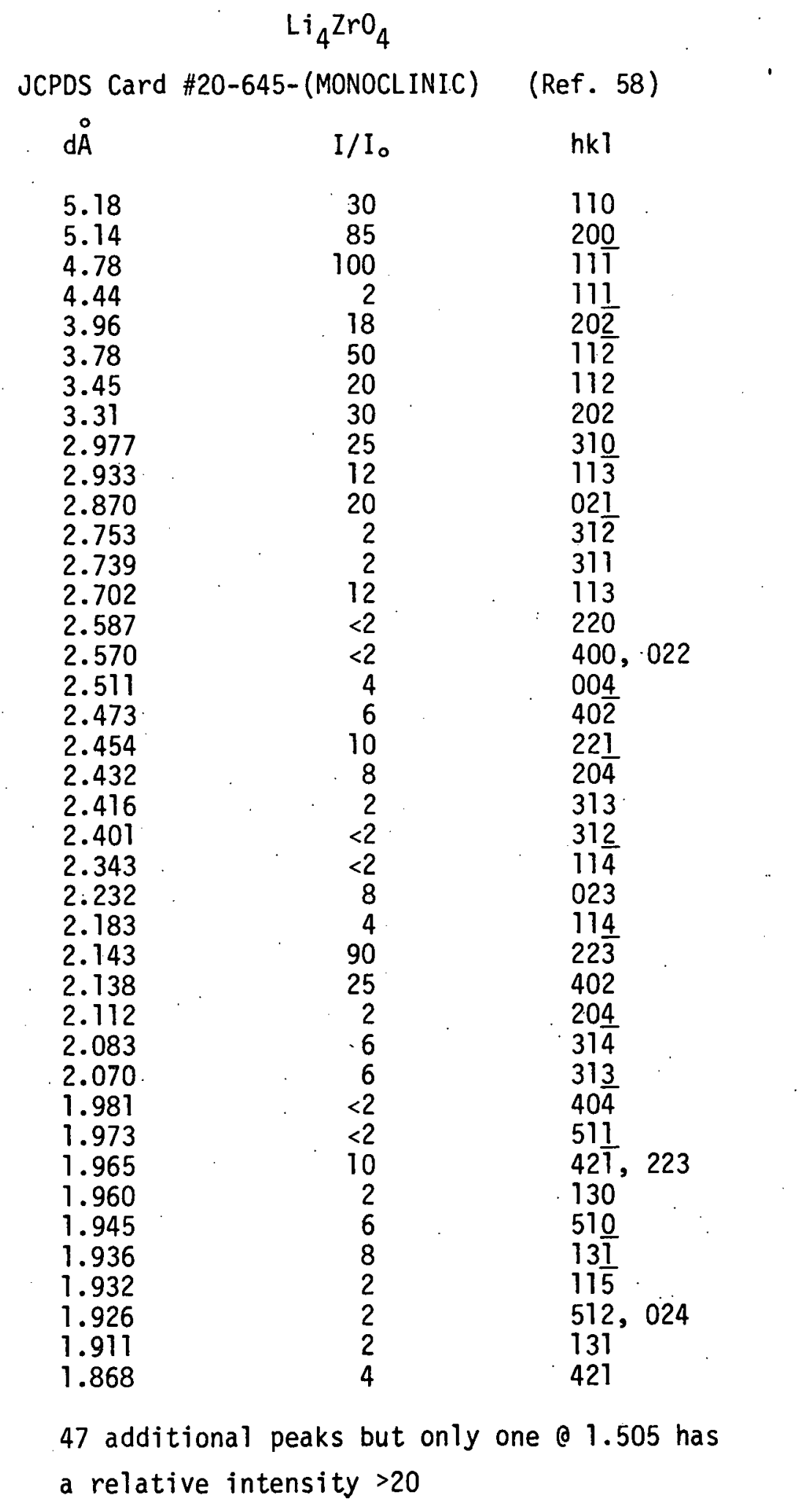


Figùre 3.6.3

Name:

Formula :

Molecular Weight:

Density $\left(\mathrm{g} / \mathrm{cm}^{3}\right.$ (0 $\left.298 \mathrm{~K}\right)$ :

Lithium Atom Density $\left(\mathrm{g} / \mathrm{cm}^{3}\right)$ :

Crystalline Phase.(s):

Crystal1ine Structure(s):

Crystalline Parameters $(\stackrel{\circ}{A})$ :

Atomic Distance (A):

Space Group:

Atoms per Unit Cell:
Lithium Metazirconate

$\mathrm{Li}_{2} \mathrm{ZrO}_{3}$

153.10

(monoclinic) 4.15

(tetragonal) 3.67

(monoclinic) 0.38

(tetragonal) 0.33

Monoclinic; only stable until $1100^{\circ} \mathrm{C}$ Tetragonal; only stable above $1100^{\circ} \mathrm{C}$

MONOCL.INIC TETRAGONAL

MONOCLINIC

$$
\begin{array}{ll}
a=5.427 & 5.422 \\
b=9.025 & 9.022 \\
c=5.427 & 5.419 \\
B=112.75^{\circ} & 112.709 \\
(\text { Ref. 59) } & (\text { Ref. 64) } \\
a=8.98 & \text { (Ref. 60) } \\
c=3.42 &
\end{array}
$$

TETRAGONAL

Avg.

3.06

2.22

2.10

MONO.

(Rẹf. 59)

$\mathrm{C} 2 / \mathrm{C}$

MONOCLINIC $\cdot(\operatorname{Ref} \cdot 64)$ TETRAGONAL

$\begin{array}{lcc}\operatorname{Li} & 8 & 8 \\ \mathrm{Zr} & 4 & 4 \\ 0 & 12 & 12 \\ & \text { Monoclinic } & \text { Tetragonal }\end{array}$


Figure 3.6.3 (Continued)

X-Ray Diffraction:

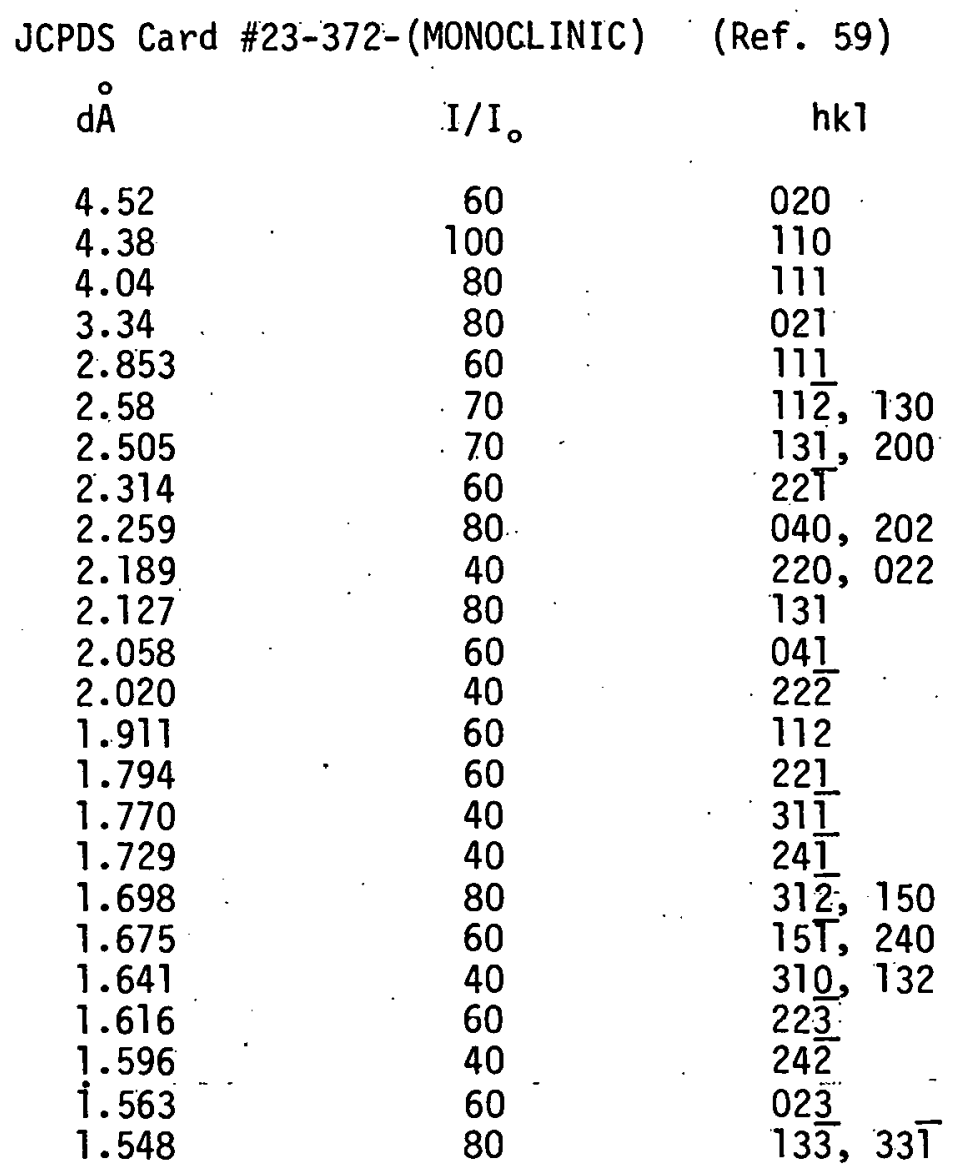


Figure 3.6 .3 (Continued)

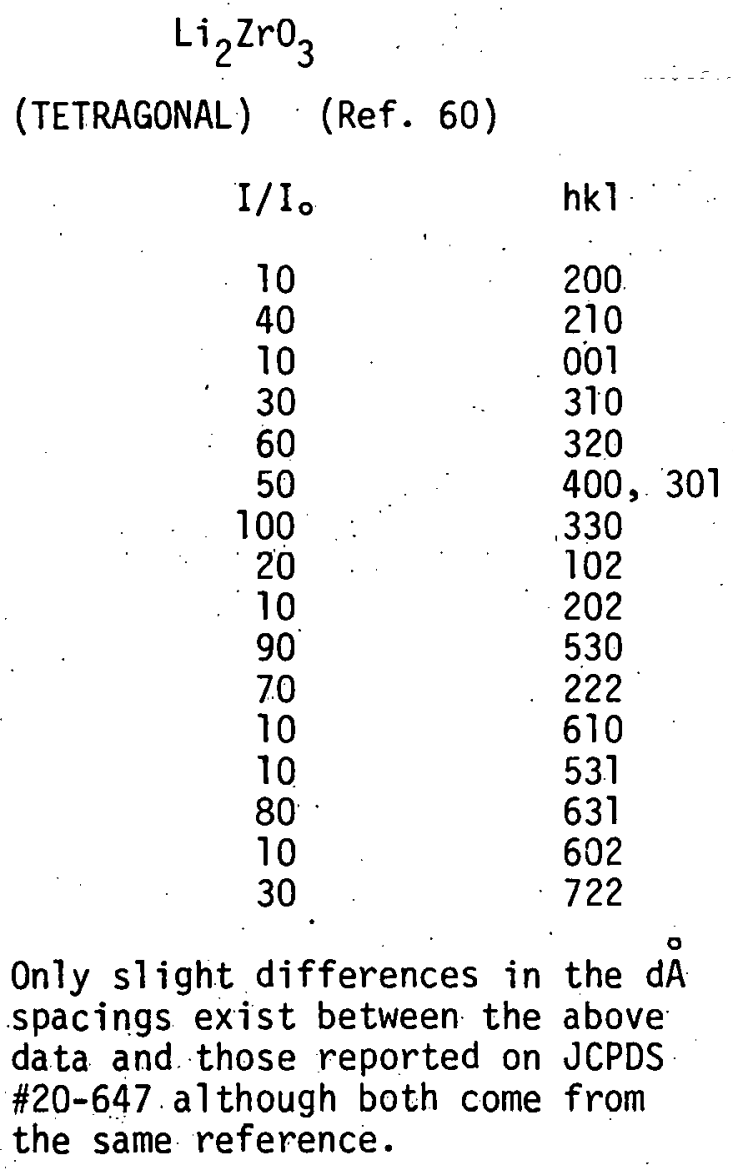

\subsection{REFERENCES}

(1) Schechter, W. H. and Kleinberg, J., J. Chem. Educ., 24, 302-303 (1947).

(2) Thompson, J. and Kleinberg, J., J. Am. Chem. Soc., 73, 1243-1245 (1951).

(3) Stecura, S., J. Less-Com. Metals, 33, 219-227 (1973).

(4) Foppl, H., Z. Anorg. Allg. Chem., 291, 12-15 (1957).

(5) Rode, T. V., Dobrynina, T. A., and Golder, G. A., Izv. Alead. Nauk SSSR, Otd. Khim. Nauk., 4, 611-621 (1955).

(6) Papin, G., Michaud, M., and Bouaziz, R., C. R. Acad. Sci., Paris, Ser. C, 268. (19), 1691-1693 (1969). 
(7) Smirnov, M. V., Lyubimtseva, I. Y., Tsiovkina, L. A., and Krasnov, Y. N., Russ. J. Inorg. Chem., 16(1), 130-133 (1971).

(8) Davis, J. W. (ed.), U.S. Dept. of Energy, DOE/ET-52039/1, 1-307 (1980).

(9) Swanson, H. E., Morris, M. C., Stinchfield, R. P., Evans, E. H., National Bureau Standards, Mono. 25, Ser. 1, 1-56 (1962).

(10) Masaki, N., Doi, K., Nasu, S., Tanifuji, T., and Uchida, K., J. Nucl. Mater., 84, 341-342 (1.979).

(11) Brewer, L. and Margrave, J., J. Phys, Chem., 59, 421-425 (1955).

(12) Pepinsky, R., Z. Krist, 102, 119-131 (1940).

(13) Zintl, E., Harder, A., and Davth, B., Z. Elektrochem., 40, 588-593 (1934).

(14) La Ginesta, A., Lo Jacono, M., and Porta, P., J. Therm. Anal., 4, 5-17 (1972).

(15) Lejus, A. M. and Collongues, R., Compt. Rend., 254, 2005-2007 (1962).

(16) Chang, C. H. and Margrave, J. L., J. Am. Chem. Soc., 90, 2020-2222 (1968).

(17) Dorhofer, J., J. Appl. Cryst., 12, 240-241. (1979).

(18) Lehmann, H. and Hesselbarth, H., Z. Anorg. Allg. Chem.,313, 117-121 (1961).

(19) Marezio, M. and Remeika, J., J. Chem. Phys.; 44, 3143-3144 (1966).

(20) Hummel, F. A., Sastry, B. S. R., and Wotring, D., J. Am. Cer. Soc., 4l(3), 88-92 (1958).

(21) Marezio, M., Acta Cryst., 19, 396-400 (1965).

(22) Guggi, D., Ihle, H. R., and Neubert, A., Proc. 9th Symposium on Fusion Technology, Garmisch-Partenkirchen.(FRG), Pergamon Press, pp. 635-644. (1976).

(23) Stewner, V. F. and Hoppe, R., Z. Anorg and Al1g. Chem., 380, 241-243 (1971).

(24) Hoppe, R. and Konig, H., Z. Anorg A11g. Chem, , 430, 211-217 (1977).

(25) Vollenkle, H., Wittman, A., and Nowotny, H., Monatsh. Chem., 1.00, 295-303 (1969).

(26) West, A. R. and Glasser, F. P., Mat. Res. Bu11., 5, 837-842 (1970).

(27) Kracek, F. C., J. Phys. Chem., 34 (1.2), 2641-2650 (1930).

(28) Doremus, R. H. and Turkalo, A. M., Phys. \& Chem. Glasses, 13(1), 14-19 (1972). 
(29) Freeman, S. W. and Hench, L. L., J. Am. Cer. Soc., 51 (7), 382-387 (1968).

(30) Phillips, S. V. and McMillan, P. W., Glass Technol., 6 (2), 46-51 (1965).

(31) West, A. R. and Giasser, F. P., J. Mater. Sci., 5, 557-565 (1970).

(32) West, A. R. and Glasser, F. P., J. Mater. Sci.; 5, 676-688 (1.970).

(33) Hollenberg, G. W., J. Nucl. Mater., 103-104, 591-596 (1981).

(34) Tranqui, D., Shannon, R. D., and Chen, H. Y., Acta Cryst., 35B, 24792487 (1979).

(35) Vollenkle, H., Wittmann, A., and Nowotny, H., Monatsh. Chem., 99, 1360-1371 (1968).

(36) Wittmann, A. and Modern, E., Monatsh. Chem., $\underline{96}(2), 581-582$ (1965).

(37) Dubey, B. L. and West, A. R., J. Inorg Nucl. Chem., 35, 3713-3717 (1973).

(38) Gratzer, W., Bittner, H., Nowotny, H., and Seifert, K., Z. Krist., 133, 260-263 (1.971).

(39) Powder Diffraction File, Card No. 20-637, Joint Committee on Powder Diffraction standards; Swarthmore, PA: (1979).

(40) : Powder Diffraction File, Card No. 29-828, Joint Committee on Powder Diffraction Standards, Swarthmore, PA (1979).

(41) Hesse, K., Acta. Crysta.; 33B, 901-902 (1977).

(42.) Donnay, G. and Donnay, J. D. H., Am. Minera1., 38, 163-171 (1953).

(43) Gicquel, C., Mayer, M., and Bouaziz, R., C. R. Acad, Sci., 275, $1427-1430(1972)$.

(44) Hummel, F. A. and Tien, T. Y., J. Am. Cer. Soc., 42, 206 (1959).

(45) Mikkelsen, Jr., J. C., J. Am. Cer. Soc., 8, 331-335 (1980).

(46) Dubey, B. L. and West, A. R., J. Inorg. Nucl. Chem., 35, 3713-3717 $(19.73)$.

(47) Dubey, B. L. and West, A. R., Nature Phy. Sci., 235, 155-1.56 (1972).

(48) Vollenkle, H. and Wittmann, A., Z. Kristallogr., 128, 66-71 (1969).

(49) Dorrian; J. F., "The Crystal Structure of $\mathrm{Bi}_{4} \mathrm{Ti}_{3} \mathrm{O}_{12}$ and $\mathrm{Li}_{2} \mathrm{TiO}_{3}$ ", PhD thesis, Pennsylvania State University, UMI-77-13, 844 (197T).

(50) Lang, G., Z. Anorg. Al1g. Chem.; 276, 77-94 (1954). 
(51) Liebert, B. E., "Evaluation of Lithium Titanates as Cathode Materials," Ph.D. thesis, Stanford University, UMI-78-2195 (1977).

(52) Scholder, V. R., Rade, D., and Schwarz, H., Z. Anorg. Allg. Chem., 362, 149-168 (1968).

(53) Neubert, A. and Guggi, D., J. Chem. Therm., 10, 297-306 (1.978).

(54) Hauck, J., Z. Naturforsch.; 24B, 1067-1068: (1969),

(55). Belyaev, E. K. and Annopoliskii, V. F., Russ. J. Inorg. Chem., 19(2), 297-299 (1974).

(56) Larsen, E. M. and Ortman, M. S., University of Wisconsin, UWFDM-449, $1-12(1982)$.

(57) Powder Diffraction File, Card No. 26-867, Joint Covmittee on Powder Diffraction Standards, Swarthmore, PA (1976).

(58) Powder Diffraction File, Card No. 20-645, Joint Committee on Powder Diffraction Standards, Swarthmore, PA (1976).

(59) Dittrich, G. and Hoppe, R., Z. Anorg. A11g. Chem., 371, 306-317 (1969).

(60) Kutolin, S. A. and Druz, N. A., Inorg. Mater., 1, 1457-1.453 (1965).

(61) Plyushchev, V. E. and Grizik, A. A., Russ. J. Inorg. Chem., ?(9), 10791084 (1962).

(62) Tromel, M. and Hauck, J., Z. Naturforsch., 23B, 110 (1968).

(63) Delmas, C., Maazaz, A., Guillen, F., Fouassier, C. Reau, J. M., and Hagenmulier, P., Mat. Res. Bu11., 14, 619-625 (1979).

(64) Hoseau, J. L., Marezio, Mi. Sântoro, A., and Roth, R. S., J. Solid State Chem. . $45,170-179$ (1982). 


\subsection{THERMAL PROPERTIES}

\subsection{INTRODUCTION}

The candidate breeders' response to temperature are important to the viability of proposed blanket designs. Critical properties include melting points, vaporization rates, thermal conductivity, specific heat and thermal expansion.

The solid breeder's melting point has influenced the upper-most operating limit in blanket designs. In general, \& $.6 T_{m} . p$. has been suggested as an upper bound due to sintering and grain growth at temperatures above this. The main concerns have involved the lengthening of the path for tritium bulk diffusion by grain growth and pore closure. This concern, however, has never been fully justified and while grain growth may occur at the higher temperatures, the increase in tritium diffusion kinetics may offset the longer path length and pore closure.

Vaporization rates become important as higher temperatures are reached or if the solid breeder is in contact with metal. Although most of the data has been generated using Pt knudsen cells, trends are still apparent. In actual blanket operation, Li transport, in some form, is more likely to occur from the "hotter" areas to "cooler" ones but still stay within the pellet or body itself rather than being deposited on metal surfaces or leaving in a purge gas stream.

Thermal conductivity values are needed to predict the coolant flows necessary to keep the solid breeder's temperature within the desired limits. The effect of irradiation (i.e. swelling, microcrack, etc.) may alter this property and will have to be taken into account. Presently, no post irradiation thermal conductivity measurements have been made on solid tritium materials although some have been planned.

Specific heat data are required to convert thermal diffusivity into more usable thermal conductivity values. In general, specific heats for ceramic systems increase from a low value at low temperatures to a value near $5.96 \mathrm{cal} /$ $\mathrm{g}$-atom ${ }^{\circ} \mathrm{C}$ at temperatures in the neighborhood of $1000^{\circ} \mathrm{C}$. Further increases in 
temperature do not strongly affect this value unless there are phase transitions, which result in abrupt changes in the specific heat curve.

Thermal expansion data are used in coolant calculations whereby the solid breeder is cooled to maintain desired, predictable, operating temperatures. If the solid breeder is encapsulated and cooled by being in contact with "cooled" metal, then it becomes important to know if the ceramic will "pull away" from the metal as both expand and lose cooling efficiency. If gap cooling is employed, the thermal expansions of both metal and ceramic are examined to insure there is a sufficient distance between solid breeder and metal to allow the coolant gas to be effective.

\subsection{MELTING POINT}

A major disagreement over the exact melting point of a solid breeder candidate, $\mathrm{Li}_{2} \mathrm{O}$, has existed for many years. The reporting of values from $1427^{\circ} \mathrm{C}$ to $1732^{\circ} \mathrm{C}(1-7)$ resulted in considerable uncertainty as to its exact melting point. The wide variance has probably been the result of the extremely reactive nature of $\mathrm{Li}_{2} \mathrm{O}$ at high temperatures with crucible materials, introduction of impurities (metallic or $\mathrm{LiOH}$ ) or just estimations on the part of the authors. Recently, several investigators $(4-6)$ have proposed melting points for $L_{1}{ }_{2} 0$ ranging from $1430^{\circ}$ to $1438^{\circ} \mathrm{C}$, which are close to the $1427^{\circ} \mathrm{C}$ proposed by Brewer and Margrave ${ }^{(3)}$. For this study, the figure $1432 \pm 6^{\circ} \mathrm{C}$ has been adopted as an average value derived from the latest investigators. The melting points for some of the solid breeder materials have been listed in Figure 4.2.1.

\subsection{VAPORIZATION}

\subsubsection{Li $\mathrm{i}_{2} \mathrm{O}$}

Ikeda et a1. (8) has obtained the vapor pressure of $\mathrm{Li}_{2} \mathrm{O}$ by high temperature mass spectrometry using a Pt Knudsen cell. The Li partial pressure, i.7ustrated in Figure 4.3.1.1, was in fairly good agreement with the findings of. Kudo et a $1:$ (9) over the same temperature regime. Their results have been 
Figure 4.2.1 Melting Points of Solid Breeder Candidates

\begin{tabular}{|c|c|c|}
\hline MATERIAL & M.P. (OC) & COMMENTS \\
\hline $\mathrm{Li}_{2} \mathrm{O}$ & $1432 \pm 6$ & $\begin{array}{l}\text { Avg. of values reported } \\
(1427,1430,1432,1438)\end{array}$ \\
\hline $\mathrm{B}-\mathrm{Li}{ }_{5} \mathrm{AlO}_{4}$ & 1047 & Decomposes/Triple Point \\
\hline$\gamma-\mathrm{LiA10} 2$ & 1610 & \\
\hline $\mathrm{LiAl}_{5} \mathrm{O}_{8}$ & 1950 & \\
\hline $\mathrm{Li}_{4} \mathrm{SiO}_{4}$ & 1255 & Decomposes \\
\hline $\mathrm{Li}_{2} \mathrm{SiO}_{3}$ & 1201 & \\
\hline $\mathrm{Li}_{2} \mathrm{Si}_{2} \mathrm{O}_{5}$ & 1033 & \\
\hline $\mathrm{Li}_{4} \mathrm{TiO}_{4}$ & 1200 & Decomposes \\
\hline $\mathrm{Li}_{2} \mathrm{TiO}_{3}$ & 1535 & \\
\hline $\mathrm{Li}_{8} \mathrm{ZrO}_{6}$ & 1295 & \\
\hline $\mathrm{Li}_{4} \mathrm{ZrO}_{4}$ & Unknown & \\
\hline $\mathrm{Li}_{2} \mathrm{ZrO}_{3}$ & 1600 & \\
\hline
\end{tabular}

1isted below with $\mathrm{P}_{\mathrm{L} i}$ being given in Pascals:

Ikeda et a1. (8) $T=1316$ to $1603 \mathrm{~K}$

$$
\begin{aligned}
\log P_{L i} & =-\left(19.02 \times 10^{3} / \mathrm{T}\right)+12.22 \\
\text { Kudo et al. (9) } \mathrm{T} & =1352 \text { to } 1663 \mathrm{~K} \\
\log \mathrm{P}_{\mathrm{Li}} & =-\left(18.19 \times 10^{3} / \mathrm{T}\right)+12.09
\end{aligned}
$$

In addition, Ikeda et a1. (8) reported partial pressures for $\mathrm{O}_{2}$ and $\mathrm{Li}_{2} \mathrm{O}$ while Kudo et a1. (9) detected pressures for $\mathrm{Li} 2, \mathrm{LiO}, \mathrm{Li}_{2} \mathrm{O}, \mathrm{Li}_{3} \mathrm{O}$, and $\mathrm{Li}_{2} \mathrm{O}_{2}$ over the $\mathrm{Li}_{2} \mathrm{O}$ samples. Some of their results have been plotted in Figure 4.3.1.2 according to the following equations:

$$
\begin{aligned}
\log P_{0_{2}}(\mathrm{~Pa}) & =-\left(17.80 \times 10^{3} / \mathrm{T}\right)+10.62 \\
\text { where } T & =1316 \text { to } 1603(\mathrm{~K}) \\
\log \mathrm{P}_{\mathrm{Li0}}(\mathrm{Pa}) & =-\left(19.85 \times 10^{3} / \mathrm{T}\right)+11.21 \\
\text { where } T & =1352 \text { to } 1663(\mathrm{~K}) \\
\log \mathrm{P}_{\mathrm{Li}_{2} \mathrm{O}}(\mathrm{Pa}) & =-\left(20.60 \times 10^{3} / \mathrm{T}\right)+13.40 \\
\text { where } T & =1352 \text { to } 1663(\mathrm{~K})
\end{aligned}
$$

Several other investigators ${ }^{(10-13)}$ have determined the partial pressure of $\mathrm{Li}_{2} \mathrm{O}$ over $\mathrm{Li}_{2} \mathrm{O}$ in a Pt cell, Figure 4.3.1.3, and are in good agreement except 


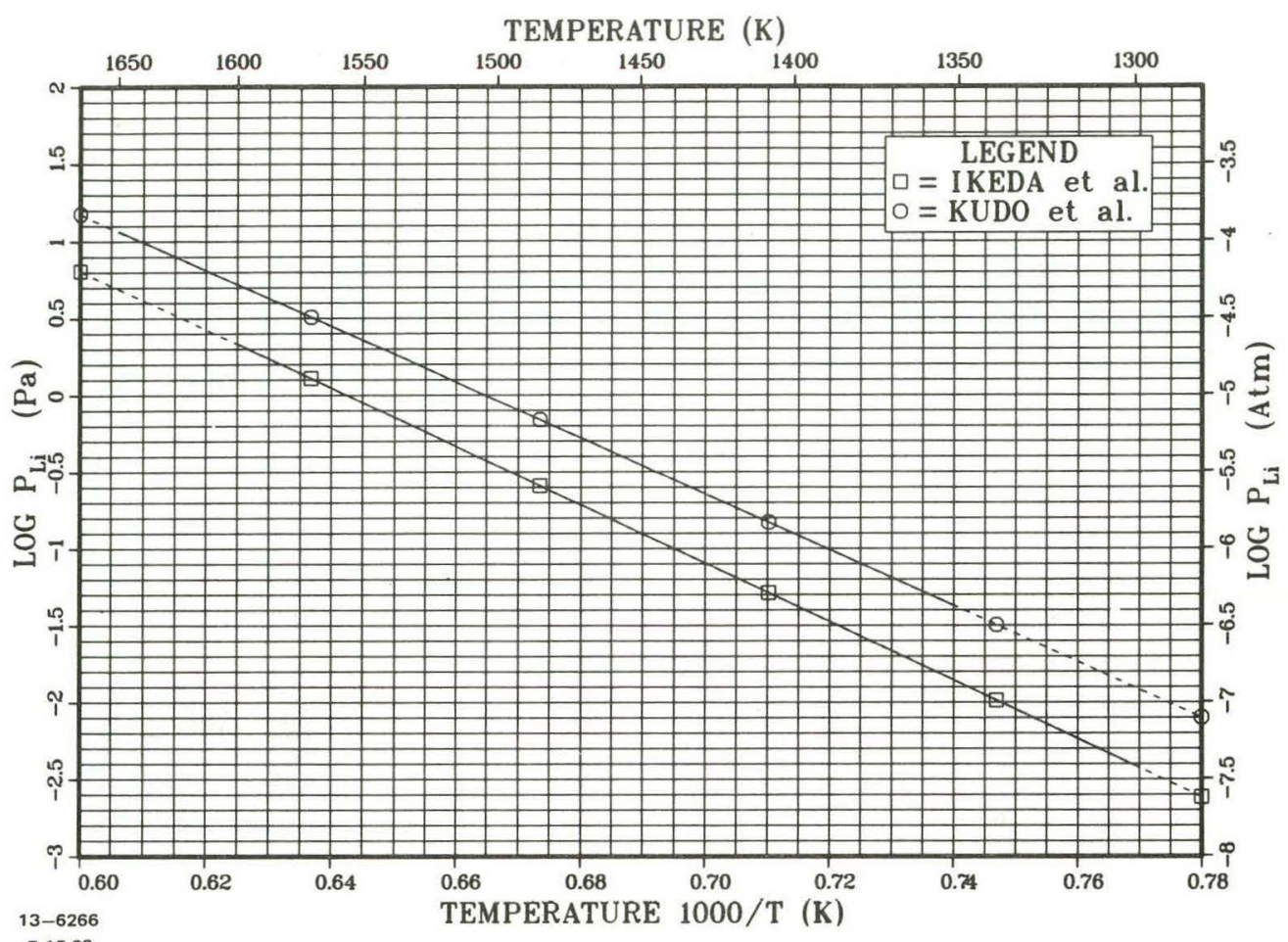

Figure 4.3.1.1 Li Partial Pressure over $\mathrm{Li}_{2} \mathrm{O}$ in a Pt Knudsen Cell

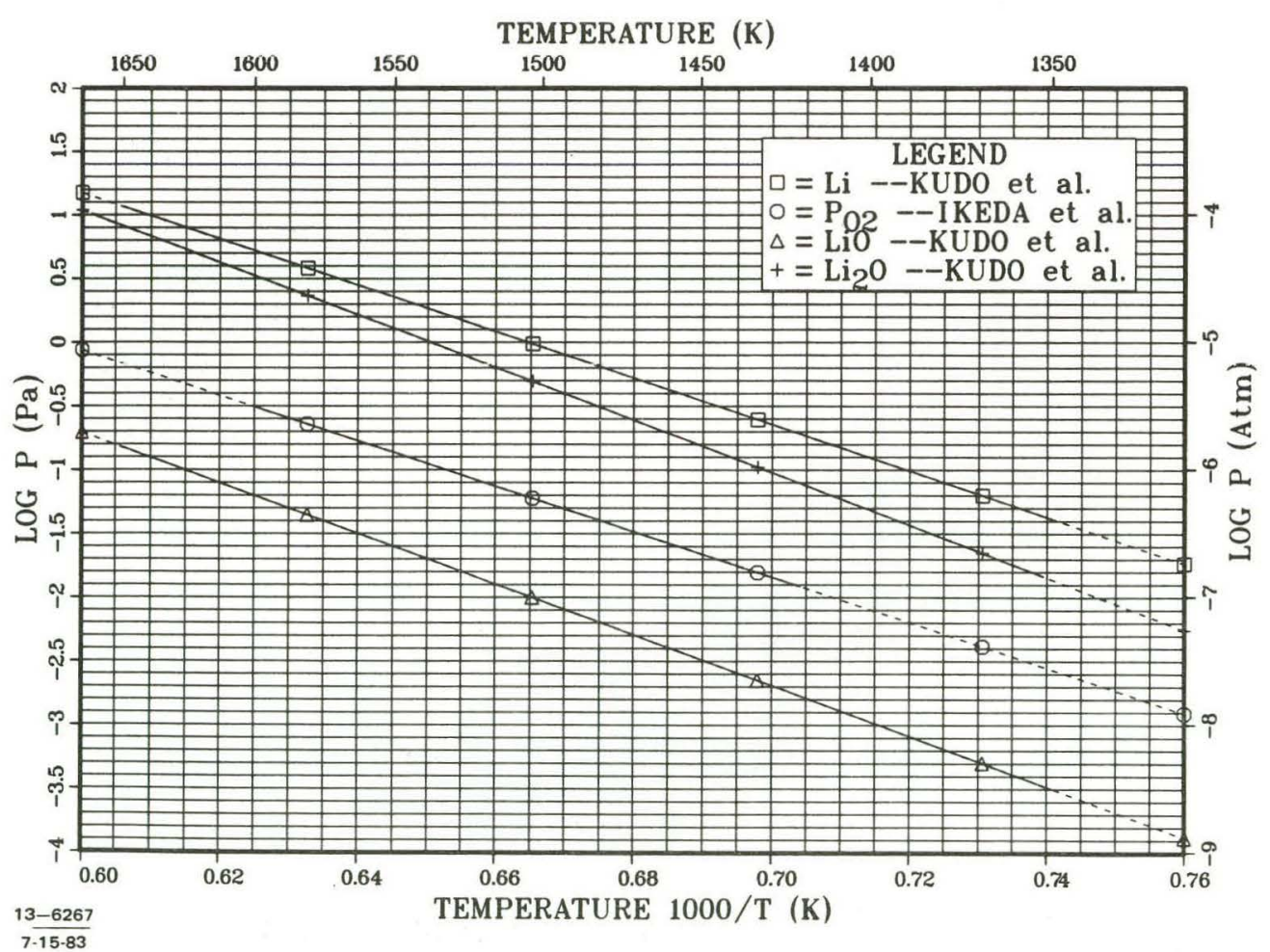

Figure 4.3.1.2 Various Partial Pressures over $\mathrm{Li}_{2} \mathrm{O}$ in a Pt Knudsen Cell 


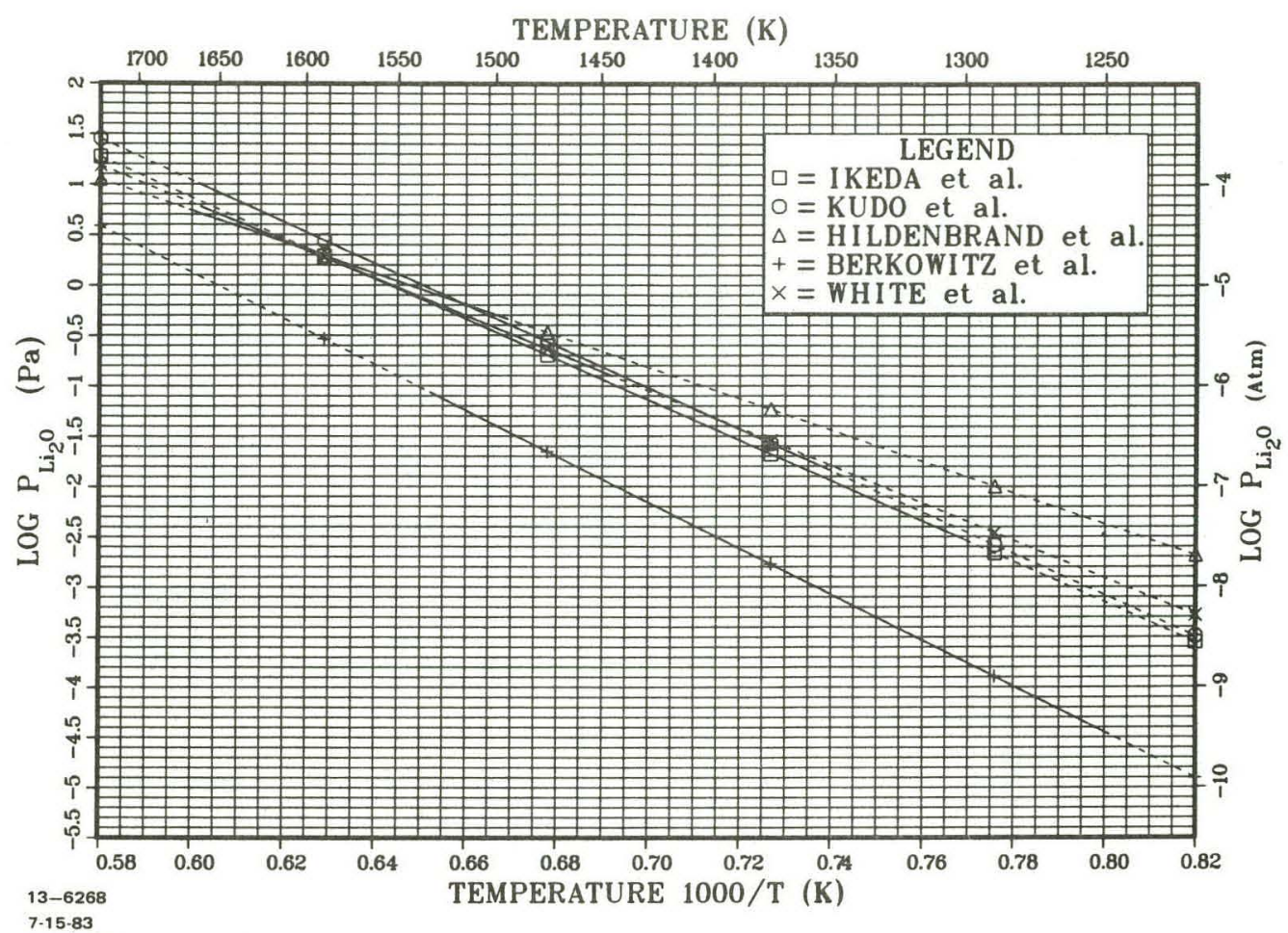

Figure 4.3.1.3 Li2O Partial Pressure over Li2O in a Pt Knudsen Cell

for Berkowitz et al. (11) who differed from the neutral conditions with the appearance of $\mathrm{H}_{2} \mathrm{O}$ species. Arons et al. (13) also made some preliminary measurements using controlled quantities of $\mathrm{H}_{2} \mathrm{O}$ in the carrier gas stream and found results similar to that of Berkowitz et a1.(11). They have shown that moisture enhances the volatility of $\mathrm{Li}_{2} \mathrm{O}$ within the system.

In addition to vaporization data obtained using Pt cells, Ikeda et.al. measured the pressures obtained using $\mathrm{Ni}, \mathrm{Nb}, \mathrm{Ta}$, and Mo cells with the subsequent results:

$$
\begin{aligned}
& \text { for } \mathrm{Ni} \text {-cell and } \mathrm{T}=1350-1500 \mathrm{~K} \\
& \log P_{L i}(\mathrm{~Pa})=-\left(17.48 \times 10^{3} / \mathrm{T}\right)+11.65 \\
& \text { for } \mathrm{Nb} \text {-cel1 and } \mathrm{T}=1250-1375 \mathrm{~K} \\
& \log P_{L_{i}}(P a)=-\left(22.32 \times 10^{3} / T\right)+16.64 \\
& \text { for } \mathrm{Ta} \text {-cell and } \mathrm{T}=1230-1450 \mathrm{~K} \\
& \log P_{L i}(P a)=-\left(19.26 \times 10^{3} / T\right)+13.43 \\
& \text { for Mo-cell and } T=1250-1375 \mathrm{~K} \\
& \log P_{L i}(P a)=-\left(19.94 \times 10^{3} / T\right)+14.82
\end{aligned}
$$


The results, shown in Figure 4.3.1.4, indicate that $\mathrm{Ni}$ and $\mathrm{Ta}$ are least reactive over the temperature range of the study. The Mo and $\mathrm{Nb}$ cells achieved higher $\mathrm{P}_{\mathrm{Li}}$ at lower temperatures indicative of the amount of strong interaction between the cell and the $\mathrm{Li}_{2} \mathrm{O}$ sample. As in most previous experiments, neutral conditions existed with no $\mathrm{H}_{2} \mathrm{O}$ species being observed.

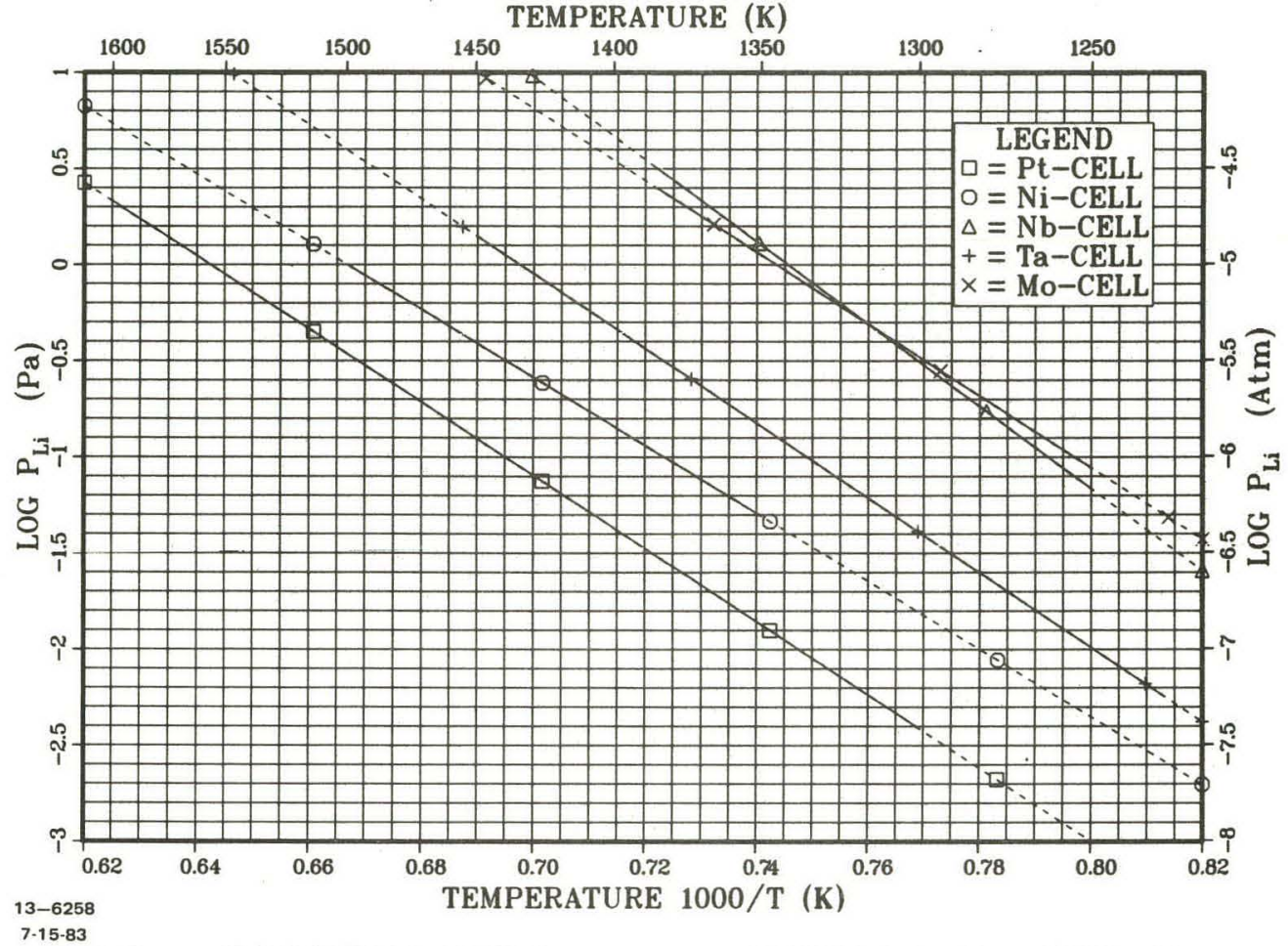

Figure 4.3.1.4 Li Partial Pressure over Li2O in Knudsen Cells of Various Metals

\subsection{2 $\underline{\mathrm{Li}_{2} \mathrm{O}-\mathrm{Al}_{2} \mathrm{O}_{3} \text { SYSTEM }}$}

\subsubsection{1 $\quad \mathrm{B}-\mathrm{Li}_{5} \mathrm{AlO}_{4}$}

Ikeda et al. (14) and Guggi et al. (15) measured the Li partial pressure over B- and molten $\mathrm{Li}_{5} \mathrm{AlO}_{4}$ using a Pt Knudsen cell with slightly differing results, as seen in Figure 4.3.2.1. Ikeda et al. (14) found for $\mathrm{B}-\mathrm{Li}_{5} \mathrm{AlO}_{4}$ (solid) and $\mathrm{T}=1262-1333 \mathrm{~K}$,

$$
\log P_{L i}(P a)=-(18.64 \times 103 / T)+11.19
$$

while Guggi et al. (15) suggested the relationship for $\mathrm{B}-\mathrm{Li}_{5} \mathrm{AlO}_{4}$ (solid) and $\mathrm{T}=1195-1362 \mathrm{~K}$,

$$
\log P_{L_{i}}(P a)=-\left(17.23 \times 10^{3} / T\right)+10.80
$$




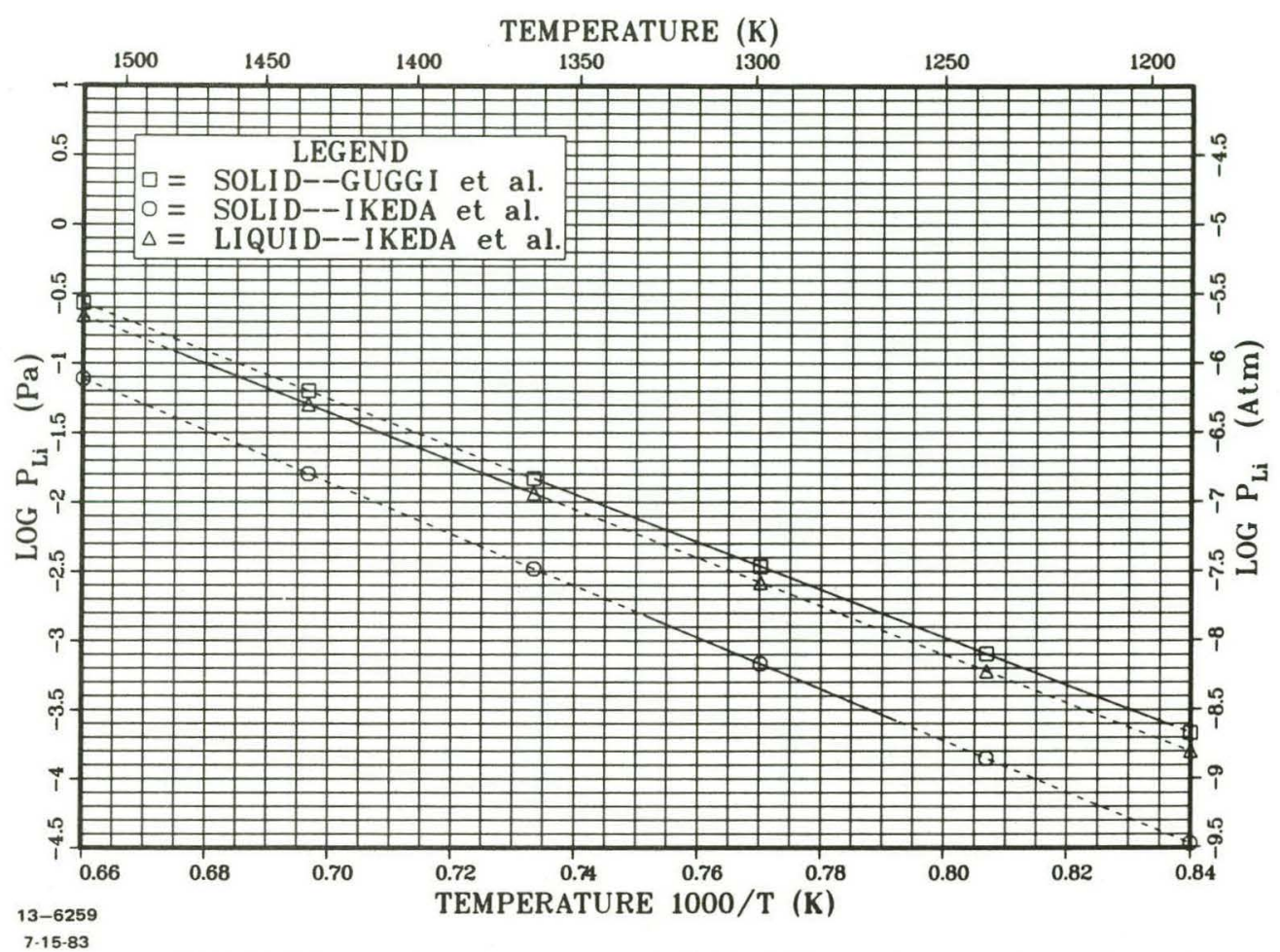

Figure 4.3.2.1 Li Partial Pressure over $\beta-\mathrm{Li5AlO}_{4}$ (s,l)in a Pt Knudsen Cell

No explanation was apparent to account for the differences between the results since the investigators took elaborate steps to insure sample purity and homogeneity, and measurement reproducibility.

\subsubsection{2 $\gamma-\mathrm{LiAlO}_{2}$}

The results of Ikeda et al. (14) for the vaporization pressures over solid $\gamma-\mathrm{LiAlO}_{2}$ from a Pt Knudsen cell are shown in Figure 4.3.2.2 and given below:

for $T=1480-1723 \mathrm{~K}$ (not shown on Figure 4.3.2.2)

$$
\log P_{L i}(P a)=-\left(20.23 \times 10^{3} / T\right)+11.17
$$

for $T=1723-1923 \mathrm{~K}$

$$
\begin{aligned}
& \log P_{L i}(\mathrm{~Pa})=-\left(21.45 \times 10^{3} / \mathrm{T}\right)+11.86 \\
& \log \mathrm{P}_{\mathrm{O}_{2}}(\mathrm{~Pa})=-\left(20.69 \times 10^{3} / \mathrm{T}\right)+10.39
\end{aligned}
$$

for $T=1850-1923(\mathrm{~K})$

$$
\log \mathrm{PLi}_{2} \mathrm{O}(\mathrm{Pa})=-\left(23.58 \times 10^{3} / \mathrm{T}\right)+10.56
$$

for $\mathrm{T}=1640-1923(\mathrm{~K})$

$\log P_{\text {LiO }}(\mathrm{Pa})=-\left(22.04 \times 10^{3} / \mathrm{T}\right)+9.78$ 


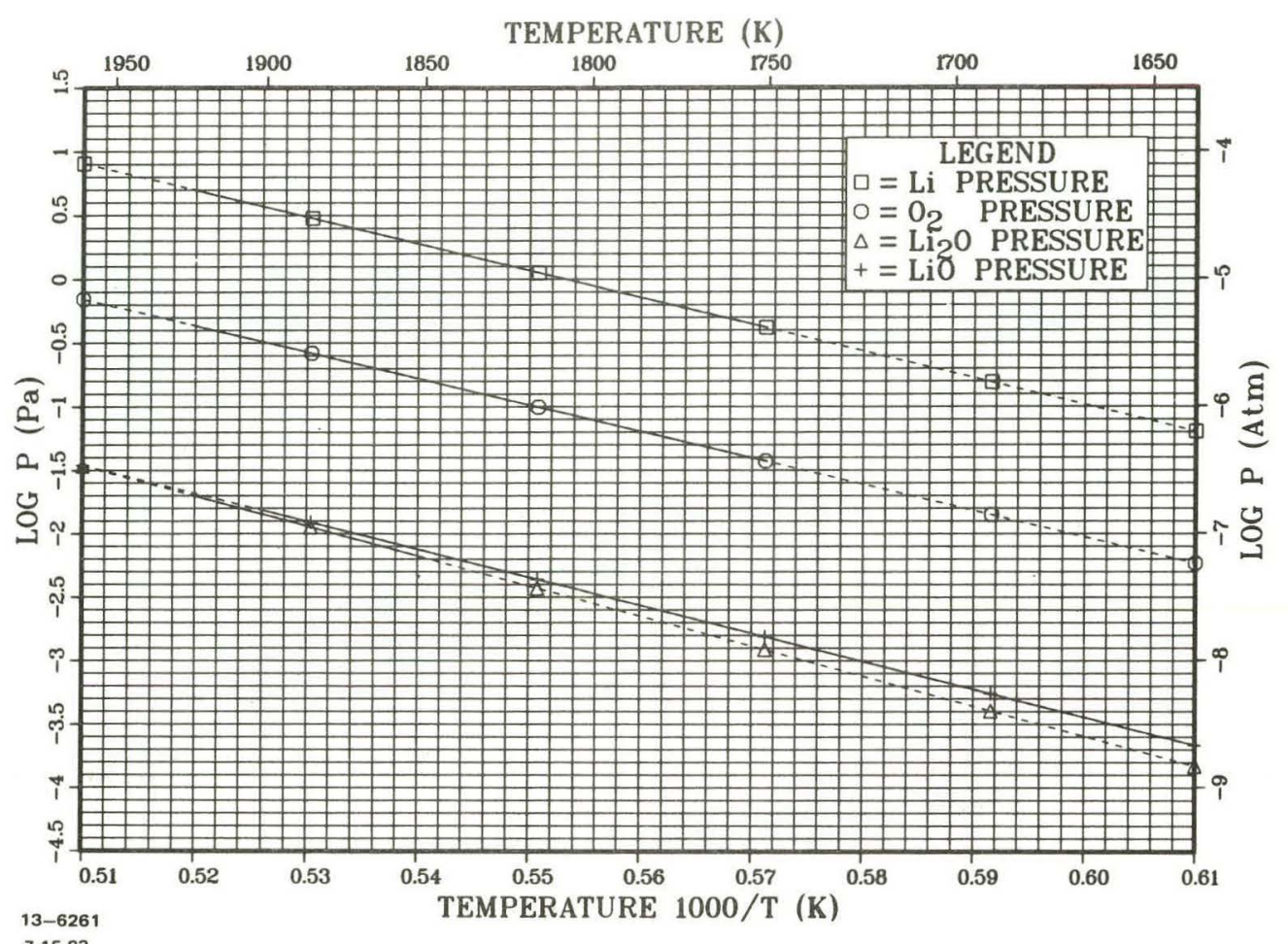

Figure 4.3.2.2 Various Partial Pressures over $\gamma \cdot \mathrm{LiAlO}_{2}$ in a Pt Knudsen Cell

The data for $\mathrm{P}_{\mathrm{Li}}$ presented are in good agreement with those of Guggi et al. (15) and at higher temperatures, with those of Hildenbrand ${ }^{(16)}$, but are smaller than those of Popkov and Semonov (17) as illustrated in Figure 4.3.2.3.

Guggi et a1. (18) examined the vaporization of $\gamma-\mathrm{LiAlO}_{2}$ in Mo and Ta effusion cells in addition to the standard Pt cell. Their results are plotted in Figure 4.3.2.4 and reveal very little difference between using Mo or $\mathrm{Ta}$ in contact with $\gamma-\mathrm{LiAlO}_{2}$. This was in contrast to the noticeable difference found when $\mathrm{Li}_{2} \mathrm{O}$ was used (see Figure 4.3.1.4). There, Ta resulted in much less $\mathrm{Li}$ vaporization than Mo over similar temperatures. As expected, $\gamma-\mathrm{LiAlO}_{2}$ in a $\mathrm{Pt}$ cell resulted in lower $\mathrm{P}_{\mathrm{Li}}$. The results are:

$$
\begin{aligned}
& \text { for Mo cell and } T=1250-1430 \mathrm{~K} \\
& \qquad \log P_{L_{i}}(\mathrm{~Pa})=-\left(20.37 \times 10^{3} / \mathrm{T}\right)+12.75 \\
& \text { for Ta cell and } T=1330-1480 \mathrm{~K} \\
& \quad \log P_{L i}(\mathrm{~Pa})=-\left(17.02 \times 10^{3} / \mathrm{T}\right)+10.35 .
\end{aligned}
$$


TEMPERATURE $(\mathrm{K})$

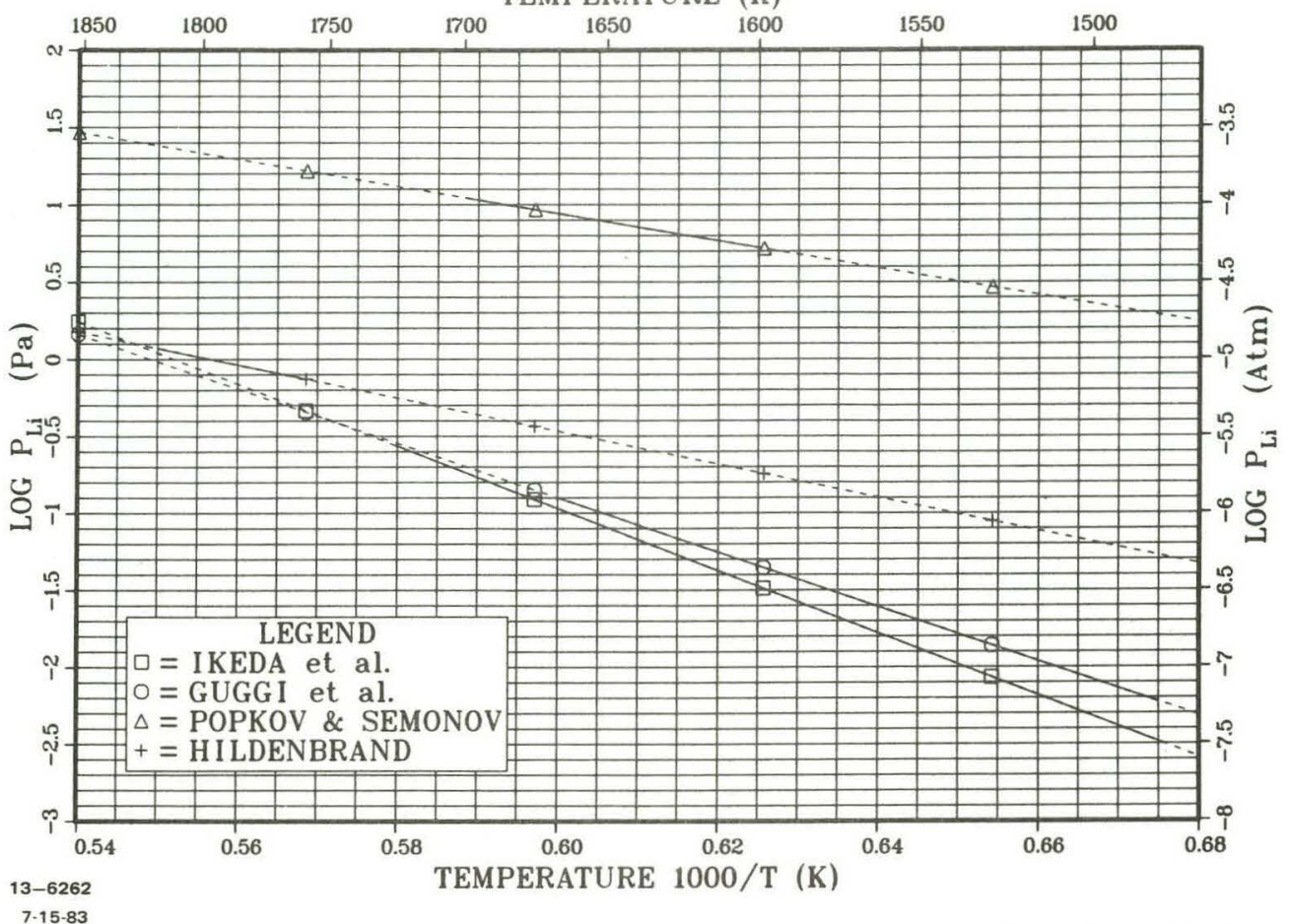

Figure 4.3.2.3 Li Partial Pressures over $\gamma \cdot \mathrm{LiAlO}_{2}$ in a $\mathrm{Pt}$ Knudsen Cell

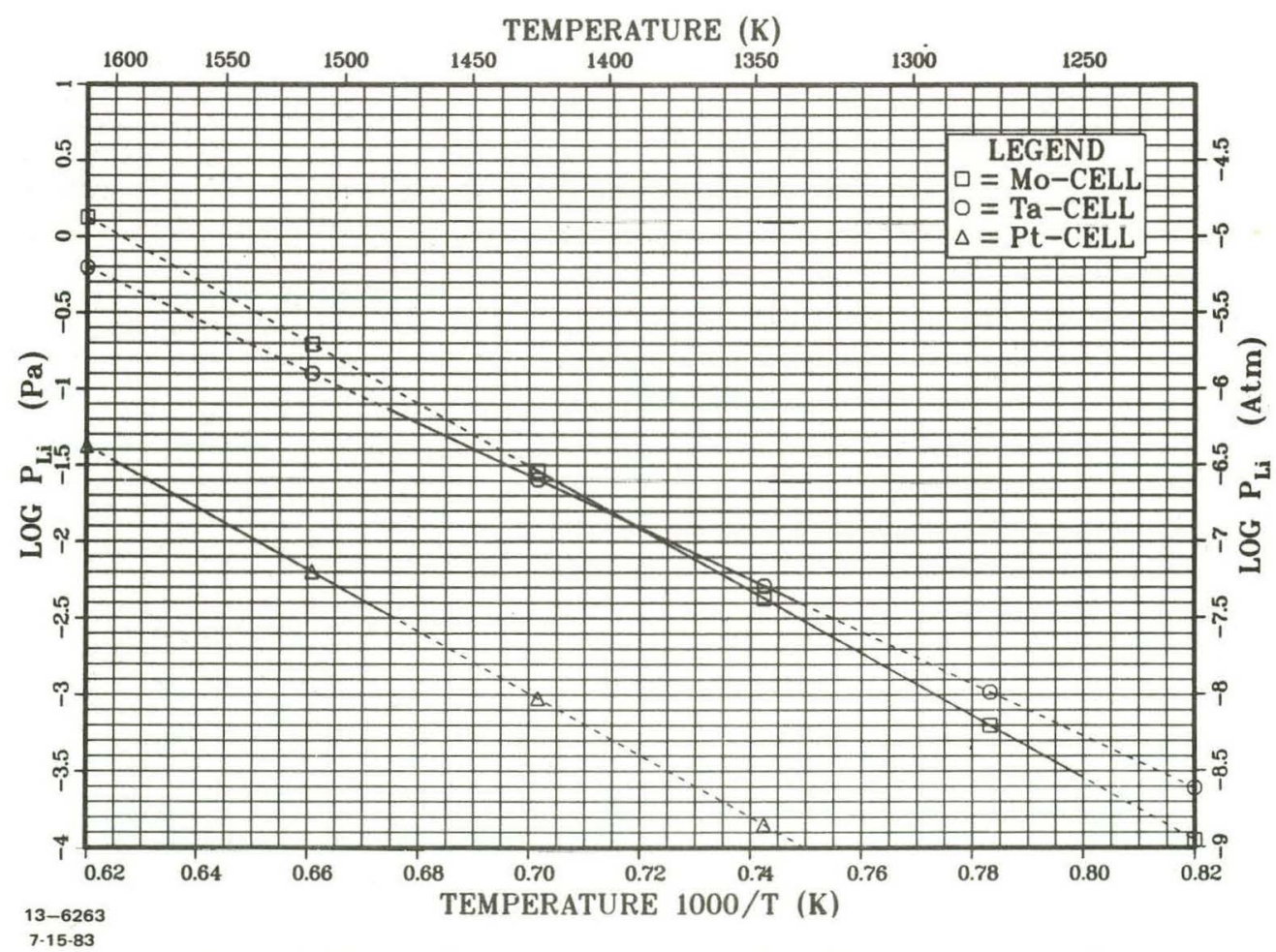

Figure 4.3.2.4 Li Partial Pressures over $\gamma \cdot \mathrm{LiAlO}_{2}$ in Knudsen Cells of Various Metals 


\subsubsection{3 $\mathrm{LiAl}_{5} \mathrm{O}_{8}$}

Ikeda et al. (14) measured the partial pressures of $\mathrm{Li}$ and LiO over LiA1508 and found $P_{L i}$ to be slightly higher than an extrapolation of data by Guggi et al. (15). Their results are plotted in Figure 4.3 .2 .5 and given below:

$$
\begin{aligned}
& \text { for } T=1493-1770 \mathrm{~K} \\
& \quad \log P_{L i}(\mathrm{~Pa})=-\left(21.17 \times 10^{3} / \mathrm{T}\right)+11.49 \\
& \text { for } T=1330-1570(\mathrm{~K}) \quad \text { (Guggi et a1.) } \\
& \quad \log P_{\mathrm{Li}}(\mathrm{Pa})=-\left(9.92 \times 10^{3} / \mathrm{T}\right)+4.19 \\
& \text { for } T=1580-1750(\mathrm{~K}) \\
& \quad \log P_{\mathrm{Li} 0}(\mathrm{~Pa})=\left(25.32 \times 10^{3} / \mathrm{T}\right)+11.20
\end{aligned}
$$

\subsection{3 $\underline{\mathrm{Li}_{2} \mathrm{O}-\mathrm{SiO}_{2}}$}

\subsubsection{1 $\mathrm{Li}_{4} \mathrm{SiO}_{4}$}

No data was found.

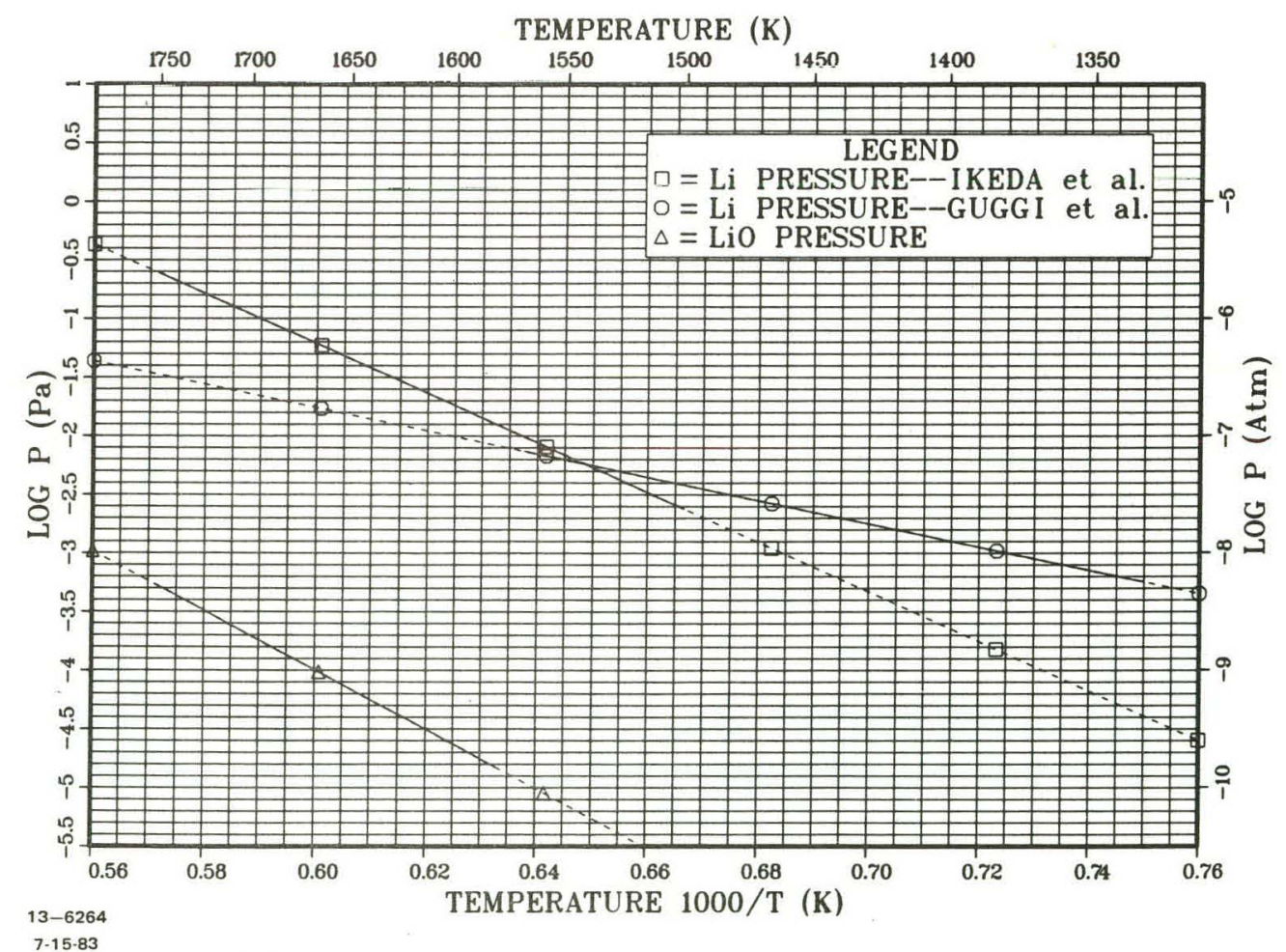

Figure 4.3.2.5 Partial Pressures over LiAl50 8 in a Pt Knudsen Cell 


\subsubsection{2 $\mathrm{Li}_{2} \mathrm{SiO}_{3}$}

Nakagawa et a1. (19) have studied the vaporization of $\mathrm{Li}_{2} \mathrm{SiO}_{3}$ (s/1) using a Pt Knudsen cell over a temperature range of 1166-1762 K. The determined partial pressures of $\mathrm{Li}(\mathrm{g}), \mathrm{LiO}(\mathrm{g})$, and $\mathrm{Li}_{2} \mathrm{O}(\mathrm{g})$ over $\mathrm{Li}_{2} \mathrm{SiO}_{3}(\mathrm{~s} / 1)$ are 1 isted below and depicted in Figure 4.3.3.1:

$$
\begin{array}{r}
\text { for } \mathrm{Li}_{2} \mathrm{SiO}_{3}-\text { solid and } \mathrm{T}=1166-1461(\mathrm{~K}) \\
\log \mathrm{P}_{\mathrm{Li}}(\mathrm{Pa})=-\left(16.98 \times 10^{3} / \mathrm{T}\right)+9.63 \\
\text { for } \mathrm{Li}_{2} \mathrm{SiO}_{3}-1 \text { iquid and } \mathrm{T}=1479-1762(\mathrm{~K}) \\
\log \mathrm{P}_{\mathrm{Li}}(\mathrm{Pa})=-\left(16.04 \times 10^{3} / \mathrm{T}\right)+9.10 \\
\mathrm{~T}=1601-1762(\mathrm{~K}) \\
\log \mathrm{PLiO}_{\mathrm{La}}(\mathrm{Pa})=-\left(23.22 \times 10^{3} / \mathrm{T}\right)+10.06 \\
\mathrm{~T}=1527-1762(\mathrm{~K}) \\
\log \mathrm{P}_{\mathrm{Li}} \mathrm{O}(\mathrm{Pa})=-\left(17.49 \times 10^{3} / \mathrm{T}\right)+6.99
\end{array}
$$

Other partial pressures of $\mathrm{SiO}$ and $\mathrm{Li}_{2} \mathrm{SiO}_{3}$ were seen between 1527 and $1762 \mathrm{~K}$ but they were less than LiO and not depicted in Figure 4.3.3.1.

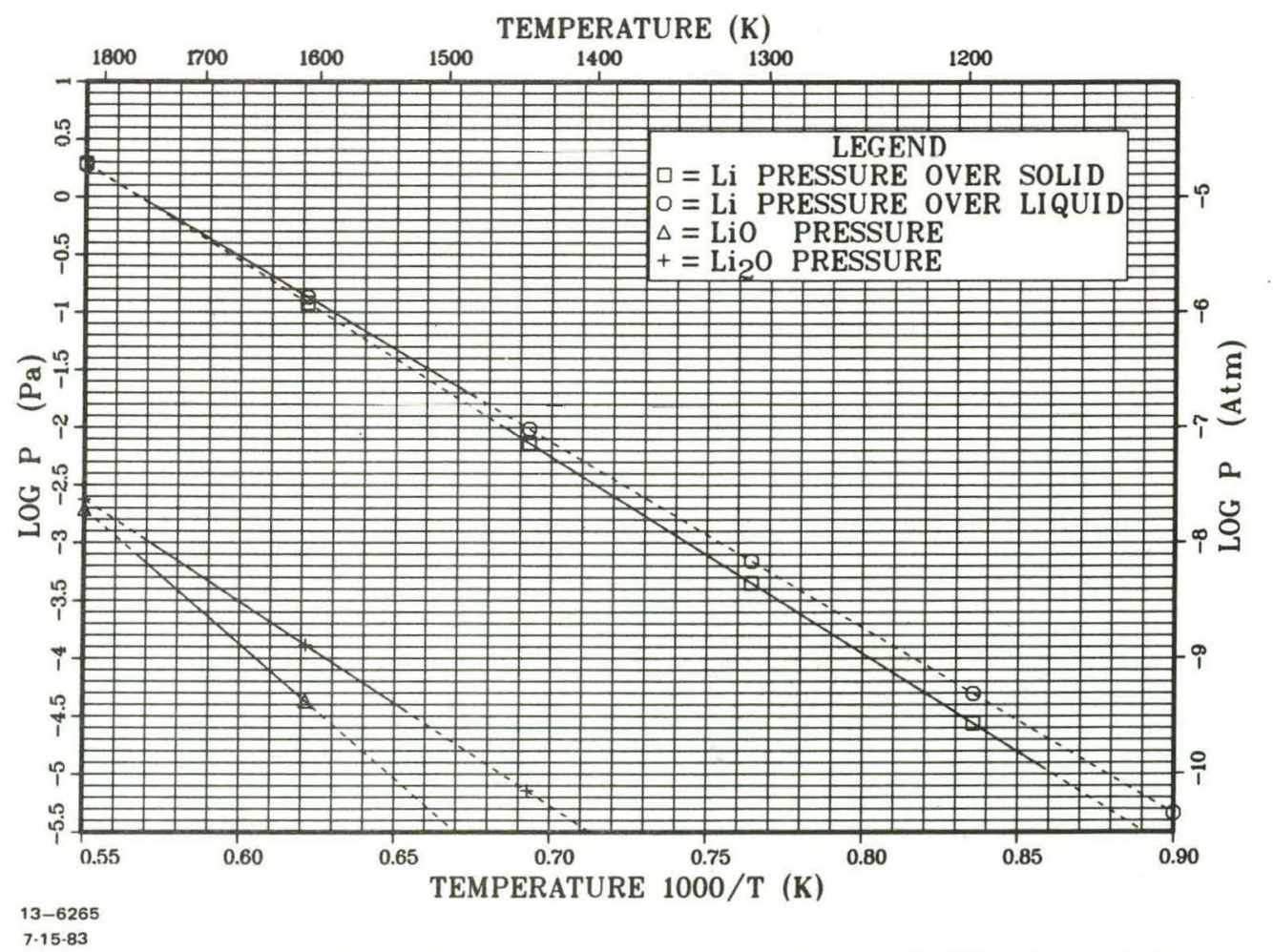

Figure 4.3.3.1 Partial Pressures over Li2SiO3 in a Pt Knudsen Cell 


\subsection{4 $\mathrm{Li}_{2} \mathrm{O}-\mathrm{TiO}_{2}$}

No data have been found regarding the vaporization pressures of $\mathrm{Li}_{4} \mathrm{TiO}_{4}$ or $\mathrm{Li}_{2} \mathrm{TiO}_{3}$.

\subsection{5 $\mathrm{Li}_{2} \mathrm{O}-\mathrm{ZrO}_{2}$}

\subsubsection{1 $\mathrm{Li}_{8} \mathrm{ZrO}_{6}$}

Neubert and Guggi ${ }^{(20)}$ calculated the pressure of $\mathrm{Li}$ above $\mathrm{Li}_{8} \mathrm{ZrO}_{6}$ using a Pt Knudsen cell and calculated a relationship for $T=1302-1604$ (K):

$$
\log P_{L i}(\mathrm{~Pa})=-\left(17.94 \times 10^{3} / \mathrm{T}\right)+11.07
$$

They stated that the vapor phase above the $\mathrm{Li}_{8} \mathrm{ZrO}_{6}$ consisted mainly of Li and $\mathrm{O}_{2}$ with the vapor pressure of $\mathrm{Li}_{2} \mathrm{O}$ amounting to $\approx 10 \%$ of $\mathrm{Li} . \mathrm{Li}, \mathrm{Li}_{2}$ and 0 were species "seen" in very small quantities. Their results have been displayed in Figure 4.3.5.1.

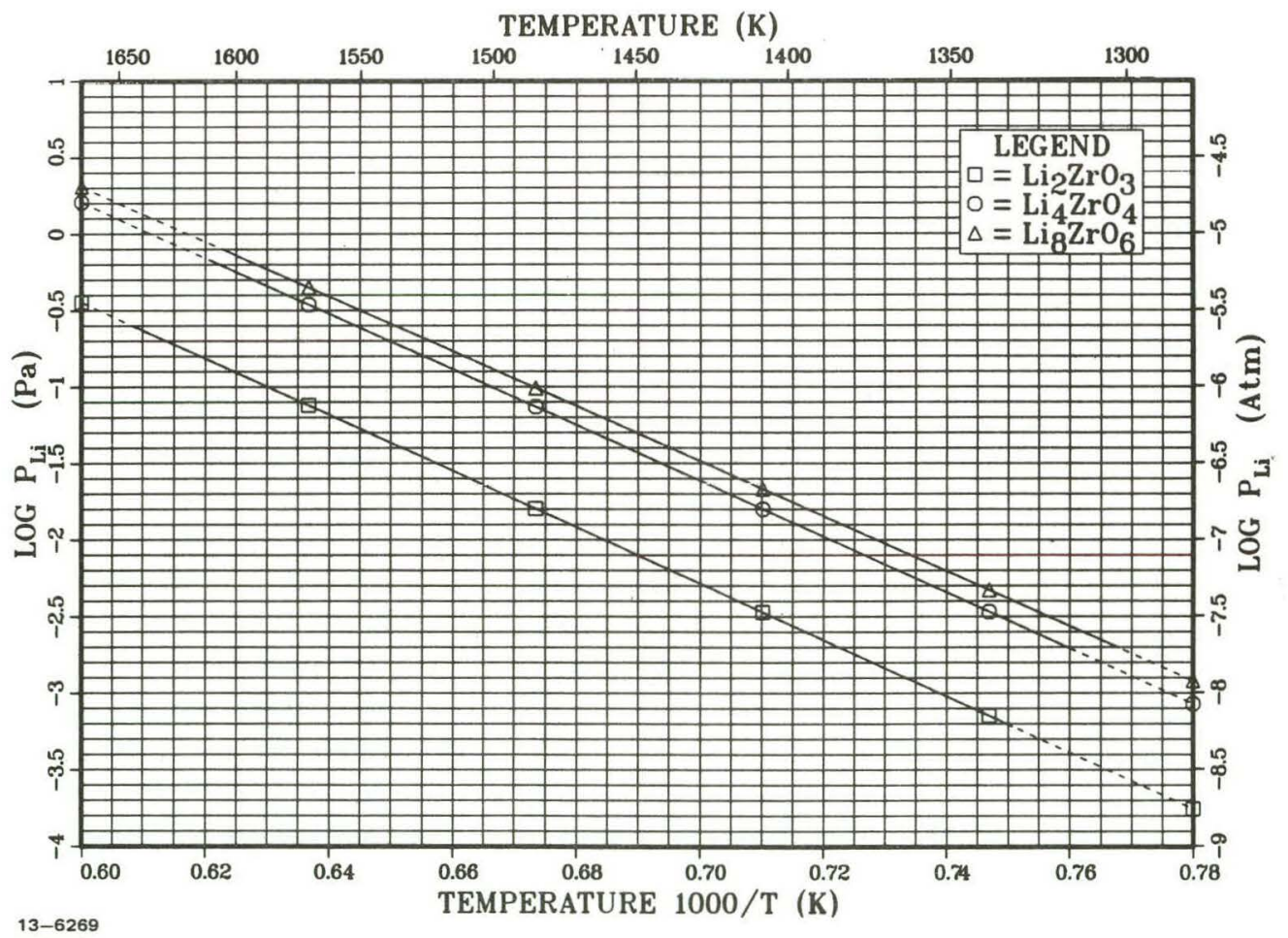

Figure 4.3.5.1 Li Partial Pressures over the $\mathrm{Li}_{2} \mathrm{O}-\mathrm{ZrO}_{2}$ System in $\mathrm{Pt}$ Knudsen Cells 


\subsubsection{2 $\mathrm{Li}_{4} \mathrm{ZrO}_{4}$}

Neubert and Guggi ${ }^{(20)}$ measured the vapor pressure of $\mathrm{Li}$ above $\mathrm{Li}_{4} \mathrm{ZrO}_{4}$ and calculated the least-squares relationship below for $T=1316-1611(\mathrm{~K})$ :

$$
\log P_{\mathrm{Li}}(\mathrm{Pa})=-\left(18.21 \times 10^{3} / \mathrm{T}\right)+11.13
$$

As with the $\mathrm{Li}_{8} \mathrm{ZrO}_{6}$, they noticed small amounts of $\mathrm{Li}_{2} \mathrm{O}, \mathrm{LiO}, \mathrm{Li}_{2}$ and 0 but no quantities were reported. The results have been included in Figure 4.3.5.1.

\subsubsection{3 $\mathrm{Li}_{2} \mathrm{ZrO}_{3}$}

Neubert and Guggi ${ }^{(20)}$ measured the vapor pressure of $\mathrm{Li}$ above solid $\mathrm{Li}_{2} \mathrm{ZrO}_{3}$ and saw the relationship for $T=1332-1642(\mathrm{~K})$ :

$$
\log P_{L i}(P a)=-\left(18.39 \times 10^{3} / T\right)+10.59
$$

Figure 4.3.5.1 contains the data and, as expected, the $\mathrm{Li}_{2} \mathrm{ZrO}_{3}$ sample resulted in less volatility when compared to $\mathrm{Li}_{8} \mathrm{ZrO}_{6}$ and $\mathrm{Li}_{4} \mathrm{ZrO}_{4}$ for a $\mathrm{Pt}$ cell.

\subsubsection{Li, 20 - METAL OXIDE SYSTEMS}

A comparison of the $\mathrm{P}_{\mathrm{Li}}$ exerted in a $\mathrm{Pt}$ cell among the solid breeder materials $\left(\mathrm{Li}_{2} \mathrm{O}, \mathrm{Li}_{8} \mathrm{ZrO}_{6}, \mathrm{~B}-\mathrm{Li}_{5} \mathrm{AlO}_{4}, \mathrm{Li}_{2} \mathrm{SiO}_{3}, \mathrm{Li}_{2} \mathrm{ZrO}_{3}\right.$ and $\left.\gamma-\mathrm{LiAlO} \mathrm{O}_{2}\right)$ has been made in Figure 4.3.6.1. $\mathrm{Li}_{2} \mathrm{O}$ has the highest values, as expected, followed by $\mathrm{Li}_{8} \mathrm{ZrO}_{6}$ and $\beta-\mathrm{Li}_{5} \mathrm{AlO}_{4}$ and then, $\gamma-\mathrm{LiAlO}{ }_{2}$, with the lowest Li atom density, has the lowest $\mathrm{P}_{\mathrm{Li}}$ measured.

In compatibility experiments featuring $\mathrm{Li}_{2} \mathrm{O}$ pellets in contact with Mo alloys or with $\mathrm{Fe}-\mathrm{Ni}-\mathrm{Cr}$ alloys, certain corrosion products have appeared, namely $\mathrm{Li}_{4} \mathrm{MoO}_{5}, \mathrm{Li}_{5} \mathrm{FeO}_{4}$ and $\mathrm{LiCrO}_{2}$. These compounds and their vaporization trends have been studied by several investigators $(21-23)$, and their findings are displayed in Figure 4.3.6.2. Ikeda et al. ${ }^{(21)}$ obtained vaporization data on both liquid $\mathrm{Li}_{2} \mathrm{MoO}_{4}$ and $\beta-\mathrm{Li}_{4} \mathrm{MoO}_{5}$ with a Pt Knudsen cell. The results were:

$$
\begin{aligned}
& \text { Liquid } \mathrm{Li}_{2} \mathrm{MoO}_{4} \text { for } \mathrm{T}=1160-1400(\mathrm{~K}) \\
& \quad \log \mathrm{P}_{\mathrm{Li}}(\mathrm{Pa})=-\left(17.71 \times 10^{3} / \mathrm{T}\right)+10.18 \\
& \beta-\mathrm{Li}_{5} \mathrm{MoO}_{4} \text { for } \mathrm{T}=1150-1445(\mathrm{~K}) \\
& \quad \log \mathrm{P}_{\mathrm{Li}}(\mathrm{Pa})=-\left(18.70 \times 10^{3} / \mathrm{T}\right)+11.04
\end{aligned}
$$



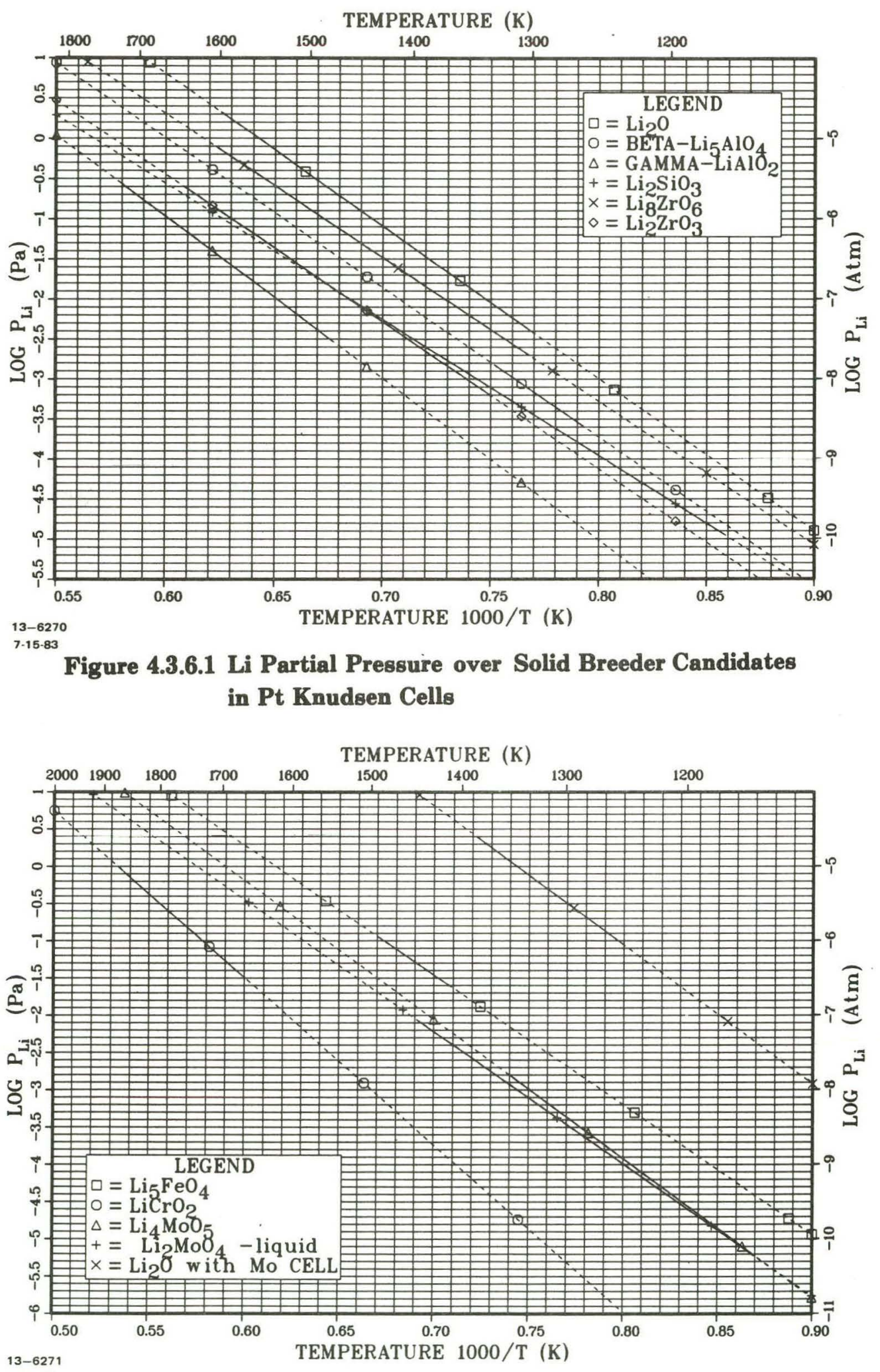

Figure 4.3.6.2 Li Partial Pressure Over Corrosion Products Found During Li2O/Metal Compatibility Experiments (Measurements were made in a $\mathrm{Pt}$ Knudsen Cell) 
Much less lithium vaporization was noticed with $\mathrm{Li}_{2} \mathrm{MOO}_{4}$ and $\mathrm{B}-\mathrm{Li}_{5} \mathrm{MoO}_{4}$ as compared to $\mathrm{Li}_{2} \mathrm{O}$ in contact with a Mo knudsen cell. Thus, even though $\mathrm{Li}_{2} \mathrm{MoO}_{4}$ and $\mathrm{B}-\mathrm{Li}_{5} \mathrm{MOO}_{4}$ have only been found as corrosion products of $\mathrm{Li}_{2} \mathrm{O}$ in contact with Mo or a Mo alloy, they are not the total contribution to the $P_{L i}$ in the temperature region.

$\mathrm{Li}_{5} \mathrm{FeO}_{4}$ and $\mathrm{LiCrO}_{2}$ have been the two primary corrosion products found in Li20/Fe-Ni-Cr alloy compatibility couples. Takeshita et al. (22) examined the vaporization of $\mathrm{Li}_{5} \mathrm{FeO}_{4}$ with a $\mathrm{Pt}$ Knudsen cell and calculated the relationship:

$$
\begin{aligned}
& \text { for } T=1410-1490(K) \\
& \quad \log P_{L i}(P a)=-\left(17.40 \times 10^{3} / T\right)+10.72
\end{aligned}
$$

$\mathrm{Li}$ and $\mathrm{O}_{2}$ were the predominant species observed along with a small quantity of $\mathrm{LiO}$ and $\mathrm{Li}_{2} \mathrm{O}$. Omichi et a1. (23) measured the vapor pressure over $\mathrm{LiCrO}_{2}$ using a mass spectrometer associated with a Pt Knudsen cell with the following result:

$$
\begin{aligned}
& \text { for } T=1673-1873(\mathrm{~K}) \\
& \qquad \log P_{L i}(\mathrm{~Pa})=-\left(22.41 \times 10^{3} / \mathrm{T}\right)+11.95
\end{aligned}
$$

In addition, the partial pressures of $\mathrm{Cr}, \mathrm{CrO}$, and $\mathrm{CrO}_{2}$ were determined al though much less than that of Li.

\subsection{THERMAL CONDUCTIVITY}

\subsubsection{Li-0 SYSTEM}

Takahashi and Kikuchi ${ }^{(24)}$ reported thermal conductivity values for porous $\mathrm{Li}_{2} 0$ specimens over a temperature range of $200^{\circ}-900^{\circ} \mathrm{C}$. Their samples ranged from 70.8 to $93.4 \%$ theoretical density (TD) for $99 \%$ pure $\mathrm{Li}_{2} \mathrm{O}$, with an average crystallite size of $20 \mu \mathrm{m}$ for $79.8 \%$ TD and $60 \mu \mathrm{m}$ for $93.4 \%$ TD. Their results are illustrated in Figure 4.4.1.1. They measured the material's thermal diffusivity by the laser pulse method under a vacuum environment. The value of the thermal conductivity, $k$, was then determined from the equation: 


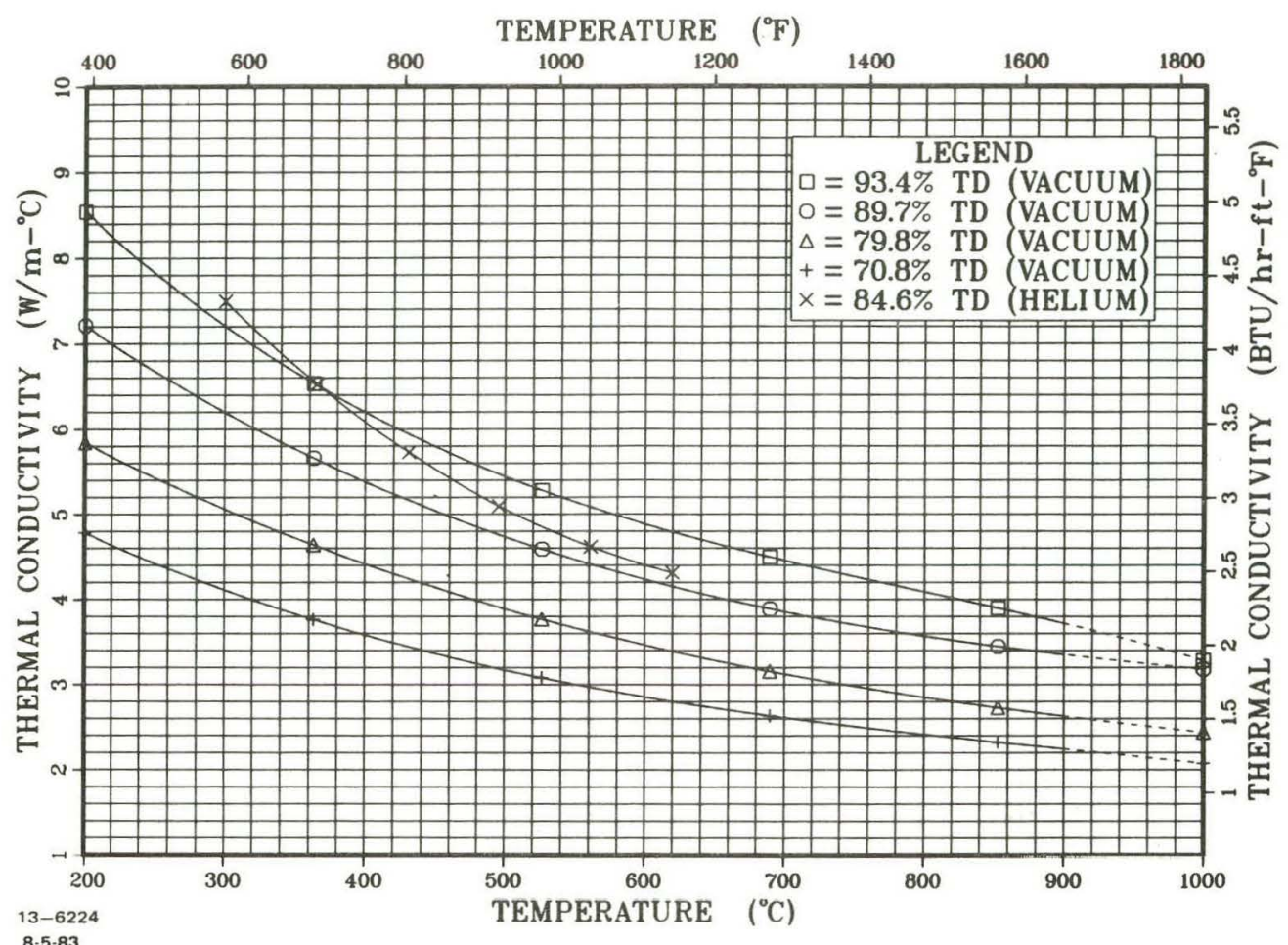

Figure 4.4.1.1 Thermal Conductivity of Polycrystalline $\mathrm{Li}_{2} \mathrm{O}$

$$
k_{n}=4.184 \alpha_{n} C_{p} \rho_{n}
$$

where

$$
\begin{aligned}
& k_{n}=\text { thermal conductivity }(\mathrm{W} / \mathrm{cm}-\mathrm{k}) \\
& \alpha_{n}=\text { thermal diffusivity }\left(\mathrm{cm}^{2} / \mathrm{sec}\right) \\
& c_{p}=\text { specific heat capacity }(\mathrm{cal} / \mathrm{g}-\mathrm{K}) \\
& \rho_{n}=\text { bulk density }\left(\mathrm{g} / \mathrm{cm}^{3}\right)
\end{aligned}
$$

$C_{p}$ values were taken from the literature, ${ }^{(25)}$ and they were obtained by extrapolation above $777 \mathrm{~K}$. The curve is portrayed in Section 4.5 of this report.

Hollenberg ${ }^{(26)}$ reported $k$ values for a $84.6 \%$ TD $\mathrm{Li}_{2} \mathrm{O}$ sample with an average grain size of $6 \mu \mathrm{m}$. His values, taken in a He environment, are plotted in Figure 4.4.1.1 and show a similar trend to the values taken in a vacuum environment with much larger grain sizes. The decrease in thermal conductivity with increasing temperature is consistent with the phonon conduction mechanism. At low temperatures, the mean free path of a phonon is equal to several unit cell lengths and is only slightly affected by defects. At high temperatures, however, the phonon's mean free path approaches unit cell dimensions and greater influenced by thermal defects. 


\section{$4.4 .2 \quad \mathrm{Li}_{2} \mathrm{O}-\mathrm{Al}_{2} \mathrm{O}_{3}$ SYSTEM}

Gurwe11 (27) presented a thermal conductivity curve for a mixed $\mathrm{LiAlO}_{2}$ (50 to $75 \% \gamma-\mathrm{LiAlO}_{2}$ and 25 to $50 \% \alpha-\mathrm{LiAlO}_{2}$ ) body at temperatures up to $1200 \mathrm{~K}$. The density was 1 isted as $88.5 \%$ of $2.62 \mathrm{~g} / \mathrm{cm}^{3}$ ( $\rho$ of a mixture of $\alpha$ and $\gamma-\mathrm{LiAlO}_{2}$ ) but there is no mention of test procedure, environment or grain size of the sample. The data have been presented in Figure 4.1.3.1.

Hollenberg ${ }^{(26)}$ measured the thermal conductivity of a high-purity, fine-grained $(<1 \mu \mathrm{m}) \gamma-\mathrm{LiAlO}_{2}(83.8 \% \mathrm{TD})$ by the laser pulse technique. The sample was coated with a thin layer of gold to provide an electrical conducting surface and to assure opaqueness to the laser beam. A chromel-alumel thermocouple was placed on the back face to measure the temperature rise after the $9 \mathrm{~kW}$ laser heated the front face. All measurements were made in $\mathrm{He}$ atmosphere to more closely approximate conditions in a tritium breeding blanket. The system's accuracy was established to be within $5 \%$ by measurements made on 316 SS. His findings have also been shown in Figure 4.4.2.1, and although fairly different $O \mathrm{RT}$, the difference decreases by the time $\mathrm{T}=500^{\circ} \mathrm{C}$ and the curves converge readily at higher temperatures.

Their results:

$$
\begin{aligned}
& \text { for } T=100^{\circ}-827^{\circ} \mathrm{C} \text { (Gurwe11's) } \\
& k\left(W / \mathrm{m}^{\circ}-\mathrm{C}\right)=3.59-6.85 \times 10^{-3} \mathrm{~T}+1.02 \times 10^{-5} \mathrm{~T}^{2} \\
& \text { for } T=100^{\circ}-600^{\circ} \mathrm{C} \text { (Hollenberg's) } \\
& k\left(W / \mathrm{m}^{\circ}-\mathrm{C}\right)=5.75-1.79 \times 10^{-2} \mathrm{~T}+3.41 \times 10^{-5} \mathrm{~T}^{2}
\end{aligned}
$$

\section{$4.4 .3 \quad \mathrm{Li}_{2} \mathrm{O}-\mathrm{SiO}_{2}$ SYSTEM}

Hollenberg ${ }^{(26)}$ followed the same procedure discussed in the previous section while investigating $\mathrm{Li}_{4} \mathrm{SiO}_{4}{ }^{\circ}$ His data, presented in Figure 4.4.3.1, again showed a relatively low, $\mathrm{k}_{n}$, fur $\mathrm{Li}_{4} \mathrm{SiO}_{4}$ although one higher than that of the $\gamma-\mathrm{LiAlO}_{2}$ sample. 


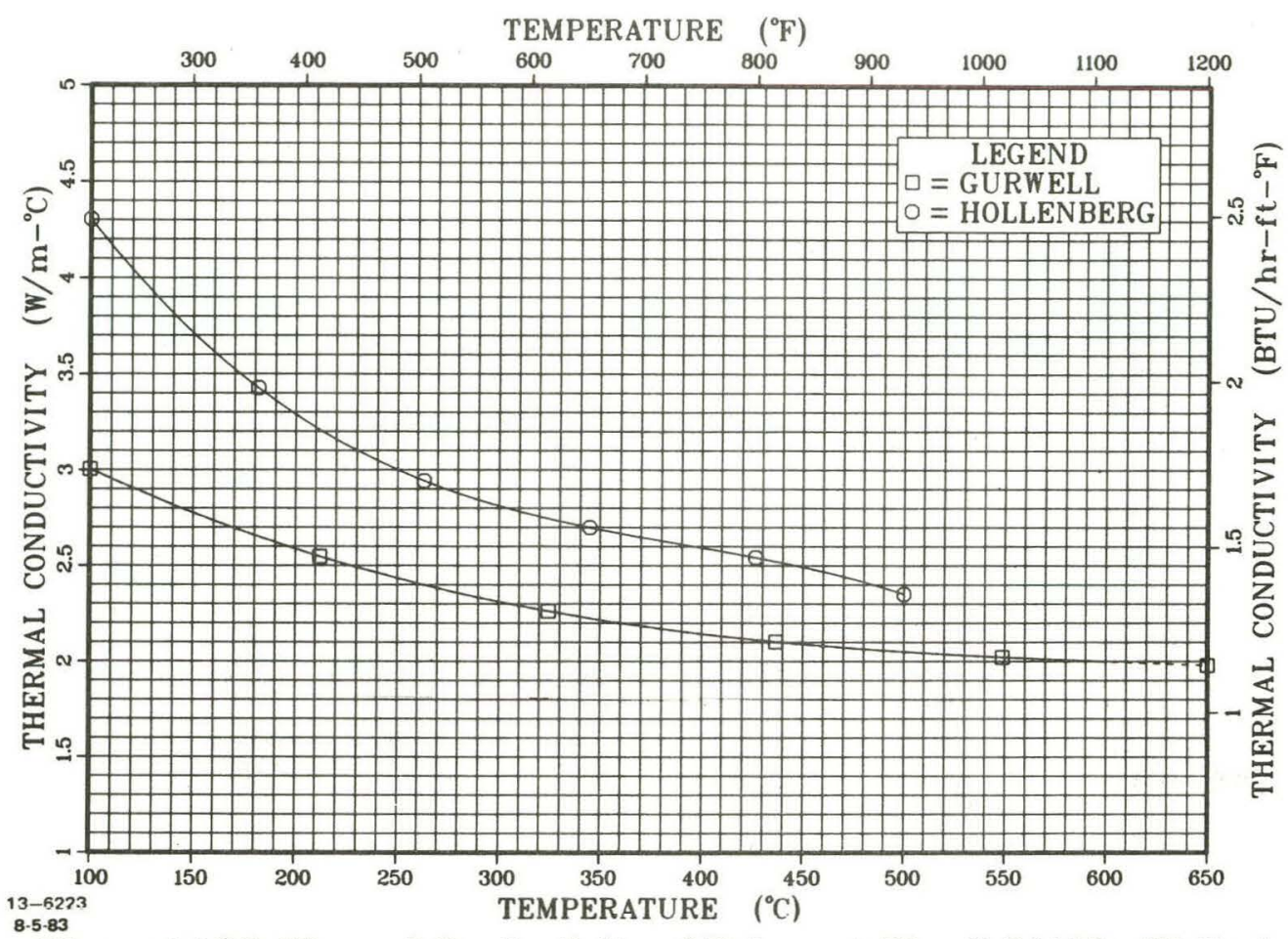

Figure 4.4.2.1 Thermal Conductivity of Polycrystalline $\gamma$ - $\mathrm{LiAlO}_{2}$ (Hollenberg's Data Was Taken in a He Environment While Gurwell's Was Not Stated)

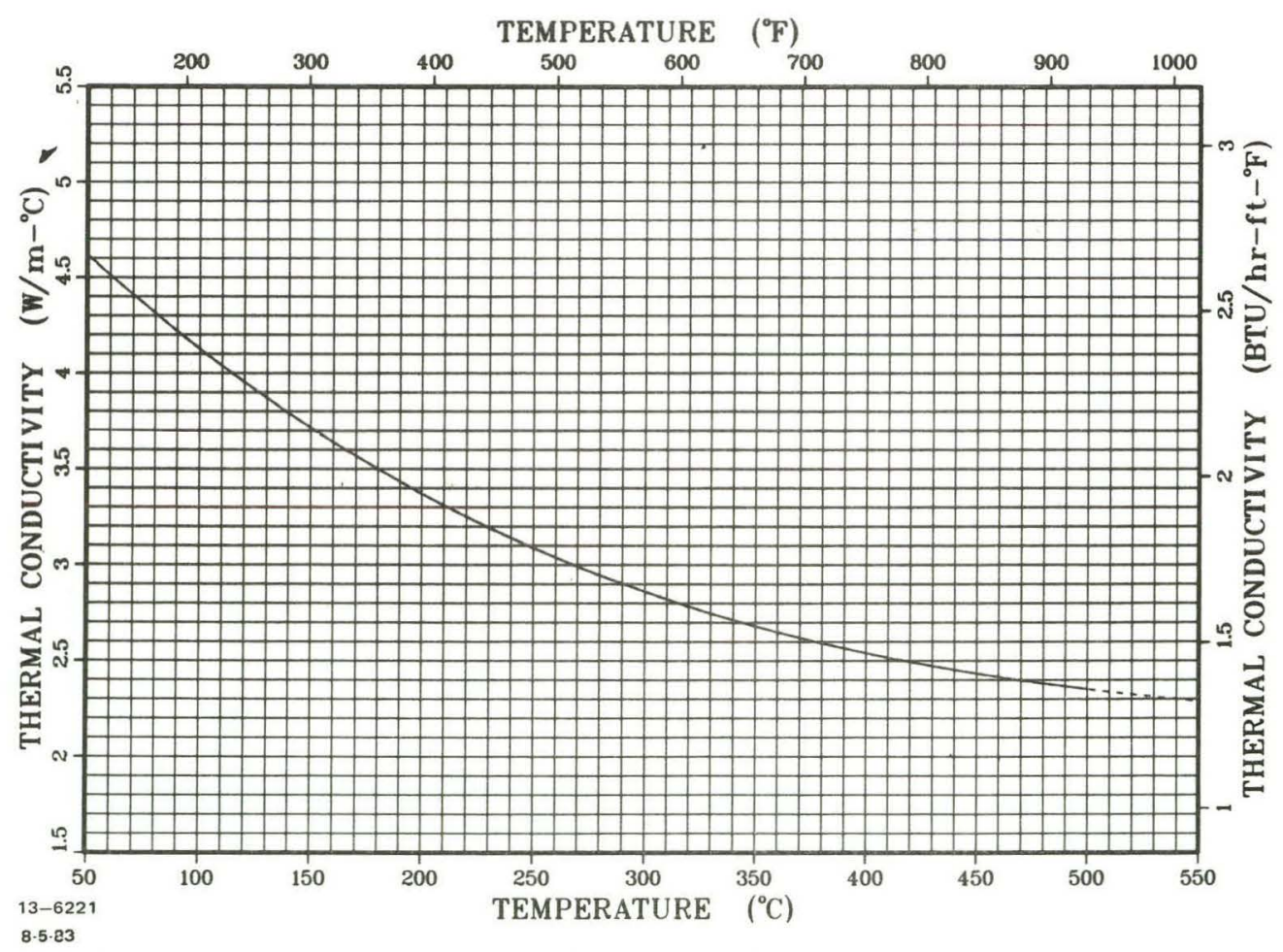

Figure 4.4.3.1 Thermal Conductivity of Polycrystalline $\mathrm{Li}_{4} \mathrm{SiO}_{4}$ in a He Environment 
The equation for $\mathrm{T}=50^{\circ}-500^{\circ} \mathrm{C}$ is:

$$
k\left(W / m-{ }^{0} \mathrm{C}\right)=5.19-1.23 \times 10^{-2} \mathrm{~T}+1.81 \times 10^{-5} \mathrm{~T}^{2}
$$

His sample was $85 \%$ TD with a grains size of $2 \mu \mathrm{m}$ and the data was generated under a He environment.

\subsection{4 $\mathrm{Li}_{2} \mathrm{O}-\mathrm{TiO}_{2}$ SYSTEM}

Finn and her coworkers ${ }^{(28)}$ examined the thermal conductivity of $\mathrm{Li}_{2} \mathrm{TiO}_{3}$ (81.4\% TD) using the laser pulse technique under a vacuum environment. Their data has been illustrated in Figure 4.4.1 and reveal very little temperature response over $200^{\circ}-1000^{\circ} \mathrm{C}$ range. The sample was cold pressed at $0.4 \mathrm{GPa}$ and sintered 0 $1693 \mathrm{~K}$ for 4 hours in vacuum. The final average crystallite (grain) size was $110 \mu \mathrm{m}$ with connected pores at least $50 \mu \mathrm{m}$ in size. Also noticed was the presence of a glassy phase and a closed porosity of $2 \%$. The sample was coated with carbon to insure uniform absorption and preheated to $800^{\circ} \mathrm{C}$ in vacuum prior to test.

The equation that describes the curve for $\mathrm{T}=100^{\circ}-1000^{\circ} \mathrm{C}$ is:

$$
\mathrm{k}\left(\mathrm{W} / \mathrm{m}-{ }^{0} \mathrm{C}\right)=1.885-8.28 \times 10^{-4} \mathrm{~T}+3.69 \times 10^{-7} \mathrm{~T}^{2}
$$

\section{$4.4 .5 \quad \mathrm{Li}_{2} \mathrm{O}-\mathrm{ZrO}_{2}$ SYSTEM}

Hollenberg ${ }^{(3)}$ followed the same procedure outlined in section 4.4 .2 to determine the thermal conductivity of $\mathrm{Li}_{2} \mathrm{ZrO}_{3}$ samples by the laser pulse method under He atmosphere. One sample was cold pressed and sintered to 78.9\% TD in a He atmosphere while the other was hot pressed to $85 \%$ TD with a average grain size of $2 \mu \mathrm{m}$. Grain size and pore size were not reported but the data have been depicted in Figure 4.4.5.1.

Finn, et al. (4) determined the thermal diffusivity of $\mathrm{Li}_{2} \mathrm{ZrO}_{3}$ and plotted its thermal conductivity in Figure 4.4.5.1. The measurements were made in vacuum and can be compared to those made in He with a factor of 2 difference. Significant microcracking was observed which in part is responsible for the low thermal conductivity. In addition, a hysteresis effect was seen which could be the result of a crack healing process or of glassy phase formation. 


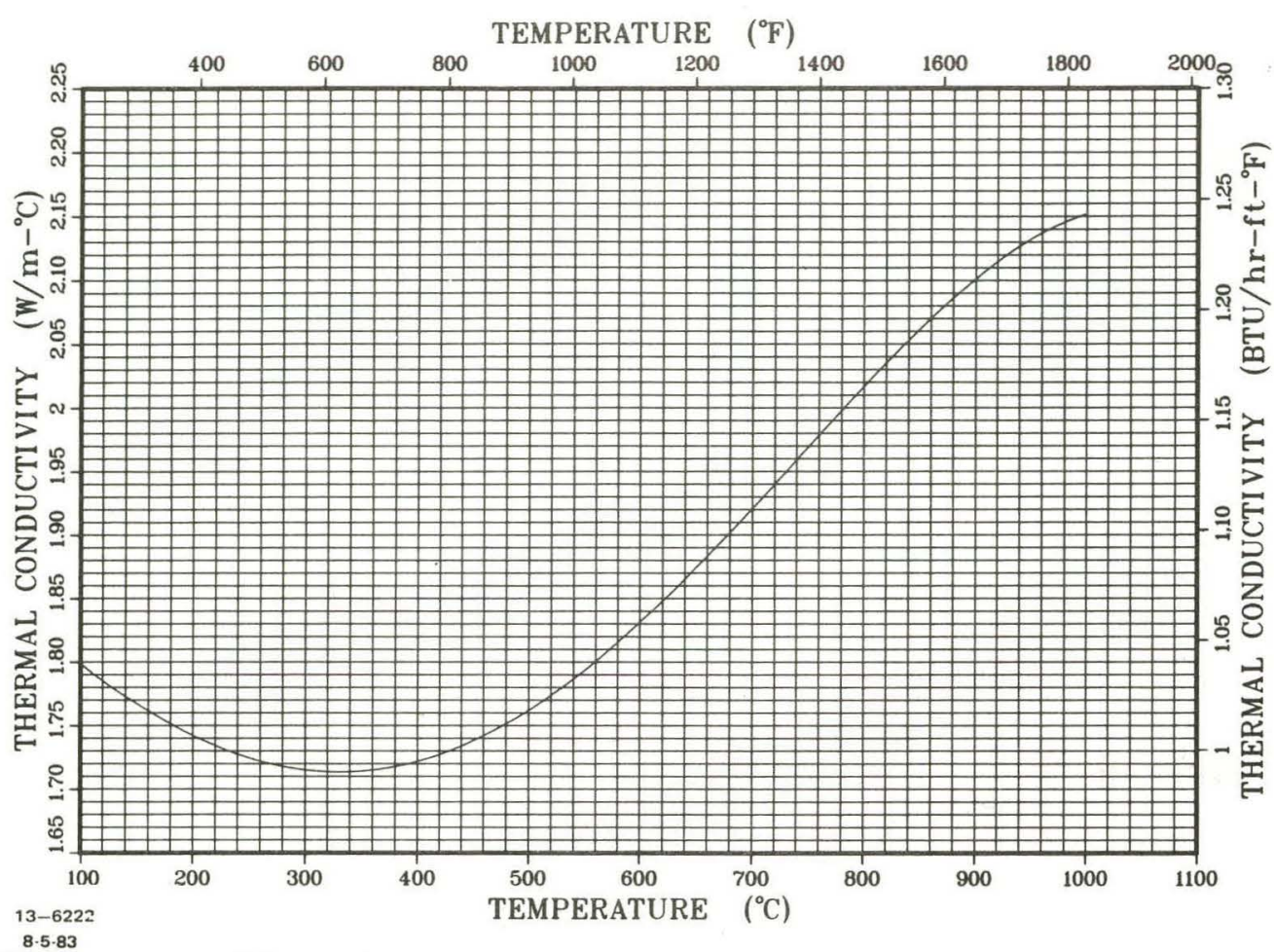

Figure 4.4.4.1 Thermal Conductivity of Polycrystalline $\mathrm{Li}_{2} \mathrm{TiO}_{3}$ in a Vacuum Environment

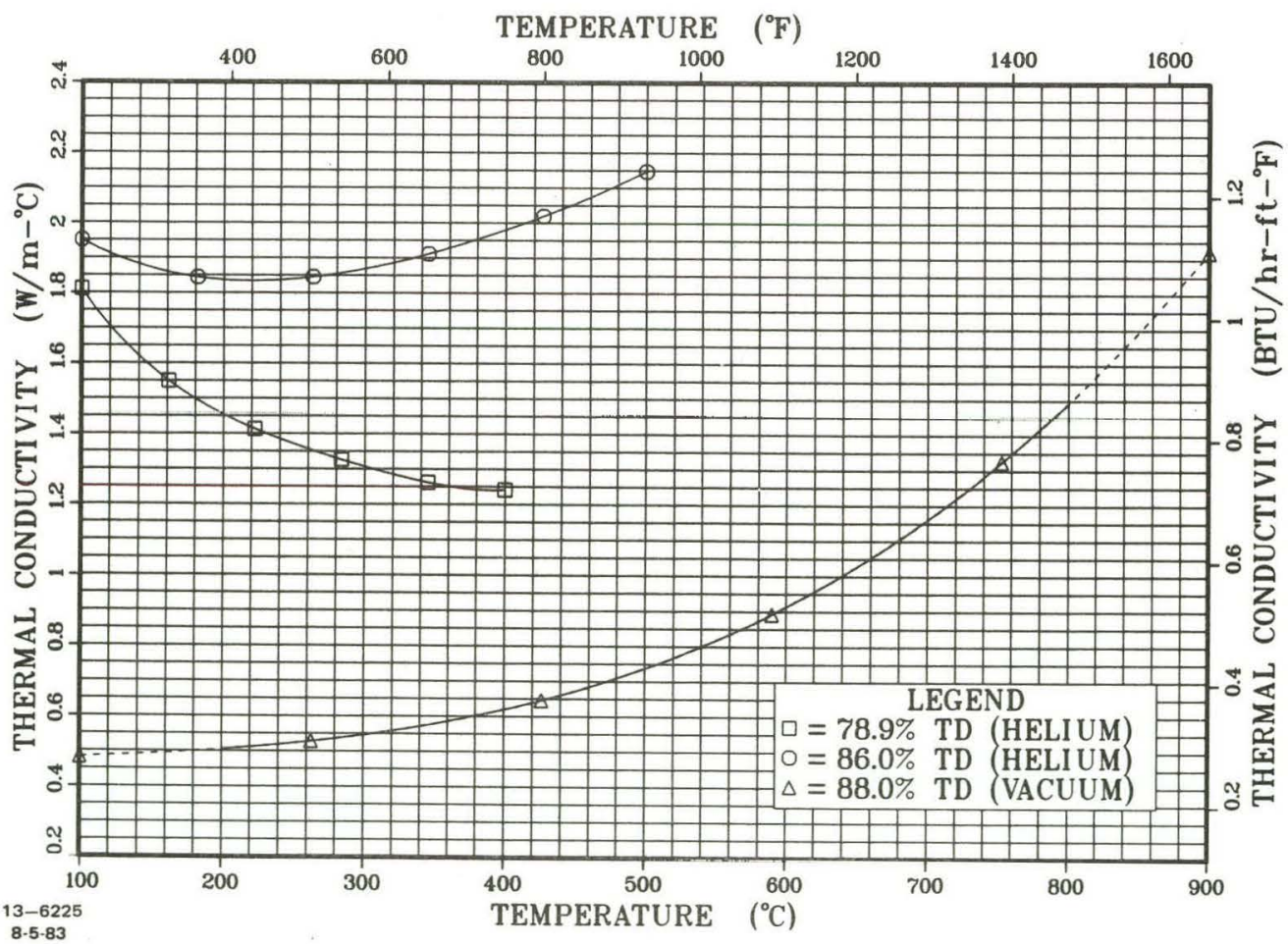

Figure 4.4.5.1 Thermal Conductivity of Polycrystalline $\mathrm{Li}_{2} \mathrm{ZrO}_{3}$ Bodies 
The equations that describe the results are:

$$
\begin{aligned}
& 78.9 \% \mathrm{TD}-(\mathrm{He})-\mathrm{T}=100^{\circ}-400^{\circ} \mathrm{C} \\
& \mathrm{k}\left(\mathrm{W} / \mathrm{m}-{ }^{0} \mathrm{C}\right)=2.86-1.63 \times 10^{-2} \mathrm{~T}+7.42 \times 10^{-5} \mathrm{~T}^{2} \\
& 86 . \% \mathrm{TD}-(\mathrm{He})-\mathrm{T}=100^{\circ}-500^{\circ} \mathrm{C} \\
& \mathrm{k}\left(\mathrm{W} / \mathrm{m}^{\circ}{ }^{\circ} \mathrm{C}\right)=2.32-5.41 \mathrm{~T}+2.00 \mathrm{~T}^{2} \\
& 88 \% \mathrm{TD}-(\text { Vacuum })-\mathrm{T}=100^{0}-800^{0} \mathrm{C} \\
& \mathrm{k}\left(\mathrm{W} / \mathrm{m}^{\circ}{ }^{0} \mathrm{C}\right)=4.65 \times 10^{-1}+1.87 \times 10^{-4} \mathrm{~T}-3.79 \times 10^{-7} \mathrm{~T}^{2}
\end{aligned}
$$

\subsubsection{Li ${ }_{2} 0-$ METAL OXIDE SYSTEMS}

A comparison of the thermal conductivity values for the various solid breeder candidates has been made in Figure 4.4.6.1. The data for the majority was generated in a blanket-like He environment except for $\mathrm{Li}_{2} \mathrm{TiO}_{3}$. At lower temperatures, $\mathrm{Li}_{2} \mathrm{O}$ has much higher values but at higher temperatures $\left(>500^{\circ} \mathrm{C}\right.$ )

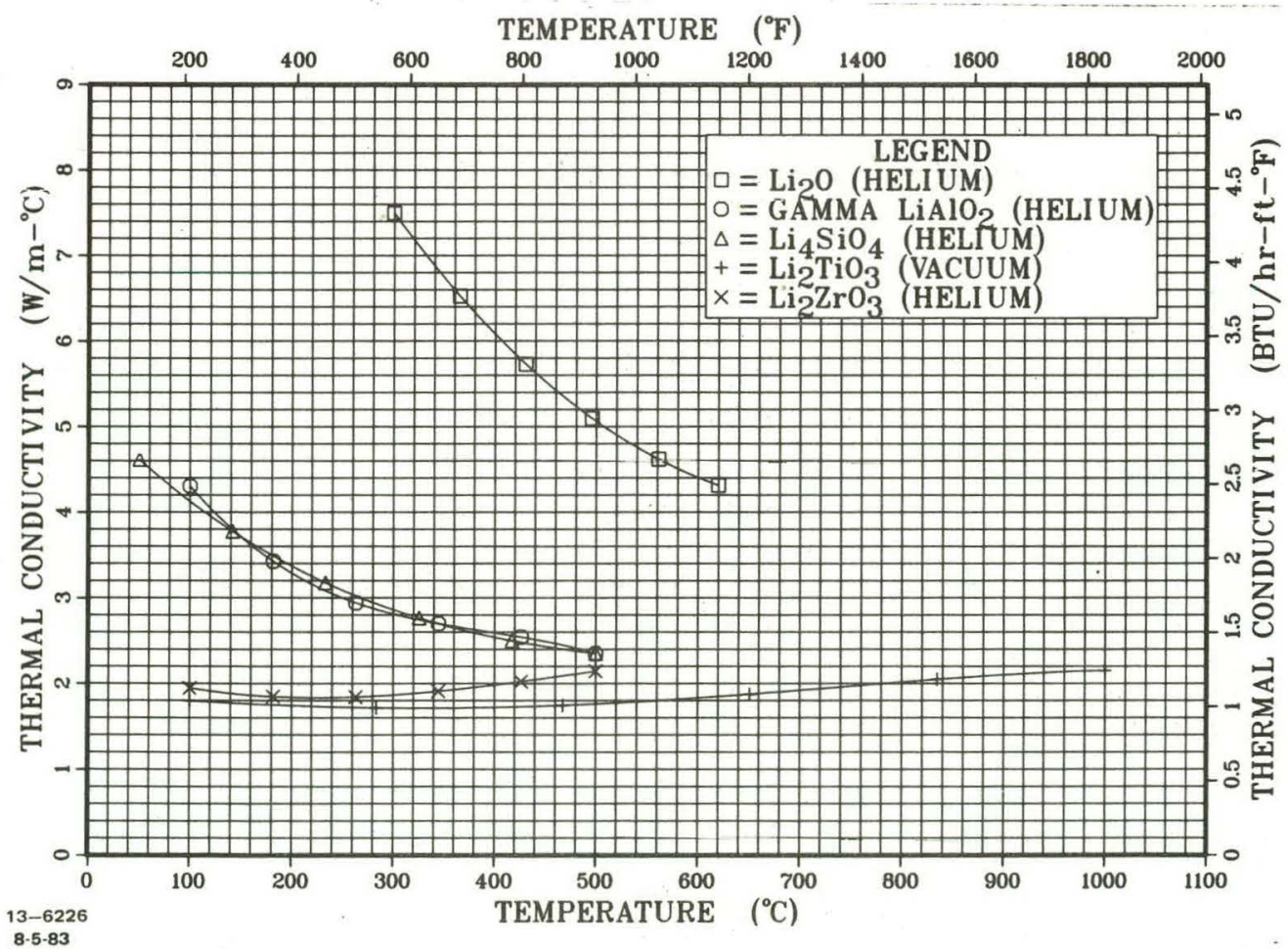

Figure 4.4.6.1 Comparison of Thermal Conductivity Values for Various Solid Breeder Candidates 
the differences narrow if the curves were extrapolated. An interesting trend is the slightly increasing values for $\mathrm{Li}_{2} \mathrm{TiO}_{3}$ in a vacuum appears to have very little change although another slightly upward trend is noticed. If evaluated in a He environment, $\mathrm{Li}_{2} \mathrm{TiO}_{3}$ would probably be two to three times higher, similar to the relationship "seen" for $\mathrm{Li}_{2} \mathrm{ZrO}_{3}$.

\subsection{SPECIFIC HEAT}

\subsubsection{Li-0 SYSTEM}

The specific heat of $L i_{2} 0$ has been studied by several investigators. Johnston and Bauer $(29)$ produced $\mathrm{Li}_{2} \mathrm{O}$ from the decomposition reaction of $\mathrm{LiOH}$ in a reducing atmosphere and further heated the $\mathrm{Li}_{2} \mathrm{O}$ in a $\mathrm{Ni}$ boat until it was $99.9 \%$ pure. They used the drop calorimetry method and determined the heat capacity from 16 to $304 \mathrm{~K}$. Their equation was

$$
\operatorname{Cp}(\mathrm{cal} / \mathrm{mol})=-0.501-0.02167 \mathrm{~T}+0.37356(1000 / \mathrm{T})^{3}
$$

More useful data have been gathered by Tanifuji et al., (30) Barin and Knacke ${ }^{(31)}$, Shomate and Cohen, ${ }^{(25)}$ and Rodigina and Gomelskij ${ }^{(32)}$ for $\mathrm{Li}_{2} \mathrm{O}$. Tanifuji performed the latest work, which was in excellent agreement with the others. The work of Tanifji et al., was done with an adiabatic scanning calorimeter, whereas the others chose the drop calorimetry technique. The data are in such good agreement that only Tanifuji's values has been plotted on Figure 4.5.1.1. His equation was

$$
\mathrm{Cp}(\mathrm{J} / \mathrm{kg}-\mathrm{K})=2.518 \times 10^{3}+0.333 \mathrm{~T}-8.382 \times 10^{7} \mathrm{~T}^{-2}
$$

for a temperature range of 306-1073 K.

\section{$4.5 .2 \quad \mathrm{Li}_{2} \mathrm{O}-\mathrm{Al}_{2} \mathrm{O}_{3}$ SYSTEM}

Hollenberg ${ }^{(26)}$ and Christensen et al. (33) have made measurements on $\mathrm{LiAlO}_{2}$ over the temperature range of interest. Both results are plotted in Figure 


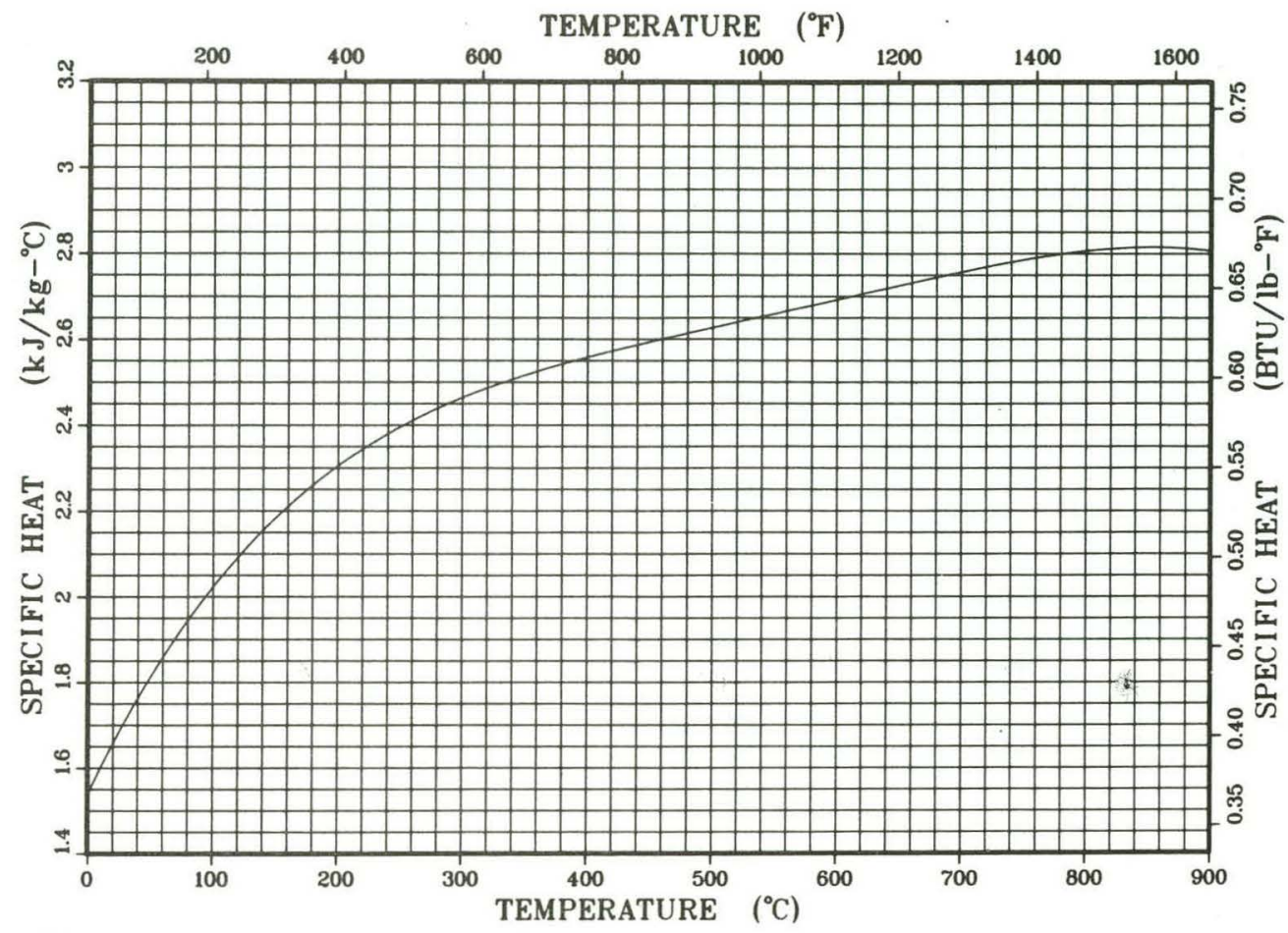

$13-6272$

Figure 4.5.1.1 Specific Heat of $\mathrm{Li}_{2} \mathrm{O}$

4.5.2.1 with Hollenberg's being slightly lower ( $\approx 10 \%)$ than Christensen's values. Hollenberg measured a pure $\gamma-\mathrm{LiAlO}_{2}$ sample with a Hewlett-Packard DSC-II scanning calorimeter using a sapphire standard. Christensen used the drop calorimetry method for his measurements and may have had a mixed phase of $\mathrm{LiAlO}_{2}$ for his sample. This might account for his slighly higher measurements. Christensen's equations was:

$$
\mathrm{Cp}(\mathrm{J} / \mathrm{kg}-\mathrm{K})=0.335+4.39 \times 10^{-5} \mathrm{~T}-9.10 \times 10^{3} \mathrm{~T}^{-2}
$$

for a temperature in the 298-1800 K range. Hollenberg's was

$$
\mathrm{Cp}(\mathrm{J} / \mathrm{kg}-\mathrm{K})=1.047 \times 10^{3}+0.402 \mathrm{~T}-1.800 \times 10^{7} \mathrm{~T}^{-2}
$$

which covered a range of $398-700 \mathrm{~K}$.

\section{$4.5 .3 \quad \mathrm{Li}_{2} \mathrm{O}-\mathrm{SiO}_{2}$ SYSTEM}

Hollenberg (26) and Bennington et al. (34) have determined the specific heat for various lithium silicates. In Hollenberg's experiment, the $\mathrm{Li}_{4} \mathrm{SiO}_{4}$ 


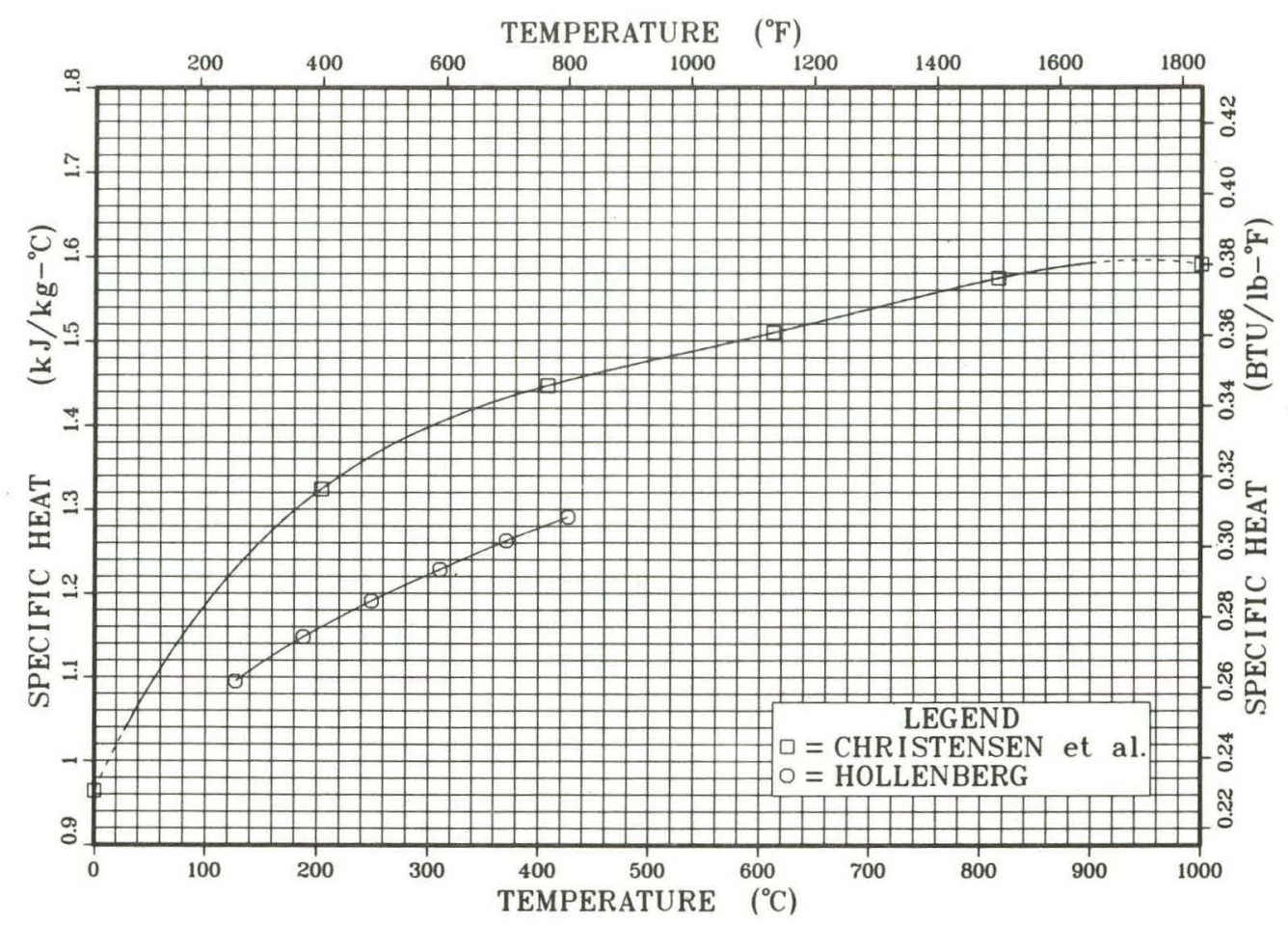

Figure 4.5.2.1 Specific Heat of $\gamma \cdot \mathrm{LiAlO}_{2}$

sample had a phase impurity of $\mathrm{Li}_{2} \mathrm{SiO}_{3}$ (1-t wt.\%), while Bennington's samples of $\mathrm{Li}_{2} \mathrm{SiO}_{3}$ and $\mathrm{Li}_{2} \mathrm{Si}_{2} \mathrm{O}_{5}$ were reported to be phase pure. Hollenberg's technique has been described in Section 4.5.2, and his equation for the specific heat of $\mathrm{Li}_{4} \mathrm{SiO}_{4}$ was:

$$
C p(\mathrm{~J} / \mathrm{kg}-\mathrm{K})=9.399 \times 10^{2}+1.458 \mathrm{~T}+4.011 \times 10^{6} \mathrm{~T}^{-2}
$$

from 373-773 $\mathrm{K}$ and has been illustrated in Figure 4.5.3.1.

Bennington and his coworkers $(34)$ employed the drop calorimetry method in determining the $\mathrm{Cp}$ values of both $\mathrm{Li}_{2} \mathrm{SiO}_{3}$ and $\mathrm{Li}_{2} \mathrm{Si}_{2} \mathrm{O}_{5}$. Their results are plotted in Figure 4.5.3.1. Their equations are:

$$
\mathrm{Cp}\left(\mathrm{kJ} / \mathrm{kg}-{ }^{\circ} \mathrm{C}\right)-1.069+2.417 \times 10^{-3} \mathrm{~T}-3.641 \times 10^{-6} \mathrm{~T}^{2}
$$

for $\mathrm{Li}_{2} \mathrm{SiO}_{3}$ fronii $25-325^{\circ} \mathrm{C}$, and

$$
\mathrm{Cp}\left(\mathrm{kJ} / \mathrm{kg}^{\circ}{ }^{\circ} \mathrm{C}\right)=9.16 \times 10^{-1}+2.172 \times 10^{-3} \mathrm{~T}-3.118 \times 10^{-6} \mathrm{~T}^{2}(61)
$$

for $\mathrm{Li}_{2} \mathrm{Si}_{2} \mathrm{O}_{5}$ from $25-825^{\circ} \mathrm{C}$ 


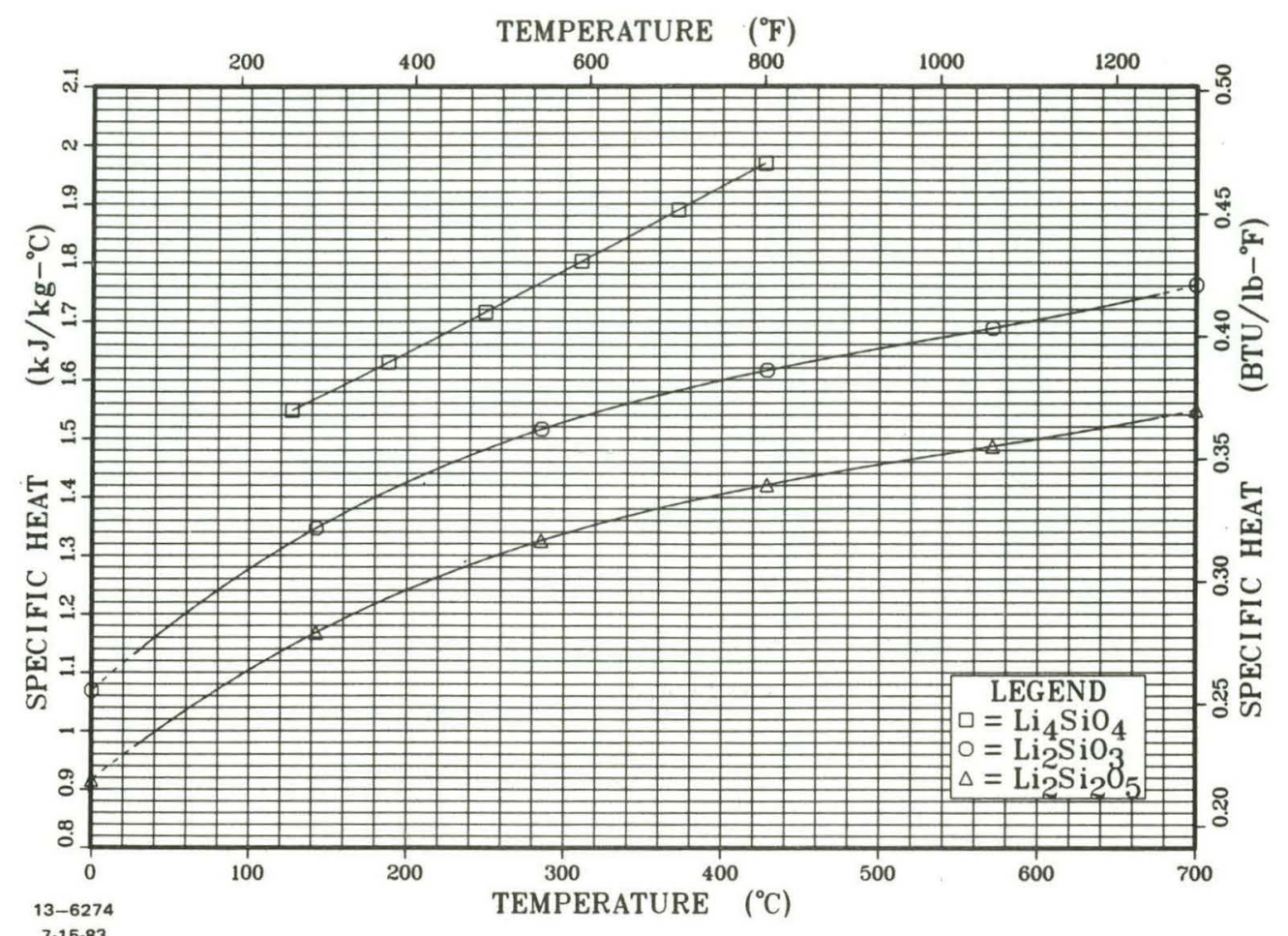

Figure 4.5.3.1 Specific Heat of Compounds in the $\mathrm{Li}_{2} \mathrm{O}-\mathrm{SiO}_{2}$ System

\section{$4.5 .4 \quad \mathrm{Li}_{2} \mathrm{O}-\mathrm{TiO}_{2}$ SYSFEM}

Christensen, et.a1., (33) reported the values plotted in Figure 4.5.4.1 for $\mathrm{Li}_{2} \mathrm{TiO}_{3}$. A $\alpha \rightarrow \beta$ phase transition was seen in this system but it occurred 0 $1485 \mathrm{~K}$, a temperature well above the normal range of a breeding blanket. They used the drop calorimetry method and covered the temperature range $25^{\circ}-900^{\circ} \mathrm{C}$. Their equation was:

$$
\mathrm{Cp}\left(\mathrm{kj} / \mathrm{kg}^{\circ}{ }^{\circ} \mathrm{C}\right)=9.732 \times 10^{-1}+1.599 \times 10^{-3} \mathrm{~T}-2.25 \times 10^{-6} \mathrm{~T}^{2}(62)
$$




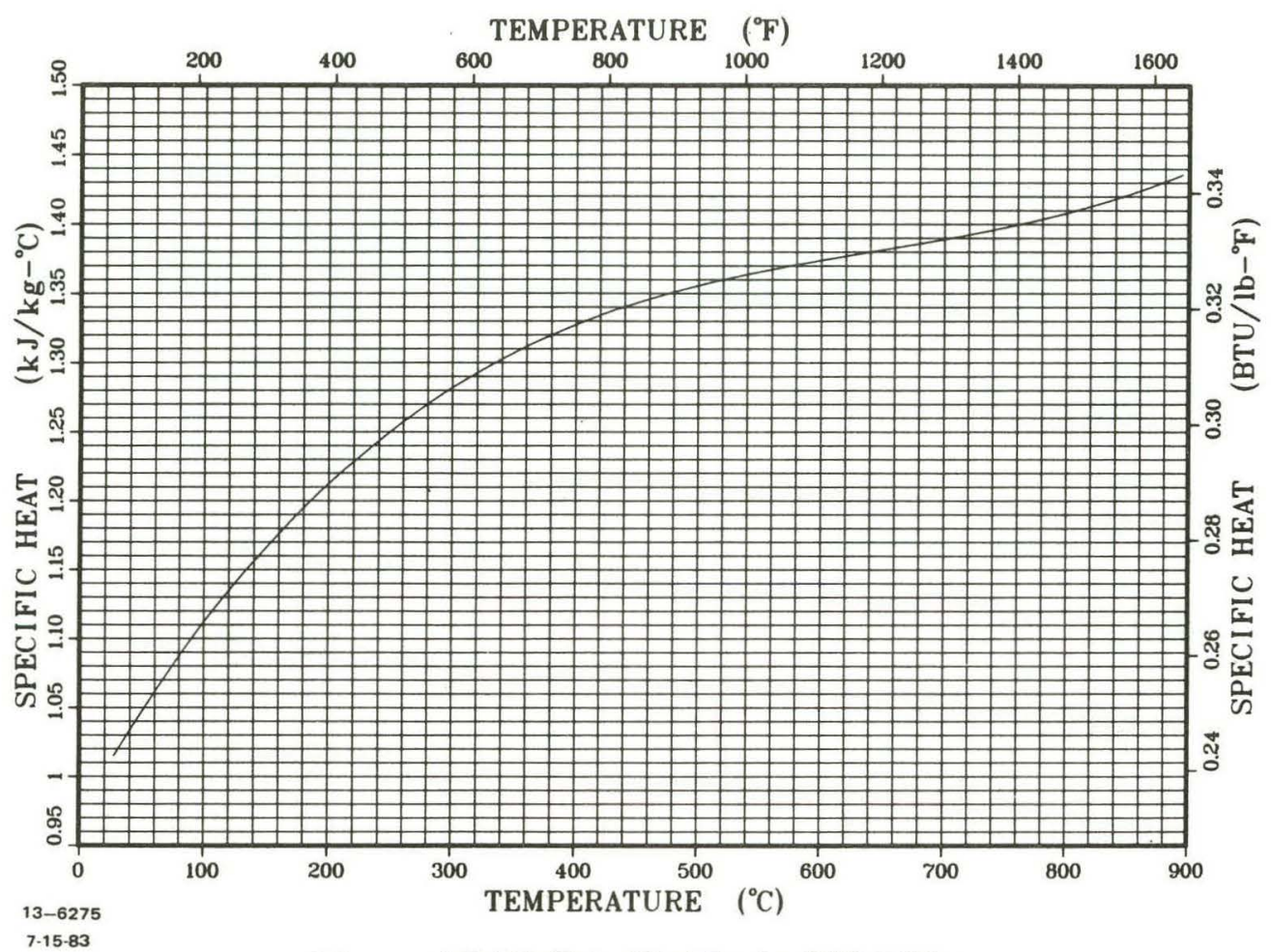

Figure 4.5.4.1 Specific Heat of $\mathrm{Li}_{2} \mathrm{TiO}_{3}$

\section{$4.5 .5 \quad \mathrm{Li}_{2} \mathrm{O}-\mathrm{ZrO}_{2}$ SYSTEM}

Barin and Knacke ${ }^{(31)}$ and Hollenberg ${ }^{(26)}$ both reported $\mathrm{Cp}$ values for monoclinic $\mathrm{Li}_{2} \mathrm{ZrO}_{3}$. Hollenberg used a phase pure material and a scanning DSC-II calorimeter to achieve almost identical values to those theoretically predicted by Barin. Hollenberg's equation was

$$
\mathrm{Cp}(\mathrm{J} / \mathrm{kg}-\mathrm{K})=7.494 \times 10^{2}+0.312 \mathrm{~T}
$$

from 373-773 K. The plot on Figure 4.5.5.1 utilizes Hollenberg's and Barin's data to extend the curve to $400^{\circ} \mathrm{C}$. The curve is smooth, indicating no phase transitions; this finding is in agreement with other investigators who report the monoclinic - tetragonal phase change occurring $01100^{\circ} \mathrm{C}$ or $1373 \mathrm{~K}$. 


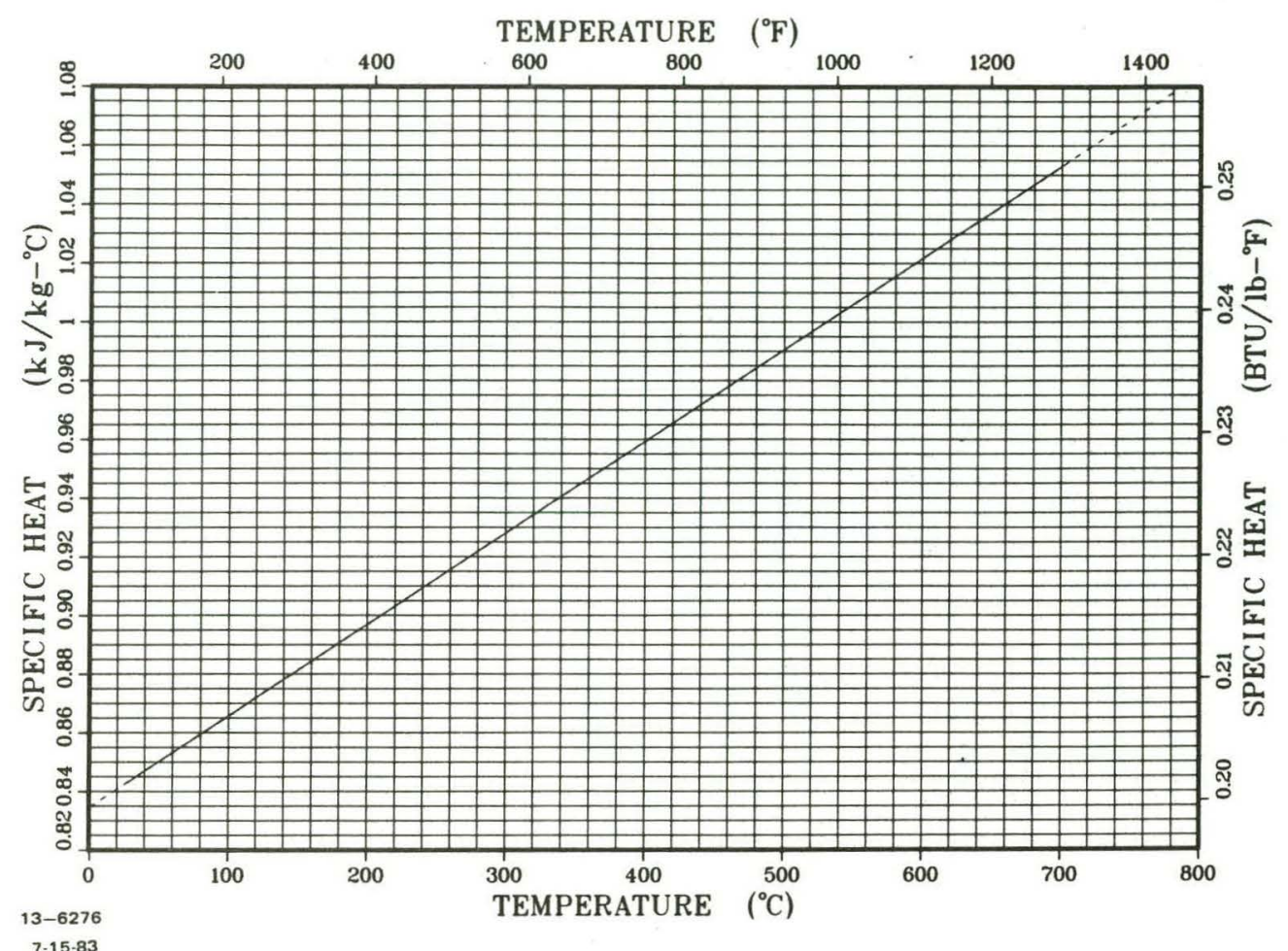

Figure 4.5.5.1 Specific Heat of $\mathrm{Li}_{2} \mathrm{ZrO}_{3}$

\subsection{THERMAL EXPANSION}

\subsubsection{Li-0 System}

Hollenberg ${ }^{(26)}$ measured the thermal expansion of a Li 0 pellet with a Theta Dilatronic dilatometer in an inert atmosphere using a platinum standard for calibration. Several runs were made to insure that sintering, hysteresis, or swelling had not occurred and affected the results. The pellet was produced by hot pressing to $85 \%$ TD with an average crystallite size of $6 \mu \mathrm{m}$. His results have been illustrated in Figure 4.6.1.1 with the major portion of the curve being expressed as

$$
\operatorname{LTE}(\%)=-5.707 \times 10^{-4}+2.081 \times 10^{-3} \mathrm{~T}+8.388 \times 10^{-7} \mathrm{~T}^{2}
$$

over a temperature range of $100^{\circ} \mathrm{C}$ to $1000^{\circ} \mathrm{C}$.

Kurasawa et.a1. (35) examined the linear thermal expansion of a single crystal of $\mathrm{Li}_{2} \mathrm{O}$ prepared by the floating zone growth method using an infrared imaging 
furnace. Their results have been depicted in Figure 4.6.1.1 and are very close to the data of Hollenberg's $85 \%$ TD polycrystalline sample.

$$
\operatorname{LTE}(\%)=8.417 \times 10^{-4}+1.26 \times 10^{-3} \mathrm{~T}+2.72 .6 \times 10^{-6} \mathrm{~T}^{2}
$$

This was consistant with the findings of little variation for sintered pellets of $\mathrm{Li}_{2} \mathrm{O}$ with densities ranging from 75.5 to $92.5 \%$ TD except at temperatures above $800^{\circ} \mathrm{C}$.

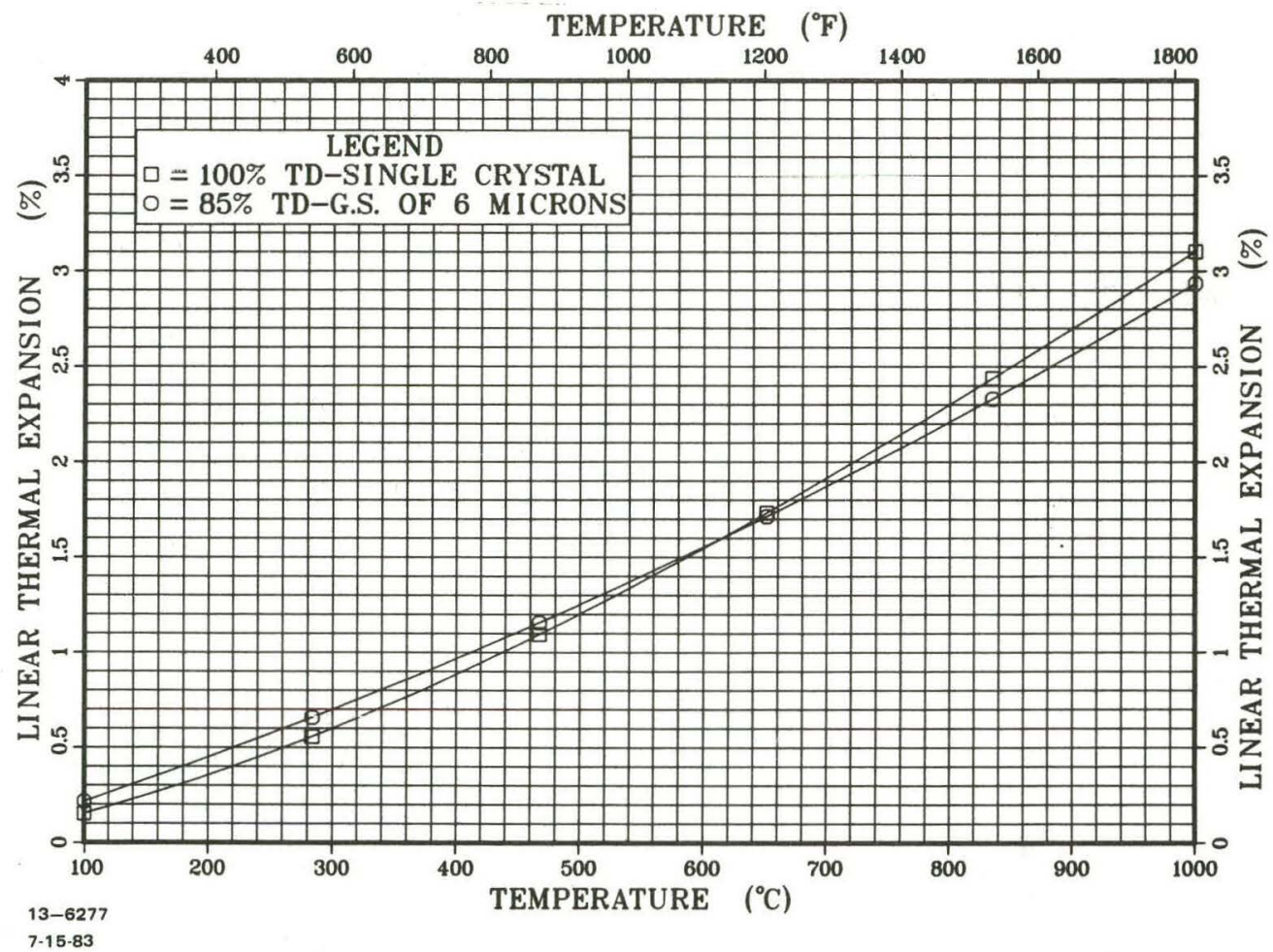

Figure 4.6.1.1 Linear Thermal Expansion of Single Crystal and Polycrystalline $\mathrm{Li}_{2} \mathrm{O}$

\subsection{2 $\mathrm{Li}_{2} \mathrm{O}-\mathrm{Al}_{2} \mathrm{O}_{3}$ SYSTEM}

Hollenberg ${ }^{(26)}$ and Hummel ${ }^{(36)}$ have both measured the thermal expansion of $\gamma$-LiAlO 2 samples. Hummel prepared his $\gamma-\mathrm{LiAlO}_{2}$ by solid state reaction o $1500^{\circ} \mathrm{C}$ for 7 to 15 hours. No mention was made of firing atmosphere but it was presumed to be air. After grinding, the $\gamma-\mathrm{LiAlO}_{2}$ was pressed with a binder and refired at $1500^{\circ} \mathrm{C}$ for 1 hour. At the time he presented his data, there were no previous works for comparison or verification. Consequently he believed his $x$-ray analysis to be that of pure $\gamma-\mathrm{LiAlO}_{2}$. However, his data 
contained three d-spacings, which have been shown not to be present in phase pure $\gamma-\mathrm{LiAlO}_{2}$. They are at $3.52,2.79$ and $1.52 \AA$. These peaks indicate the presence of a second phase, possibly $\mathrm{LiAl}_{5} \mathrm{O}_{8}$, due to $\mathrm{Li}_{2} \mathrm{O}$ volatilization at high temperatures.

Hollenberg hot-pressed a sample of $\gamma-\mathrm{LiAlO}_{2}$ and verified its phase purity against the JCPDS X-ray Diffraction Card File. His sample was made to $85 \%$ TD with an average grain size of $<1 \mu \mathrm{m}$. His data were obtained with a Theta Dilometer and closely matched the values presented by Hummel. Thus the data, in Figure 4.6.2.1, can be described using one equation:

$$
\operatorname{LTE}(\%)=3.750 \times 10^{-4}+9.604 \times 10^{-4} \mathrm{~T}+2.480 \times 10^{-7} \mathrm{~T}^{2}
$$

being useful from $100^{\circ}$ to $900^{\circ} \mathrm{C}$ for $\gamma-\mathrm{LiAlO}_{2}$.

In addition, Hummel ${ }^{(36)}$ measured the thermal expansion of $\mathrm{LiAl}_{5} \mathrm{O}_{8}$ and found

$$
\% \operatorname{LTE}(\%)=-4.883 \times 10^{-2}+8.443 \times 10^{-4} \mathrm{~T}-2.937 \times 10^{-7} \mathrm{~T}^{2}
$$

from $\mathrm{T}=100^{\circ}$ to $900^{\circ} \mathrm{C}$.

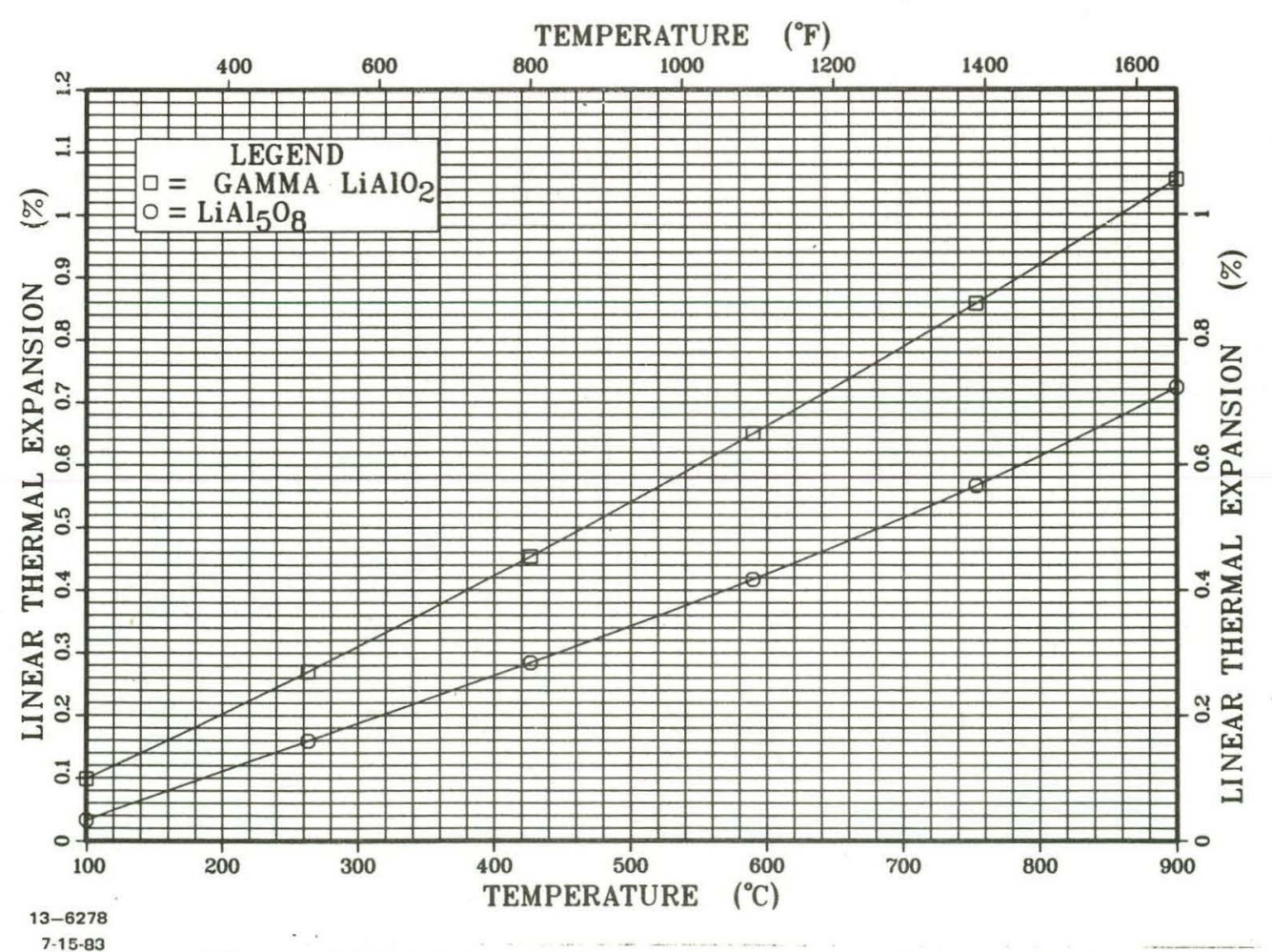

Figure 4.6.2.1 Linear Thermal Expansion Polycrystalline $\gamma=\mathrm{LiALO}_{2}$ and $\mathrm{LiAl}_{5} \mathrm{O}_{8}$. 


\subsection{3 $\mathrm{Li}_{2} \mathrm{O}-\mathrm{SiO}_{2} \mathrm{SYSTEM}$}

Soga (37) first reported the thermal expansion of $\mathrm{Li}_{4} \mathrm{SiO}_{4}$ from $25^{\circ}$ to $400^{\circ} \mathrm{C}$. He pressed and sintered his sample $01100^{\circ} \mathrm{C}$ for 3 hours and then used a BrinkmanNetzsch dilatometer for his measurements. No mention of final phase purity, chemistry or crystallite size was made. His data, was presented as

$$
\operatorname{LTE}(\%)=2.04 \times 10^{-3} \mathrm{~T}
$$

from $25^{\circ}$ to $400^{\circ} \mathrm{C}$. These data are not too much different from Hollenberg's data for the same temperature range. Hollenberg used a Theta Dilatometer with a Pt standard on a $\mathrm{Li}_{4} \mathrm{SiO}_{4}$ (85\% TD) sample which had an average grain size of $2 \mu \mathrm{m}$. His full range of data have been presented in Figure 4.6.3.1 with the relationship between $80^{\circ}$ and $900^{\circ} \mathrm{C}$ being expressed as

$$
\operatorname{LTE}(\%)=-4.786 \times 10^{-4}+1.881 \times 10^{-3} \mathrm{~T}+8.334 \times 10^{-7} \mathrm{~T}^{2}
$$

Kirchner et al. (38) reported the linear thermal expansion of $\mathrm{Li}_{2} \mathrm{SiO}_{3}$ and $\mathrm{Li}_{2} \mathrm{Si}_{2} \mathrm{O}_{5}$ with the following results:

$$
\begin{aligned}
& \mathrm{Li}_{2} \mathrm{SiO}_{3} \text { for } \mathrm{T}=100^{\circ} \text { to } 700^{\circ} \mathrm{C} \\
& \operatorname{LTE}(\%)=-1.124 \times 10^{-2}+1.129 \times 10^{-3} \mathrm{~T} \\
& \mathrm{Li}_{2} \mathrm{Si}_{2} \mathrm{O}_{5} \text { for } \mathrm{T}=100^{\circ} \text { to } 700^{\circ} \mathrm{C} \\
& \operatorname{LTE}(\%)=-2.943 \times 10^{-2}+7.196 \times 10^{-4} \mathrm{~T}+5.689 \times 10^{-7} \mathrm{~T}^{2}
\end{aligned}
$$




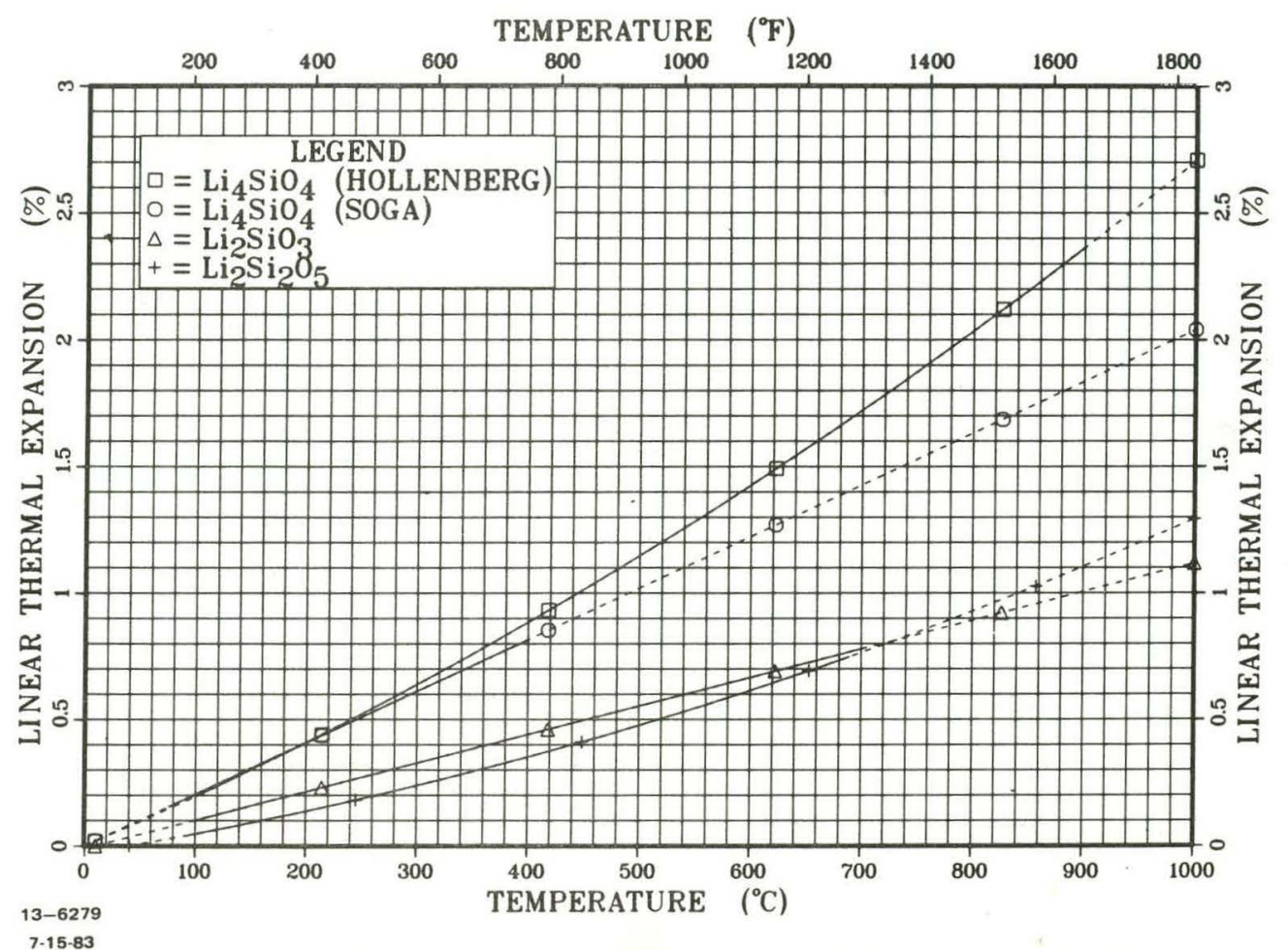

Figure 4.6.3.1 Linear Thermal Expansion of Compounds in the $\mathrm{Li}_{2} \mathrm{O}-\mathrm{SiO}_{2}$ System 


\subsection{4 $\mathrm{Li}_{2} \mathrm{O}-\mathrm{TiO}_{2}$ SYSTEM}

Girard and his co-workers ${ }^{(39)}$ examined $\mathrm{a} \mathrm{Li}_{2} \mathrm{TiO}_{3}$ body formulated to a high density with very little porosity. They were trying to duplicate the high density $\left(\approx 90 \%\right.$ ) achieved by plasma-spraying a coating of $\mathrm{Li}_{2} \mathrm{TiO}_{3}$ onto a metal surface. No further details were given as to the exact material density or purity or even test method. Their results have been plotted in Figure 4.6.4.1 with the following equation describing their results.

$$
\begin{aligned}
& \operatorname{LTE}(\%)=-5.573 \times 10^{-2}+1.455 \times 10^{-3} \mathrm{~T}+5.505 \times 10^{-7} \mathrm{~T}^{2} \\
& \text { for } \mathrm{T}=100^{\circ} \text { to } 800^{\circ} \mathrm{C}
\end{aligned}
$$

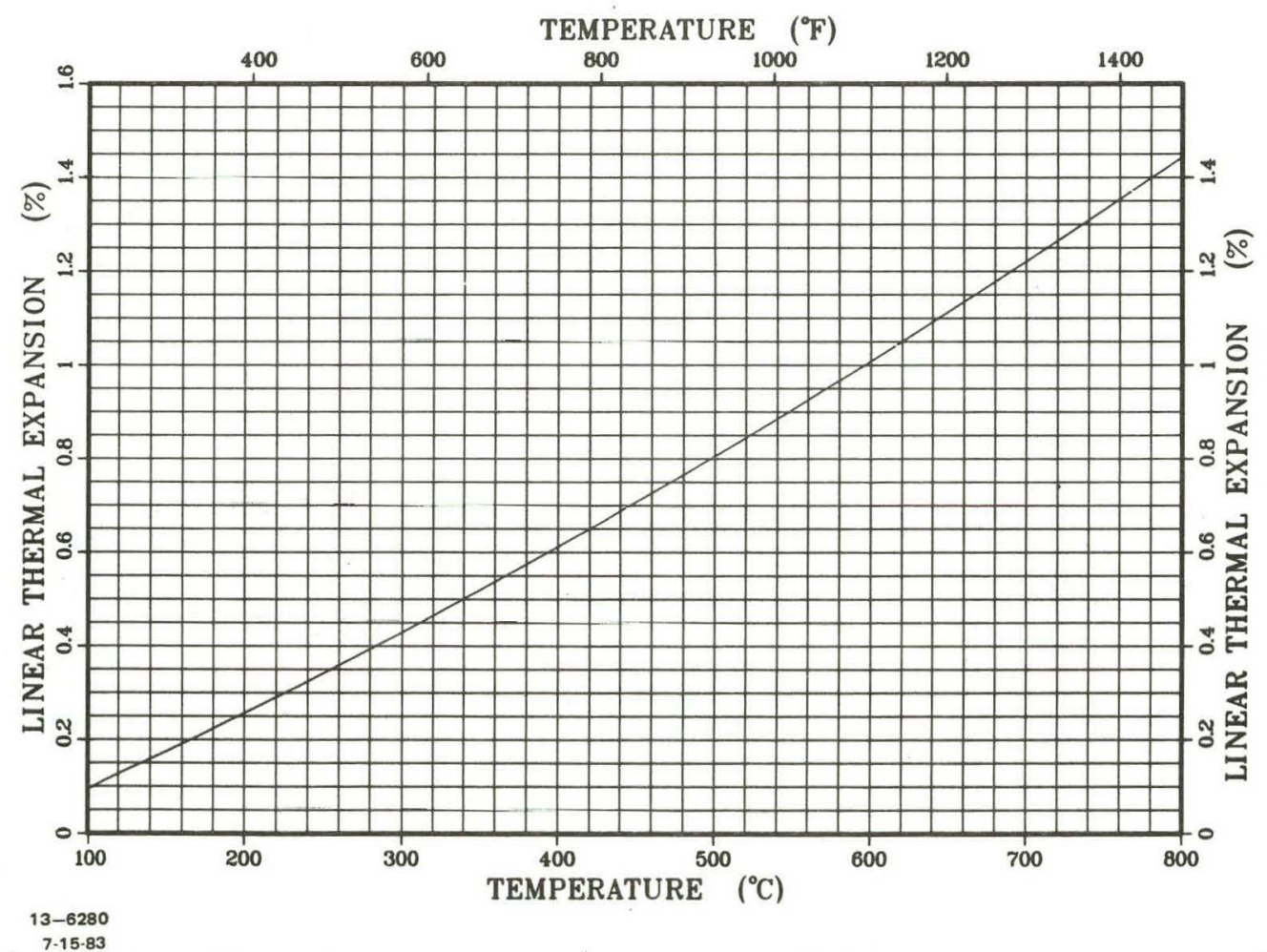

Figure 4.6.4.1 Linear Thermal Expansion of Polycrystalline Li2TiO3

\section{$4.6 .5 \frac{\mathrm{Li}_{2} \mathrm{O}-\mathrm{ZrO}_{2} \text { SYSTEM }}{2}$}

Hollenberg ${ }^{(26)}$ used a Theta Dilatometer with a Pt standard to measure the thermal expansion of $\mathrm{Li}_{2} \mathrm{ZrO}_{3}$. The hot pressed sample was 85\% TD with an average grain size of $2 \mu \mathrm{m}$. He verified it as being single phase by $x$-ray 
diffraction and chemical analysis, which revealed < $2000 \mu \mathrm{g} /$ total metallic impurities. His curve has been reproduced in Figure 4.6.5.1 with

$$
\operatorname{LTE}(\%)=-4.293 \times 10^{-4}+9.917 \times 10^{-4} \mathrm{~T}
$$

being valid from $100^{\circ}$ to $900^{\circ} \mathrm{C}$.

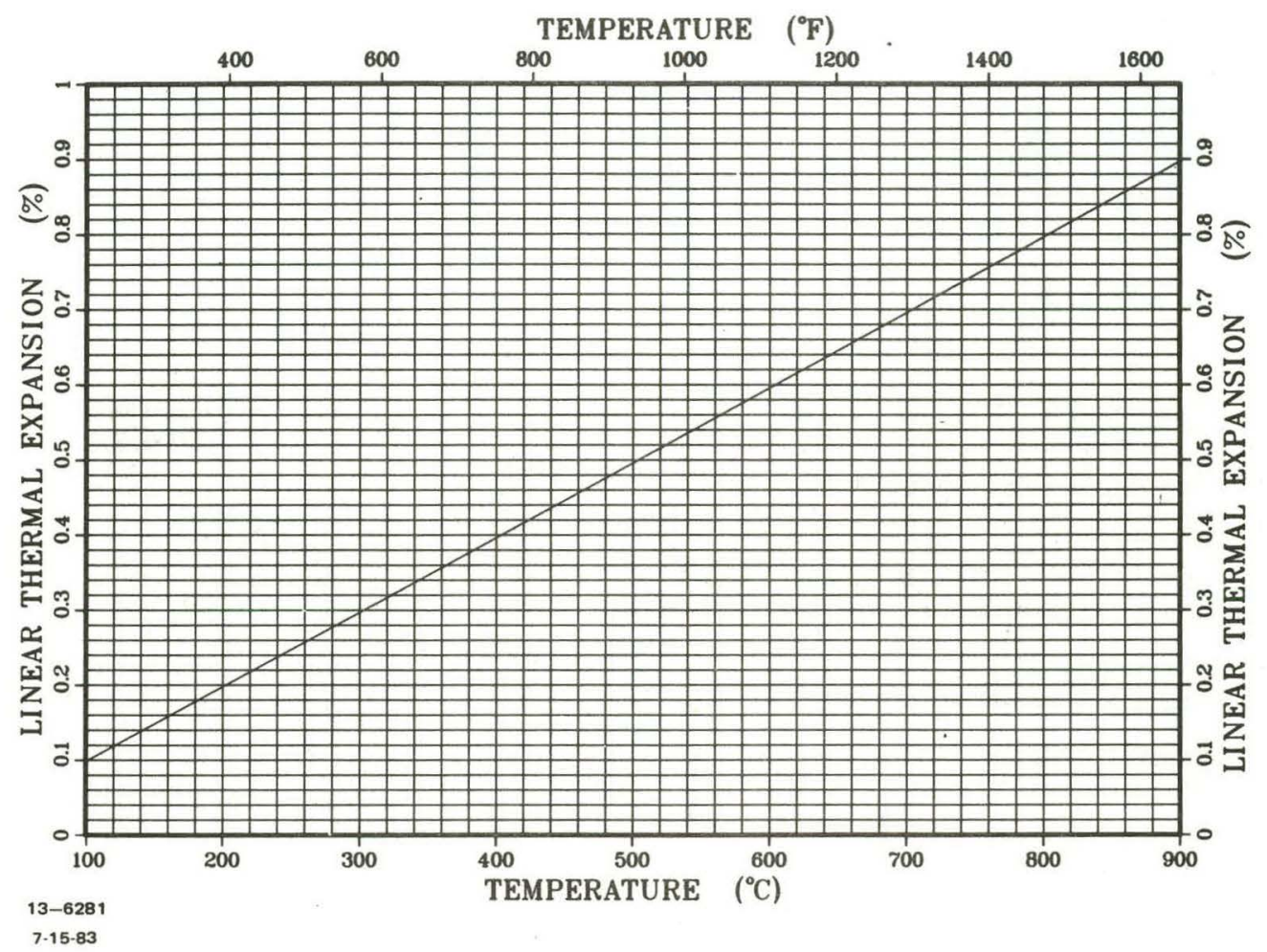

Figure 4.6.5.1 Linear Thermal Expansion of Polycrystalline $\mathrm{Li}_{2} \mathrm{ZrO}_{3}$

\subsection{6 $\mathrm{Li}_{2} 0-$ METAL OXIDE SYSTEMS}

A comparison of LTE (\%) of the various materials has been illustrated in Figure 4.6.6.1 with $\mathrm{Li}_{2} \mathrm{O}$ and $\mathrm{Li}_{4} \mathrm{SiO}_{4}$ showing the highest values. $\mathrm{Li}_{2} \mathrm{TiO}_{3}$ appears to be in the middle ground with $\mathrm{\gamma}-\mathrm{LiAlO}_{2}, \mathrm{Li}_{2} \mathrm{SiO}_{3}$, and $\mathrm{Li}_{2} \mathrm{ZrO} \mathrm{O}_{3}$ being closely bunched. 


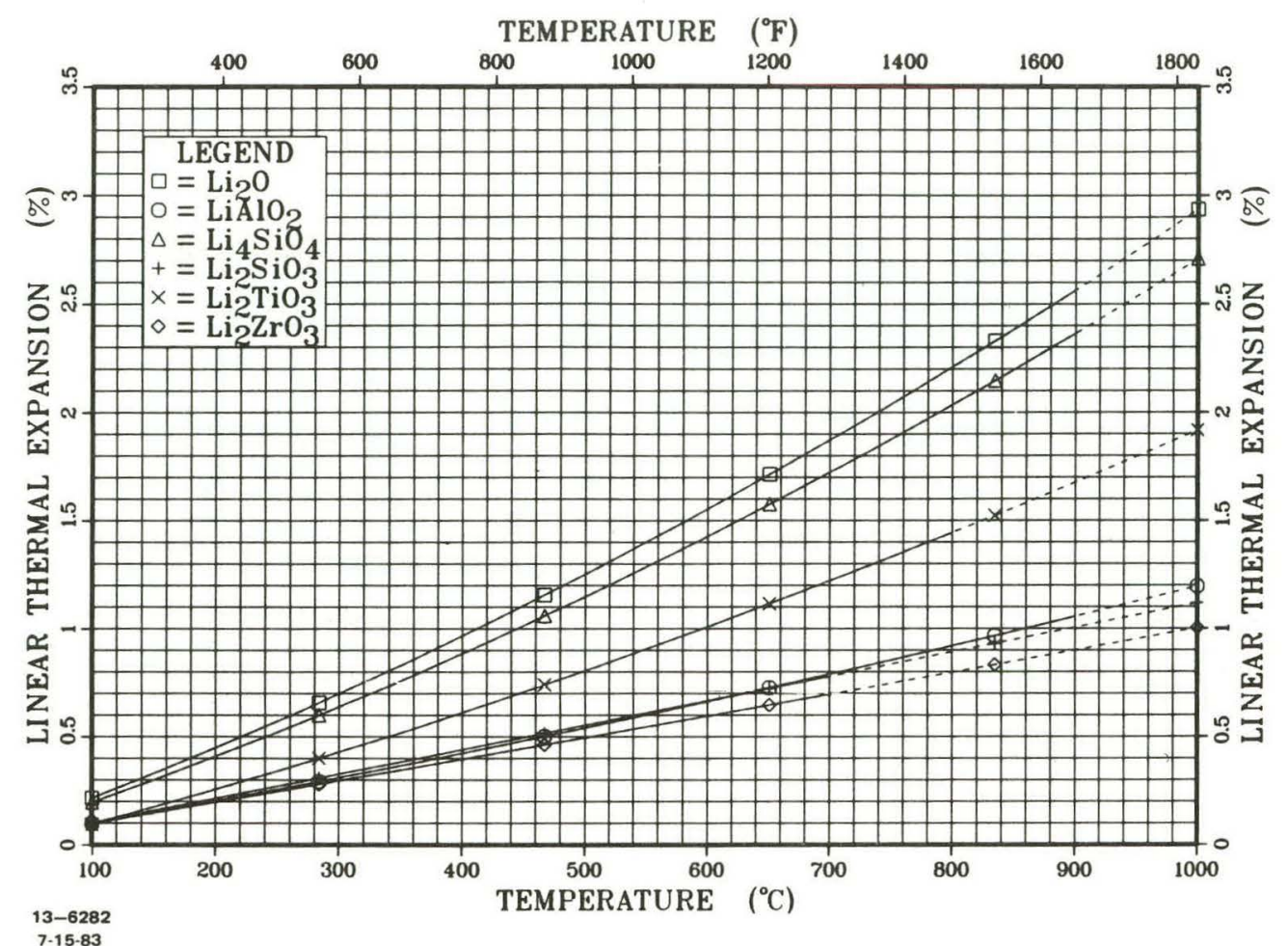

Figure 4.6.6.1 Comparison of Linear Thermal Expansion of Solid Breeder Candicates

\subsection{MISCELLANEOUS}

\subsection{1 $\mathrm{Li}_{2} \mathrm{O}$}

$$
\begin{aligned}
& \Delta H_{f}^{\circ}, 298.15 \mathrm{~K}=-142.57 \mathrm{kcal} / \mathrm{mole} \\
& \Delta \mathrm{H}_{\mathrm{m}} \quad=14 \mathrm{kcal} / \mathrm{mole} \\
& \mathrm{S}_{298.15 \mathrm{~K}}^{\circ}=9.056 \mathrm{cal} / \mathrm{deg}-\mathrm{mole} \\
& \text { (Ref. 29) } \\
& \text { (Ref. 40) } \\
& \text { (Ref. 40) } \\
& \mathrm{S}_{\mathrm{T}}^{\circ}-\mathrm{S}_{298.15 \mathrm{~K}}^{\circ}=(\mathrm{cal} / \mathrm{mole}-\mathrm{K})=-1.538 \times 10^{1}+6.157 \times 10^{-2} \mathrm{~T} \\
& -3.680 \times 10^{-5} \mathrm{~T}^{2}+1,107 \times 10^{-8} \mathrm{~T}^{3} \\
& \text { for } T=300-1400 \mathrm{~K} \\
& \text { (Ref. 30) } \\
& \mathrm{H}_{\mathrm{T}}^{\circ}-\mathrm{H}_{298.15 \mathrm{~K}}^{\circ}(\mathrm{cal} / \mathrm{mole})=-3.124 \times 10^{3}+7.467 \mathrm{~T}+ \\
& 1.091 \times 10^{-2} \mathrm{~T}^{2}-2.819 \times 10^{-6} \mathrm{~T}^{3} \\
& \text { for } T=300-1400 \mathrm{~K} \\
& \text { (Ref. 30) }
\end{aligned}
$$




$$
\begin{aligned}
& -\left(G_{T}^{\circ}-H_{298.15 \mathrm{~K}}^{\circ}\right) / \mathrm{T}(\mathrm{cal} / \mathrm{mole}-\mathrm{K})=8.389-4.443 \times 10^{-3} \mathrm{~T} \\
& +2.180 \times 10^{-5} \mathrm{~T}^{2}-8.488 \times 10^{-9} \mathrm{~T}^{3} \\
& \quad \text { for } \mathrm{T}=300-1400 \mathrm{~K}
\end{aligned}
$$

\section{$4.7 .2 \stackrel{\mathrm{Li}_{2} \mathrm{O}-\mathrm{Al}_{2} \mathrm{O}_{3} \text { SYSTEM }}{\text { ST }}$}

\subsubsection{1 $\mathrm{B}-\mathrm{Li}_{5} \mathrm{AlO}_{4}$}

$$
\Delta H_{f}^{\circ}, 298.15 \mathrm{~K}=-4 \mathrm{kcal} / \mathrm{mole}
$$

4.7.2.2 $\gamma-\mathrm{LiAlO}_{2}$

$$
\begin{aligned}
& \Delta H_{f}^{\circ} 298.15 \mathrm{~K}=284 \mathrm{kcal} / \mathrm{mole} \\
& \Delta H_{\mathrm{m}} \quad=21 \mathrm{kcal} / \mathrm{mole}
\end{aligned}
$$

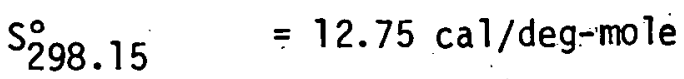

$$
\begin{aligned}
& \mathrm{S}_{\mathrm{T}}^{\circ}-\mathrm{S}_{298.15 \mathrm{~K}}^{\circ}=(\mathrm{cal} / \mathrm{mole}-\mathrm{K})=-1.972 \times 10^{1}+7.836 \times 10^{-2} \mathrm{~T} \\
& -4.445 \times 10^{-5} T^{2}+1.143 \times 10^{-8} T^{3} \\
& \text { for } T=300-1400 K \\
& H_{\mathrm{T}}^{\circ}-\mathrm{H}_{298.15 \mathrm{~K}}^{\circ}(\mathrm{kcal} / \mathrm{mole} \mathrm{e})=-4.161+1.028 \times 10^{-2} \mathrm{~T} \\
& +1.358 \times 10^{-5} \mathrm{~T}^{2}+4.219 \times 10^{-9} \mathrm{~T}^{3} \\
& \text { for } T=300-1400 \mathrm{~K} \\
& \text { - }\left(G_{T}^{\circ}-H_{298.15}^{\circ}\right) / T(\text { cal } / \text { mole }-K)=1.159 \times 10^{1}-2.789 \times 10^{-3} T \\
& +2.342 \times 10^{-5} T^{2}-9.165 \times 10^{-9} T^{3}
\end{aligned}
$$$$
\text { (Ref. 40) }
$$

\subsubsection{3 $\quad \operatorname{LiAl}_{5}{ }_{5} 8$}

$$
\Delta H_{f, 298.15 K}^{o}=-40 \mathrm{kcal} / \mathrm{mole}
$$




\subsection{3 $\mathrm{Li}_{2} \mathrm{O}-\mathrm{SiO} \mathrm{O}_{2}$ SYSTEM:}

4.7.3.1 $\mathrm{Li}_{4} \mathrm{SiO}_{4}$

$$
\begin{gathered}
\Delta H_{\mathrm{f}, 298.15 \mathrm{~K}}^{\circ}=-536 \mathrm{kcal} / \mathrm{mole} \\
\mathrm{S}_{298.15 \mathrm{~K}}^{\circ}=4.8 \mathrm{cal} / \mathrm{deg}-\mathrm{mole}
\end{gathered}
$$

$4: 7.3 .2 \cdot \mathrm{Li}_{2} \mathrm{SiO}_{3}$

$$
\begin{aligned}
& \Delta H_{f}^{\circ}, 298.15 \mathrm{~K}=-394 \mathrm{kcal} / \mathrm{mole} \\
& \Delta H_{\mathrm{m}}^{\circ}=6.7 \mathrm{kcal} / \mathrm{mole} \\
& \mathrm{S}_{298.15 \mathrm{~K}}^{\circ}=19 \mathrm{cal} / \mathrm{deg} \cdot \mathrm{mole} \\
& S_{T}^{\circ}-S_{298.15 \mathrm{~K}}^{0}(\text { cal } / \mathrm{K}-\mathrm{mole})=-2.893 \times 10^{1}+1.149 \times 10^{-1} \mathrm{~T} \\
& -6.501 \times 10^{-5} \mathrm{~T}^{2}+1.750 \times 10^{-8} \mathrm{~T}^{3} \\
& \mathrm{H}_{\mathrm{T}}^{\circ}-\mathrm{H}_{298.15 \mathrm{~K}}^{\circ}(\mathrm{kcal} / \mathrm{mole} \mathrm{e})=-5.768+1.301 \times 10^{-2} \mathrm{~T} \\
& +2.339 \times 10^{-5} \mathrm{~T}^{2}-7.293 \times 10^{-9} \mathrm{~T}^{3} \\
& \text { for } T=300-1250 k \\
& -\left(G_{T}^{\circ}-H_{298.15 K}^{\circ}\right) / \mathrm{T}(\mathrm{cal} / \mathrm{mole}-\mathrm{K})=1.868 \times 10^{1} \\
& -1.108 \times 10^{-2} T+4.543 \times 10^{-5} T^{2} \\
& -1.850 \times 10^{-8} T^{3} \\
& \text { for } T_{\ldots}=300-1250 \mathrm{~K}
\end{aligned}
$$$$
\text { (Ref. } 34,40 \text { ) }
$$

4.7.3.3 $\mathrm{Li}_{2} \mathrm{Si}_{2} \mathrm{O}_{5}$

$$
\begin{aligned}
& \Delta H_{\mathrm{f}, 298.15 \mathrm{~K}}^{\circ}=-612 \mathrm{kcal} / \mathrm{mole} \\
& S_{298.15 \mathrm{~K}}^{\circ}=29.20 \mathrm{cal} / \mathrm{deg}-\mathrm{mole}
\end{aligned}
$$




$$
\begin{aligned}
& S_{T}^{\circ}-S_{298.15 K}^{\circ}(\mathrm{cal} / \mathrm{mole}-\mathrm{K})=-4.144 \times 10^{1}+1.638 \times 10^{-1} \mathrm{~T} \\
& -9.058 \times 10^{-5} T^{2}+2.420 \times 10^{-8} T^{3} \\
& \text { for } T=300-1250 \mathrm{~K} \\
& H_{T}^{o}-H_{298.15 \mathrm{~K}}^{\circ}(\mathrm{kcal} / \mathrm{mole})=-8.191+1.802 \times 10^{-2} \mathrm{~T} \\
& +3.479 \times 10^{-5} T^{2}-1.051 \times 10^{-8} T^{3} \\
& \text { for } T=300-1250 \mathrm{~K}
\end{aligned}
$$

\section{$4.7 .4 \mathrm{Li}_{2} \mathrm{O}-\mathrm{TiO}_{2}$ SYSTEM}

4.7.4.1 $\mathrm{Li}_{2} \mathrm{TiO}_{3}$

$$
\begin{aligned}
& \Delta H_{f, 298.15 K}^{o}=-399.3 \mathrm{kcal} / \mathrm{mole} \\
& \Delta \mathrm{H}_{\mathrm{m}} \quad=26 \mathrm{kcal} / \mathrm{mole} \\
& \Delta \mathrm{S}_{298.15 \mathrm{~K}}^{\circ}=22 \mathrm{cal} / \mathrm{deg} \mathrm{mole} \\
& \mathrm{S}_{\mathrm{T}}^{0}-\mathrm{S}_{298.15 \mathrm{~K}}^{0}(\mathrm{cal} / \mathrm{mole}-\mathrm{K})=-3.163 \times 1.0^{1}+1.272 \times 10^{-1} \mathrm{~T} \\
& -7.670 \times 10^{-5} T^{2}+2.052 \times 10^{-8} T^{3} \\
& \text { for } T=300-1400 \mathrm{~K} \\
& \mathrm{H}_{\mathrm{T}}^{\circ}-\mathrm{H}_{298.15 \mathrm{~K}}^{\circ}(\mathrm{kcal} / \mathrm{mole})=-6.919+1.842 \times 10^{-2} \mathrm{~T} \\
& +1.769 \times 10^{-5} \mathrm{~T}^{2}-5.518 \times 10^{-9} \cdot \mathrm{T}^{3} \\
& \text { for } T=300-1400 \mathrm{~K} \\
& -\left(G_{T}^{\circ}-H_{298.15 K}^{\circ}\right) / T(\text { cal } / \text { mole-K })=1.983 \times 10^{1}-2.874 \times 10^{3} \mathrm{~T} \\
& +3.468 \times 10^{-5} \mathrm{~T}^{2}-1.371 \times 10^{-8} \mathrm{~T}^{3} \\
& \text { for } T=300-1400 \mathrm{~K}
\end{aligned}
$$




\section{$4.7 .5 \mathrm{Li}_{2} \mathrm{O}-\mathrm{ZrO}_{2}$ SYSTEM}

4.7.5.1 $\mathrm{Li}_{8} \mathrm{ZrO}_{6}$

$$
H_{f}^{\circ}, 298.15 \mathrm{~K}-852 \mathrm{kcal} / \mathrm{mole}
$$

4.7.5.2 $\mathrm{Li}_{4} \mathrm{ZrO}_{4}$

$$
H_{f, 298.15 \mathrm{~K}}^{\circ}=-565 \mathrm{kcal} / \mathrm{mole}
$$

$4.7 .5 .3 \cdot \mathrm{Li}_{2} \mathrm{ZrO}_{3}$

$$
\begin{aligned}
& \Delta H_{f}^{0}=-420 \mathrm{kcal} / \mathrm{mole} \\
& S_{298.15 \mathrm{~K}}^{\circ}=21.9 \mathrm{cal} / \mathrm{deg}-\mathrm{mole} \\
& \mathrm{S}_{\mathrm{T}}^{\circ}-\mathrm{S}_{298.15 \mathrm{~K}}^{\circ}=(\mathrm{cal} / \mathrm{mole}-\mathrm{K})=-3.172 \times 10^{1}+1.273 \times 10^{-1} \mathrm{~T} \\
& -7.616 \times 10^{-5} \mathrm{~T}^{2}+2.079 \times 10^{-8} \mathrm{~T}^{3} \\
& \text { for } T=300-1400 \mathrm{~K} \\
& H_{\mathrm{T}}^{\mathrm{o}}-\mathrm{H}_{298.15 \mathrm{~K}}^{\circ}=(\mathrm{kcal} / \mathrm{mole})=-6.946+1.857 \times 10^{-2} \mathrm{~T} \\
& +1.727 \times 10^{-5} \mathrm{~T}^{2}-4.626 \times 10^{-9} \mathrm{~T}^{3} \\
& \text { for } T=300-1400 \mathrm{~K} \\
& -3.165 \times 10^{-3} \mathrm{~T}+3.523 \times 10^{-5} \mathrm{~T}^{2}-1.379 \times 10^{-8} \mathrm{~T}^{3} \\
& \text { for } T=300-1400 \mathrm{~K}
\end{aligned}
$$




\subsection{REFERENCES}

1. Jaeger, F. M. and Van Clooster, H. S., Proc. Royal Acad. Amsterdam 16, $857-865$ (1914).

2. Van Arkel, A. E., Flood, E. A., and Bright, N. F. H., Can. J. Chem., 31 1009-1019 (1953).

3. Brewer, L. and Margrave, J. J., Phys. Chem., 59, 421-425 (1955).

4. Pappin, G., Michaud, M., and Bovariz, R., C. R. Acad. Sci., Paris, Ser. C., 268, 1691-1693 (1969).

5. Akiyama, M., Ando, K., and 0ishi, Y., J. Nucl. Sci. Technol., 17, 154-157 (1980).

6. Larsen, E. M. and Ortman, M. S., University of Wisconsin, UWFDM-449, 1-29 (1982).

7. Samsonov, G. V. (ed.), The Oxide Handbook, IFI/Plenum, New York, p. 105 (1973).

8. Ikeda, Y., Ito, H., Matsumoto, G., and Nasu, S., Mass Spectroscopy, $27(4)$, 263-273 (1979).

9. Kudo, H., Wu, C. H., and Ihle, H. R., J. Nucl. Mater., 78, 380-389 (1978).

10. Hildenbrand, D. L., Hall, W. F., and Potter, N. D., J. Chem. Phys., $\underline{39}$ (2) 296-301 (1963).

11. Berkowitz, J., Chupka, W. A., Blue, G. D., and Margrave, J. L., J. Phys. Chem., $\underline{\text { 63 }}(5), 644-648$ (1959).

12. White, D., Seshadri, K. S., Dever, D. F., Mann, D. E., and Linevsky, M. J., J. Chem. Phys, $39(10), 2463-2473$ (1963). 
13. Arons, R. M., Poeppel, R. B., Tetenbaum, M., and Johnson, C. E., J. Nucl. Mater., 103-104, 573-578 (1981).

14. Ikeda, Y., Ito, H., Matsumoto, G., and Hayashi, H., J. Nucl. Mater., 97, 47-58 (1981).

15. Guggi; D., Ihie, H. R., and Neubert; A., Proc. 9th Symposium on Fusion Technology, Garmisch-Partenkirchen (FRG), Pergamon Press, pp. 635-644 (1976):

16. Hildenbrand, D. L., J. Chem. Phys., 57(11), 4556-4560 (1972).

17. Popkov, 0. S. and Semenov, G. A., Zhurn. Fiz. Khim., 45 (2) 476-477 (1971).

18. Guggi, D., Neubert, A., Zmbov, K. F., Proc. 4th Int. Conf : on Chem. Thermo., J. Roquerol and R. Sabbah. (ed..), Cent.. Rech., Marsille, Vol. 3, pp. 124-131 $(1975)$

19. Nakagawa, H., Asano, M., and Kubo, K., J. Nuc1. Mater., 102, 292-297 (1981).

20. Neubert $A_{\text {. }}$, and Guggi, D., J. Chem. Thermo., 10, 297-306 (1978).

21... Ikeda, Y., Ito, H., Mizuno, T., and Matsumoto, G. ,. J. Nucl.o Mater. 105, 103-112: (1982).

22. Takeshita, H., Ohmichi, T., Nasu, S., Watanabe, H., Sasyama, T., Miyake, M., and Sano, T., J. Nuc1: Mater., 78, 281-288 (1978).

23. Omichi, T., Takeshita, H., Nasu, S., Sasayama, T., Maeda, A., Miyake, M., and Sano, T., J. Nucl. Mater. 82., 214-219 (1979).

24. Takahashi, T. and Kikuchi, T., J. Nucl. Mater., 91; 93-102 (1980).

25. Shomate, H. and Cohen, A. J., J. Am. Chem. Soc., 77, 285-286 (1955). 
26. Hollenberg, G. W., "Thermal Properties of Lithium Ceramics for Fusion Applications", presented at the 84 th Annual Meeting of the Am. Cer. Soc., Cincinnati, Ohio, May 3-5, 1982.

27. Gurwe11, W. E., Battelle Pacific Northwest Laboratory, BNWL-CC-464, $1-21$ (1966).

28. Finn, P. A., Kurasawa, T., Nau, S., Noda, K., and Watanabe, H., 9th Symposium on Engineering Problems of Fusion Research, IEEE No. 81CH1715-2, Vol. II, 1200-1204 (1981).

29. Johnston, H. L., and Bauer, T. W., J. Am. Chem. Soc., 73, 1119-1122 (1951).

30. Tanifuji, T., Shiozawa, K. and Nasu, S., J. Nucl. Mater., 78 422-424 (1978).

31. Barin, I., and Knacke, 0., Thermochemical Properties of Inorganic Substances, Springer-Verlag, Berlin, p. 416 (1973).

32. Rodigina, E. N. and Gomelskii, K. Z., Russ. J. Phys. Chem., 35, 898-901 (1961).

33. Christensen, A. U., Conway, K. C.: and Kelby, K. K., U. S. Bureau Mines, RI-5565, 1-7 (1960).

34. Bennington, K. 0., Ferrante, M. J., and Stuve, J. M., U. S. Bureau Mines, RI-8187, 1-19 (1976).

35. Kurasawa, T., Takahashi, T., Noda, K., Kakeshita, H., Nasu, S., and Watanabe, H., J. Nucl. Mater., 107, 334-336 (1982).

36. Humme 1, F. A., J. Am. Cer. Soc., 34(8), 235-239 (1951).

37. Soga, N., J. Am. Cer. Soc., 47, 468-469 (1964).

38. Kirchner, H. P., Merz, K. M., and Smyth, H. T., U. S. Bureau Ordinance, CAL-PI-1273-M-4, Vol. 2, 1-43 (1959). 
LITHIUM BASED OXIDE CERAMICS FOR TRITIUM BREEOING APPLICATIONS

Report MDC E2677

39. Girard, R. T., Sims, C. T., and Wisely, H. R., General Electric Company, U. S. Patent \#3, 397, 080 (1968).

40. JANAF Thermochemical Tables, National Bureau of Standards, NSRDS-NBS-37, (1.971).

41. Aronson, S., J. Nucl. Mater., 107, 343-346 (1982.).

42. Lithium Corporation of America Product Bulletin on $\mathrm{Li}_{4} \mathrm{SiO}_{4}$, Bessemer City, N.J., 28016.

43. King, E. G., J. Am. Chem. Soc., 77, 2150-2152 (1955).

MCDONNELL DOUGLAS ASTAONAUTICS COMPANY ST LOUIS OIVISION 


\subsection{COMPATIBILITY OF LITHIUM CERAMICS AND METALS}

\subsection{INTRODUCTION}

Since solid breeding materials will be in contact with metal structure and coolant tubes during a blanket's operating temperatures, any interactions must be considered. One concern centers on the migration of "active" portions of the solid breeder and/or metal to the interface and its subsequent reaction or scale formation. Depending upon the amount or type of attack, the reaction layer could lead to chemical or stress corrosion and eventual cracking of the metal. In addition, any interaction could result in a two-phase layer within the solid breeder itself which might possess low temperature liquid phases.

\subsection{Li-O SYSTEM}

Takeshita et al. (1) studied the reaction between an $\mathrm{Li}_{2} \mathrm{O} 88 \%$ TD pellet and Mo or molybdenum-base alloy TZM - (Titanium-Zirconium-Molybdenum) discs. The sample surfaces were initially electrolytically polished so that intimate contact could be assured. Then the reaction couples were stacked in a 316 SS cylinder and heated in a resistance furnace from $800^{\circ}-1100^{\circ} \mathrm{C}$ for 100 hours under a dynamic vacuum of $10^{-5}$ torr. Their results (1isted in Figure 5.2.1) indicate very little interaction between $\mathrm{Li}_{2} \mathrm{O}$ and Mo (sintered) or Mo (EBM - Electron Beam Melted) below $1000^{\circ} \mathrm{C}$ and with TZM below $950^{\circ} \mathrm{C}$. Very little physical change in either the ceramic or metals was observed below these temperatures. However, at or above these temperatures a black reaction layer was observed on all three metallic samples, and this layer was identified by $x$-ray diffraction to be $\alpha-\mathrm{Li}_{4} \mathrm{ifOO}_{5}$. In addition, at the higher temperatures another layer was observed but its pattern did not correspond to any compound known in the $\mathrm{Li}_{2} \mathrm{O}-\mathrm{Mo}$ system. The authors did not report any changes in the $\mathrm{Li}_{2} \mathrm{O}$ samples other than the loss of surface $\mathrm{Li}_{2} \mathrm{O}$ required to form $\mathrm{Li}_{4} \mathrm{MoO}_{5}$ on the metal surface.

Most of the compatibility studies $(2,3,5)$ have centered on the use of $\mathrm{Li}_{2} \mathrm{O}$ with the $\mathrm{Fe}-\mathrm{Ni}-\mathrm{Cr}$ alloys such as 316 stainless steel (SS), Incoloy 800, Hastelloy $\mathrm{X}-\mathrm{R}$, Inconel 600, HT-9, a $\mathrm{Ni}$ coated $316 \mathrm{SS}$, and pure $\mathrm{Ni}$. The studies were 
FIGURE 5.2.1 LITHIA/METAL COMPATIBILITY RESULTS

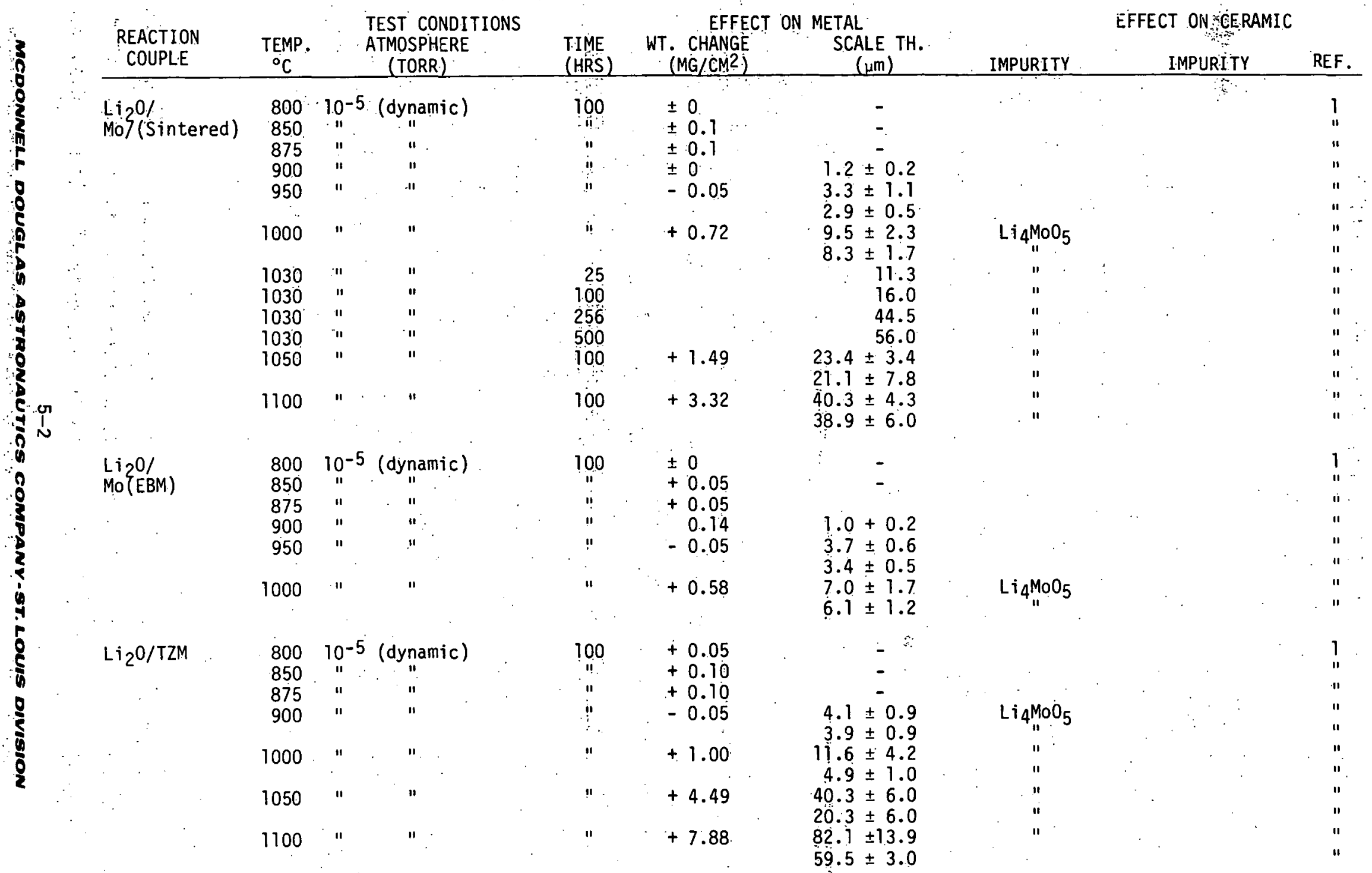


FIGURE 5.2.1 LITHIA/METAL COMPATIBILITY RESULTS

(CONTINUED)

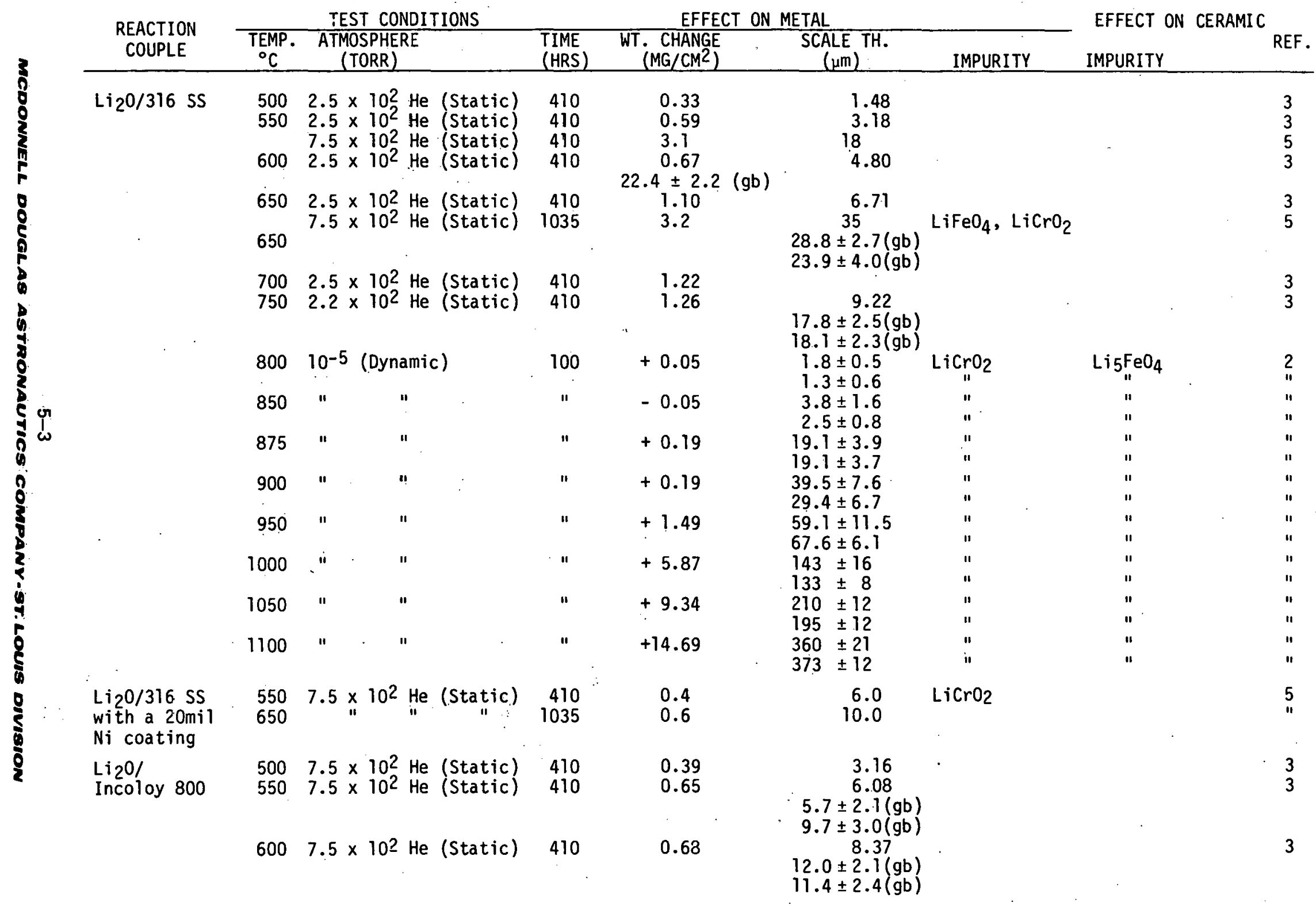


FIGURE 5.2.1 LITHIA/METAL COMPATIBILITY. RESULTS

(CONTINUED)

EEFFECT ON METAL

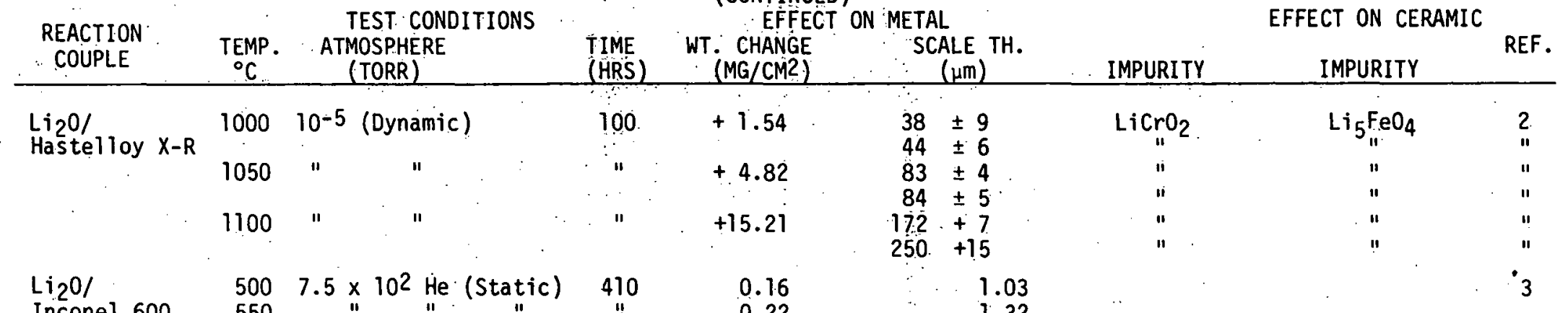

Inconel 600

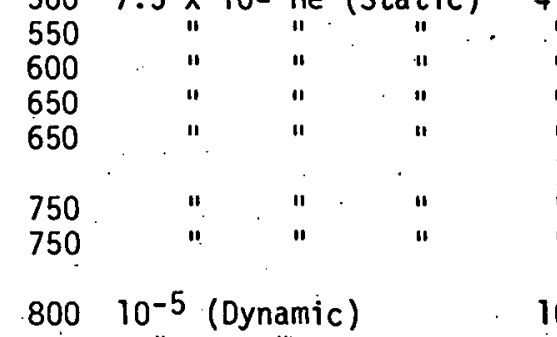

0.22

1.32

0.45

0.62

3.27

$9.8 \pm 0.9(\mathrm{gb})$

$8.9 \pm 0.8(\mathrm{gb})$
3.30

0.89

800

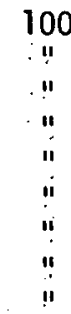

$21.6 \pm 5.9(\mathrm{gb})$

$18.4 \pm 4.2(\mathrm{gb})$

$6.0 \pm 2.7$

$6.1 \pm 2.4$

$19.5 \pm 6.6(\mathrm{gb})$

$19.6 \pm 5.7(\mathrm{gb})$

850

$+1.37$

$13.1 \pm 3.8$

$44.5 \pm 13.1$ (gb)

$44.0 \pm 9.9(\mathrm{gb})$

875

$+2.62$

$20.9 \pm 2.4$

$26.6 \pm 6.8$

$49.6 \pm 7.9(\mathrm{gb})$

$54.5 \pm 3.3(\mathrm{gb})$

900

$+2.37$

$33.8 \pm 5.5$

$21.2 \pm 5.3$

950

$+5.81$

$56.8 \pm 16.1$

$122.6 \pm 25.9$

1000

$+7.99$

$.3 \pm 22.1(\mathrm{gb})$

$109 \pm 7$ 
FIGURE 5.2.1 LITHIA/METAL COMPATIBILITY RESULTS

(CONTINUED)

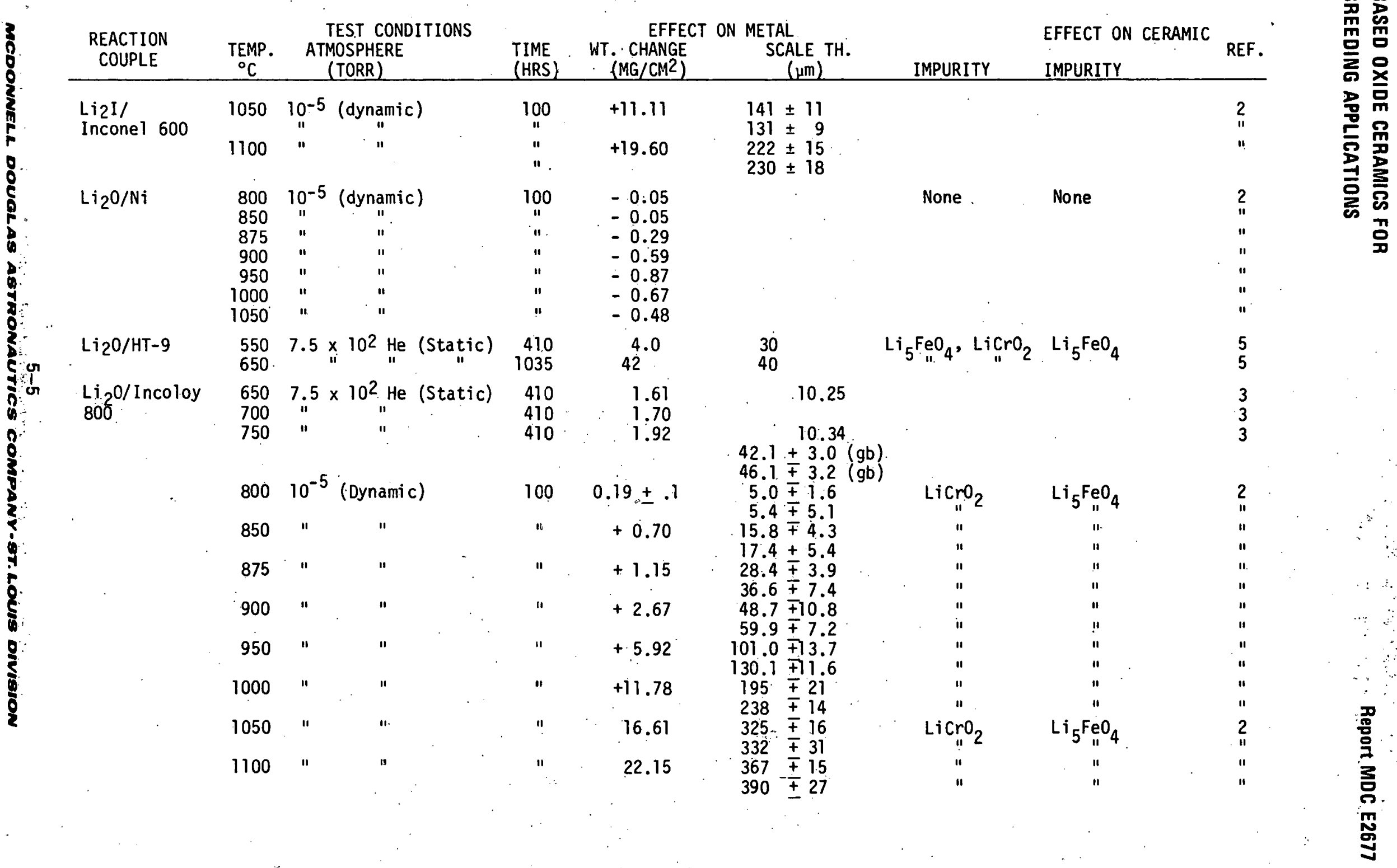


FIGURE 5.2.1 LITHIA/METAL COMPATIBILITY RESULTS

(CONTINUED)

EFFECT ON METAL.

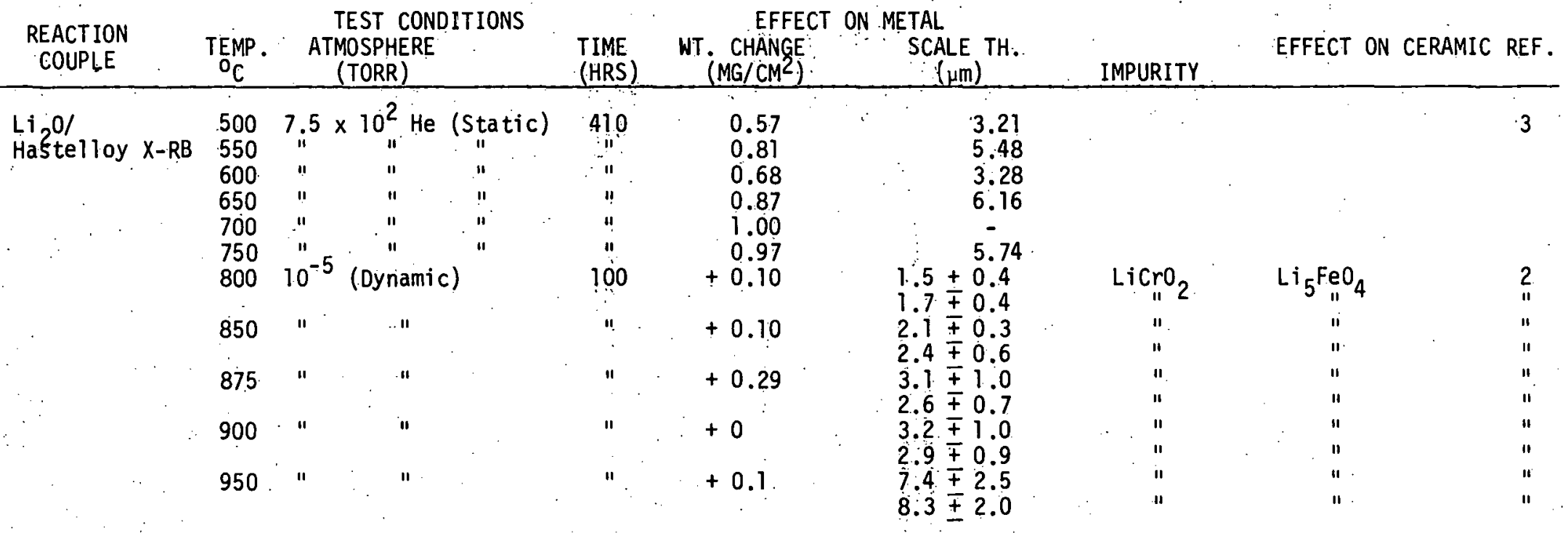


conducted from $500^{\circ}-1100^{\circ} \mathrm{C}$, in vacuum or He atmospheres, and for various lengths of times, 100-1035 hours. The results are listed in Figure 5.2.1 and of these only pure $\mathrm{Ni}$ appears to be relatively inert when in contact with $\mathrm{Li}_{2} \mathrm{O}$. The metal compositions have been outlined in Figure 5.2.4. The $316 \mathrm{SS}$ starts to react severely after $950^{\circ} \mathrm{C}$, al though there is grain boundary attack at $600^{\circ} \mathrm{C}$. The metal samples tested at temperatures of $950^{\circ}-1100^{\circ} \mathrm{C}$ revealed significant weight gain $(\Delta W)$ and oxide scale formation (identified as $L i C r O_{2}$ ), while $\mathrm{Li}_{5} \mathrm{FeO}_{4}$ appeared on the $\mathrm{Li}_{2} \mathrm{O}$ surface. A $20 \mathrm{mil}$ vapor-deposited $\mathrm{Ni}$ coating on the 316 SS lowered both the metal's weight gain and oxide scale formation $\left(\mathrm{LiCrO}_{2}\right)$ and prevented the appearance of any $\mathrm{Li}_{5} \mathrm{FeO}_{4}$ on the $\mathrm{Li}_{2} 0$ surface. The $\mathrm{Ni}$ coating together with the $\mathrm{LiCrO}_{2}$ formation was thought to play a role in inhibiting the Fe diffusion to the $\mathrm{Li}_{2} \mathrm{O}$ surface.

The $\mathrm{Li}_{2}$ O/Incoloy 800 couple showed significant scale formation $(15 \mu \mathrm{m})$ o $850^{\circ} \mathrm{C}$ and again revealed $\mathrm{LiCrO}_{2}$ on the metal and $\mathrm{Li}_{5} \mathrm{FeO}_{4}$ on the surface of $\mathrm{Li}_{2} \mathrm{O}$. At $100^{\circ} \mathrm{C}$, the weight gain of the metal is twice that of 316 SS but the oxide scale was only $50 \%$ greater. At the lower temperatures, especially in stagnant $\mathrm{He}$, there is not too much change in weight between the Incoloy 800 and the 316 SS but the oxide scale was only $50 \%$ greater. At the lower temperatures, especially in stagnant He, there is not too much change in weight between the Incoloy 800 and the 316 SS but there is twice as much grain boundary attack in the Incoloy 800 .

The $\mathrm{Li}_{2} \mathrm{O}$ with Hastelloy $\mathrm{X}-\mathrm{R}$ lasted until $1000^{\circ} \mathrm{C}$ under vacuum before succumbing to marked attack. However, even at the higher temperatures it is $1 / 3-1 / 2$ the amount of reaction of the $316 \mathrm{SS}$; this difference is probably due to its higher $\mathrm{Ni}$ content and lower Fe contents.

The $\mathrm{Li}_{2} \mathrm{O}$ /Inconel 600 couple did not show the expected improvement with increasing $\mathrm{Ni}$ content. Its results were slightly higher than those of the Hastelloy $X-R$ despite the increase in $\mathrm{Ni}$ and decrease in $\mathrm{Fe}$ contents with that of Inconel. Again $\mathrm{LiCrO}_{2}$ and $\mathrm{Li}_{5} \mathrm{FeO}_{4}$ were seen as the major contaminants at the high temperatures $\left(+800^{\circ} \mathrm{C}\right)$. 
The Li ${ }_{2}$ /HT-9 couple showed 4-5 times the reaction of the 316 . SS at higher temperatures in a static He environment. In addition, $\mathrm{Li}_{3} \mathrm{FeO}_{2}$ was also seen in the scale on the metal and not just on the cermaic surface as before.

Since oxide scale formation can be described by a parabolic function $\mathrm{w}^{2}=\mathrm{kt}$ (where $w^{2}=$ the weight change or oxide scale thickness, $t=$ reaction time, and $k=$ the rate constant), a plot of $k$ versus $1 / T$ was made (Figure 5.2.2). Since $\mathrm{Ni}$ interaction with $\mathrm{Li}_{2} \mathrm{O}$. was so minute, no data were available for the graph. The Mo alloys show the least oxide scale formation when compared to the $\mathrm{Fe}-\mathrm{Ni}-\mathrm{Cr}$ alloys, especially at low temperatures. Hastelloy $X-R$ is the best in comparison with 316 SS, Incoloy 800 , and Inconel 600 al though, at temperatures $\approx 800^{\circ} \mathrm{C}$, it approaches the same reactivity as $316 \mathrm{SS}$. The Incoloy 800 follows fairly closely the reactivity of 316 SS, while Inconel 600 behaves like Incoloy 800 at temperatures below $\approx 850^{\circ} \mathrm{C}$ and behaves 1 ike $316 \mathrm{SS}$ at higher temperatures. The results for the Hastelloy $X-R$ are attributed to the Mo addition which counters its higher Fe content compared to Inconel 600 . The data were generated (four couples) in a dynamic $10^{-5}$ vacuum, yet $\mathrm{Li}_{2} \mathrm{O}$ vaporization has not been addressed, especially at the higher temperatures $\left(>1000^{\circ} \mathrm{C}\right.$ ).

Figure 5.2 .3 is a similar plot for temperatures below $700^{\circ} \mathrm{C}$ and static He. The slope has radically changed for Hastelloy $X-R$, almost exhibiting no temperature dependence. At the lower temperatures, the inconel 600 performed better than the 316. SS, as would be expected with its low $\mathrm{Fe}$ and high $\mathrm{Ni}$ concentrations. The Incoloy 800 has maintained its previously seen relationship to 316 SS despite its compositional differences. Hastelloy $X-R$ is still the best of the $\mathrm{Fe}-\mathrm{Ni}-\mathrm{Cr}$ alloys because of its nonresponse to temperature, al though the $316 \mathrm{SS}$ provides better resistance to the $\mathrm{Li}_{2} \mathrm{O}$ at temperatures below $600^{\circ} \mathrm{C}$. Comparison of the data presented in both figures is difficult since atmosphere seems to play a big role in the diffusion kinetics. It is hard to imagine that the reactivity of the metal is any different under vacuum than $\mathrm{He}$, but the ceramic may be another matter. The presence of $\mathrm{LiOH}$ or $\mathrm{Li}_{2} \mathrm{CO}_{3}$ has been hypothesized as the reactive species instead of $\mathrm{Li}_{2} \mathrm{O}$ itself. In all the studies, the presence or lack of presence of these two compounds is not actively discussed. 


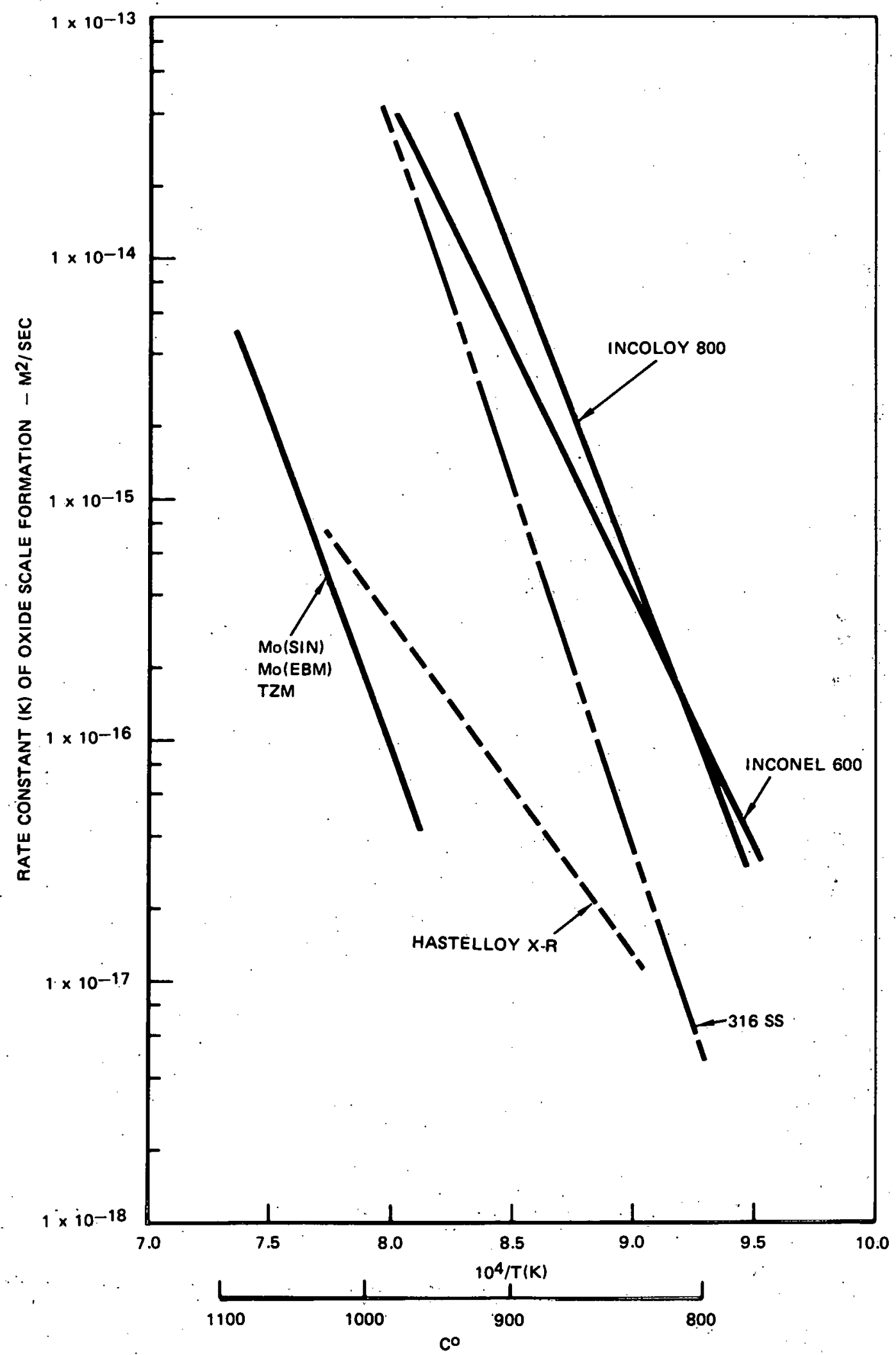

FIGURE 5.2.2 RATE OF OXIDE SCALE FÓRMATION ON METAL/Li, 2 O REACTION COUPLES IN A $\cdot 10^{-5}$ TORR ENVIRONMENT 


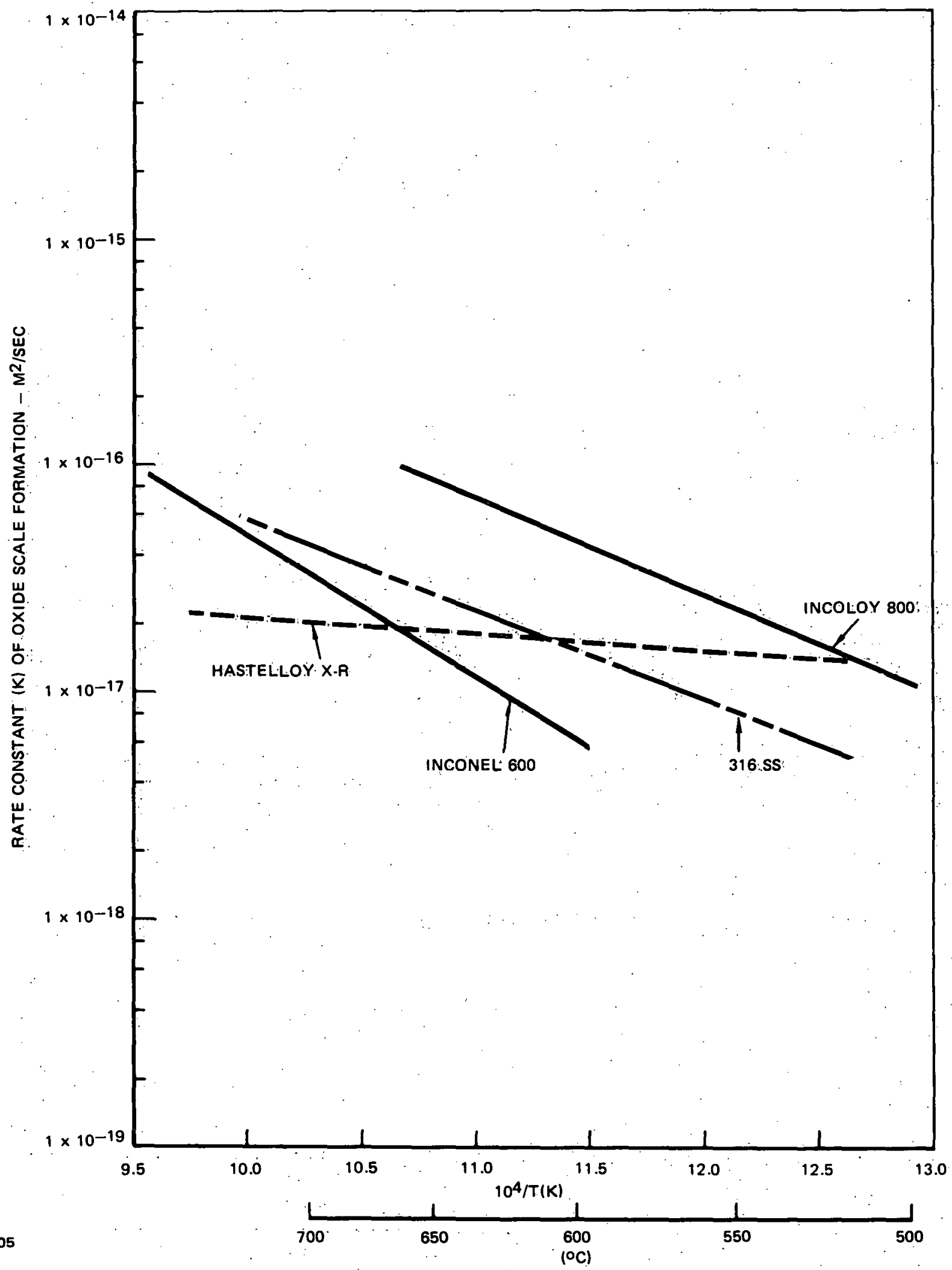

FIGURE 5:2.3 RATE OF OXIDE SCALE FORMATION ON METAL/Li 2 O REACTION COUPLES IN A STÁTIC HE ENVIRONMENT 
FIGURE 5.2.4 CHEMICAL COMPOSITIONS OF METAL REACTION COUPLE SPECIMENS (WT\%)

\begin{tabular}{|c|c|c|c|c|c|c|c|c|}
\hline & 316 SS & INCOLOY 800 & HASTEELLOY X-R & INCONEL 600 & $\mathrm{Ni}$ & Mo (sin) & Mo (EBM) & TZM \\
\hline $\begin{array}{l}\mathrm{Fe} \\
\mathrm{Ni}\end{array}$ & $\begin{array}{l}69.79 \\
10.14\end{array}$ & $\begin{array}{l}43.8 \\
33.2\end{array}$ & $\begin{array}{l}18.4 \\
49.5\end{array}$ & $\begin{array}{r}8.13 \\
74.96\end{array}$ & $\begin{array}{r}0.03 \\
99.56\end{array}$ & - & $\begin{array}{l}.0002 \\
.0001\end{array}$ & $\begin{array}{l}.002 \\
.001\end{array}$ \\
\hline $\mathrm{Cr}$ & 16.83 & 20.7 & 22.0 & 16.16 & - & - & 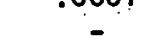 & - \\
\hline Mo & 2.10 & - & 8.81 & - & - & 99.8 & 99.95 & 99.83 \\
\hline Al & - & 0.04 & 0.02 & - & - & - & - & - \\
\hline$T i$ & - & 0.36 & 0.02 & - & - & - & - & .04 \\
\hline$M n$ & 0.72 & 0.9 & 0.65 . & 0.21 & 0.26 & - & - & - \\
\hline $\mathrm{Si}$ & 0.36 & 0.31 & 0.03 & 0.39 & 0.03 & - & .0066 & .001 \\
\hline $\mathbf{P}$ & 0.035 & - & - & 0.008 & - & - & - & - \\
\hline$S$ & 0.02 & 0.0005 & - & 0.002 & - & - & - & - \\
\hline C & 0.07 & 0.03 & 0.08 & 0.04 & 0.09 & .002 & .008 & .024 \\
\hline $\mathrm{Cu}$ & - & 0.21 & - & 0.02 & 0.03 & - & - & - \\
\hline 0 & - & - & - & - & - & - & .0005 & .0006 \\
\hline $\mathrm{Zr}$ & - & - & - & - & - & - & - & .092 \\
\hline
\end{tabular}




\section{$5.3 \quad \mathrm{Li}_{2} \mathrm{O}-\mathrm{Al}_{2} \mathrm{O}_{3}$ SYSTEM}

Hollenberg ${ }^{(4)}$ studied $\gamma-\mathrm{LiAlO}_{2}$ interactions with $316 \mathrm{SS}$. or $\mathrm{Ni} 270 \bigcirc 600^{\circ} \mathrm{C}$ for 98 days. In addition, he investigated $\gamma-\mathrm{LiAlO}_{2} / \mathrm{Ni} 270$ o $750^{\circ} \mathrm{C}$ for 98 days. In all three cases negligible interaction was detected. His samples were encapsulated in a stainless steel cup sealed in a dry inert gas atmosphere. Each sample was then heated individually by resistance heated furnaces, which maintained a constant temperature $\pm 10^{\circ} \mathrm{C}$.

\section{$5.4 \mathrm{Li}_{2}{ }^{\mathrm{O}-\mathrm{SiO}_{2}}$ SYSTEM}

Hollenberg ${ }^{(4)}$ used $\mathrm{Li}_{4} \mathrm{SiO}_{4} 85 \%$ TD and $\mathrm{Ni} 270$ or 316 SS $0600^{\circ} \mathrm{C}$ for 98 days and $\mathrm{Ni} 270$ at $750^{\circ} \mathrm{C}$ for 98 days. In a 11 three cases the $\mathrm{Li}_{4} \mathrm{SiO}_{4}$ pellets were sandwiched between either $\mathrm{Ni} 270$ or $316 \mathrm{SS}$ in a stainless steel cup and encapsulated in a dry inert gas atmosphere. The results of his study indicate that negligible interaction occurred between the $\mathrm{Li}_{4} \mathrm{SiO}_{4}$ and the two metals.

\subsection{L $\quad \mathrm{i}_{2} \mathrm{O}-\mathrm{TiO}_{2}$ SYSTEM}

Firin et al (5) formed a L ${ }_{2}{ }_{2} \mathrm{THO}_{3}$ lalloy coupled with HT-9, 316. SS, and Ni coated $(20 \mathrm{~m})$. $316 \mathrm{SS}$ and hea ted them to $650^{\circ} \mathrm{C}$ for 410 hours or $050^{\circ} \mathrm{C}$ for 1035 hours in $10^{5}$. Pa static helium atmosphere. They found that a slight amount of scale formed on all three metals, with the Ni coated 316 SS showing the most and HT-9 the least amount. In all three, $\mathrm{LiCrO}_{2}$ was the major and $\mathrm{LiFeO}_{2}$ the minor contaminant. They believed that the formation of significant amounts of $\mathrm{LiCrO}_{2}$ acted as a barrier to $\mathrm{LiFeO}_{2}$ formation. In any event, the amount of scale was $\approx 1 / 2$ that of the $\mathrm{Li}_{2} \mathrm{ZrO}_{3}$ couples, and 1/6 of the amount of penetration incurred using $\mathrm{Li}_{2} \mathrm{O}$ couples of the same three metals. Although no scale was formed on the $\mathrm{Li}_{2} \mathrm{TiO}_{3}$ samples, the $\mathrm{TiO}_{2}$ content on the surface increased, verifying the transport of lithium to form the scale on the metal.

\section{$5.6 \mathrm{Li}_{2} \mathrm{O}-\mathrm{ZrO}_{2}$ SYSTEM}

Finn and co-workers ${ }^{(5)}$ studied the reaction of $\mathrm{Li}_{2} \mathrm{ZrO}_{3}$ (88\% TD) with HT-9, $316 \mathrm{SS}$ and $\mathrm{Ni}$ coated 316 SS $(20 \mu \mathrm{m})$ substrates. The sandwich arrangements 
were held o $650^{\circ} \mathrm{C}$ for 410 hours or $550^{\circ} \mathrm{C}$ for 1035 hours in $\sim 10^{5}$ Pa static helium environment. Their results indicate severe interaction with the HT-9 metal, with the $\mathrm{Ni}$ coated 316 SS showing the least. The scale formed on the HT-9 was identified as $\mathrm{LiFeO}_{2}$ with a small amount of $\mathrm{LiCrO}_{2}$. The 316 SS aga in revealed $\mathrm{LiFeO}_{2}$ with a minor amount of $\mathrm{LiCrO}_{2}$. The $\mathrm{Ni}$ coated 316 SS showed the least amount of contamination, with $\mathrm{LiCrO}_{2}$ being the major contaminant identified and a minor amount of $\mathrm{LiFeO}_{2}$. Al though no scale was formed on the $\mathrm{Li}_{2} \mathrm{ZrO}_{3}$, the amount of $\mathrm{ZrO}_{2}$ was increased at the surface, corresponding to the loss of $\mathrm{Li}_{2} \mathrm{O}$ to form the scale on the metal.

Hollenberg ${ }^{(4)}$ encapsulated a $\mathrm{Li}_{2} \mathrm{ZrO}_{3}$ sample $75 \%$ To with $\mathrm{Ni}$ in a stainless steel cup sealed in a dry inert gas and heated in a resistance furnace for 98 days $0750^{\circ} \mathrm{C}$. He found no formation of any new phases on either surface and essentially no interaction.

\subsection{REFERENCES}

(1) Takeshita, H., Kurasawa, T., Muraoka, S., Nasu, S., Miyake, M., and Sano, T., J. Nucl. Mater., 80, 249-252 (197.9).

(2) ibid, $48-56$.

(3) Kurasawa, T., Takeshita, H. and Nasu, S., J. Nucl. Mater., 92, 67-72 (1980).

(4) Hollenberg, G. W., Hanford Engineering Development Laboratory, TC-2022 (1981).

(5) Finn, P. A., Kurasawa, T., Nasu, S., Noda, K., Takahashi, T., Takeshita, H., Tanifuju, T. and Watanabe, H., IEEE Pub. No. 81CH1715-2 NPS, 1200-1204 (1981). 
MCDONNELL DOUGLAS ASTRONAUTICS COMPANY-ST. LOUIS DIVISION

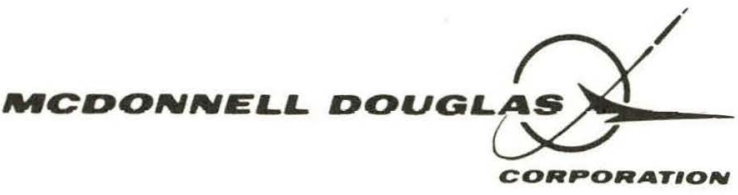

$$
\begin{aligned}
& \text { DO NOT MICROFILM } \\
& \text { THIS PAGE }
\end{aligned}
$$

